\title{
MARKET ORIENTATION AND SUCCESSFUL NEW PRODUCT INNOVATION: THE ROLE OF COMPETENCY TRAPS
}

\author{
Yinghong (Susan) Wei
}

A dissertation submitted to the faculty of the University of North Carolina at Chapel Hill in partial fulfillment of the requirements for the degree of Doctor of Philosophy at the Kenan-Flagler Business School

Chapel Hill

2006

Approved by

Advisor: Professor Hugh O’Neill

Reader: Professor Neil Morgan

Reader: Professor Bill Perreault

Reader: Professor Kwaku Atuahene-Gima

Reader: Professor Annette Ranft 
(C) 2006

Yinghong (Susan) Wei

ALL RIGHTS RESERVED 


\section{ABSTRACT \\ Yinghong (Susan) Wei: Market Orientation and Successful New Product \\ Innovation: The Role of Competency Traps \\ (under the direction of Hugh O'Neill)}

This study seeks to enhance understanding of successful new product innovation by developing and testing a new theory framework for explaining the market orientationproduct innovation relationship in the context of firms' new product development (NPD) processes. Drawing on and adapting key concepts from organizational learning theory, and particularly in the area of capability-rigidity theory, the study investigates how market orientation may create rigidity, known as competency traps, that reduce innovation performance.

Competency traps concern the propensity of a firm to continue relying on processes that have been successful in the past even though they are no longer optimal. Although the concept of competency traps was introduced in management literature more than a decade ago, it has been the focus of little conceptual development and no empirical research. Given the potential adverse consequences of competency traps in NPD, it is important that we understand the sources and impact of competency traps. This study develops an integrated conceptual framework to help researchers and managers identify and reduce the effect of competency traps on NPD. The development of a valid measure of competency traps should enable researchers and managers to better diagnose competency traps. Entrepreneurial 
orientation and network learning are suggested as the remedy to manage the possible adverse effects.

The study includes a major survey of the responses of 113 marketing managers from a high-technology industrial zone in China. Structural equation modeling and reliability tests are used for data analysis. Three types of competency traps are identified: (1) vision traps, (2) technology traps, and (3) routinization traps. The newly developed scales demonstrate reasonably good validity and reliability. The findings show that customer orientation leads to a routinization trap. However, routinization traps are positively associated with NPD creativity and NPD efficiency. Vision traps are negatively associated with NPD creativity. The relationship between technology traps and new product innovation is indirect and moderated by entrepreneurial orientation and network learning. Entrepreneurial orientation but not network learning is the remedy for highly market-oriented firms to reduce technology traps. The implications, limitations, and future research directions are also discussed. 
This Dissertation Is Dedicated To My Dearest Husband,

Children, And Parents, Who Have Provided Boundless Love, Encouragement And Support In My Life 


\section{ACKNOWLEDGMENTS}

The five-year Ph.D. program at the Kenan-Flagler Business School has been one of the most challenging and rewarding learning experiences in my life. I would not have been able to complete this dissertation and Ph.D. program without the considerable support from a number of faculty, family, colleagues, and friends.

Foremost, I'd like to express my deep appreciation to my committee members. First, I want to thank my advisor Hugh O’Neill, for his unwavering support and unceasing encouragement. During the past years at UNC, Hugh was the primary source of my inspiration and intellectual motivation. Without him, I could not have finished the program or the dissertation. Second, my appreciation goes to Neil Morgan, for his intellectual contribution in shaping me as a growing scholar. In my years at UNC, no progress could move forward without Neil's precise and detailed feedbacks and suggestions. His valuable guidance and feedback substantially improved this research. Third, I have greatly benefited from Bill Perreault's support and guidance. Bill has assisted in keeping me on track in every important step of this Ph.D. program. His long e-mails have taught me many wisdoms about my studies and my career. Fourth, Kwaku Atuahene-Gima is one of the most influential people in my life. I was most fortunate to have him as my advisor for my master's degree. He introduced me to this wonderful academic world. On my way toward earning a Ph.D., he continued to guide me and provide endless support and help. He has pointed out this valuable 
research direction for me, and he used his research grant to help me collect the data for this dissertation research. I wholeheartedly thank Kwaku for having faith in me. Professor Annette Ranft also deserves thanks for her great trust. I am very grateful for having such an exceptional doctoral committee. Without the committee members' contribution of time and expertise, my dissertation would not be in its current shape.

I cannot thank Professor Laura B. Cardinal from Tulane University enough, for her generous time and valuable counsel when it was needed most! She taught me how to stand strong when facing hardship and difficulties. In addition, Professor Bohong Sun from Carnegie Mellon University has been my mentor on both academic and personal issues. Her insightful comments have always encouraged me to pursue excellence in my career. In addition, I am also indebted to Professor Nan Zhou from the City University of Hong Kong for his trust and encouragement. He has provided me valuable data sets and allowed me to work with him on various research projects.

My sincere gratitude and appreciation also go to professors Paul Bloom, Charlotte Mason, Gary Armstrong, C. L. Kendall, William P. Putsis, and Sridhar Balasubramanian, as well as many other faculty members, for their help, suggestions, and concern during different states of my doctoral program.

My colleagues and friends in the doctoral program have been special to me. Tae-Yeol Kim, Scott Turner, Zhike Lei, Wooseong Kang, Sebastian Heese, Min Zhao, Xuanli Xie, Chuanyin Xie, Asda Chintakananda, and Zhonglan Dai, as well as other Ph.D. students, have been witness to the many ups and downs, and we have shared many good and bad times together. Their sharing and friendship have walked me through the challenging years. 
I want to acknowledge the financial support from the Kauffman Foundation for its Dissertation Fellowship $(\$ 15,000)$ and from Pennsylvania State University's Institute for the Study of Business Markets (ISBM) Doctoral Dissertation Award (\$5000). Their support and recognition means a lot for me and my career.

My deep gratitude is also extended to Joanne Scharer, Melanie Sinche, and Timothy Stiles. Their caring, help, and support in several critical periods have made my Ph.D. possible. I would like to thank many other friends for their friendship and support: Lili Lai, Ping Chen, Eric, Fujun Lai, Margaret, Mao, Tony, Professor Liu, Anand, Everett, Monica, Shannan, Ramin, Nicholas, Mike, Mitra, and Mahbobeh.

Finally, my special thanks are extended to my family. My dearest husband, Ardel, has provided endless support and encouragement to me through the doctoral program. He introduced a spiritual world to me. He shared my very struggle and joy on the path to earn a Ph.D. He, more than any other person, has enabled me to recognize my potential. His unselfish love, understanding, and trust have given me tremendous strength and faith to overcome the difficulties. He has often challenged my writing, thinking, and speaking, which urged me to strive for the academic excellence. Without him, the dissertation would not be completed and this degree would not be possible.

I am extremely grateful for my parents' love, encouragement, and support. My parents extended their passion for the high-level education and science to me. My father, a professor in computer science in China, has shared with me many of his experiences and wisdom on both academic and life issues. My mother was the strongest support for my education. They have often given me valuable advice, reminders, and wisdom about life. Their continuous encouragement and emotional support meant a lot to me and motivated me 
to achieve high standards in my academic career. My thanks also go to my sister and brother, for their concern for my well-being. My sister's caring voice on the phone still warms my heart.

Looking back over the last five years at UNC, I realize how many memories I have left here: my joy and my happiness, my tears and sadness, my struggle and my growth. I love beautiful Carolina Blue. I love our championship basketball team. I love our excellent IT help-desk service. I am proud of wearing Carolina Blue. I hope that the Carolina Blue will also be proud of having me as one of their thousands of Ph.D.'s who have contributed to the progress of the scientific world. 


\section{TABLE OF CONTENTS}

Page

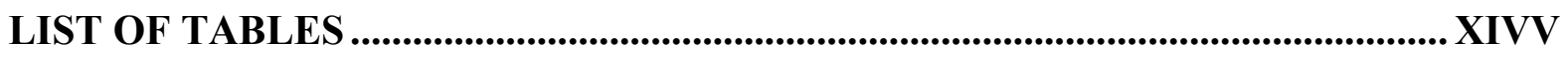

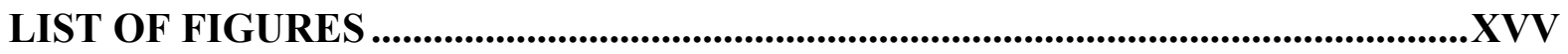

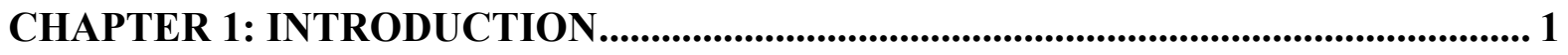

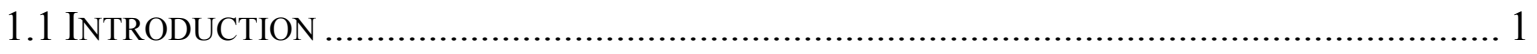

1.2 RESEARCH GAP AND QUESTIONS ...................................................................... 5

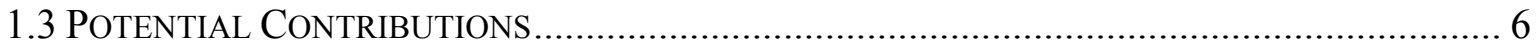

1.4 STUDY OUTLINE .............................................................................................. 7

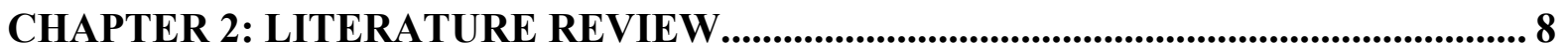

2.1 Literature REVIEW ON NEW Product INNOVATION.............................................. 8

2.1.1 Defining New Product Innovation.............................................................. 9

2.1.2 Radical and Incremental Product Innovation .............................................. 11

2.1.3 Determinants of New Product Success............................................................ 14

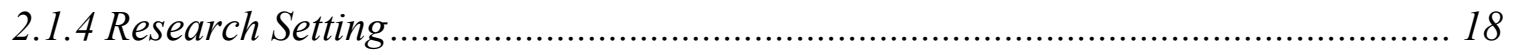

2.2 LITERATURE REVIEW ON MARKET ORIENTATION.............................................. 18 
2.2.1 Definition and Measurement of Market Orientation.............................................. 19

2.2.2 Antecedents and Consequences of Market Orientation ...................................... 24

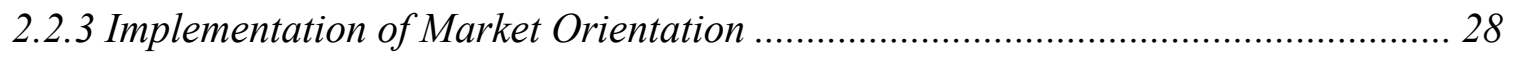

2.2.4 The Relationship Between Market Orientation and New Product Innovation........ 29

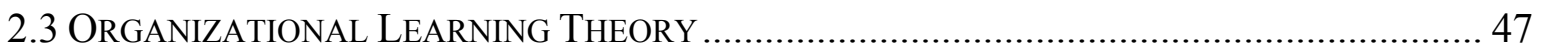

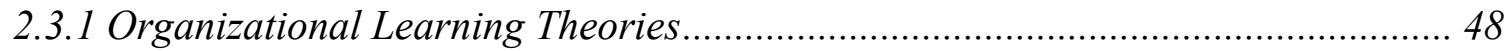

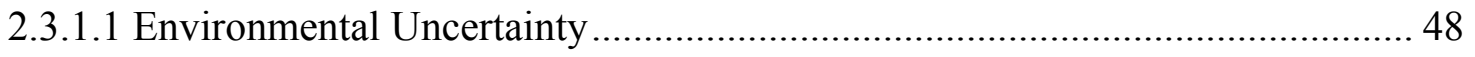

2.3.1.2 Different Perspectives on Organizational Learning ........................................ 50

2.3.1.3 Network Perspective on Organizational Learning .......................................... 57

2.3.2. Applications of Organizational Learning Theories ........................................... 65

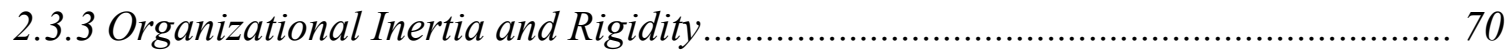

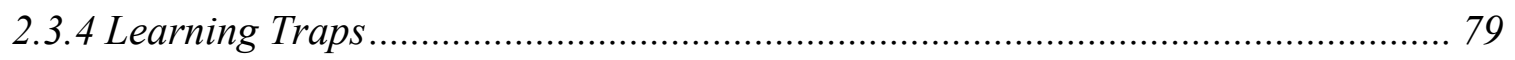

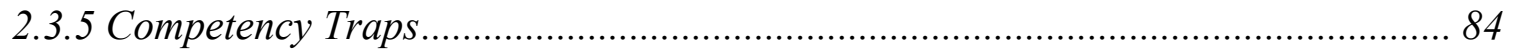

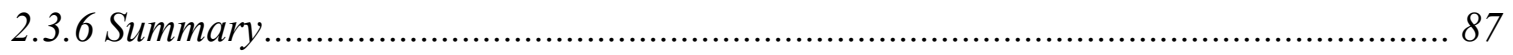

2.4 LITERATURE REVIEW ON ENTREPRENEURIAL ORIENTATION ......................................... 88

2.4.1 Entrepreneurship and Corporate Entrepreneurship.......................................... 88

2.4.2 Definition of Entrepreneurial Orientation ........................................................ 90

2.4.3 Measurement of Entrepreneurial Orientation....................................................... 92

2.4.4 Entrepreneurial Orientation and Performance................................................ 93

CHAPTER 3: THEORETICAL FRAMEWORK AND HYPOHTESES ......................... 96

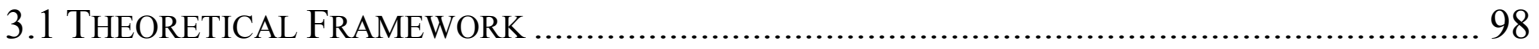

3.1.1 Capability-Rigidity and Institutional Theories ................................................. 98 
3.1.2 Organizational Learning Theory …………………......................................... 99

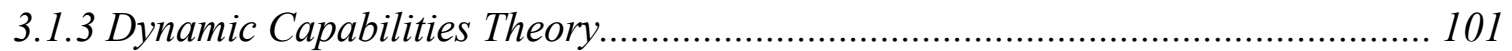

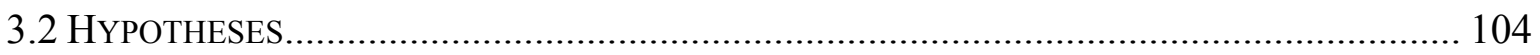

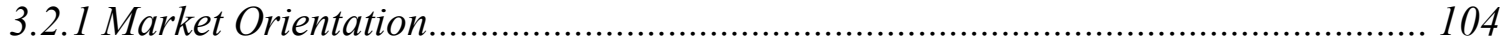

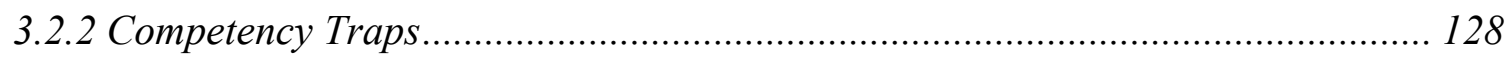

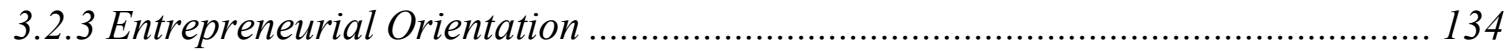

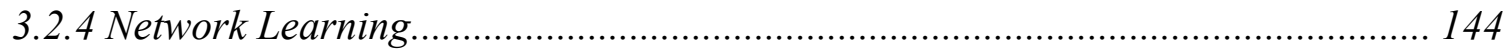

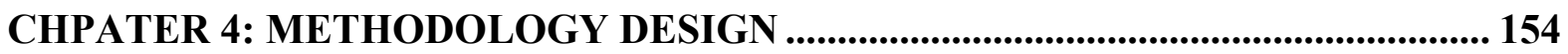

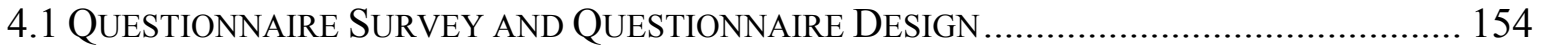

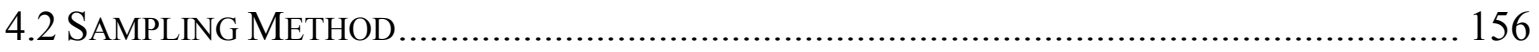

4.2.1 The Cross-Sectional Field Study ……………......................................... 156

4.2.2 Sample Frame and Selection Process …………......................................... 156

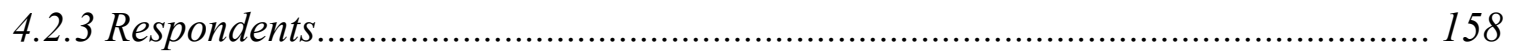

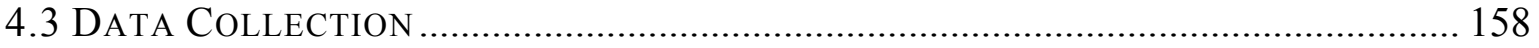

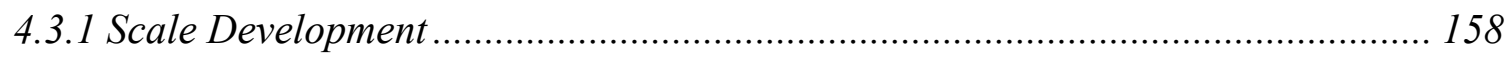

4.3.2 Data-Collection Procedures ......................................................................... 159

4.4 DATA ANALYSIS AND MEASUREMENTS ................................................................... 160

CHAPTER 5: DATA ANALYSES AND DISCUSSION............................................... 171

5.1 CHARACTERISTIC OF THE SAMPLE ………................................................................. 171

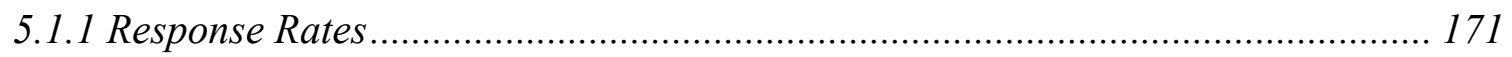

5.1.2 Characteristics of Firms and Respondents ................................................... 172 
5.2 MEASUREMENT DEVELOPMENT.

5.2.1 General Procedure for Measure Development .............................................. 175

5.2.2 Development of Competency Traps: Pretest Study Validation ........................... 178

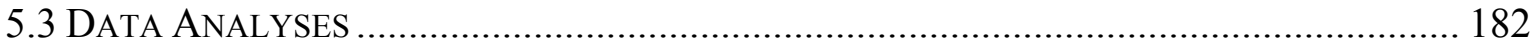

5.3.1 Measurement Models ................................................................................ 182

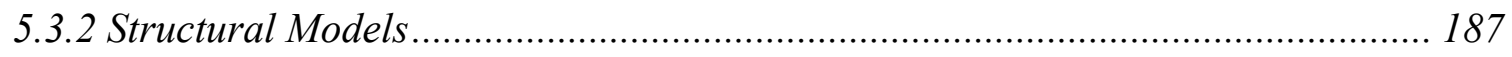

5.3.2.1 Results of Hypotheses Testing: Direct Relationships $\left(\mathrm{H}_{1 \mathrm{a}-\mathrm{c}}-\mathrm{H}_{7 \mathrm{a}-\mathrm{c}}\right) \ldots \ldots \ldots \ldots \ldots . . . . .188$

5.3.2.2 Results of Hypotheses Testing: Moderating Relationships $\left(\mathrm{H}_{8 \mathrm{a}-\mathrm{c}}-\mathrm{H}_{11 \mathrm{a}-\mathrm{c}}\right) \ldots . . .193$

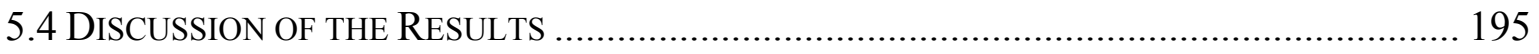

5.4.1 Discussion of Results: Direct Relationships $\left(H_{1 a-c}-H_{7 a-c}\right)$............................. 197

5.4.2 Discussion of Results: Moderating Relationships $\left(H_{8 a-c}-H_{11 a-c}\right) \ldots \ldots \ldots \ldots \ldots \ldots \ldots \ldots . . . . . . . . . . . .200$

CHAPTER 6: IMPLICATIONS, LIMITATIONS, CONCLUSIONS........................... 204

6.1 REVIEW OF THE RESEARCH QUESTIONS IN THE STUDY ......................................... 204

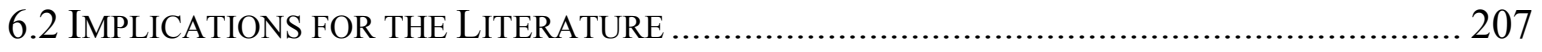

6.3 IMPLICATIONS FOR PRACTITIONERS ................................................................. 209

6.4 LiMITATIONS AND DIRECTIONS FOR FUTURE RESEARCH ...................................... 210

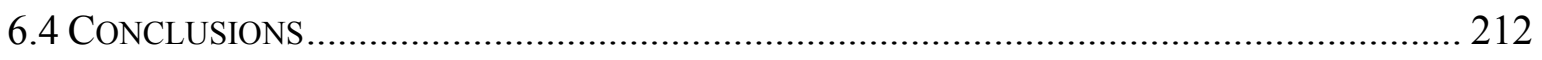

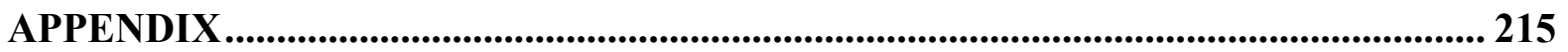

REFERENCES.......................................................................................................... 22 


\section{LIST OF TABLES}

Table

Page

\section{CHAPTER2}

TABle 2. 1 Summary OF EMPIRICAL STUdiES ON THE RELATIONSHIP BETWEEN MO AND

BUSINESS PERFORMANCE 30

TABLE 2. 2 SumMARY OF PREVIOUS Literature ON MO IMPLEMENTATION 37

TABle 2. 3 Summary of EMPIRICAL StUdies On THE RELATIONSHIP BETWEEN MO AND

INNOVATION/NPP 39

\section{CHAPTER 5}

TABLE 5. 1 CHARACTERISTICS OF FIRMS AND RESPONDENTS ........................................... 173

TABLE 5. 2 TyPeS OF BusinesS For PARTICIPATING FIRMS ........................................... 174

TABLE 5. 3 OWNERShIP OF PARTICIPATING FIRMS..................................................... 174

TABLE 5. 4 Summary For MEASUREMENTS Before AND AfTER PreteSt ......................... 176

Table 5. 5 Measure of Competency Traps Before And After Pretest...................... 180

TABle 5. 6 Descriptive Statistics And Correlations of the Study Constructs (A=

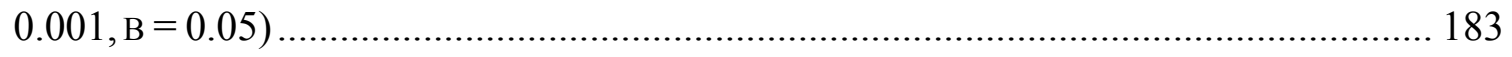

TABle 5. 7 Measurement Models (From 113 Marketing Managers) ......................... 184

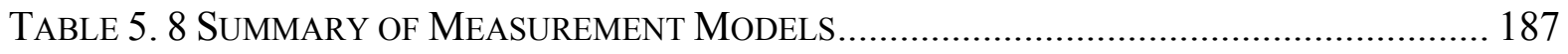

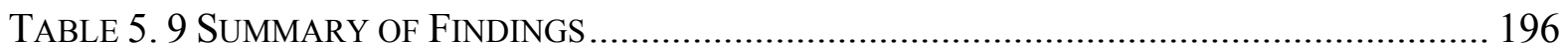




\section{LIST OF FIGURES}

Figure $\quad$ Page

Figure 3.1 ReseARch Model AND Hypotheses ........................................................ 97

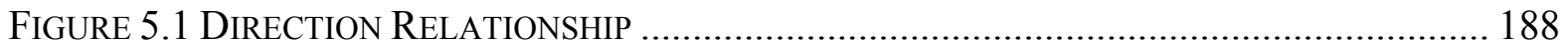

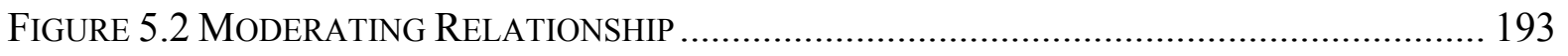

Figure 5.3 Interaction BETWEEN MO AND EO on TECHNOLOGY TRAPS......................... 202

Figure 5.4 INTERACTION BETWEEN MARKET ORIENTATION AND NETWORK LEARNING ON

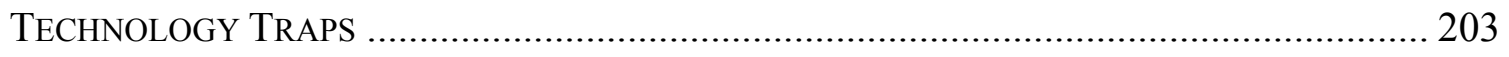




\section{CHAPTER 1: INTRODUCTION}

\subsection{Introduction}

Enhanced understanding of successful new product innovation in business markets is important for both academic research and business practice. However, the management and marketing literatures offer very different viewpoints on this key issue. In the management literature, Christensen and Bower (1996) argue that proximity to customers may harm firms during a period of industry discontinuity, because close customer ties deter product or service innovation. Some scholars argue that customers lack foresight and do not know what they want, with the result that customer orientation encourages product imitation rather than product creativity and conservative product development rather than radical innovation (e.g., Bennett and Cooper 1979, 1981). A focus on current markets can therefore lead to a bias against radical new product innovations and product cannibalization (Chandy and Tellis 1998; Tauber 1974).

These views contradict market orientation (MO) theory in the marketing literature (Slater and Narver 1998). The literature suggests that customer orientation, competitor orientation, and interfunctional coordination are components of MO (Narver and Slater 1990). Market-oriented firms are viewed as being concerned with both express and latent customer needs and not simply as being customer led (Slater and Narver 1999). Slater and Narver $(1995,1998)$ argue that MO can lead to generative as well as adaptive learning in 
firms' new product development (NPD) efforts. The marketing literature therefore indicates that as a component of $\mathrm{MO}$, customer orientation provides valuable insights to the NPD process. Learning from lead users or customers is considered a valuable source of novel product concepts (von Hippel 1989). Indeed, according to von Hippel (1989), users developed 77 percent of innovations in scientific instruments and 67 percent of those in semiconductors. In support of this viewpoint, a number of empirical studies have shown a positive relationship between MO and new product success (Agarwal, Erramilli, and Dev 2003; Atuahene-Gima 1995; Baker and Sinkula 1999a, b; Han, Kim, and Srivastava 1998; Matear et al. 2002; Pelham and Wilson 1996; Slater and Narver 1994). However, a number of studies show no direct impact of MO on new product success (Appiah-Adu and Ranchhod 1998; Atuahene-Gima 1996; Greenley 1995; Im and Workman 2004; Langerak, Hultink, and Robben 2004).

This dissertation seeks to resolve the controversies in this debate. From the management side, the work of Christensen and Bower (1996) adopts a specific focus on discontinuous innovation. From the marketing side, most studies do not explicitly specify whether the focus on new product improvement is based on incremental or radical innovation. Furthermore, the mixed empirical results concerning the relationship between $\mathrm{MO}$ and new product performance suggest that $\mathrm{MO}$, by itself, does not explain variance in new product success. Research is clearly needed to identify the key variables that moderate or mediate the relationship between $\mathrm{MO}$ and successful new product innovation, and thus explain the conflicting findings and arguments about the benefits and limitations of $\mathrm{MO}$ as it pertains to successful new product innovation in business markets. 
From an organizational learning perspective, MO may be considered a market learning capability, which has a positive effect on NPD. However, the literature shows that organizational learning is not always beneficial for firms. Organizational learning sometimes leads to dysfunctional behavior and can create negative effects (Crossan, Lane, and White 1999; Foil and Lyles 1985). Leonard-Barton (1992) argues that organizational capabilities have a downside that inhibits innovation: when capabilities become rigidities. Organizations have to struggle with whether to maintain, renew, or replace organizational capabilities, because such capabilities simultaneously enhance and inhibit development.

This struggle is described as a balance between exploration and exploitation in the organizational learning process (March 1991). Exploration learning focuses on experimentation with new alternatives. Exploitation learning emphasizes the refinement and extension of existing competences, technologies, and paradigms (March 1991). As a result of "learning myopia," organizations are more likely to engage in exploitation activities rather than exploration activities, because returns from exploitation are systematically more certain and less remote in time than are returns from exploration. In such adaptive learning processes, the advantages of exploitation cumulate more rapidly than those of exploration. These tendencies to increase exploitation and to reduce exploration make the learning process potentially self-destructive are called learning traps (March 1991). Learning traps can make firms so blind that not only can they not see the importance of a new routine or new technology, but they also try to ignore other potential possibilities (King and West 2002).

The literature indicates that among various types of learning traps, competency traps may be the most common and also potentially the most dangerous. Levitt and March (1988) 
and Levinthal and March (1993) define competency traps as the persistence of inferior procedures. With a history of favorable performance, an organization tends to accumulate experience with a legacy procedure and avoids experience with a newly emerging procedures (Levinthal and March 1993; Levitt and March 1988). This inertia or rigidity in organizational learning keeps firms from identifying the need for and from developing adequate experience with a superior procedure. A competency trap is the likeliest explanation for the failure of market leaders (King and West 2002). Market-oriented firms are confident in their existing technology and established processes because they provide favorable outcomes, which leads to blindness to new concepts, new approaches, and the potential for radical innovation.

Therefore, this dissertation argues that competency traps are an important mediator of the link between $\mathrm{MO}$ and new product innovation. Market orientation as a capability may improve new product efficiency and incremental innovation. However, MO may also constrain innovative NPD to become a rigidity, manifest in the form of competency traps that inhibit new product creativity and radical innovation. Because of a lack of mature measurements for radical innovation and incremental innovation, this study examines innovation by focusing only on new product creativity and NPD efficiency. In order to reduce competency traps and enhance a firm's ability to develop innovative new products, the literature suggests that market-oriented organizations must conduct double-loop or generative learning by developing and leveraging both complementary assets, such as entrepreneurship, and appropriate organizational structures and processes (Slater and Narver 1995). This dissertation proposes that entrepreneurial orientation and network learning may help reduce the tendency of MO to create competency traps by enhancing a firm's ability to recognize new opportunities and create novel perspectives. 


\subsection{Research Gap and Questions}

This study seeks to enhance understanding of successful new product innovation by developing and testing a new theory framework for explaining the MO-product innovation relationship in the context of firms' NPD processes. Drawing on and adapting key concepts from organizational learning theory, particularly in the area of capability-rigidity theory, this dissertation posits that the key construct of competency traps mediate the relationship between MO and new product innovation. Competency traps concern the propensity of a firm to continue relying on processes that have been successful in the past even though they are no longer optimal. Although the concept of competency traps was introduced in management literature more than a decade ago, it has been the focus of little conceptual development and no empirical research. Given the potential adverse consequences of competency traps in NPD, it is important that we understand the sources and impact of competency traps. An integrated conceptual framework is needed to help researchers and managers identify and reduce the effect of competency traps on NPD. Furthermore, the development of a valid measure of competency traps should enable researchers and managers to better diagnose competency traps and remedy their possible adverse effects. This study develops an integrated model to bridge the marketing and management literatures with data from the business-to-business arena.

Specifically, this dissertation seeks answers to the following questions:

1. What are competency traps? How can we define and measure them?

2. What kind of relationship exists among MO, competency traps, and new product innovation? Why and how does a firm competence such as MO lead to competency traps? What are the consequences of competency traps for new product innovation? 
3. How can firms reduce the occurrence and negative consequences of competency traps? Why and how does this work?

\subsection{Potential Contributions}

Competency traps can lead firms into a vicious cycle of adherence to inferior routines and denial of the need for change (Fiol and Lyles 1985; King and West 2002; Levinthal and March 1993; Levitt and March 1988). Both academic research and practice in business markets can greatly benefit from this dissertation by understanding how firms can identify and reduce the level and negative consequences of competency traps in their NPD efforts. This dissertation will contribute to the literature and management practice in three ways. First, this study will clarify and specify the domain of competency traps and develop new measures to help firms diagnose the existence and level of competency traps. Second, this dissertation will provide empirical evidence concerning capability-rigidity theory. To date, the upsides of an MO as an organizational capability have been the sole focus of attention in the literature to date. This dissertation will assist managers in recognizing that the potential downsides of MO may cause rigidity in a firm's competency traps, which may reduce new product creativity and inhibit radical innovation in NPD. Third, by identifying important antecedents of competency traps and factors that affect their relationships with NPD performance, this dissertation will help managers manage the level and negative impact of such competency traps. This dissertation suggests entrepreneurial orientation and network learning as potentially important complementary assets to $\mathrm{MO}$ that can be used to remedy competency traps in the NPD process.

In general, I expect that my findings will be applicable to many firms. If the framework is supported, the findings of this dissertation should provide an answer to the 
debate about whether customer power has adverse effects on innovation. Consistent with Christensen and Bower (1996), I argue that customer orientation alone is insufficient as a precursor of radical innovation in NPD. In extending the work of Slater and Narver (1998, 1999), this dissertation will show how complements to MO may minimize competency traps and encourage new product innovation. The creation of double-loop learning opportunities by means of the fostering of entrepreneurial orientation and network learning helps firms reduce competency traps and thereby increase innovation and creativity.

\subsection{Study Outline}

This dissertation is organized into six chapters as follows:

Chapter 1, the current chapter, provides a general overview of the study, including the research background, research questions, and potential contribution;

Chapter 2 presents a review of the empirical and theoretical literature;

Chapter 3 addresses the theoretical framework and hypotheses;

Chapter 4 describes the research design and methodology, including the sample, datacollection procedure, measurement, and data-analysis methods;

Chapter 5 analyzes and discusses the findings of the study; and Chapter 6 discusses the implications, limitations, and directions for future research.

This chapter is the introductory chapter. Relevant research background was examined in order to isolate the main research issue. A debate about the relationship between market orientation and innovation was introduced first. After that, the research questions were described. Then, research gaps and potential contributions were identified. At the end, the outline of this study was addressed. In the next chapter, a detailed literature review will be presented. 


\section{CHAPTER 2: LITERATURE REVIEW}

This chapter examines the relevant literature on NPD, market orientation, organizational learning (including competency traps and network learning), and entrepreneurial orientation. The development of this chapter is therefore geared to present and discuss the most relevant literature to the research questions under examination and to build a theoretical rationale for the selection of the dependent and independent variables applied in this dissertation.

\subsection{Literature Review on New Product Innovation}

The Marketing Science Institute (2002-2004) has named new product development (NPD) and innovation a top-tier priority topic. New product development is the most common form of innovation (Hlavacek and Thompson 1973) and is not only risky but also costly. More than 50 percent of new products fail in the marketplace (Christensen and Raynor 2003a, b; Golder and Tellis 1993). The term innovation has a broad meaning in the literature and has been used to cover numerous concepts and variables, including new idea, new concepts, new invention, new technology, new program, new products, and so on. For the purposes of this dissertation, however, I consider innovation and new products interchangeable and combine them in the term new product innovation. When Wind and Mahajan (1997) discuss the research issues and opportunities in NPD, how to help management improve the probability 
of successful NPD is revealed as one of the most important questions for both researchers and practitioners.

\subsubsection{Defining New Product Innovation}

Academic researchers and practitioners have been interested in understanding the meaning and manifestations of innovation for many decades. An examination of the literature on innovation shows that scholars have classified innovations on the basis of the specific context of the research setting, such as product, technology, and organizational innovation. In this section, I first review the different definitions of innovation.

Van de Ven (1986) defines innovation as "the development and implementation of new ideas by people who engage in transactions with others within an institutional order (p590)". This definition focuses on four basic factors: new ideas, people, transactions, and institutional context.

Roberts (1988) considers innovation as having two parts: (1) the generation of an idea or invention and (2) the conversion of that invention into a business or other useful application. Therefore, innovation includes all stages from the actual invention to the final commercialization, or innovation equals the sum of invention and exploitation. The overall management of technological innovation therefore includes the organization and direction of human and capital resources toward effectively (1) creating new knowledge; (2) generating technical ideas aimed at new and enhanced products, manufacturing processes, and services; (3) developing those ideas into working prototypes; and (4) translating them into manufacturing, distribution, and use. Technological innovation outcomes may come in many forms, incremental or radical in degree. Whereas invention is marked by discovery or a state 
of new existence, usually at the lab or the bench, innovation is marked by first use in manufacturing or in a market (Roberts 1988).

Ettlie, Bridges, and O'Keefe (1984) suggest that radical innovation and incremental innovation differ in whether the technology of the innovation is a clear, risky departure from existing practice. If the innovation requires both throughput (process) as well as output (production or service) change, perhaps the magnitude or cost required of the organization is sufficient to warrant the designation of rare and radical, rather than incremental, innovation. Radical and incremental describe different types of technological process innovations (Dewar and Dutton 1986). Radical innovations are fundamental changes that represent revolutionary change in technology. They represent significant departures from existing practice. Radical innovations create a dramatic change in products, processes, or services such that they transform existing markets or industries, or create new ones. Incremental innovations are minor improvements or simple adjustments in current technology. Examples of radical innovation include computerized tomography, magnetic resonance imaging (MRI) in the field of diagnostic imaging, personal computers in computing, and pagers and cellular telephones in mobile communications (Leifer, McDermott, O’Connor, Peters, Rice, and Veryzer 2000). Cardinal (2001) defines radical innovation and incremental innovation from a knowledge perspective. Radical innovations are major changes in technology that involve the discovery of new knowledge, substantial technical risk, time, and cost. Incremental innovations are minor changes to existing technology that involve small advances based on an established foundation of knowledge.

Henderson and Clark (1990) use the traditional definition of innovation. They view the product as a system and as a set of components. Innovation is classified along two 
dimensions: (1) horizontal (components) and (2) vertical (linkage among components). Radical innovation establishes a new dominant design and a new set of design concepts embodied in components that are linked together in a new architecture. Incremental innovation refines and extends an established design. Improvement occurs in individual components, but the underlying core design concepts and the links between them remain the same. A modular innovation changes a core design concept without changing the product's architecture. Architectural innovation is the reconfiguration of an established system to link together existing components in a new way.

In this dissertation, I view innovation from the new product management perspective. According to Crawford and Di Benedetto (2000), innovation is (1) the act of creating a new product or process, including invention as well as the work required to bring an idea or concept into final form, and (2) a particular new product or process outcome. An innovation may have various degrees of newness, from very little to highly discontinuous, but the innovation must include at least some degree of newness to the market and not just to the firm (Crawford and Di Benedetto 2000).

\subsubsection{Radical and Incremental Product Innovation}

According to Leifer and colleagues (2000), it is very important to understand radical innovation because it transforms the relationship between customers and suppliers, restructures marketplace economics, displaces current products, and often creates entirely new product categories. It may provide a platform for the long-term growth that corporate leaders desperately seek. Radical innovation concerns the development of new business or product lines that are based on new ideas, technologies, or substantial cost reductions. Therefore, it 
requires exploration competencies (Leifer et al. 2000). Incremental innovation usually emphasizes cost or feature improvements in existing products or services, and it requires competencies in the exploitation of existing knowledge.

Gersick (1991) applies the concept of punctuated equilibrium to explain the balancing process of radical and incremental innovation. Punctuated equilibrium is an alternation between long periods in which stable infrastructures permit only incremental adaptations and brief periods of revolutionary upheaval. In Gersick's study, most organizational transformations were accomplished by means of rapid and discontinuous change over most or all domains of organizational activity. Small changes in strategies, structures, and power distributions did not accumulate to produce fundamental transformations. Therefore, it appears that firms evolve through relatively long periods of stability or equilibrium in their basic patterns of activity but relatively short periods of fundamental or revolutionary change punctuate this activity (Romanelli and Tushman 1994).

Scholars generally consider radical innovations engines of economic growth (Sorescu, Chandy, and Prabhu 2003). Many researchers and practitioners are interested in why some firms are more successful at introducing radical product innovations than others. Chandy and Tellis (1998) identify a firm's willingness to cannibalize as the key variable for differentiating firms with and without strong radical products. Sorescu, Chandy, and Prabhu (2003) collect information from the pharmaceutical industry to study the sources and consequences of radical innovation. Their results indicate that most radical innovations come from a minority of firms. Firms with higher per-product levels of marketing and technology support obtain much greater financial rewards from their radical innovations than do other firms. Firms with 
greater depth and breadth in their product portfolio also gain more from their radical innovations.

Song and Montoya-Weiss (1998) examine whether the development of really new products requires a different approach from that of the development of incremental new products. Their empirical study suggests that strategic planning, market analysis, technical development, and product commercialization are key determinants of new product success for both really new products and incremental products. However, strategic planning and businessand market-opportunity analysis activities play contrasting roles for the two types of products. Proficiency in business and market opportunities analysis may be negatively related for really new products, but it can increase the profitability of incremental products. Conversely, improving the proficiency of strategic planning activities is positively related to the profitability of really new products but negatively related to that of incremental products. Overall, in this study, really new products surpass incremental products in meeting profit objectives.

O'Connor (1998) examines whether customer input plays the same key role in every successful NPD project. Breakthrough new products require firms to visualize the market and build and create demand for the product, whereas incremental new products require firms to listen to the market and effectively and efficiently address existing demand. Since a radical innovation creates a line of business that is new not only for the firm but also for the marketplace, customers are highly likely to be unable to describe their requirements for a product that opens up entirely new markets and applications. O'Connor (1998) therefore suggests that internal data and informal networks of people throughout relevant business units provide the means for learning about the hurdles that the innovation faces and the markets that 
are unfamiliar to the development group. Offering the product to the most familiar market and using a strategic ally who is familiar with the market as an intermediary between the project team and the marketplace can reduce market uncertainty.

Booz Allen Hamilton (1982) examines new product introductions to find that only a small percentage of all new products are "new-to-to-the-world products." To keep the balance between incremental and breakthrough innovation, as well as between short- and long-term innovation, Booz Allen Hamilton argues that organizations should include breakthrough innovation as one of the objectives of NPD. They also should ensure that the organizational architecture - which includes the process, culture, structure, people, resources, technology, and incentives for NPD - is capable of developing breakthrough innovations. In order to understand the determinants of radical innovation, I review knowledge about the determinants of general new product success in the following section.

To summarize the literature, in this dissertation, I consider that radical new products are much more creative than incremental new products. But incremental NPD is much more efficient than radical NPD because it takes less time, fewer resources, and less risk to develop them.

\subsubsection{Determinants of New Product Success}

Because of the importance of new product innovation to firm performance, there have been many studies that focus on the determinants of new product performance (NPP). Montoya-Weiss and Calantone (1994) and Henard and Szymanski (2001) conducted two important meta-analyses that synthesize the results of the numerous empirical studies of the determinants of NPP. 
Montoya-Weiss and Calantone (1994) review 47 new product studies and developed quantitative comparisons of their results. They suggest 18 factors that capture the essence of research on the determinants of NPP in four major categories: (1) new product strategy, (2) market environment, (3) product-development process execution, and (4) the organization. New product strategic factors include product advantage, market synergy, strategy, and company resources, where product advantage is the product's superiority with respect to quality, cost-benefit ratio, or function over competitors' products. Technological synergy occurs when engineering resources required by new product projects are available in the firm. Market synergy refers to the marketing skills and resources required by the new product compared with the firm's existing skills and resources in sales, customer service, marketing research, and advertising and promotions. Strategy refers to the strategic motivation for the project development, such as defensive, reactive, proactive, or imitative. Company resources indicate compatibility of the firm's resource base with the project requirements, such as capital, manufacturing, and workforce requirements.

Market environment factors include market potential, market competitiveness, and environment, where market potential is the size and growth of the market, market competitiveness is the intensity of competition in the marketplace, and environment is risk or uncertainty and the regulatory environment.

Product-development process factors include the following eight new product process activities: (1) protocol; (2) proficiency of predevelopment, market-related, and technological activities; (3) top management support; (4) control and skills; (5) speed to market; (6) cost; and (7) financial analysis. Proficiency of technical activities is the proficiency of product development, in-house testing of the product or prototype, production start-up, and the 
obtaining of necessary technology. Proficiency of marketing activities is the proficiency of marketing research, customer tests of prototypes and samples, test markets, service, advertising, distribution, and market launch. Proficiency of predevelopment activities is the efficiency with which the firm performs preliminary market and technical assessment, market study, market research, initial screening, and preliminary business analysis.

Organizational factors include internal and external communication and other organizational structure factors. Internal and external communication is the coordination and cooperation within the firm and between firms. Organizational structure factors include measures of organizational climate, size, centralization, reward structure, and job design.

In summary, Montoya-Weiss and Calantone's (1994) meta-analysis suggests that new product strategy, market environment, product-development process execution, and organizational factors are significant for new product success.

Seven years later, Henard and Szymanski (2001) conducted another meta-analysis of new product management. They identify 24 variables in four different categories: (1) product, (2) strategy, (3) process, and (4) marketplace. Product characteristics are the elements pertaining to the products and services, including product advantage (i.e., the superiority and/or differentiation of the product over competitive offerings), whether the product meets customer needs (i.e., extent to which the product satisfies customers' desires or needs), product price (i.e., perceived performance congruency), product technological sophistication (i.e., high-tech or low-tech), and product innovativeness (i.e., perceived newness, originality, uniqueness, or radicalness of the product).

Firm strategy characteristics are a firm's planned actions that can potentially provide competitive advantage in the marketplace separate from any factors associated with the NPD 
process. These characteristics include marketing synergy (congruency between the existing marketing skills of the firm and the marketing skills needed to execute a new product initiative successfully), technological synergy (congruency between the existing technological skills of the firm and the technological skills needed to execute a new product initiative successfully), order of entry (timing of marketplace entry for a product or service), dedicated human resources (focused commitment of personnel resources to a new product initiative), and dedicated research and development $(R \& D)$ resources (focused commitment of R\&D resources to a new product initiative)

Firm process characteristics refer to the elements associated with the NPD process and its execution in a new product initiative. They include structured approach (employment of formalized product-development procedures), predevelopment task proficiency (execution of prelaunch activities, e.g., idea generation and screening, market research, and financial analyses), marketing task proficiency (conduct in marketing activities), technological proficiency (use of technology), launch proficiency (launch of product or service), reduced cycle time (i.e., in concept-to-introduction time line), market orientation (degree of orientation to internal, competitor, and customer environments), customer input (incorporation of customer specifications), cross-functional integration (degree of multiple-department participation), cross-functional communication (level of communication among departments), senior management support (degree of senior management support).

Marketplace characteristics pertain to target-market elements in a new product introduction, including likelihood of competitive response, competitive response intensity and turbulence, and market potential (i.e., anticipated growth in customers and/or customer demand). 
In summary, Henard and Szymanski's (2001) meta-analysis suggests that product, strategy, process, and marketplace are the significant factors that impact NPP.

Although these two meta-analyses provide good pictures of the determinants of new product success, they do not differentiate radical new product success from incremental new product success. Most of the determinants are suitable for incremental new product success and emphasize the efficiency aspect of NPP rather than the effectiveness or creativeness aspect, which is important for radical new product success.

\subsubsection{Research Setting}

In this dissertation, I argue that some firms' process characteristics, such as $\mathrm{MO}$, may lead to rigidity or inertia. This rigidity or inertia may enhance incremental NPD and NPD efficiency, but it may block radical NPD and decrease new product creativity. For this study, I have selected the impact of market orientation (MO) on new product innovation. In addition, I will suggest two important variables in firm characteristics that work against rigidity or inertia: (1) entrepreneurial orientation and (2) network learning.

In the following section, I review the literature on $\mathrm{MO}$ and illustrate in detail the relationship between $\mathrm{MO}$ and new product innovation.

\subsection{Literature Review on Market Orientation}

Market orientation has been an important Marketing Science Institute research area for more than ten years (Noble, Sinha, and Kumar 2002). It is one of the most important topics for research focusing on organizational-level phenomena that affect marketing strategy and 
management (Varadarajan and Jayachandran 1999). Academicians and practitioners consider MO the very heart of modern marketing management and strategy (Narver and Slater 1990).

Previous researchers have studied market orientation from many different perspectives (Deshpandé and Farley 1999) and in three distinct research streams. The first stream focuses on definitions of the MO construct and its measurement (Bigne, Kuster, and Toran 2003;

Deshpandé, Farley, and Webster 1993; Harris 2002). The second research stream investigates the relationship between MO and business performance (Grewal, Comer, and Mehta 2001; Noble, Sinha, and Kumar 2002) Although some researchers have demonstrated that MO significantly affects new product success and firm performance (Atuahene-Gima 1995; Cooper 1994; Pelham and Wilson 1996; Slater and Narver 1994), other studies do not support this relationship (Appiah-Adu and Ranchhod 1998; Greenley 1995). The third research stream pertains to the implementation or configuration of $\mathrm{MO}$ in complex management practices (Jaworski and Kohli 1993). In the following sections, I review the literature from each stream.

\subsubsection{Definition and Measurement of Market Orientation}

In this section, I review the first research stream, which defines and measures MO. Studies that define MO include those of Day $(1990,1994)$; Deshpandé, Farley, and Webster (1993); Kohli and Jaworski (1990); Narver and Slater (1990); Siguaw, Brown, and Widing (1994); and Wrenn (1997). Studies concerning MO measurement include those of Bigne, Kuster, and Toran (2003); Deng and Dart (1994); Deshpandé, Farley, and Webster (1993); Deshpandé and Farley (1998); Gray, Matear, Boshoff, and Matheson (1998); Harris (2002); Kohli, Jaworski, and Kumar (1993); Narver and Slater (1990); Siguaw and Diamantopoulos (1995); and Wrenn (1997). 
In the literature, MO has been defined from three perspectives: (1) organizational culture (Deshpandé, Farley, and Webster 1993; Homburg and Pflesser 2000; Narver and Slater 1990), (2) organizational behavior (Kohli and Jaworski 1990), and (3) system based. After several years of debate on MO, only two perspectives are widely adopted in the market strategy literature.

The first is Narver and Slater's (1990) cultural perspective. They define MO as "the organization culture that most effectively and efficiently creates the necessary behaviors for the creation of superior value for buyers and, thus, continuous superior performance for the business" (p. 21). They conceptualize MO in terms of three dimensions: (1) customer orientation, (2) competitor orientation, and (3) interfunctional coordination. Customer orientation means that the firms understand their buyers in order to create superior value for them continuously. Competitor orientation is firms' understanding of the short-term strengths and weaknesses and long-term capabilities and strategies of both the key current and the key potential competitors. Interfunctional coordination is the coordinated use of company resources to create superior value for target customers. Long-term focus is related to profits and implementation of each of three behavioral components from a long-term perspective in order to achieve long-term survival. Profitability is the overriding objective of MO.

The second is Kohli and Jaworski's (1990) behavioral perspective. They define MO as "the organization-wide generation of market intelligence pertaining to current and future customer needs, dissemination of the intelligence across departments, and organization-wide responsiveness to it” (p. 6). This definition reflects three components of marketing information processing: (1) marketing intelligence generation, (2) dissemination, and (3) responsiveness in a learning organization. Intelligence generation includes an analysis of exogenous factors that 
influence those needs and preferences and the changing needs of customers throughout the whole organization. Intelligence dissemination is the communication or dissemination of market information to relevant departments and individuals in the organization.

Responsiveness is the action taken in response to market intelligence that is generated and disseminated.

Kohli and Jaworski's (1990) definition is related to that of Narver and Slater (1990). An organization with customer orientation and competitor orientation is involved in all of the activities of acquiring information about buyers and competitors in the target market and disseminating it throughout the business (Narver and Slater 1990). Moreover, the organization must involve the business's coordinated efforts beyond the marketing department in order to create superior value for buyers (Narver and Slater 1990). Market orientation is a system of processing marketing information that pertains to customers and competitors through coordinated efforts across different functional departments in the firm (Jaworski and Kohli 1993; Kohli and Jaworski 1990; Sinkula 1994). Therefore, Narver and Slater’s (1990) behavioral conceptualization is consistent with the propositions of Kohli and Jaworski (1990).

We should distinguish MO from other similar concepts, such as customer orientation - or the set of beliefs that, in order to develop a long-term profitable enterprise, the customer's interest comes first, without excluding those of all other stakeholders, such as owners, managers, and employees (Deshpandé, Farley, and Webster 1993); marketing orientation, or the implementation of the marketing concept (McCarthy and Perreault 1990); and the marketing concept, or customer philosophy, goal attainment, and integration of effort (Houston 1986). 
In summary, there are two definitions that introduce the concept of MO from different perspectives. Kohli and Jaworski (1990) emphasize the process of implementing the concept, and Narver and Slater (1990) focus on behavior. Both definitions are very useful in studying MO from different angles. In this dissertation, I adopt the definition of Narver and Slater (1990) to study MO because most extant empirical studies of MO and innovation (Han, Kim, and Srivastava 1998; Im and Workman 2004; Lukas and Ferrell 2000) have used this conceptualization and its associated operationalization. Therefore, to be able to compare and contrast my results with previous findings, I also have decided to use Narver and Slater's (1990) definition.

After the debate concerning the definition of $\mathrm{MO}$, marketing researchers devoted considerable attention to the development of a valid and reliable measurement scale for MO. Examples of scales that measure MO include those of Narver and Slater (1990); Kohli, Jaworski, and Kumar (1993); Wrenn (1997); and Deshpandé and Farley (1998). Narver and Slater (1990) and Kohli, Jaworski, and Kumar (1993) initiated the research effort in this research stream.

Narver and Slater (1990) surveyed 140 strategic business units (SBUs) across commodity businesses, noncommodity businesses, and businesses within a single corporation. According to their analysis of MO, three behavioral components (customer orientation, competitor orientation, and interfunctional coordination) and two decision criteria (long-term focus and profitability) form a one-dimensional construct. They examined face validity, reliability analysis, and construct validity (including convergent validity, discriminant validity, and concurrent validity) to find results that indicate support for the construct reliability and validity of the three components, but they did not find support for the construct 
reliability of long-term orientation and profit objective. Using nonlinear factor analysis of matched samples of senior marketing and nonmarketing executives from 222 SBUs, Kohli, Jaworski, and Kumar (1993) developed a freestanding 20-item scale.

More empirical efforts have emerged in the literature in order to test the relationship between the scales of Kohli and Jaworski (1990) and Narver and Slater (1990). Deshpandé, Farley, and Webster's (1993) study of 138 Japanese executives developed a customer orientation scale based on extensive qualitative personal interviewing; a detailed survey of available literature, including the work of Kohli and Jaworski (1990) and Narver and Slater (1990); and pretesting in a small sample of firms. The reliability coefficients was greater than .65 .

In order to assess the robustness and generalizability of the existing work on MO, Deshpandé and Farley (1998) used a sample of 82 managers in 27 European and U.S. companies in their integrative, cross-national study, in which they synthesized and retested measurements of Narver and Slater (1990), Kohli, Jaworski, and Kumar (1993), and Deshpandé, Farley, and Webster. (1993). The results of reliability, independent validity check, predictive validity, and discriminant validity tests indicated that all three scales are reliable and valid. In addition, the scales generalize well internationally in terms of reliability and prediction of performance. Furthermore, they tested the interrelationship of all three scales using correlation of the scales and within-firm interrater scale reliabilities. The results showed great confidence in the correlations from multiple respondents in various companies, and the three scales are interchangeable in practice.

In summary, Narver and Slater (1990) and Kohli, Jaworski, and Kumar (1993) have provided valid measures for MO. The reliable and valid $\mathrm{MO}$ measurements from their studies 
led to the second research stream and provided the solid foundation for many further issues. In the following section, I review literature relating to assessment of both the antecedents and the consequences of MO.

\subsubsection{Antecedents and Consequences of Market Orientation}

The second research stream in $\mathrm{MO}$ is the debate about the relationship between $\mathrm{MO}$ and business performance.

Following the development of comprehensive definitions and valid and reliable operationalizations of $\mathrm{MO}$, much research attention has focused on examining the antecedents and consequences of MO (for a review of MO research, see Jaworski and Kohli 1996). Theoretical and empirical studies in the United States include those of Day and Wensley (1988); Kohli and Jaworski (1990); Narver and Slater (1990); Ruekert (1992); Deshpandé, Farley, and Webster (1993); Jaworski and Kohli (1993); Slater and Narver (1994); Pelham and Wilson (1996); and Pelham (1997a, b); Siguaw, Simpson, and Baker (1998); Baker and Sinkula (1999a); Steinman, Deshpandé, and Farley (2000); and Noble, Sinha, and Kumar (2002).

International MO studies include those from continental Europe (Hooley et al. 2003; Pitt, Caruana, and Berthon 1996), the United Kingdom (Appiah-Adu 1997; Appiah-Adu and Ranchhod 1998; Greenley 1995), Australia (Atuahene-Gima 1995, 1996; Farrelly and Pascale 2003; Pulendran, Speed, and Widing 2003), New Zealand (Gray et al. 1998; Matear et al. 2002), the Netherlands (Langerak 2001), Taiwan (Chang and Chen 1998; Horng and Chen 1998), Thailand (Grewal and Tansuhaj 2001), China and Hong Kong (Sin et al. 2003, 2005; Wei and Morgan 2004), and Saudi Arabia (Bhuian 1997). 
More recently, nonprofit organizations (Gainer and Padanyi 2002; Siu and Wilson 1998; Vazquez, Alvarez, and Santos 2002), public organizations (Cervera, Molla, and Sanchez 2001), and political parties (Lees-Marshment 2001; O’Cass 2001a, b) have also been a focus of MO research.

The existing empirical evidence regarding the effects of MO on performance is mixed (see table 2.1). Some studies have linked MO to favorable performance (e.g., Appiah-Adu 1997; Atuahene-Gima 1995, 1996; Egeren and O’Conner 1998; Homburg and Pflesser 2000; Jaworski and Kohli 1993; Narver and Slater 1990; Pitt, Caruana, and Berthon 1996; Slater and Narver 1994). Some studies have linked MO to unfavorable performance (e.g., Bhuian 1997; Gray et al. 1998; Grewal and Tansuhaj 2001). Still others have found that MO has no effect on firm performance (e.g., Greenley 1995; Han, Kim, and Sirvastava 1998; Langerak, Hultink, and Robben 2004; Perry and Shao 2002; Siguaw, Simpson, and Baker 1998). The relationship between $\mathrm{MO}$ and performance is surprisingly more complex than has been previously thought. In the following section, I briefly review the most influential studies about the relationship between MO and firm performance from Journal of Marketing and Journal of Marketing Research.

Narver and Slater (1990) use a sample of 140 business units (both commodity and noncommodity) to study the MO-firm performance relationship. They use subjective return on assets (ROA) to measure firm performance, and the results show a substantial positive effect of MO on the profitability of both types of business.

Kohli and Jaworski (1993) use two national samples to study the antecedents and consequences. Their findings suggest that MO is related to top management's emphasis on the orientation, risk aversion of top managers, interdepartmental conflict and connectedness, 
centralization, and reward system orientation. It is also positively related to organizational commitment, esprit de corps, and overall business subjective performance, but it is not positively related to objective market share.

Slater and Narver (1994) investigate the moderating role of the competitive environment in the MO-firm performance relationship. Although there is very limited support for the moderator role of environment, $\mathrm{MO}$ is still positively related to subjective ROA, sales growth, and new product success. Therefore, they suggest that it is better for companies to invest in becoming market oriented while the environment is somewhat munificent than to wait until the environment has grown hostile, if it is not pertinent.

Homburg and Pflesser (2000) develop a multilayer scale to measure the different layers of market-oriented organizational culture. They also analyze relationships among the different components of market-oriented culture. The results show a positive effect of marketoriented culture on subjective market performance and a stronger relationship in highly dynamic markets.

Matsuno and Mentzer (2000) empirically examine the role of business types as a moderator in the MO-firm performance relationship. The findings support the moderating effect of business strategy types on the strength of the relationship between MO and business performance. They measure business performance by subjective market-share growth, relative sales growth, new product sales as a percentage of total sales, and return on investment (ROI).

Grewal and Tansuhaj (2001) investigate the role of MO and strategic flexibility in helping Thai firms manage the Asian economic crises. The results show that after crisis, MO has an adverse effect on firm performance, which they measure by subjective satisfaction with the goals of ROI, sales, profits, and growth. Demand and technological uncertainty moderate 
the MO-performance relationship. In contrast, strategic flexibility has a positive influence on firm performance after a crisis, which is also moderated by environmental variables, including competitive intensity, demand, and technological uncertainty. Therefore, $\mathrm{MO}$ and strategic flexibility complement each other in their ability to help firms manage various environmental conditions.

Matsuno, Mentzer, and Özsomer (2002) study the direct and indirect structural influences of entrepreneurial proclivity and MO on business performance. The findings indicate that entrepreneurial proclivity has not only a positive, direct relationship on MO but also an indirect, positive effect on MO by reducing departmentalization. Entrepreneurial proclivity's performance influence is positive when mediated by MO but is negative or nonsignificant when unmediated by MO.

Noble, Sinha, and Kumar (2002) explore the relative performance effects of MO by using a longitudinal approach based on letters to shareholders in corporate annual reports. At the same time, the relative effects of alternative strategic orientations, such as production and selling orientation, reflect different managerial priorities for the firm. The findings suggest that competition orientation and national brand focus are positively related to objective ROA and return on sales (ROS).

The unclear relationship between $\mathrm{MO}$ and performance has lead many scholars to search for potential mediators and moderators in order to explain the unstable relationship. This search has brought about the third MO research stream. 


\subsubsection{Implementation of Market Orientation}

The third research stream addresses how to implement or configure MO in complex management practices. Theoretically, firms should implement MO to fit with the external and internal environments in order to achieve superior firm performance. Fit between the marketing strategy and external environment means that firms should design the marketing strategy or a set of marketing activities to match with the general, industry, and firm environments (e.g., Appiah-Adu 1997; Cadogan, Diamantopoulos, and Siguaw 2002; Jaworski and Kohli 1993; Pelham 1997b; Perry and Shao 2002). Fit between MO and internal environment means that marketing strategy and market activities should be congruent with business strategy (e.g., Mavondo 1999); corporate strategy type (Matsuno and Mentzer 2000; Noble, Sinha, and Kumar 2002); organizational strategy (Ruekert 1992); strategy flexibility (Grewal and Tansuhaj 2001); strategy formulation (Arnould and Wallendorf 1994); marketing strategy process (Tadepalli and Avila 1999); implementation strategies (Cravens 1998); market and firm structure (Pelham and Wilson 1996); and functional strategies, such as human resource management strategy (Harris and Ogbonna 2001), technology strategy, administration strategy, manufacture strategy, and distribution channel (Baker, Simpson, and Siguaw 1999; Langerak 2001; Siguaw, Simpson, and Baker 1998) (see table 2.2).

In the third research stream, the most recent influential research is from the innovation perspective (Grewal and Tansuhaj 2001; Han, Kim, and Sirvastava 1998; Hurley and Hult 1998) and the learning perspective (Baker and Sinkula 1999a, b; Baker and Sinkula 2002; Celuch, Kasouf, and Peruvemba 2002; Farrell 2000; Farrell and Oczkowski 2002; Slater and Narver 1995). In the following section, I review the literature about MO and new product innovation. 


\subsubsection{The Relationship Between Market Orientation and New Product}

\section{Innovation}

Among the literature on the MO-performance relationship, studies typically link MO with either new product success (e.g., Atuahene-Gima 1995, 1996; Im and Workman 2004;

Lukas and Ferrell 2000) or firm performance (e.g., Grewal and Tansuhaj 2001; Homburg and Pflesser 2000; Jaworski and Kohli 1993). Although some studies examine the links between $\mathrm{MO}$ and new product success and between $\mathrm{MO}$ and firm performance at the same time (e.g., Appiah-Adu 1997; Appiah-Adu and Ranchhod 1998; Greenley 1995; Pelham and Wilson 1996; Slater and Narver 1994), few studies specify the relationship between new product success and firm performance. The relationship among MO, new product success, and firm performance may be explained by the source-position-performance framework of Day and Wensley (1988). Some studies suggest that MO may lead to business position advantage through new product success, and in turn new product success may positively influence firms' sales growth and market share (Langerak, Hultink, and Robben 2004; Pelham and Wilson 1996). Several other studies also provide evidence from the innovation perspective, arguing that innovation may link MO with firm performance as a mediator (Han, Kim, and Srivastava 1998; Matear et al. 2002; Noble, Sinha, and Kumar 2002). If new product success is the key mediator for providing a positional advantage to link $\mathrm{MO}$ with firm performance, it is very important to first understand the relationship between $\mathrm{MO}$ and new product success.

Although it has been suggested that MO is a mechanism for providing new ideas and motivation to respond to the environment (Hurley and Hult 1998), the empirical results about the MO-new product innovation relationship are mixed (see tables 2.1 and 2.3). Some studies 
Table 2. 1 Summary of Empirical Studies on the Relationship Between MO and Business Performance

\begin{tabular}{|c|c|c|c|c|}
\hline \multirow{3}{*}{$\begin{array}{c}\text { Empirical } \\
\text { Study }\end{array}$} & \multirow{3}{*}{ Independent Variables } & \multicolumn{3}{|c|}{ Dependent Variable } \\
\hline & & \multirow{2}{*}{$\begin{array}{l}\text { Findings of } \\
\text { MO on } \\
\text { Attitude }\end{array}$} & \multicolumn{2}{|c|}{ Findings of MO on Performance } \\
\hline & & & Subjective Measures & $\begin{array}{l}\text { Objective } \\
\text { Measures }\end{array}$ \\
\hline $\begin{array}{l}\text { Narver and } \\
\text { Slater (1990), } \\
\text { U.S. }\end{array}$ & $\mathrm{MO} \rightarrow$ firm performance & & $\begin{array}{l}\text { ROA: } \\
\text { Commodity business: ROA (U- } \\
\text { Shape relationship), } \\
\text { Noncommodity business: ROA }(+)\end{array}$ & \\
\hline $\begin{array}{l}\text { Jaworski and } \\
\text { Kohli (1993), } \\
\text { U.S. }\end{array}$ & $\begin{array}{l}\text { Antecedents } \rightarrow \mathrm{MO}, \mathrm{MO} \mathrm{X} \text { moderators } \rightarrow \\
\text { consequences } \rightarrow \text { firm performance } \\
\text { MO antecedents: Top management emphasis, top } \\
\text { management risk aversion, interdepartmental conflict, } \\
\text { interdepartmental connectedness, formalization, } \\
\text { centralization, departmentalization, reward system } \\
\text { orientation } \\
\text { MO consequences: product quality, competitive } \\
\text { intensity, buyer power, supplier power, entry barriers, } \\
\text { substitutes } \\
\text { Moderators: market turbulence }(0) \text {, competitive } \\
\text { intensity }(0) \text {, and technological turbulence }(0)\end{array}$ & $\begin{array}{l}\text { Organizational } \\
\text { commitment }(+) \\
\text { Esprit de corps } \\
(+)\end{array}$ & Overall performance $(+): 2$ items & $\begin{array}{l}\text { Market share } \\
(0)\end{array}$ \\
\hline $\begin{array}{l}\text { Siguaw, Brown, } \\
\text { and Widing } \\
\text { (1994), U.S. }\end{array}$ & $\begin{array}{l}\mathrm{MO}, \text { customer orientation, difference between } \mathrm{MO} \text { and } \\
\text { customer orientation } \rightarrow \text { role conflict, role ambiguity } \rightarrow \\
\text { job satisfaction and organizational commitment }\end{array}$ & $\begin{array}{l}\text { Sales behavior: } \\
\text { customer } \\
\text { orientation }(+), \\
\text { role conflict }(-) \text {, } \\
\text { role ambiguity } \\
(-), \text { job } \\
\text { satisfaction }(-) \text {, } \\
\text { organizational } \\
\text { commitment }(-)\end{array}$ & & \\
\hline $\begin{array}{l}\text { Slater and } \\
\text { Narver (1994), } \\
\text { U.S. }\end{array}$ & $\begin{array}{l}\mathrm{MO}, \mathrm{MO} \times \text { moderators } \rightarrow \text { firm performance } \\
\text { Emphasis moderators: market growth, buyer power, } \\
\text { competitor concentration, competitor hostility } \\
\text { Strength moderators: market turbulence }(- \text { on ROA }), \\
\text { technological turbulence }(- \text { on new product success), } \\
\text { competitive hostility, market growth ( }- \text { on sales growth) }\end{array}$ & & $\begin{array}{l}\text { ROA }(+) \\
\text { Sales growth }(+) \\
\text { New product success }(+)\end{array}$ & \\
\hline
\end{tabular}




\begin{tabular}{|c|c|c|}
\hline $\begin{array}{l}\text { Atuahene-Gima } \\
\text { (1995), Australia }\end{array}$ & $\begin{array}{l}\text { MO, MO } \times \text { moderators } \rightarrow \text { NPD process activities, } \\
\text { New product performance } \\
\text { Moderators: degree of product newness to customers } \\
\text { and the firm }(-) \text {, intensity of market competition } \\
(+) \text {,hostility of industry environment }(+) \text {,stage of } \\
\text { product life cycle at which new product was } \\
\text { introduced }(-)\end{array}$ & $\begin{array}{l}\text { NPD activities }(+) \text { : proficiency of } \\
\text { product development activity, } \\
\text { proficiency of launch activity, } \\
\text { service quality, product advantage, } \\
\text { marketing synergy and teamwork; } \\
\text { NPP: Market level }(+) \text {, project } \\
\text { level }(+)\end{array}$ \\
\hline $\begin{array}{l}\text { Greenley (1995), } \\
\text { U.K. }\end{array}$ & $\begin{array}{l}\text { Antecedents } \rightarrow \mathrm{MO}, \mathrm{MO} \times \text { moderators } \rightarrow \text { firm } \\
\text { performance } \\
\text { Antecedents: Relative size, relative cost, ease of } \\
\text { market entry, customer power, competitor } \\
\text { concentration, competitor hostility } \\
\text { Moderators: market turbulence }(- \text { on ROI), market } \\
\text { growth }(0), \text { technological change }(- \text { on new product } \\
\text { success rate), }\end{array}$ & $\begin{array}{l}\text { ROI }(0) \\
\text { New product success rate }(0) \\
\text { Sales growth }(0)\end{array}$ \\
\hline $\begin{array}{l}\text { Atuahene-Gima } \\
\text { (1996), Australia }\end{array}$ & $\begin{array}{l}\mathrm{MO} \rightarrow \text { innovation consequences } \rightarrow \text { firm performance } \\
\text { Consequences: product newness to customers }(-), \\
\text { product newness to firm }(0) \text {, product advantage }(+), \\
\text { innovation-marketing fit }(+) \text {, innovation-technology fit } \\
(0) \text {, teamwork }(+)\end{array}$ & $\begin{array}{l}\text { Market success of product } \\
\text { innovation: } 4 \text { items }(0) \\
\text { Project impact performance: } 3 \\
\text { items }(+)\end{array}$ \\
\hline $\begin{array}{l}\text { Pelham and Wilson } \\
(1996), \text { U.S. }\end{array}$ & $\begin{array}{l}\text { Antecedents } \rightarrow \mathrm{MO} \rightarrow \text { business position } \rightarrow \\
\text { profitability } \\
\text { Antecedents: strategy: Innovation /differentiation } \\
\text { strategy, low-cost strategy; firm structure: } \\
\text { decentralization, formalization, coordination, product } \\
\text { differentiation, control systems; market } \\
\text { environment: market dynamism, competitive } \\
\text { intensity. }\end{array}$ & $\begin{array}{l}\text { Business position variables: } \\
\text { Relative product quality: } 1 \text { item } \\
(+) \\
\text { New product success: } 2 \text { items }(+) \\
\text { Growth/share: } 3 \text { items }(0), \\
\text { Profitability: } 5 \text { items }(+) .\end{array}$ \\
\hline $\begin{array}{l}\text { Pitt, Caruana, and } \\
\text { Berthon (1996), } \\
\text { Europe }\end{array}$ & $\mathrm{MO} \rightarrow$ business performance & $\begin{array}{l}\text { Overall impression }(+) \\
\text { Business performance }(+)\end{array}$ \\
\hline
\end{tabular}




\begin{tabular}{|c|c|c|c|c|}
\hline $\begin{array}{l}\text { Appiah-Adu } \\
\text { (1997), U.K. }\end{array}$ & $\begin{array}{l}\text { MO } \rightarrow \text { business performance } \\
\text { Moderators: market turbulence ( }- \text { on ROI), } \\
\text { technological turbulence }(0) \text {, competitive intensity ( }- \text { on } \\
\text { new product success rate), market growth ( }- \text { on sales } \\
\text { growth) } \\
\text { Control variables: relative product quality, relative size, } \\
\text { relative operating cost }\end{array}$ & & $\begin{array}{l}\text { New product success }(+) \\
\text { Sales growth }(+) \\
\text { ROI }(+)\end{array}$ & \\
\hline $\begin{array}{l}\text { Bhuian (1997), } \\
\text { Saudi Arabia }\end{array}$ & $\mathrm{MO} \rightarrow$ business performance & & & $\begin{array}{l}\text { Three objective } \\
\text { performances: } \\
\text { ROA (-), ROE } \\
(-), \text { sales per } \\
\text { employee }(-)\end{array}$ \\
\hline $\begin{array}{l}\text { Appiah-Adu and } \\
\text { Ranchhod (1998), } \\
\text { U.K. }\end{array}$ & $\begin{array}{l}\mathrm{MO} \rightarrow \text { business performance } \\
\text { Control variables: relative size, relative cost, relative } \\
\text { product/service quality, time of market entry, competitor } \\
\text { concentration, market turbulence, competitive intensity, } \\
\text { technological turbulence }\end{array}$ & & $\begin{array}{l}\text { New product success }(0) \\
\text { Market share }(+) \\
\text { Profit margins }(+) \\
\text { Overall performance }(+)\end{array}$ & \\
\hline $\begin{array}{l}\text { Chang and Chen } \\
\text { (1998), Taiwan }\end{array}$ & $\begin{array}{l}\mathrm{MO} \rightarrow \text { service quality } \rightarrow \text { business performance } \\
\text { Mediator: service quality } \\
\text { Control variables: conglomerate status, respondent } \\
\text { seniority, market size, market share, sales volume }\end{array}$ & & $\begin{array}{l}\text { Relative business } \\
\text { profitability }(+)\end{array}$ & \\
\hline $\begin{array}{l}\text { Egeren and } \\
\text { O’Connor (1998), } \\
\text { U.S. }\end{array}$ & $\begin{array}{l}\text { Antecedents } \rightarrow \mathrm{MO} \rightarrow \text { business performance } \\
\text { Antecedents: Cohesiveness }(+) \text {, communications }(-), \\
\text { munificence }(+) \text {, dynamism }(+) \text {, heterogeneity }(-)\end{array}$ & & $\begin{array}{l}\text { Organizational performance } \\
(+)\end{array}$ & $\begin{array}{l}\text { Mentioned, but } \\
\text { not clear what it } \\
\text { is. }\end{array}$ \\
\hline $\begin{array}{l}\text { Gray et al. (1998), } \\
\text { New Zealand }\end{array}$ & $\begin{array}{l}\mathrm{MO} \rightarrow \text { company performance } \\
\text { Control variables: production orientation, sales } \\
\text { orientation, marketing orientation, societal orientation }\end{array}$ & & $\begin{array}{l}\text { Brand awareness }(+) \\
\text { Customer satisfaction }(+) \\
\text { Loyalty }(+)\end{array}$ & ROI (-) \\
\hline $\begin{array}{l}\text { Han, Kim, and } \\
\text { Sirvastava (1998), } \\
\text { U.S. }\end{array}$ & $\begin{array}{l}\text { MO, MO } \times \text { moderators } \rightarrow \text { innovation } \rightarrow \text { organizational } \\
\text { performance } \\
\text { Mediator: innovation (wrong conclusion, should be } 0) \\
\text { Moderators: } \\
\text { technological turbulence ( }+ \text { on innovation) }\end{array}$ & & $\begin{array}{l}\text { Innovation }(+) \\
\text { Relative growth }(0) \\
\text { Profitability }(0)\end{array}$ & $\begin{array}{l}\text { Net income } \\
\text { growth }(0) \\
\text { ROA }(0)\end{array}$ \\
\hline $\begin{array}{l}\text { Horng and Chen } \\
\text { (1998), Taiwan }\end{array}$ & $\begin{array}{l}\mathrm{MO} \rightarrow \text { business performance } \\
\text { Antecedents: Top management variables: marketing } \\
\text { experience/education, leadership style, emphasis on } \\
\text { market orientation, organizational system variables: } \\
\text { reward system, management's capability, training }\end{array}$ & $\begin{array}{l}\text { Organizationa } \\
1 \text { commitment } \\
(+), \\
\text { Esprit Corps } \\
(+)\end{array}$ & Overall performance $(+)$ & \\
\hline
\end{tabular}




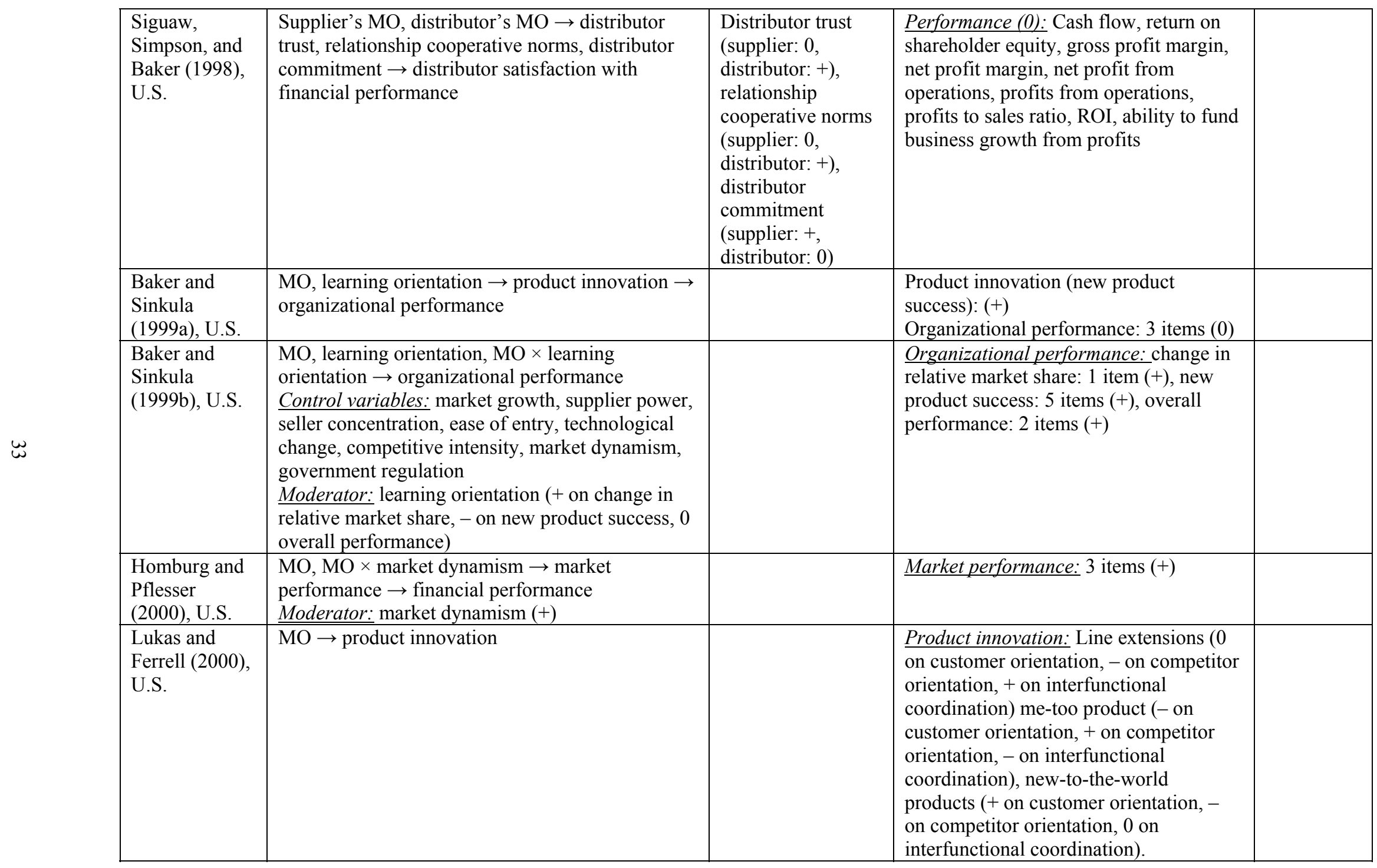




\begin{tabular}{|c|c|c|c|}
\hline $\begin{array}{l}\text { Matsuno and } \\
\text { Mentzer } \\
(2000), \text { U.S. }\end{array}$ & $\begin{array}{l}\text { MO, } \mathrm{MO} \times \text { moderators } \rightarrow \text { business performance } \\
\text { Moderator: business strategy type }(+): \\
\text { prospectors, analyzers, reactors }\end{array}$ & $\begin{array}{l}\text { Business performance: } \text { market share growth, } \\
\text { relative sales growth, new product sales as a } \\
\text { percentage of total sales, ROI }\end{array}$ & \\
\hline $\begin{array}{l}\text { Grewal and } \\
\text { Tansuhaj } \\
\text { (2001), } \\
\text { Thailand }\end{array}$ & $\begin{array}{l}\mathrm{MO}, \text { strategic flexibility }(\mathrm{SF}), \mathrm{MO} \times \text { moderators, } \\
\mathrm{SF} \times \text { moderators } \rightarrow \text { performance after crisis } \\
\text { Moderators: competitive dynamism }(- \text { for } \mathrm{MO},+ \\
\text { for } \mathrm{SF}), \text { demand uncertainty }(+ \text { for } \mathrm{MO},- \text { for } \mathrm{SF}) \text {, } \\
\text { technological uncertainty }(- \text { for } \mathrm{MO},- \text { for } \mathrm{SF})\end{array}$ & $\begin{array}{l}\text { Performance (-): Satisfaction with ROI goals, } \\
\text { sales goals, profit goals, and growth goals. }\end{array}$ & \\
\hline $\begin{array}{l}\text { Hult and } \\
\text { Ketchen } \\
(2001), \text { U.S. }\end{array}$ & $\begin{array}{l}\text { MO, entrepreneurship, innovativeness, } \\
\text { organizational learning } \rightarrow \text { positional advantage } \rightarrow \\
\text { performance }\end{array}$ & & $\begin{array}{l}\text { 5-year average } \\
\text { change in ROI } \\
(+), 5 \text {-year } \\
\text { percentage } \\
\text { change in } \\
\text { income }(+), 5- \\
\text { year percentage } \\
\text { change in stock } \\
(+)\end{array}$ \\
\hline $\begin{array}{l}\text { Kahn }(2001) \text {, } \\
\text { U.S. }\end{array}$ & MO, interdepartmental integration $\rightarrow$ Performance & $\begin{array}{l}\text { Product development performance ( }+ \text { marketing } \\
\text { managers; } 0 \text { for manufacturing and R\&D } \\
\text { managers) } \\
\text { Product management performance }(+ \text { for } \\
\text { marketing and manufacturing managers, } 0 \text { for } \\
\text { R\&D managers) }\end{array}$ & \\
\hline $\begin{array}{l}\text { Langerak } \\
(2001), \text { the } \\
\text { Netherlands }\end{array}$ & $\begin{array}{l}\text { Self-reports downstream MO, customer reports } \\
\text { downstream MO, self-reports upstream MO, } \\
\text { supplier upstream } \mathrm{MO} \rightarrow \text { self-reports business } \\
\text { performance } \\
\text { Control variables: } 27 \text { items }\end{array}$ & $\begin{array}{l}\text { Sales growth }(+) \text {, profit }(+), \text { NPD success }(+), \\
\text { ROI }(+)\end{array}$ & \\
\hline $\begin{array}{l}\text { Raju and } \\
\text { Lonial (2001), } \\
\text { U.S. }\end{array}$ & Quality context $\rightarrow \mathrm{MO} \rightarrow$ performance & $\begin{array}{l}\text { Performance }(+) \text { : Financial performance: new } \\
\text { profits, ROI, cash flow from operations, ROA, } \\
\text { profit-to-revenue ratio; Market/product } \\
\text { development: new product/service } \\
\text { development, investments in R\&D aimed at new } \\
\text { innovation, capacity to develop a unique } \\
\text { competitive profile, market development; } \\
\text { quality outcomes: mortality and morbidity rate, } \\
\text { service quality as perceived by customers, cost } \\
\text { per adjusted discharge, employee turnover }\end{array}$ & \\
\hline
\end{tabular}




\begin{tabular}{|c|c|c|c|}
\hline $\begin{array}{l}\text { Gainer and } \\
\text { Padanyi } \\
(2002) \text {, } \\
\text { Canada }\end{array}$ & $\begin{array}{l}\text { MO activities } \rightarrow \text { MO culture } \rightarrow \text { growth in } \\
\text { customer satisfaction, growth in reputation } \rightarrow \\
\text { growth in resources }(+)\end{array}$ & $\begin{array}{l}\text { Nonprofit organizational effectiveness: } \\
\text { Market-oriented culture }(+) \text {, growth in customer } \\
\text { satisfaction }(+) \text {, growth in reputation }(+) \text {, }\end{array}$ & \\
\hline $\begin{array}{l}\text { Matear et al. } \\
(2002) \text {, } \\
\text { New Zealand }\end{array}$ & $\begin{array}{l}\mathrm{MO} \rightarrow \text { innovation } \rightarrow \text { performance } \\
\text { Or: } \mathrm{MO} \times \text { innovation }(0) \rightarrow \text { performance }\end{array}$ & $\begin{array}{l}\text { Innovation: }(+) \\
\text { Performance: } 2 \text { items: financial performance } \\
(+), \text { market performance }(+)\end{array}$ & \\
\hline $\begin{array}{l}\text { Matsuno, } \\
\text { Mentzer, and } \\
\text { Özsomer } \\
\text { (2002), U.S. }\end{array}$ & $\begin{array}{l}\text { Entrepreneurial proclivity } \rightarrow \text { organizational } \\
\text { structure } \rightarrow \mathrm{MO} \rightarrow \text { business performance } \\
\text { Antecedents: Entrepreneurial proclivity }\end{array}$ & $\begin{array}{l}\text { Market share }(+) \text {, percentage of new product } \\
\text { sales to total sales }(+), \text { ROI }(+)\end{array}$ & \\
\hline $\begin{array}{l}\text { Noble, Sinha, } \\
\text { and Kumar } \\
\text { (2002), U.S. }\end{array}$ & $\begin{array}{l}\text { MO, strategic orientation } \rightarrow \text { organizational } \\
\text { learning, innovativeness } \rightarrow \text { firm performance } \\
\text { Mediators: organizational learning, innovativeness }\end{array}$ & & $\begin{array}{l}\text { ROA (+ only for } \\
\text { competitor } \\
\text { orientation } \\
\text { dimension), ROS } \\
\text { (+only for } \\
\text { competitor } \\
\text { orientation } \\
\text { dimension) } \\
\end{array}$ \\
\hline $\begin{array}{l}\text { Perry and Shao } \\
\text { (2002), U.S. }\end{array}$ & $\begin{array}{l}\mathrm{MO}, \mathrm{MO} \times \text { moderators } \rightarrow \text { market performance } \rightarrow \\
\text { financial performance } \\
\text { Control variables: competitive dynamism, country } \\
\text { economic group, traditional competition, specialty } \\
\text { competition. } \\
\text { Moderators: competitive dynamism ( } 0) \text {, trading } \\
\text { competition } \\
(+ \text { on qualitative performance), specialty } \\
\text { competition }(0)\end{array}$ & $\begin{array}{l}\text { Qualitative performance (0) } \\
\text { Quantitative performance (0) }\end{array}$ & \\
\hline $\begin{array}{l}\text { Agarwal, } \\
\text { Erramilli, and } \\
\text { Dev (2003), } \\
\text { U.S. }\end{array}$ & $\begin{array}{l}\mathrm{MO} \rightarrow \text { innovation } \rightarrow \text { judgmental performance } \\
\rightarrow \text { objective performance } \\
\text { Mediators: innovation, judgmental performance }\end{array}$ & $\begin{array}{l}\text { Innovation: }(+) \\
\text { Judgmental performance }(+) \text { : service quality, } \\
\text { customer satisfaction, employee satisfaction }\end{array}$ & $\begin{array}{l}\text { Objective } \\
\text { performance }(0 \\
\text { direct, }+ \\
\text { indirect): } \\
\text { Occupancy rate, } \\
\text { gross operating } \\
\text { profit, market } \\
\text { share }\end{array}$ \\
\hline
\end{tabular}




\begin{tabular}{|c|c|c|c|c|}
\hline $\begin{array}{l}\text { Farrelly and } \\
\text { Quester (2003), } \\
\text { Australia }\end{array}$ & $\begin{array}{l}\text { Property } \mathrm{MO} \rightarrow \text { collaborative communication } \rightarrow \text { property } \\
\text { MO perceived by sponsor, sponsor } \mathrm{MO} \rightarrow \text { sponsor trust } \\
\rightarrow \text { sponsor commitment }\end{array}$ & $\begin{array}{l}\text { sponsor trust } \\
(+), \text { sponsor } \\
\text { commitment }(+)\end{array}$ & & \\
\hline $\begin{array}{l}\text { Hooley et al. } \\
\text { (2003), Central } \\
\text { Europe }\end{array}$ & $\begin{array}{l}\text { Market life-cycle stage, changing customer requirements, } \\
\text { technological change, degree of competition, strategic } \\
\text { priorities business approach, marketing strategy variables } \\
\text { (market targeting approach, service positioning, price } \\
\text { positioning, strategy elements } \rightarrow \mathrm{MO} \rightarrow \text { performance }\end{array}$ & $\begin{array}{l}\text { Customer } \\
\text { satisfaction }\end{array}$ & $\begin{array}{l}\text { Performance }(+) \text { : profit, sales volume, } \\
\text { market share, ROI }\end{array}$ & $\mathrm{ROI}(+)$ \\
\hline $\begin{array}{l}\text { Krepapa et al. } \\
(2003) \text {, country } \\
\text { not clear }\end{array}$ & $\begin{array}{l}\text { MO perceived by customer, gap of MO between service } \\
\text { provider perception and customer perception } \rightarrow \\
\text { satisfaction }\end{array}$ & $\begin{array}{l}\text { Customer } \\
\text { satisfaction }(+ \\
\text { for } \\
\text { MO_customer, } \\
\text { - for MO_Gap) }\end{array}$ & & \\
\hline $\begin{array}{l}\text { Pulendran, } \\
\text { Speed, and } \\
\text { Widing (2003), } \\
\text { Australia }\end{array}$ & $\begin{array}{l}\text { Marketing planning }=\mathrm{MP}(\text { comprehensiveness, rationality, } \\
\text { politicality, interaction, formalization), MP } \times \text { market } \\
\text { turbulence }(+), \mathrm{MP} \times \text { technological turbulence }(+), \mathrm{MP} \times \\
\text { competitive intensity }(0) \rightarrow \mathrm{MO} \rightarrow \text { performance } \\
\text { Mediator: MO }\end{array}$ & & Performance: 5 items $(+)$ & \\
\hline $\begin{array}{l}\text { Sin et al. } \\
(2003), \text { China } \\
\text { and Hong Kong }\end{array}$ & Economic ideology $\rightarrow \mathrm{MO} \rightarrow$ performance & & $\begin{array}{l}\text { Overall performance: }(+) \text { : sales } \\
\text { growth, customer retention, } \mathrm{ROI}, \\
\text { market share }\end{array}$ & \\
\hline $\begin{array}{l}\text { Im and } \\
\text { Workman } \\
(2004), \text { U.S. }\end{array}$ & $\begin{array}{l}\mathrm{MO} \rightarrow \mathrm{NP} \text { and MP creativity } \rightarrow \mathrm{NPP} \\
\underline{\text { Mediator: }} \text { NP and MP creativity }\end{array}$ & & $\begin{array}{l}\text { New product creativity }(+) \text { : novelty } \\
\text { and meaningfulness; Marketing } \\
\text { program creativity }(+) \text { : novelty and } \\
\text { meaningfulness; } N P P(0) \text { : market, } \\
\text { financial, and overall assessment } \\
\text { measures }\end{array}$ & \\
\hline $\begin{array}{l}\text { Langerak, } \\
\text { Hultink, and } \\
\text { Robben (2004), } \\
\text { the Netherlands }\end{array}$ & $\begin{array}{l}\mathrm{MO} \rightarrow \text { product advantage, market testing, launch } \\
\text { budgeting, launch strategy, launch tactics } \rightarrow \mathrm{NPP} \rightarrow \text { firm } \\
\text { performance }\end{array}$ & & $\begin{array}{l}\frac{\text { A second-order scale with } 5 \text { subscales }}{(0): \text { market level, financial, customer }} \\
\text { acceptance, product level, timing } \\
\text { measures of NPD success. }\end{array}$ & \\
\hline $\begin{array}{l}\text { Zhou, Yim, and } \\
\text { Tse }(2005) \text {, } \\
\text { China }\end{array}$ & $\begin{array}{l}\text { MO, technology orientation, } \mathrm{EO} \rightarrow \text { technology-based } \\
\text { innovation, market-based innovation } \rightarrow \text { firm performance, } \\
\text { product performance } \\
\text { Mediator: technology-based innovation, market-based } \\
\text { innovation }\end{array}$ & & $\begin{array}{l}\text { Technology-based innovation }(+), \\
\text { market-based innovation }(-), \\
\text { innovations on firm performance }(+), \\
\text { innovations on product performance } \\
(+)\end{array}$ & \\
\hline
\end{tabular}




\section{Table 2. 2 Summary of Previous Literature on MO Implementation}

\begin{tabular}{|c|c|c|c|}
\hline Topic & & Article Name & Content \\
\hline \multirow{13}{*}{$\begin{array}{l}\text { How to develop } \\
\text { or implement MO }\end{array}$} & $\begin{array}{l}\text { Organization } \\
\text { strategy }\end{array}$ & Ruekert (1992) & $\begin{array}{l}\text { Individual attitudes toward jobs; broader organizational processes (e.g., recruiting, } \\
\text { training, compensation) }\end{array}$ \\
\hline & Business strategy & $\begin{array}{l}\text { Appiah-Adu and } \\
\text { Blankson (1998) }\end{array}$ & African study; a positive influence of SAP induces strategies on the MO level \\
\hline & Strategic type & Lukas (1999) & Differences in MO degree reveal a distinctive pattern of strategy \\
\hline & $\begin{array}{l}\text { Organization } \\
\text { ability }\end{array}$ & Day (1994) & Organizational capabilities \\
\hline & $\begin{array}{l}\text { Accounting } \\
\text { systems }\end{array}$ & $\begin{array}{l}\text { Goebel, Marshall } \\
\text { and Locander } \\
(1998)\end{array}$ & $\begin{array}{l}\text { U.S.; actively based costing is useful to marketers at various levels of decision } \\
\text { making in market-oriented activities }\end{array}$ \\
\hline & Innovation & $\begin{array}{l}\text { Atuahene-Gima } \\
\text { (1996); Hurley and } \\
\text { Hult (1998) }\end{array}$ & MO-innovation \\
\hline & Innovation & $\begin{array}{l}\text { Han, Kim, and } \\
\text { Srivastava (1998); }\end{array}$ & Mediating role of innovation in the $\mathrm{MO}$-performance relationship \\
\hline & $\begin{array}{l}\text { Organizational } \\
\text { learning }\end{array}$ & $\begin{array}{l}\text { Slater and Narver } \\
\text { (1995); Hurley and } \\
\text { Hult (1998); } \\
\text { Morgan, Katsikeas, } \\
\text { and Appiah-Adu } \\
\text { (1998) }\end{array}$ & \\
\hline & $\begin{array}{l}\text { Organization } \\
\text { commitment }\end{array}$ & $\begin{array}{l}\text { Caruana, } \\
\text { Ramaseshan, and } \\
\text { Ewing (1999) }\end{array}$ & $\begin{array}{l}\text { Australian sample from public sector; the mediating role of organization } \\
\text { commitment in the MO-performance relationship }\end{array}$ \\
\hline & $\begin{array}{l}\text { Marketing strategy } \\
\text { process }\end{array}$ & $\begin{array}{l}\text { Tadepalli and } \\
\text { Avila (1999) }\end{array}$ & $\begin{array}{l}\text { Conceptual paper; how marketing strategy is put together in an organizational } \\
\text { environment }\end{array}$ \\
\hline & $\begin{array}{l}\text { Developing an } \mathrm{MO} \\
\text { culture }\end{array}$ & $\begin{array}{l}\text { Harris and } \\
\text { Ogbonna (1999; } \\
\text { 2000) }\end{array}$ & Five principal areas ignored or insufficiently addressed \\
\hline & Creating an $\mathrm{MO}$ & $\begin{array}{l}\text { Narver, Slater, and } \\
\text { Tietje (1998) }\end{array}$ & \\
\hline & $\begin{array}{l}\text { Barriers to develop } \\
\text { MO }\end{array}$ & Harris (1999) & $\begin{array}{l}\text { Conceptual paper; capabilities of employees, organizational structure and systems, } \\
\text { people-led approach: belief, understanding and organizational members on } \mathrm{MO} \text {, the } \\
\text { moderating role of power and control }\end{array}$ \\
\hline
\end{tabular}




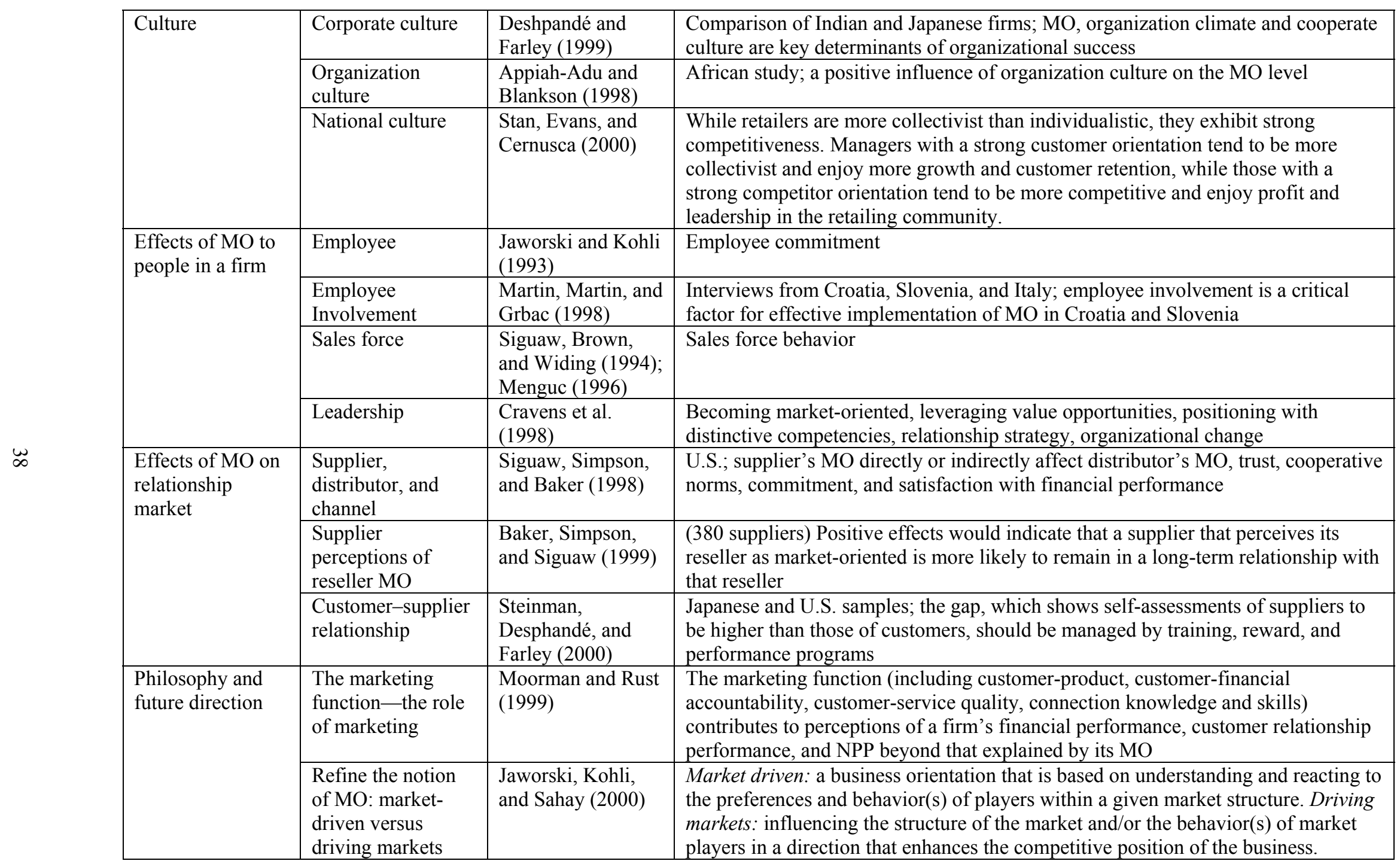


Table 2. 3 Summary of Empirical Studies on the Relationship Between MO and Innovation/NPP

\begin{tabular}{|c|c|c|c|c|}
\hline \multirow[t]{3}{*}{ Empirical Study } & \multirow[t]{3}{*}{ Independent Variables } & \multicolumn{3}{|c|}{ Dependent Variable } \\
\hline & & \multirow{2}{*}{$\begin{array}{c}\text { Findings of } \\
\text { MO on } \\
\text { Attitude }\end{array}$} & \multicolumn{2}{|l|}{ Findings of MO on Performance } \\
\hline & & & Subjective Measures & $\begin{array}{l}\text { Objective } \\
\text { Measures }\end{array}$ \\
\hline $\begin{array}{l}\text { Slater and Narver } \\
\text { (1994), U.S. }\end{array}$ & $\begin{array}{l}\text { MO, MO } \times \text { moderators } \rightarrow \text { firm performance } \\
\text { Emphasis moderators: market growth, buyer } \\
\text { power, competitor concentration, competitor } \\
\text { hostility } \\
\text { Strength moderators: market turbulence }(- \text { on } \\
\text { ROA), technological turbulence (- on new } \\
\text { product success), competitive hostility, market } \\
\text { growth (- on sales growth) }\end{array}$ & & $\begin{array}{l}\text { ROA }(+) \\
\text { Sales growth }(+) \\
\text { New product success }(+)\end{array}$ & \\
\hline $\begin{array}{l}\text { Atuahene-Gima } \\
\text { (1995), Australia }\end{array}$ & $\begin{array}{l}\text { MO, MO } \times \text { moderators } \rightarrow \text { NPD process } \\
\text { activities, NPP } \\
\text { Moderators: degree of product newness to } \\
\text { customers and firm }(-) \text {,intensity of market } \\
\text { competition }(+) \text { and hostility of industry } \\
\text { environment }(+) \text {,stage of product life cycle at } \\
\text { which new product was introduced }(-)\end{array}$ & & $\begin{array}{l}\text { NPD activities }(+): \text { proficiency of product } \\
\text { development activity, proficiency of launch } \\
\text { activity, service quality, product advantage, } \\
\text { marketing synergy and teamwork; } \\
\text { NPP: market level }(+) \text {, project level }(+)\end{array}$ & \\
\hline $\begin{array}{l}\text { Greenley (1995), } \\
\text { U.K. }\end{array}$ & $\begin{array}{l}\text { Antecedents } \rightarrow \mathrm{MO}, \mathrm{MO} \times \text { moderators } \rightarrow \\
\text { firm performance } \\
\text { Antecedents: relative size, relative cost, ease } \\
\text { of market entry, customer }] \stackrel{\omega}{\omega} \text { competitor } \\
\text { concentration, competitor hostillty } \\
\text { Moderators: market turbulence (- on ROI), } \\
\text { market growth }(0) \text {, technological change }(- \text { on } \\
\text { new product success rate), }\end{array}$ & & $\begin{array}{l}\text { ROI }(0) \\
\text { New product success rate }(0) \\
\text { Sales growth }(0)\end{array}$ & \\
\hline $\begin{array}{l}\text { Atuahene-Gima } \\
\text { (1996), Australia }\end{array}$ & $\begin{array}{l}\mathrm{MO} \rightarrow \text { consequences } \rightarrow \text { firm performance } \\
\text { Consequences: product newness to customers } \\
(-), \text { product newness to firm }(0), \text { product } \\
\text { advantage }(+), \text { innovation-marketing fit }(+), \\
\text { innovation-technology fit }(0), \text { teamwork }(+)\end{array}$ & & $\begin{array}{l}\text { Market success of product innovation: } 4 \\
\text { items }(0) \\
\text { Project impact performance: } 3 \text { items }(+)\end{array}$ & \\
\hline
\end{tabular}




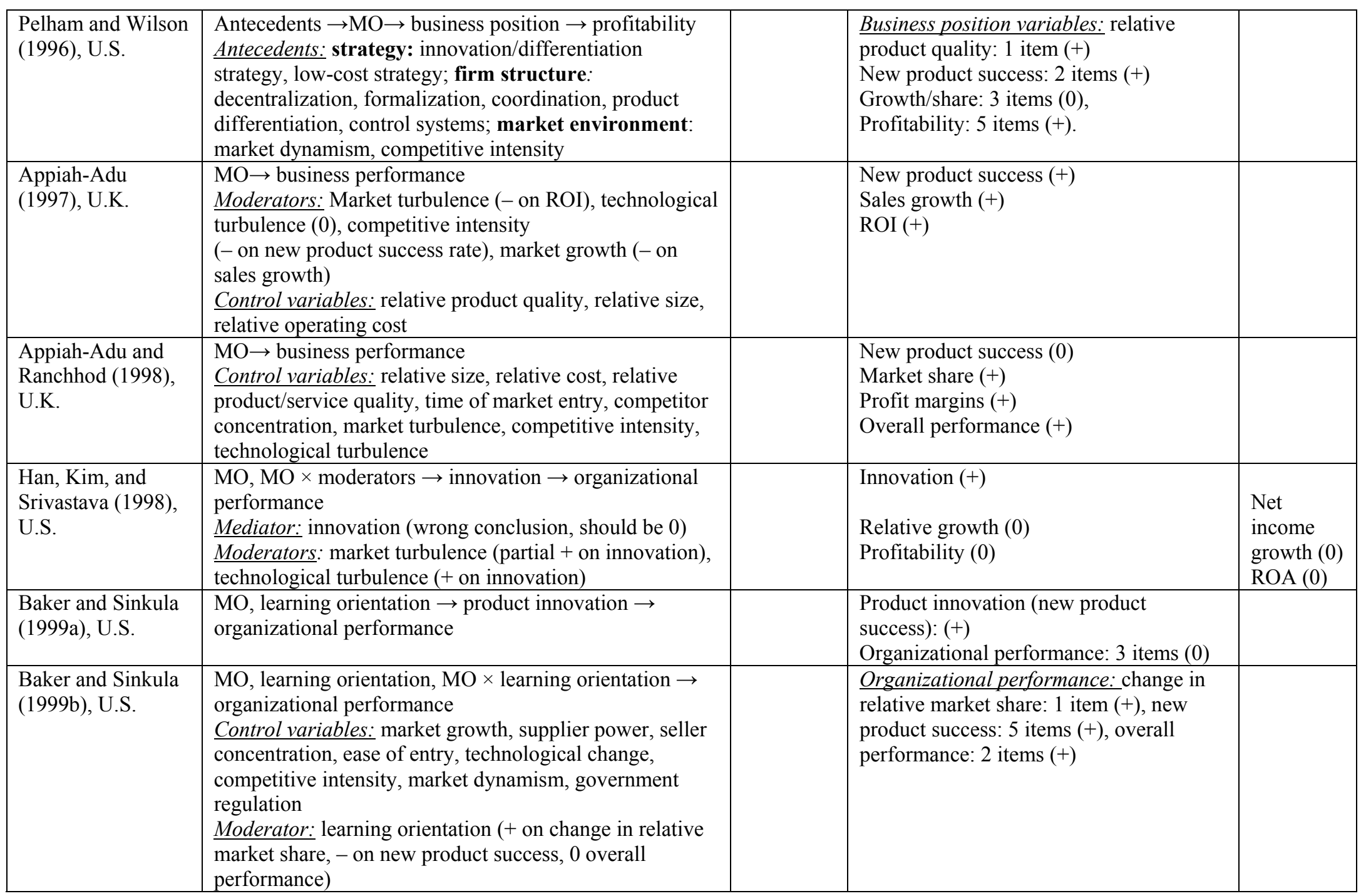




\begin{tabular}{|c|c|c|c|}
\hline $\begin{array}{l}\text { Lukas and } \\
\text { Ferrell (2000), } \\
\text { U.S. }\end{array}$ & $\mathrm{MO} \rightarrow$ product innovation & $\begin{array}{l}\text { Product innovation: Line extensions ( } 0 \text { on } \\
\text { customer orientation, }- \text { on competitor } \\
\text { orientation, }+ \text { on interfunctional coordination) } \\
\text { me-too product ( }- \text { on customer orientation, }+ \text { on } \\
\text { competitor orientation, }- \text { on interfunctional } \\
\text { coordination), new-to-the-world products } \\
\text { ( }+ \text { on customer orientation, }- \text { on competitor } \\
\text { orientation, } 0 \text { on interfunctional coordination). }\end{array}$ & \\
\hline $\begin{array}{l}\text { Matsuno and } \\
\text { Mentzer } \\
(2000), \text { U.S. }\end{array}$ & $\begin{array}{l}\text { MO, } \mathrm{MO} \times \text { moderators } \rightarrow \text { business } \\
\text { performance } \\
\text { Moderator: business strategy type } \\
(+): \text { prospectors, analyzers, } \\
\text { reactors }\end{array}$ & $\begin{array}{l}\text { Business performance: } \text { market share growth, } \\
\text { relative sales growth, new product sales as a } \\
\text { percentage of total sales, ROI }\end{array}$ & \\
\hline $\begin{array}{l}\text { Hult and } \\
\text { Ketchen } \\
(2001), \text { U.S. }\end{array}$ & $\begin{array}{l}\text { MO, entrepreneurship, } \\
\text { innovativeness, organizational } \\
\text { learning } \rightarrow \text { positional advantage } \\
\rightarrow \text { performance }\end{array}$ & & $\begin{array}{l}\text { 5-year average } \\
\text { change in ROI } \\
(+), 5 \text {-year } \\
\text { percentage } \\
\text { change in } \\
\text { income }(+), 5 \text { - } \\
\text { year percentage } \\
\text { change in stock } \\
(+)\end{array}$ \\
\hline $\begin{array}{l}\text { Kahn (2001), } \\
\text { U.S. }\end{array}$ & $\begin{array}{l}\text { MO, interdepartmental integration } \\
\rightarrow \text { performance }\end{array}$ & $\begin{array}{l}\text { Product development performance (+ marketing } \\
\text { managers; } 0 \text { for manufacturing and R\&D } \\
\text { managers) } \\
\text { Product management performance (+ for } \\
\text { marketing and manufacturing managers, } 0 \text { for } \\
\text { R\&D managers) }\end{array}$ & \\
\hline $\begin{array}{l}\text { Langerak } \\
(2001) \text {, the } \\
\text { Netherlands }\end{array}$ & $\begin{array}{l}\text { Self-reports downstream MO, } \\
\text { customer reports downstream MO, } \\
\text { self-reports upstream MO, supplier } \\
\text { upstream } \mathrm{MO} \rightarrow \text { self-reports } \\
\text { business performance } \\
\text { Control variables: } 27 \text { items }\end{array}$ & $\begin{array}{l}\text { Sales growth }(+) \text {, profit }(+), \text { NPD success }(+) \text {, } \\
\text { ROI }(+)\end{array}$ & \\
\hline
\end{tabular}




\begin{tabular}{|c|c|c|c|}
\hline $\begin{array}{l}\text { Raju and Lonial } \\
\text { (2001), U.S. }\end{array}$ & Quality context $\rightarrow \mathrm{MO} \rightarrow$ performance & $\begin{array}{l}\text { Performance }(+) \text { : Financial performance: } \\
\text { new profits, ROI, cash flow from } \\
\text { operations, ROA, profit-to revenue ratio; } \\
\text { Market/product development: new } \\
\text { product/service development, investments } \\
\text { in R\&D aimed at new innovation, capacity } \\
\text { to develop a unique competitive profile, } \\
\text { market development; quality outcomes: } \\
\text { mortality and morbidity rate, service quality } \\
\text { as perceived by customers, cost per adjusted } \\
\text { discharge, employee turnover }\end{array}$ & \\
\hline $\begin{array}{l}\text { Matear et al. } \\
\text { (2002), New } \\
\text { Zealand }\end{array}$ & $\begin{array}{l}\mathrm{MO} \rightarrow \text { innovation } \rightarrow \text { performance } \\
\text { Or: } \mathrm{MO} \times \text { innovation }(0) \rightarrow \text { performance }\end{array}$ & $\begin{array}{l}\text { Innovation: }(+) \\
\text { Performance: } 2 \text { items: financial } \\
\text { performance }(+), \text { market performance }(+)\end{array}$ & \\
\hline $\begin{array}{l}\text { Matsuno, } \\
\text { Mentzer, and } \\
\text { Ozomer (2002), } \\
\text { U.S. }\end{array}$ & $\begin{array}{l}\text { Entrepreneurial proclivity } \rightarrow \\
\text { organizational structure } \rightarrow \mathrm{MO} \rightarrow \\
\text { business performance } \\
\text { Antecedents: entrepreneurial proclivity } \\
\end{array}$ & $\begin{array}{l}\text { Market share }(+) \text {, percentage of new } \\
\text { product sales to total sales }(+), \text { ROI }(+)\end{array}$ & \\
\hline $\begin{array}{l}\text { Noble, Sinha, } \\
\text { and Kumar } \\
\text { (2002), U.S. }\end{array}$ & $\begin{array}{l}\text { MO, strategic orientation } \rightarrow \\
\text { organizational learning, innovativeness } \\
\rightarrow \text { firm performance } \\
\text { Mediators: organizational learning, } \\
\text { innovativeness }\end{array}$ & & $\begin{array}{l}\text { ROA (+ only for } \\
\text { competitor } \\
\text { orientation } \\
\text { dimension), ROS } \\
\text { (+only for } \\
\text { competitor } \\
\text { orientation } \\
\text { dimension) }\end{array}$ \\
\hline $\begin{array}{l}\text { Agarwal, } \\
\text { Erramilli, and } \\
\text { Dev (2003), U.S. }\end{array}$ & $\begin{array}{l}\text { MO } \rightarrow \text { innovation } \rightarrow \text { judgmental } \\
\text { performance } \\
\rightarrow \text { objective performance } \\
\text { Mediator: innovation, judgmental } \\
\text { performance }\end{array}$ & $\begin{array}{l}\text { Innovation: }(+) \\
\text { Judgmental performance }(+) \text { : service } \\
\text { quality, customer satisfaction, employee } \\
\text { satisfaction }\end{array}$ & $\begin{array}{l}\frac{\text { Objective }}{\text { performance }(0} \\
\text { direct, }+ \\
\text { indirect) } \\
\text { occupancy rate, } \\
\text { gross operating } \\
\text { profit, market } \\
\text { share }\end{array}$ \\
\hline
\end{tabular}




\begin{tabular}{|c|c|c|c|}
\hline $\begin{array}{l}\text { Im and } \\
\text { Workman } \\
\text { (2004), U.S. }\end{array}$ & $\begin{array}{l}\mathrm{MO} \rightarrow \mathrm{NP} \text { and MP creativity } \rightarrow \mathrm{NPP} \\
\text { Mediator: NP and MP creativity }\end{array}$ & $\begin{array}{l}\text { New product creativity }(+) \text { : novelty and } \\
\text { meaningfulness; Marketing program } \\
\text { creativity }(+) \text { : novelty and meaningfulness; } \\
\text { NPP }(0) \text { : market, financial, and overall } \\
\text { assessment measures }\end{array}$ & \\
\hline $\begin{array}{l}\text { Langerak, } \\
\text { Hultink, and } \\
\text { Robben (2004), } \\
\text { the Netherlands }\end{array}$ & $\begin{array}{l}\mathrm{MO} \rightarrow \text { product advantage, market testing, } \\
\text { launch budgeting, launch strategy, launch } \\
\text { tactics } \rightarrow \mathrm{NPP} \rightarrow \text { firm performance }\end{array}$ & $\begin{array}{l}\text { A second-order scale with five subscales: } \\
\text { market level, financial, customer } \\
\text { acceptance, product level, timing measures } \\
\text { of NPD success. }\end{array}$ & \\
\hline Wei (2004) & $\begin{array}{l}\mathrm{MO}, \mathrm{MO} \times \text { moderators } \rightarrow \mathrm{NPP} \rightarrow \text { firm } \\
\text { performance } \\
\text { Moderators: compensation strategies: } \\
\text { group-based pay vs. individual-based pay, } \\
\text { risk-based pay vs. risk-aversion pay, } \\
\text { long-term based pay vs. short-term based } \\
\text { pay }\end{array}$ & $\begin{array}{l}N P P(+): 3 \text { items: sales growth of new } \\
\text { products, management satisfaction with new } \\
\text { product performance, management } \\
\text { satisfaction with new product performance }\end{array}$ & $\begin{array}{l}\frac{N P P}{(+) P e r c e n t a g e ~ o f ~} \\
(1) \text { sales (2) sales } \\
\text { growth, of new } \\
\text { product } \\
\text { introduced /size } \\
\text { of NPD } \\
\text { department; } \\
\text { Firm } \\
\text { performance: } \\
\text { market } \\
\text { share/firm size in } \\
\text { this 2 years }\end{array}$ \\
\hline $\begin{array}{l}\text { Zhou, Yim and } \\
\text { Tse (2005): } \\
\text { China }\end{array}$ & $\begin{array}{l}\text { MO, technology orientation, } \mathrm{EO}) \rightarrow \\
\text { technology-based innovation, market- } \\
\text { based innovation } \rightarrow \text { firm performance, } \\
\text { product performance } \\
\text { Mediator: technology-based innovation, } \\
\text { market-based innovation }\end{array}$ & $\begin{array}{l}\text { Technology-based innovation }(+) \text {, market- } \\
\text { based innovation }(-) \text {, innovations on firm } \\
\text { performance }(+) \text {, innovations on product } \\
\text { performance }(+)\end{array}$ & \\
\hline
\end{tabular}


have demonstrated that MO significantly affects new product success (e.g., Appiah-Adu 1997; Atuahene-Gima 1995; Baker and Sinkula 1999a, b; Cooper 1994; Pelham 1997b; Slater and Narver 1994). However, other studies do not support this relationship (e.g., Appiah-Adu and Ranchhod 1998; Atuahene-Gima 1996; Greenley 1995). In the following section, I review the most influential studies that focus on only the relationship between MO and new product innovation.

Atuahene-Gima $(1995,1996)$ studies the MO-NPP and MO-innovation relationships. The 1995 study examines the direct effect of MO on new product activities and performance as well as the moderating effects of the degree of product newness, the intensity of market competition and the hostility of the industry environment, and the stage of the product life cycle on the MO-NPP relationship. The results show that MO is positively related to NPP in terms of market performance, proficiency of product development and launch activities, service quality, product advantage, marketing synergy, and teamwork. Atuahene-Gima also finds significant moderating effects. Market orientation has a stronger effect on the new product if the change is incremental rather than radical. Market orientation also has a greater effect when the intensity of market competition and the hostility of the industry environment are perceived as high and during the early stage of the product life cycle.

Atuahene-Gima (1996) also investigates the influence of MO on innovation characteristics and performance. The findings suggest that $\mathrm{MO}$ is significantly related to innovation characteristics such as the fit of innovation and marketing, product advantage, and interfunctional teamwork but not with product newness and fit between innovation and technology. After controlling for the effect of innovation characteristics, MO still makes 
strong contributions to the project impact performance but not to the market success of product inovation in terms of sales and profit performance.

Han, Kim, and Srivastava (1998) suggest an MO-innovation-performance

framework. They use a component-wise approach and test how the three core components of MO (customer orientation, competitor orientation, and interfunctional coordination) affect organizational innovativeness. They do not measure organizational innovation by NPD performance but from an organizational-content perspective that includes technical and administrative innovation. Their findings suggest that $\mathrm{MO}$ does not directly lead to superior firm performance, but it does directly lead to innovation, which is in turn related to performance. Therefore, innovation plays a mediating role in the relationship between MO and performance.

Lukas and Ferrell's (2000) study is one of the few studies that links MO to radical and incremental product innovation. Using a sample of U.S. manufacturing companies, their analysis shows that product innovation varies with MO. Customer orientation increases the introduction of new-to-the-world products and reduces the launching of me-too products. Competitor orientation increases the introduction of me-too products and reduces the launching of line extensions and new-to-the-world products. Interfunctional coordination increases the launching of line extensions and reduces the introduction of me-too products.

Langerak, Hultink, and Robben (2004) investigate the structural relationships among MO, new product advantage, proficiency in new product launch activities, NPP, and organizational performance. Their findings indicate that $\mathrm{MO}$ is positively related to product advantage and to the proficiency in market testing, launch budgeting, launch strategy, and launch tactics. Product advantage and the proficiency in launch tactics play pure mediator 
roles in the relationships among MO and NPP and organizational performance. Therefore, MO has no direct effect on NPP or organizational performance.

Im and Workman (2004) examine the mediating role of new product and market program creativity in the relationship between $\mathrm{MO}$ and new product success. They use a twostage sampling frame to collect 312 sets of responses in order to reduce common-method bias in measures of creativity and NPP. They measure creativity from meaningfulness and novelty perspectives. The results support the MO-new product/market program creativity-NP success model.

In summary, when scholars have studied the relationship between MO and NPP, they have used different measurements to measure new product innovation, and they have sometimes found MO to have a positive impact on new product innovation. Except for using different measurements for new product innovation, is there any other reason that MO sometimes affects new product innovation and sometimes not? It is very important to both practitioners and researchers to investigate the answer to this question. This dissertation attempts to search for this answer from the organizational learning perspective. How information-processing capabilities affect invention and innovation is listed by Bell, Whitwell, and Lukas (2002) as a top future research topic in NPD literature. Market orientation represents a firm's capability in marketing information processing and is valuable because it emphasizes not only continuously collecting customers' and competitors' information but also using this information to create continuous superior customer value (Slater and Narver 1995). Jaworski and Kohli (1993) define MO from marketing information-processing and organizational learning perspectives. Market orientation consists of information acquisition, intelligence dissemination, and organizational responsiveness, 
which are also the key elements for organizational learning (Sinkula 1994). Therefore, a market-oriented organization is a learning organization (Slater and Narver 1995). This dissertation examines the MO-new product innovation relationship through the lens of organizational learning. In the following section, I review the literature of learning theory.

\subsection{Organizational Learning Theory}

Organizational learning is a very important topic for both literature and practice. Organizational learning may lead to behavior change and improved organizational performance by enhancing action-oriented use, knowledge-enhancing use, and affective use (Slater and Narver 1995). Although there is a large and growing body of literature on organizational learning, there remains a lack of consensus across disciplines on what organizational learning is (Bell, Whitewell, and Lukas 2002; Crossan, Lane, and White 1999).

Many different definitions of organizational learning exist in the literature. Cyert and March (1963) define organizational learning as the process by which organizations as collectives learn through interaction with their environments. Similarly, Slater and Narver (1995) define organizational learning as the development of new knowledge or insights that have the potential to influence behavior. Furthermore, Cohen and Levinthal (1990) define organizational learning as the process of assimilating new knowledge into the organization's knowledge base. Organizational learning begins at the individual level. New individual knowledge is transferred to the organization's knowledge base only when it is shared and assimilated into routines, documents, and practices (Autio, Sapienza, and Almeida 2000). 
In the following section, I review the literature about different theories of organizational learning.

\subsubsection{Organizational Learning Theories}

Hitt, Ireland, and Hoskisson (1999) argue that firms in the "new competitive landscape" need the ability to adapt to environmental change with innovation and speed. Contingency theorists have maintained that firms in uncertain environments should develop flexible processes to react successfully to adversity or unexpected change (Galbraith 1977). Therefore, I briefly review the environmental uncertainty literature before examining different organizational learning theories.

\subsubsection{Environmental Uncertainty}

There are many types of environmental characteristics that have been examined in the strategic marketing and management literature, such as environmental uncertainty, complexity, hostility, market potential, and intensity of competition (Frese, Brantjes, and Hoorn 2002). Uncertainty (or dynamism) is the degree to which an environment is predictable or unpredictable. Complexity is the intricacy and qualitative nature of the environment. Hostility is pressure from competitors, if there is a negative business climate and a relative lack of exploitable opportunities (Covin and Slevin 1989). Market potential pertains to the attractiveness of a target market or the need level of customers, which reflects market characteristics such as size and growth (Song and Parry 1997). Competitive intensity refers to the nature of interfirm rivalry within the firm's target market (Song and Parry 1997). Among these characteristics, environmental uncertainty may be the most important because a firm's actions are affected significantly by decision makers' perceptions of environmental 
uncertainty (Ireland, Hitt, Bettis, and Porras 1987). It is difficult to make accurate predictions about the future in a highly uncertain environment (Achrol and Stern 1988; Celly and Frazier 1996).

Many researchers have suggested that environmental uncertainty is a crucial contingency for organizations (Hambrick 1981; Ireland et al. 1987), where uncertainty is the unpredictability of environmental variables that have an impact on organizational performance (Miller 1993). There are three types of perceived uncertainty about the environment: (1) state, (2) effect, and (3) response (Milliken 1987). State uncertainty refers to the general unpredictability of the environment and its various components. Effect uncertainty is the inability of firms to predict the effect of future environmental changes on business operations. Response uncertainty captures the difficulty that firms have in predicting the response of their competitors to a particular strategy that the firm implemented.

Uncertainty can be conceived of on three levels: (1) general environmental, (2) industry, and (3) firm-specific variables. General environmental uncertainties include political and governmental policy instability and macroeconomic uncertainty. Industry uncertainties encompass input market, product market, competitive, and technological uncertainties. Firm-specific uncertainties include uncertainties regarding operation, R\&D, and management and employee actions. International management research highlights the general environmental uncertainties, but strategy studies have tended to focus on industryand firm-level uncertainties (Miller 1993).

In the marketing literature, the most commonly cited types of environmental uncertainties are technology uncertainty and demand uncertainty (Anderson and Tushman 2001; Atuahene-Gima and Li 2004; Jaworski and Kohli 1993). Technology uncertainty (also 
called technology turbulence) concerns the perceived rate of technological change. Demand uncertainty (also called market turbulence) is the perceived rate of change and the unpredictability of customers' product preferences, customer demand, and competitors' behavior in response to the change. The literature suggests that in highly uncertain situations, decision makers are unable to assess accurately both the present and the future state of the environment. Objective characteristics or information are often not available to provide a basis for action. Information changes so fast that decision makers have to continuously update their information. Decision makers must use personal judgment and take risks to make quick decisions at each critical point (Atuahene-Gima and Li 2004; Jaworski and Kohli 1993; Milliken 1987). Decision-maker scanning frequency and scanning interest therefore increase when perceived environmental uncertainty increases (Sawyerr 1993). Therefore, heavy and intense organizational learning is a requirement for organizations to survive by successful adaptation to a highly uncertain environment.

\subsubsection{Different Perspectives on Organizational Learning}

Organizational learning is conceptualized from many different perspectives, including cognitive, strategic renewal, information process, and social network perspectives.

From a cognitive perspective, the two types of organizational learning are adaptive and generative (Senge 1990; Slater and Narver 1995). Adaptive learning occurs within a set of both recognized and unrecognized constraints that reflect the organization's assumptions about its environment and itself. The learning boundary constrains organizational learning to adaptive learning, which usually is sequential, incremental, and focused on issues or opportunities that are within the traditional scope of the organization's activities. Generative 
learning occurs when the organization is willing to question long-held assumptions about its mission, customers, capabilities, or strategy. It requires the development of a new way of looking at the world based on an understanding of the systems and relationships that link key issues and events (Senge 1990; Slater and Narver 1995).

Adaptive and generative learning are also referred to, respectively, as low- and highlevel learning, first- and second-order learning, and single- and double-loop learning (Argyris 1999; Arthur and Aiman-Smith 2001; Foil and Lyles 1985; Slater and Narver 1995). In this dissertation, I use the terms single- and double-loop learning. Single-loop learning is a routine, incremental, conservative process that serves to maintain stable relations and sustain existing rules (Argyris 1999; Arthur and Aiman-Smith 2001; Foil and Lyles 1985). Its outcome is expected to be incremental change or adaptation carried out to further exploit existing technologies, routines, and processes in a way that does not alter underlying assumptions or values. Therefore, single-loop learning restricts itself to detect and correct errors within a given systems of rules (Argyris 1999; Arthur and Aiman-Smith 2001; Foil and Lyles 1985).

Double-loop learning is the search for and exploration of alternative routines, rules, technologies, goals, and purposes (Argyris 1999; Arthur and Aiman-Smith 2001; Foil and Lyles 1985). This type of learning resolves incompatible organizational norms by setting new priorities and weighting of norms or by restructuring norms themselves, together with associated strategies and assumptions. Double-loop learning enables organizations to break out of existing thought or behavior patterns by exploring qualitatively different ways of thinking and doing things (Argyris 1999; Arthur and Aiman-Smith 2001; Foil and Lyles 1985). From a strategic renewal perspective, Crossan, Lane, and White (1999) develop a 
comprehensive framework of the process of organizational learning and identify

organizational learning as comprising four processes-(1) intuition, (2) interpretation, (3) integration, and (4) institutionalization—at the individual, group, and organizational levels.

This study suggests four key assumptions or premises for organizational learning. First, organizational learning involves a tension between assimilating new learning (exploration) and using what has been learned (exploitation). Second, organizational learning involves multiple levels: individual, group, and organization. Third, three levels of organizational learning can be linked by the social and psychological processes of intuiting, interpreting, integrating, and institutionalizing (4Is). Fourth, cognition affects action, and vice versa. The 4I framework of organizational learning maps the process within the organizations.

Intuition. Intuition is the preconscious recognition of the pattern and/or possibilities inherent in the personal stream of experience. The expert view of intuiting is a process of past pattern recognition. The ability to make novel connections and to discern possibilities is the key for intuiting. Whereas expert intuition may be past pattern-oriented, entrepreneurial intuition is future possibility-oriented. Expert intuition supports exploitation, whereas entrepreneurial intuition supports exploration.

Interpretation. Interpretation is the explanation, through words and/or actions, of an insight or idea to oneself and to others. Interpreting takes place in relation to a domain or an environment. Individuals interpret the same stimulus differently because of their established cognitive maps. High-quality information may be equivocal with multiple and conflicting meanings. A group interpretive process may resolve equivocal situations. 
Integration. Integration is the process of developing shared understanding among individuals and of taking coordinated action through mutual adjustment. Shared understanding is crucially developed from dialogue and joint action. Whereas the focus of interpreting is change in the individual's understanding and actions, the focus of integrating is coherent, collective action. Shared understanding comes from the continuing conversation among members of the community. Shared practice may lead to the development of collective mind and mutual adjustment or negotiated action.

Institutionalization. Institutionalization is the process of embedding individual and group learning into the organization, and it includes systems, structures, procedures, and strategy. The process of institutionalizing sets organizational learning apart from individual or ad-hoc group learning. Some learning is embedded in the systems, structures, strategy, routines, prescribed practices of the organization, and investments in information systems and infrastructure. For new or young organizations with few established routines or structures, individual and group learning is dominant. As organizations mature, individuals begin to fall into patterns of interaction and communication, and the organizations attempt to capture the patterns of interaction by formalizing them. Structures, systems, and procedures provide a context for interactions. It takes time to transfer learning form individuals to groups and from groups to the organization. As the environment changes, the learning that has been institutionalized may no longer fit the context.

These 4I processes are related in feed-forward and feedback processes across the levels. Learning not only occurs over time and across levels but also creates tension between assimilating new learning (feed-forward) and exploiting or using what has already been learned (feedback). In feed-forward processes, new ideas and actions flow from the 
individual to the group and to the organization level. At the same time, what has already been learned feeds back from the organization to group and individual levels, thus affecting how people act and think. The institutionalized learning, or what has already been learned, may impede the assimilation of new learning. Therefore, the nature of the learning process itself may create tension between the feed-forward and feedback, which is also referred to as tension between exploration and exploitation.

Several problems may occur in the learning-flow process (Crossan, Lane, and White 1999). First, there may be bottlenecks in the ability of the organization to absorb the feedforward of learning from the individual to the group and organization. Investment in individual learning and pressures for new product innovation may become stockpiled if the organization has limited capacity to absorb the learning. Individuals may become frustrated and disenchanted and may even leave the organization. Second, learning that has become institutionalized at the organizational level is often difficult to change, because it runs the risk of becoming irrelevant and may even obstruct feed-forward learning flows. In addition, inertia and rigidity may block the learning process.

Many factors could facilitate or inhibit the tension between feed-forward (exploration) and feedback (exploitation), such as reward systems, information systems, resource allocation systems, strategic planning systems, and structure. Exploration of these factors is one promising area for future research in organization learning. This dissertation studies when the new product learning process may lead to learning inertia and how to solve it.

From an information-processing perspective, Huber (1991) and Sinkula (1994) suggest that organizational learning has four processes: (1) knowledge acquisition, (2) 
information distribution, (3) information interpretation, and (4) organizational memory. Knowledge acquisition is the process by which knowledge is obtained. Information distribution is the process by which information from different sources is shared, and it thereby leads to new information or understanding. Information interpretation is the process by which distributed information has one or more commonly understood interpretation. Organizational memory concerns how organizations encode, store, and retrieve the lessons of history, despite the turnover of personnel and the passage of time. More specifically, knowledge acquisition consists of (1) drawing on knowledge available at the organization's birth, (2) learning form experience, (3) learning by observing other organizations, (4) grafting on to itself components that possess knowledge needed but not possessed by the organization, and (5) noticing or searching for information about the organization's environment and performance.

The attributes of organizational learning can be categorized by existence, breadth, elaborateness, and thoroughness (Huber 1991). Existence means that an organizational learner is recognized as potentially useful to the organization if any of its units acquire knowledge. Breadth refers to the situation in which more organizational learning occurs when more of the organization's components obtain the knowledge and recognize it as potentially useful. Elaborateness refers to a situation in which organizational learning occurs when more and more varied interpretations are developed. Thoroughness of organizational learning occurs when more organizational units develop uniform comprehension of the various interpretations. 
Slightly different from Sinkula's (1994) version, Slater and Narver (1995) reduce the processes of organizational learning from four to three: (1) information acquisition, (2) information dissemination, and (3) shared interpretation.

Information acquisition. Information may be acquired from direct experience, the experiences of others, or organizational memory. Organizations must continuously balance learning with exploitation (internally focused experience) and exploration (externally focused experience). In addition, learning from others encompasses benchmarking, joint ventures, networking, strategic alliances, and working with lead customers.

Information dissemination. Effective dissemination increases information value when each piece of information can be seen in its broader context by all organizational players who might use or be affected by it and who are able to feed back questions, amplification, or modifications that provide new insights to the sender.

Shared interpretation. For organizational learning to occur in any business unit, there must be a consensus on the meaning of the information and its implications for that business. However, high performance in a dynamic environment requires balancing the need for rapid decision making with the need to carefully consider the ramifications of alternative action plans through effective conflict resolution processes.

From a social network perspective, organizational learning is viewed as the organizational connections that constitute a learning network rather than as information transfer from one individual mind to another (Fisher and White 2000). It is a reflective process and is played out by members at all levels in the organization. It involves the collection of information from both external and internal environments. This information is filtered through a collective sense-making process, which results in shared interpretations 
that can be used to instigate actions that result in enduring changes to the organization's behavior and theories-in-use.

When organizational learning is perceived as an aggregate of individual information processes, individual memories represent essential pieces of the organizational memory. Therefore, the loss of a significant individual memory "chunk" can create a hole in organizational memory that damages ongoing processes.

In contrast, a social network frame assumes that learning is generated at the intersubjective level. From the social network perspective, learning is situated within an interactive context, rather than in either the minds of individuals or the organization. Therefore, learning is subject to system interaction effects that are located not in individual learning entities or nodes but in the connections between nodes. Social network thinking fits the definition of organizational learning with its focus on shared interpretation.

Having synthesized major existing organizational theories in the literature, I review in the following section how the literature applies these theories in different research domains.

\subsubsection{Network Perspective on Organizational Learning}

From the social network perspective, Fisher and White (2000) view organizational learning as the organizational connections that constitute a learning network rather than as information transfer from one individual mind to another. Learning is situated within an interactive context, rather than in either the minds of individuals or the organization as a whole. Therefore, system interaction effects are not located in individual learning entities or nodes but in the connections between nodes. 
According to the network perspective, most firms are embedded in multiple networks that include sister subsidiaries, parent companies, competitors, investors, government institutions, suppliers and distributors, and regulatory bodies (Dyer and Singh 1998; Young, Charns, and Shortell 2001). According to Gulati, Nohria, and Zaheer (2000), firms are embedded in networks of social, professional, and exchange relationships with other firms. The networks' relationships can be horizontal and vertical, including those across industries and countries. Slater and Narver (1995) argue that the learning organization's architecture should be open to external "learning partners." It is very important for organizations to learn from customers, distributors, suppliers, alliance partners, universities, and others (Slater and Narver 1995). Managers may limit the value of the exchange when they treat those information exchanges as independent transactions (Slater and Narver 1995). Conversely, the development of long-term, stable relationships with "learning partners" leads to information sharing, which benefits both partners (Slater and Narver 1995). Therefore, organizational learning is a function of the form and strength of the organization's interdependence with its learning partners (Webster 1992).

The literature includes several studies that examine how organizations can benefit from their networks. First, strategic networks can potentially provide a firm with access to information, resources, markets, and technologies, as well as advantages from learning, scale, and scope economies (Gulati, Nohria, and Zaheer 2000). According to Liebeskind, Oliver, Zucker, and Brewer (1996), an external informational network of experts can provide the firm with multiple evaluations of the value of its own information and know-how. Networks can increase the firm's efficiency in searching for valuable information, screening information, codifying information for managerial use, selecting appropriate investments, 
and applying managerial control. Therefore, sourcing information from external experts increases organizational learning (Liebeskind et al. 1996).

Second, interorganizational relationships in a network are positively related to knowledge acquisition and explication. The study of Yli-Renko, Autio, and Sapienza (2001) shows that social interaction and network ties are indeed associated with greater knowledge acquisition. Interorganizational relationships create opportunities for knowledge acquisition and exploitation. Through interaction with others, firms get access to extent knowledge and can combine it with existing knowledge. They then can apply and exploit newly created knowledge through such relationships. Cohen and Levinthal (1990) argue that the ability to exploit external knowledge is a critical component of innovative capabilities. Network learning can enhance the firm's ability to acquire and use outside knowledge because networks provide a diversity of knowledge in the innovation process. Organizational learning is therefore a function of both access to knowledge and the capabilities for using and building on such knowledge.

Liebeskind and colleagues (1996) examine how two highly successful new biotechnology firms (NBFs) source their most critical input—scientific knowledge — through three organizational options: (1) internal sourcing through the use of hierarchy, (2) external sourcing through market exchange, and (3) external sourcing through social networks. They posit that social networks are the most efficient organizational arrangement for sourcing information because information is difficult to price in a market and difficult to communicate through a hierarchical structure. Social networks serve as a source of reliable information, which is essential to efficient organizational learning. Therefore, collaboration enhances organizational learning (Hamel 1991). They find that scientists at the two NBFs enter large 
numbers of collaborative research efforts with scientists at other organizations, especially universities. Formal market contracts are rarely used to govern these exchanges of scientific knowledge. Therefore, the use of boundary-spanning social networks increases both their learning and their flexibility in ways that would not be possible with a self-contained hierarchical organization.

Third, a network serves as a locus of innovation, because it provides timely access to knowledge and resources that are otherwise unavailable while also testing internal expertise and learning capabilities. Networks also facilitate learning by promoting efficient skill transfer among firms or by producing novel syntheses of existing information. Furthermore, good knowledge transfer among organizational units provides opportunities for mutual learning that stimulate the creation of new knowledge and foster innovation (Tsai 2001).

Powell, Koput, and Smith-Doerr (1996) also conduct a study of the network learning in biotechnology firms. In the past, firms organized R\&D internally and relied on outside contract research only for relatively simple functions or products. Now a large-scale reliance on interorganizational collaborations in the biotechnology industry exists in order to access the knowledge. The authors argue that, when the knowledge base of an industry is both complex and expanding and the sources of expertise are widely dispersed, the locus of innovation is found in learning networks rather than in individual firms. Sources of innovation do not reside exclusively inside firms. It is more likely that they are commonly found in the interstices among firms, universities, research laboratories, suppliers, and customers. New technologies are both a stimulus to and the focus of various cooperative efforts to reduce the inherent uncertainties associated with novel products or markets. 
Fourth, uncertainty can be reduced through networking. Firms benefit from organizational networks with strong ties by mitigating uncertainty and promoting adaptation because communication and information sharing increase (Kraatz 1998). They also enable firms to achieve strategic objectives, such as sharing risks and outsourcing value-chain stages and organizational functions. Therefore, the networks of relationships profoundly influence the firms' conduct and performance, including organizational survival amid competition and change (Gulati, Nohria, and Zaheer 2000).

Networks are therefore considered potential sources of learning (Levitt and March 1988; Powell 1990). The experiences to which a firm is exposed through its associations with its network partners affect its decisions. In general, networks enable forums for discussion, direct attention to new practices, and facilitate the transmission of information and normative pressures to engage in certain activities (Beckman and Haunschild 2002). However, it is not enough for firms to have networks. The quality of networks matters to the network learning. Depending on the variety of information available, some network structures may be better than others at helping firms make better decisions. Three features of network structure are important for decision quality: (1) network size, (2) network heterogeneity, and (3) strength of network.

The first feature of network structure is the network size or range. A network with a narrow learning scope may lead to more limited organizational learning capacity than one that has a broad learning scope. Reagans and McEvily (2003) study how different features of informal networks affect knowledge transfer. They argue that the network range, or ties to different knowledge pools, increases a person's ability to convey complex ideas to 
heterogeneous audiences. A large network is highly likely to lead to worldviews. The results indicate that both social cohesion and network range ease knowledge transfer.

The second feature of network structure is the network's heterogeneity. Network structure can affect decision quality because of the partners' heterogeneity. The theory of structural holes pertains to how the structure of learning networks affects the magnitude of learning loss (Burt 1992). Networks with relatively weak linkage density but with heterogeneous, rather than redundant, relationships are more efficient than dense networks in which every member shares similar links with all other members. Network partners' heterogeneity provides firms with more diverse samples of experience from which to learn.

Beckman and Haunschild (2002) examine the effect of the diversity of network partners' experience on a firm's acquisition decisions. Results show that firms with multiplex relationships with partners receive more benefit; that is, collective network experience affects firms' decision quality. Diversity among network partners may create informational diversity. Therefore, firms with diverse partner experiences are likely to debate and deliberate these experiences more than firms with homogeneous network experience. The process through which network diversity can result in improved decisions has multiple steps. First, the diverse experiences of network partners provide firms with a variety of instrumental, normative, and procedural information. Second, the diverse experiences of network partners increase organizational attention to existing information.

The third feature of network structure is the strength of the network, which is also referred to as strong or weak network ties. Strong network ties are defined as frequent interaction, an extended history, and intimacy (Kraatz 1998). According to Rowley, Behrens, and Krackhardt (2000), strong ties have two advantages. First, strong ties are associated with 
the exchange of high-quality information and tacit knowledge. Based on a deeper understanding of a partner's operations, tacit knowledge is more readily transferred across organizational boundaries. Second, strong ties may serve as part of the social control mechanism, which governs partnership behaviors. Larson (1992) shows that strong ties incrementally promote and enhance trust, mutual gain, reciprocity, and a long-term perspective. However, weak ties can be beneficial because they provide access to divergent regions of the network rather than to a densely connected set of actors. Strong and weak ties have different qualities, which are advantageous for different purposes. A mix of strong and weak ties may be preferable for firms.

Several studies have made an effort to link together the concepts of network and organizational learning. Tsai (2001) studies how the firms conduct organizational learning through an intraorganizational network. According to the network perspective, organizational units can produce more innovations and enjoy better performance if they occupy a central network position that facilitates knowledge transfer across units. Knowledge transfer among organizational units provides opportunities for mutual learning that stimulate the creation of new knowledge and foster innovation.

Kraatz (1998) is interested in how networks can promote social learning of adaptive responses. The study uses data from 230 private colleges over 16 turbulent years to show that the college members of smaller, older, and more homogeneous intercollegiate consortia are more likely to undertake fundamental curriculum changes. The colleges tend to imitate similar consortium partners that were performing well and not larger and more prestigious partners. Therefore, strong ties to other organizations may mitigate uncertainty and promote adaptation by increasing communication and information sharing. 
Fisher and White (2000) use a social network framework to study the impact of downsizing on organizational learning and propose that the effects can be viewed as a nonlinear function of learning network size. There is an incorrect assumption that all possible subgroups retain valuable, unique learning capacity and that the loss of any individual completely disables learning in every subgroup that he or she belongs to. This assumption attributes organizational learning failure to the elimination of workers during downsizing. A social network perspective views downsizing from a different angle.

Burt's (1992) theory of structural holes offers more insight into how the structure of learning networks may affect the magnitude of learning loss. Burt proposes that networks with relatively weak linkage density but with heterogeneous, rather than redundant, relationships are more efficient than dense networks in which every member shares similar links with all other members. This logic suggests that removal of individuals in dense networks with many redundant linkages would not necessarily significantly affect organizational learning capacity.

However, Burt (1992) also suggests that some individuals may be more strategically linked than others within the organization. Those individuals whose relationships span structural holes and account for a unique link between otherwise unlinked clusters in a network can be critical to the learning function. Removal of an individual who accounts for such a strategic link among diverse clusters could disconnect the clusters from one another and inflict damage to the organizational learning capacity. In conclusion, the magnitude of the potential damage to organizational learning capacity that results from downsizing is a nonlinear function that results in a progressively greater percentage of capacity lost per 
individual as the size of the operative learning networks embedded in the organization increases.

In this dissertation, network learning is of interest. Network learning is defined as the willingness to build strong relationships with broad parties outside of the firms and the amount of insights obtained from the external entities in the firms' economic network. The potential learning sources include customers, competitors, suppliers, distributors, businesses in different industries, consultants, universities, government agencies, and other organizations or individuals that possess knowledge valuable to the business (Achrol 1991; Dickson 1992; Kanter 1989; Slater and Narver 1995; Webster 1992). The marketing literature suggests that such networks represent a new organizational form that may replace simple market-based transactions (Webster 1992). Because of diverse knowledge sources and network perspectives, it may help a firm break out of inertia in its existing marketplace. Thus, it is relevant and important in this dissertation to study network learning.

\subsubsection{Applications of Organizational Learning Theories}

Organizational learning theories are applied to many different areas, such as NPD, knowledge flow, strategic change, quality management, and international business management.

When organizational learning is applied to the NPD process, the information process or learning process becomes very complicated. Akgun, Lynn, and Reilly (2002) argue that NPD learning has multiple dimensions: information acquisition, information implementation, unlearning, thinking, improvisation, memory, history, intelligence, and sense-making. Information acquisition refers to a collection of primary and secondary information from a 
variety of sources, such as data gathered from customers; competitors; economic, financial, and social reports; consultants; new members; acquisition and mergers; and cross-functional teams. Information implementation is the application of market and technical information to influence related market strategy and technical actions, such as prelaunching, incorporating lessons learned into the product for full-scale launch, uncovering and correcting product problem areas with which customers were dissatisfied, and implementing new product strategy. Information dissemination is the process by which information from different sources is distributed and shared, such as memos, reports, formal courses and training, informal communication, dialogue, teleconferencing, and Internet and intranet. Unlearning is the process of reducing or eliminating preexisting knowledge or habits, such as changing the organizational beliefs, norms, values, procedures, behavioral routines, and physical artifacts. Thinking refers to the purposeful, reasoned, and goal-directed action that involves solving problems, formulating inferences, calculating likelihoods, and making decisions by decision making, problem solving, and judgment. Improvisation is planning and implementing any action simultaneously, such as continuous improvement, experimentation, and trial and error. Memory refers to stored information, such as detailed past decisions, results, past surprises, and the organization's responses and unwritten decisions from an organization's history of core competencies, culture, structure, beliefs, and psychological structure. Intelligence concerns the capability and ability to process, interpret, manipulate, and use information in the organization, such as the ability to gather information from outside of the organization (e.g., customers, vendors, suppliers, libraries, consultants), generate different market and technology scenarios, interpret environmental signals, and transfer customer needs to 
product-design specifications. Sense-making means giving meaning to data and information, such as information coding and summarizing.

Following the knowledge perspective, Schulz (2001) studies the relationship between the learning process and knowledge flow. Knowledge flow is defined as the aggregate volume of know-how and information transmitted per unit of time. Knowledge may flow in two ways: horizontal or vertical. Horizontal outflows carry knowledge from a subunit to peer subunits, which are units that report to the same supervising unit. Vertical outflows carry knowledge from a subunit to its supervising unit. There are three learning processes: (1) collecting new knowledge, (2) codifying knowledge, and (3) combining old knowledge. The findings support that collecting new knowledge intensifies vertical flows of knowledge, that codifying knowledge facilitates horizontal and vertical flows, and that combining old knowledge mainly affects horizontal flows. The uncertain relevance of new knowledge may generate push and pull forces that stimulate outflows of knowledge from the knowledge domain of subunits.

The strategic change literature has studied organizational change through a learning lens. Rajagopalan and Spreitzer (1996) consider strategic change an iterative process. Managers effect changes through a series of relatively small steps designed to probe the environment and the organization. These learning steps can result in major and minor changes to the content of a firm's strategy. Therefore, the managers can learn during ongoing strategic change and experience successful strategic changes through different learning processes.

Sitkin, Sutcliffe, and Schroeder (1994) try to apply learning theory to quality management by total quality learning (TQL) rather than by total quality management (TQM). 
By focusing on this exploration-oriented aspect of TQM, TQL emphasizes increasing an organization's ability to explore the unknown and to identify and pursue novel solutions. Total quality learning is involved in many management activities, such as capability enhancement; information collection, analysis, and dissemination; and incentives for implementation. This study suggests that when task, product/process, or organizational uncertainty is low, practices associated with the implementation of TQC will increase outcome effectiveness. When task, product/process, or organizational uncertainty is high, practices associated with TQL implementation will increase outcome effectiveness.

International business is an active zone for organizational learning. Internationalizing firms must engage in learning in order to apprehend, share, and assimilate new knowledge and to compete and grow in markets in which they have little or no previous experience (Autio, Sapienza, and Almeida 2000). Using event-history analysis and data on 1493 expansions of 25 large Dutch firms between 1996 and 1994, Barkerma and colleagues (1997) report that successful international joint ventures entail both learning to operate across national boundaries and learning to cooperate with the joint-venture partner.

Several studies have also examined organizational learning from slightly different perspectives, such as absorptive capacity, learning orientation, and learning organization. These studies may not be real applications of organizational learning, but they are very influential studies in the organizational learning literature.

Cohen and Levinthal (1990) use the term absorptive capacity to study the organizational learning process. Absorptive capacity is the ability to recognize the value of new information, assimilate it, and apply it to commercial ends. The ability to exploit external knowledge is a critical component of innovative capabilities. The increase of 
technological opportunity will increase the amount of available relevant, external technical knowledge and will elicit more R\&D in more-difficult learning environments. An organization's absorptive capacity depends on transfers of knowledge across and within subunits that may be quite removed from the original point of entry. Therefore, the structure of communication between the external environment and the organization, as well as among the subunits of the organization, and knowledge sharing versus knowledge diversity across individuals, affect the development of organizational absorptive capacity. The authors' findings suggest that R\&D intensity increases when learning becomes more difficult, because R\&D creates an ability to assimilate and exploit new knowledge.

Sinkula, Baker, and Noordewier (1997) suggest a framework for market-based organizational learning. Organizations that are competent at learning are referred to as learning organizations or learning oriented. They are skilled at creating, acquiring, and transferring knowledge and at modifying their behaviors to reflect new knowledge and insights. Learning organization or orientation is measured on four dimensions: (1) commitment to learning, (2) shared vision and/or purpose, (3) open-mindedness, and (4) marketing program dynamism.

Slater and Narver (1995) argue that MO provides strong norms for learning from customer and competitors. In order to create a learning organization, the firm must conduct double-loop learning by setting up entrepreneurship and appropriate organizational structures and processes.

In summary, the previous two sections reviewed the organizational learning literature and its application. In following section, I will look at the negative side of organizational 
learning theory and search for the potential interesting missing variables for the MO-new product innovation relationship.

\subsubsection{Organizational Inertia and Rigidity}

Although organizational learning may have many positive effects on behavior and performance, the aforementioned literature review suggests that organizational learning itself may also create dysfunctional behavior and negative effects (Crossan, Lane, and White 1999; Foil and Lyles 1985).

Some studies try to identify the potential barriers for organizational learning. Adams, Day, and Dougherty (1998) identify three organizational learning barriers: (1) avoidance of ambiguity, (2) compartmentalized thinking, and (3) inertia. These barriers persistently act in specific ways to inhibit organizational learning. Avoidance of ambiguity occurs in the process of acquiring market information. People typically focus on the less ambiguous in order to more easily understood technologies and business truisms. Compartmentalized thinking happens in the process of disseminating market information. The dissemination may be hindered because people focus on their own goals, which are often defined within their department's role instead of the overall project goals. Inertia acts as a barrier to the effective use of market information. People tend to proceed as they always have, maintaining the status quo, rather than adjusting actions to capitalize on market learning.

Brown and Starkey (2000) study how organizational identity may inhibit organizational learning from a psychodynamic perspective. There are many reasons why organizations fail to learn. Although the literature recognizes cognitive limitations, prior learning, political games, and certain cultural and structural features of organizations as 
barriers to learning, it ignores the role of psychodynamic factors in individual and organizational identity and the negative effects that such factors can have on learning. The authors argue that it is possible for organizations to engage in routine-based learning in ways that support their existing self-concepts. If this sort of organizational learning requires identity change, organizations may engage in ego defenses to maintain collective self-esteem and the continuity of existing identity. At an organizational level, defenses inhibit learning by influencing the external search for the information and the interpretation, use, storage, and internal recall of information.

Therefore, the literature provides a reason to believe that creating an inertia trap may be one of the barriers that blocks the organizational learning process and suggests that it is important to study inertia to understand how it affects learning. In the following paragraphs, I review a portion of the literature on inertia.

Inertia refers to a tendency not to move or act (Gresov, Haveman, and Oliva 1993). Tushman and Romanelli (1985) study inertia from an ecological perspective. As organizations grow or age, and as they pass long periods without fundamental change, they become more complex, and greater interdependence develops within and between their activity systems. Greater complexity and interdependence builds resistance to fundamental change. Therefore, the probability of organizational change in core systems declines with size and age.

Hannan and Freeman $(1984,1989)$ suggest four internal factors that contribute to the stability of organizational forms: (1) past investment, (2) information-processing constraints on decision-makers, (3) internal politics, and (4) organizational history and the set of normative agreements that it engenders. Three external factors also constrain change in form: 
(1) legal and fiscal barriers to entry and exit from markets, (2) external constraints on the availability of information, and (3) environmental-imposed legitimacy constraints. These constraints act on all four properties of organizational form: (1) stated goals, (2) forms of authority, (3) core technology, and (4) marketing strategy.

More specifically, structural inertia theory (Hannan and Freeman 1984) argues that organizational reliability and accountability require organizational structures that are reproducible or stable over time. Structural institutionalization and standardization therefore offers the advantage of reproducibility. However, these structures can also generate strong pressures against change, because the organization's members seek to maintain the status quo that protects their interests. Constraints on change in the core features of organizations are very strong. Inertia is relative to environmental change. Inertia in the organizational structure is high when the speed of reorganization (core feature change) is much lower than the rate at which environmental conditions change. However, changing core features is dangerous, because it is costly for organizations. Organizational change may greatly increase risks of the demise of the organization. Organizations that frequently try to reorganize may produce very little and have slight chances of survival (Hannan and Freeman 1984). Therefore, inertia may not be negative in some situations.

Contrary to inertia theory predictions, Kelly and Amburgey (1991) show empirical evidence that discontinuous environmental change was not associated with an increased probability of organizational change. In addition, organizational change was unrelated to an organization's chances of survival.

Miller and Chen (1994) study the sources and consequences of competitive inertia. They define competitive inertia as the level of activity that a firm exhibits when altering its 
competitive stance in areas such as pricing, advertising, new product or service introductions, and market scope. Competitive inertia reflects the number of market-oriented changes a company makes in trying to attract customers and outmaneuver competitors. Inertia is considered high if companies make few changes in competitive practices compared with the changes of their rivals of similar scale. Miller and Chen (1994) argue that inertia is driven by a motivational component (e.g., incentive to act, past performance, reinforcements, scanning and search, power, politics and managerial attributions, market growth), a knowledge component (e.g., awareness of action requirements and alternatives, market diversity, competitive experience), and a capability component (e.g., the constraints on managerial action, age and size, performance consequences of inertia). The authors assessed these three sources of inertia, respectively, by past performance and market growth, by competitive experience and diversity of the market environment, and by company age and size. The results of Miller and Chen's (1994) study indicate that good past performance contributes to competitive inertia, whereas a diversity of markets discourages competitive inertia.

The effects of inertia are also debated in the literature. In simpler and more stable environments, inertia may facilitate a more effective and economical use of managerial skills and resources and enable managers to concentrate on the most important decisions (Miller and Friesen 1984). Inertia also minimizes the costly blunders that come from making changes when complete information is unavailable (Hannan and Freeman 1984). But in more complex environments, competitive inertia as a form of a low level of market-oriented activity can severely retard adaptation in contexts that pose a wide variety of competitive threats. 
Rigidity is similar to inertia. Flexibility refers to the decision-making processes that use more information, create systems to promote debate and information sharing, and use a decentralized method of control over team decision-making processes, while rigidity is just the opposite (Hitt, Ireland, and Hoskisson 1999). Rigidity is a restriction of information and constriction of control within a group (Harrington, Lemak, and Kendall 2002). Rigidity theory concerns how organizations cope with a threat or crisis in complex environments (Staw, Sandelands, and Dutton 1981). Threat refers to an environmental event that has impending negative or harmful consequences for the entity. A general threat-rigidity effect occurs across individual, group, and organizational levels.

Empirical studies have suggested restricted information processing and constriction of control under threat conditions (Staw, Sandelands, and Dutton 1981). These studies have explored possible mechanisms underlying such a multiple-level effect as well as the possible functional and dysfunctional consequences. The individual effects include the link between threat situations and psychological stress and anxiety; the nature of cognitive manifestations of stress, anxiety, and arousal; the link between cognitive manifestations of stress, anxiety, and arousal; and properties of individual behavior. Group effects focus on the trade-off between external and internal attribution and the increased versus decreased cohesiveness in the teams. There are three consequences of threat at the organization level. First, due to an overload of communication channels, reliance on prior knowledge, and a reduction in communication complexity, there may be a restriction in the information-processing capacity of the organization. Second, due to centralization of authority and increased formalization of procedures, there may be a constriction in control. Third, there may be increased efforts to conserve resources within the system through cost cutting and efforts for greater efficiency. 
Threat-rigidity theory suggests that a threat to the vital interests of an entity leads to forms of rigidity. The rigidity may either be adaptive or maladaptive, depending on the condition. Rigidity as the only type of response to perceived threat results in a missed opportunity (Barnett and Pratt 2000). Rigidity effects have their source in organizational members' information insufficiencies, confusion, incapacities for rapid response, desires to avoid blame, and misallocation of attention between internal and external environments. Inherent in the rigidity reaction are excessive, dysfunctional levels of fear and anxiety as well as arousal and stress.

Barnett and Pratt (2000) present an opposing viewpoint. In their study of organizational crisis, they suggest that latent threats can generate functional levels of fear, anxiety, arousal, and stress, which may motivate organizational adaptation as well as longterm change involving learning and renewal. To the extent that renewal processes become institutionalized, it follows that organizational lifetimes are lengthened. Therefore, on the one hand, crisis may produce a threat-rigidity effect that restricts opportunities for organizational development or survival. On the other hand, crisis can stimulate organizational experimentation that may result in adaptation, learning, improvement, and longevity.

How does an event that has potentially negative or harmful consequences for the vital interests of a group affect the group's behavior? Griffin, Tesluck, and Jacobs (1995) suggest that groups tend to respond to threatening situations rigidly by becoming less open to change; less accepting of new ideas; and more uniform in their behavior, attitudes, and beliefs. According to Staw, Sandelands, and Dutton's (1981) threat-rigidity model, threatening situations may increase uniformity in attitudes and beliefs within groups through three processes. First, threat may influence individuals' information-processing capacities so that 
they ignore or screen out novel beliefs, opinions, and new perspectives, which results in high uniformity. Second, frequent interaction among group members during the threat entails intragroup processes that may develop cohesiveness and liking among group members. Third, attitudes may become more uniform because of the deliberate actions of group members and leaders in order to achieve group consensus.

Harrington, Lemak, and Kendall (2002) conduct an empirical study on how newly formed teams respond in threatening situations. The competitive environment is growing increasingly complex, uncertain, and adverse. An adverse environment refers to an environment that is perceived as having relatively high uncertainty. It may include unexpected, unpredictable, or fast-paced change, or it may appear threatening to the team. Harrington, Lemak, and Kendall (2002) argue that flexibility in decision-making processes is the key to effectively interacting with the environment in terms of adaptation, innovation, and speed. A newly formed team is a group that may or may not be familiar with one another and may not have worked together in this same project area. The threat-rigidity theory and groupthink research has suggested that the decision-making groups in adverse environments may reduce their flexibility, thereby sealing off new information and controlling deviant responses (Staw, Sandelands, and Dutton 1981). Hence, although decision-makers in an adverse environment should develop decision-making processes that feature decentralized control, openness to new ideas, and benefits from diversity within team members (Sharfman and Dean 1997), they might rely on well-learned responses, restrict information processing, and constrict decision control.

Is it the flexibility or rigidity of the decision-making process that affects the ability of an organization to adapt to and survive in an uncertain and often adverse environment? Hitt, 
Ireland, and Hoskisson (1999) suggest that teams with an externally attributed threat use a more flexible decision-making process, whereas teams with an internally attributed threat use a more rigid decision-making process. Their results show that the groups with either a higher level of threat or an internal attribution of the threat use more rigidity in their decisionmaking processes.

In the NPD literature, capability-rigidity theory is the most influential rigidity theory. Leonard-Barton (1992) examines the nature of the capabilities of a firm, focusing in particular on their interactions with new product and process development projects. Capabilities are defined as clusters of knowledge and skills in people, distinct technical systems and managerial systems, all of which are deeply rooted in values. The first dimension, knowledge and skills, encompasses both firm-specific techniques and scientific understanding. The second dimension, technical systems, includes both information and procedures. The third dimension, managerial systems, represents formal and informal ways of creating and controlling knowledge (e.g., incentive systems, reporting structures). The fourth dimension, values and norms, includes the value assigned within the company to the content and structure of knowledge and the means of collecting and controlling knowledge. All four capability dimensions reflect accumulated behaviors and beliefs based on early corporate successes. A capability is an interrelated, interdependent knowledge system. Each capability dimension is supported by the other three. The four dimensions vary in ease of change. From technical to managerial systems, skills, and then values, the dimensions are increasingly less tangible, less visible, and less explicitly codified. Capabilities are institutionalized (Zucker 1977). Because capabilities are a collection of knowledge sets, they are distributed and constantly enhanced by multiple sources. 
Leonard-Barton (1992) argues that traditional capabilities have a downside, rigidities, that inhibits innovation. How to take advantage of capabilities without being hampered by their dysfunctional side is a paradox that new product managers must face. By responding to environmental and market changes, development projects become the focal point for tension between innovation and the status quo, because effective competition occurs with innovation that exploits carefully developed capabilities (Quinn 1980). Institutionalized capabilities may lead to incumbent inertia (Lieberman and Montgomery 1988). Technological discontinuities can enhance or destroy existing competencies within an industry (Tushman and Anderson 1986). Organizations then struggle whether to maintain, renew, or replace core capabilities. Therefore, managers of such projects face a paradox: capabilities simultaneously enhance and inhibit development. Rigidities hamper innovation in the development projects, especially along the values dimensions. The very same values, norms, and attitudes that support a capability and thus enable development can also constrain it. Four ways to address the paradox: (1) abandonment, (2) recidivism, (3) reorientation, and (4) isolation.

However, Leonard-Barton's (1992) capability-rigidity framework lacks specific details in how organizational capabilities enhance and inhibit development and how the four strategies can resolve the paradox. In addition, there has been very little empirical study of these theoretical propositions. This dissertation attempts to take a pioneering step by exploring one particular organizational capability $-\mathrm{MO}$ and its relationship to new product innovation - with a view to examining whether this particular capability leads to rigidity outcomes in the form of competence traps that affect the firm's NPD efforts. 
After reviewing the inertia and rigidity theory, I continue to explore literature that is specifically pertinent to understanding how organizational learning may lead to negative outcomes and how rigidities can negatively affect the learning process.

\subsubsection{Learning Traps}

According to Crossan, Lane, and White (1999), the learning process may run the risk of becoming irrelevant and may even obstruct the feed-forward learning flows after the learning has become institutionalized at the organization level. Inertia and rigidity may block the learning process in what is known as learning myopia. There are three forms of learning myopia. The first form of myopia is the tendency to ignore the long run. This type of organizational learning emphasizes the short run, and therefore long-run survival is sometimes endangered. The second form of myopia is the tendency to ignore the big picture. This type of organizational learning pertains to the near neighborhood, and survival of more encompassing systems is sometimes endangered. The third form of myopia is the tendency to overlook failures. This type of organizational learning focuses on the lessons gained from success. Thus, organizations are likely to underestimate the risks of failure.

March (1991) studies how organizational learning is trapped by its inertia and rigidity. He suggests that exploration and exploitation coexist in the organizational learning process. Exploration includes search, variation, risk taking, experimentation, play, flexibility, discovery, and innovation. The essence of exploration is experimentation with new alternatives, but its returns are uncertain, distant, and often negative. Exploitation includes refinement, choice, production, efficiency, selection, implementation, and execution. The essence of exploitation is the refinement and extension of existing competences, 
technologies, and paradigms; its returns are positive, proximate, and predictable. Adaptive learning that engages in exploration to the exclusion of exploitation is highly likely to lead to the suffering of high experimentation costs without gaining many of its benefits because there are too many undeveloped new ideas and too little distinctive competency. Conversely, learning that engages in exploitation to the exclusion of exploration is highly likely to lead to the traps of suboptimal stable equilibrium.

Both exploration and exploitation are essential for organizations, but they compete for scarce resources. The process for allocating resources between them embodies intertemporal, interinstitutional, and interpersonal comparisons, as well as risk preferences (March 1991). Therefore, maintaining an appropriate balance between exploration and exploitation is a primary factor in system survival and prosperity. In studies of organizational learning, the problem of balancing exploration and exploitation is exhibited in distinctions between the refinement of an existing technology and the invention of a new one. It is clear that exploration of new alternatives reduces the speed with which skills at existing ones are improved, where improvements in competence at existing procedures make experimentation with others less attractive (March 1991). All of this makes finding an appropriate balance particularly difficult. Effective selection among forms, routines, or practices is essential to survival, as is the generation of new alternative practices, particularly in a changing environment.

Frequently, organizations are trapped by exploitation. Compared to returns from exploitation, returns from exploration are systematically less certain, more remote in time, and organizationally more distant form the locus of action and adaptation (March 1991). Thus, the certain speed, proximity, and clarity of feedback tie exploitation to its consequence 
more quickly and more precisely than is the case with exploration. In an adaptive process, advantages of exploitation cumulate more rapidly than those of exploration. Therefore, learning and imitation inhibit experimentation.

However, what is good in the short run is not always good in the long run (Levinthal and March 1993; March 1991). Positive local feedback produces strong path dependence, which may lead to suboptimal equilibriums. The competence in an inferior activity likely becomes great enough to exclude superior activities with which an organization has little experience. But long-run intelligence depends on sustaining a reasonable level of exploration, not exploitation. Therefore, these tendencies to increase exploitation and reduce exploration make adaptive processes potentially self-destructive, which are referred to as learning traps.

Learning traps are situations in which organizations become trapped in one or more of several learning dynamics that self-destructively lead to excessive exploration or excessive exploitation (Cyert and Williams 1993; Levinthal and March 1993). These dynamic distortions of the exploitation-exploration balance are perverse. Organizations are trapped by the imbalance between exploration and exploitation in the learning process.

Although Levinthal and March (1993) made the first attempt to conceptualize the high-level learning traps in the literature, they fail to provide a systematic theory about learning traps. They mention many different types of traps existing in the learning processsuch as competence, power, learning, failure, and success - but fail to compare and contrast the traps on the basis of on possible theories. The result is that several concepts seem to overlap. However, Levinthal and March's (1993) contribution is the introduction of a realization that organizational learning is imperfect. Learning processes are subject to some 
important limitations and have their own traps. It is therefore important for organizations to make an effort to improve learning capabilities and reduce learning traps (King and West 2002).

Competency traps occur when organizations engage in activities at which they are more competent with greater frequency than they engage in activities at which they are less competent (Levinthal and March 1993). The self-reinforcing nature of learning makes it attractive for an individual or organization to sustain current focus. The result is that distinctive competence is accentuated, and organizations become specialized in niches in which their competencies yield immediate advantage. Learners become increasingly removed from other bases of experience and knowledge and more vulnerable to change in their environments (Levinthal and March 1993).

Power traps occur when organizations use their power to impose environments, which likely results in atrophy of their capabilities to respond to change in the long run. Because organizational power enables an organization to change its environments rather than adapt to them, it is a short-run asset but potentially a long-run liability (Levinthal and March 1993).

Failure traps are situations in which organizations turn into frenzies of experimentation, change, and innovation by a dynamic of failure. New ideas and technologies fail and are replaced by other new ideas and technologies, which also fail (Levinthal and March 1993).

Success traps are situations in which organizations discover the short-term virtue of local refinement and the folly of exploration. As they develop greater competence at a particular activity, they engage in that activity more. Thus, success leads to more exploitation and reduces the level of exploration (Levinthal and March 1993). 
All these traps are standard, potentially self-destructive products of learning. In my opinion, there is only one type of learning trap: the competency trap. Power, failure, and success traps all belong to the competency trap. Organizations engage in some specific activities with greater frequency due to their power, failure, or success experience.

Similar to Levinthal and March's idea (1993), Lant and Mezias (1990) suggest that when established firms face the challenge of managing entrepreneurial strategies to respond effectively to major environmental changes, there are three learning strategies available: (1) innovative, (2) imitative, and (3) fixed. When the environment changes, lessons learned from past experience can often result in two types of learning traps. First is the oscillation trap, which refers to the situation in which the optimal solutions are frequently untenable in the real world. A different adaptive strategy should be used when the level of ambiguity changes in the environment. Second, the follow-the-leaders trap occurs when imitative firms tend to perform poorly after discontinuous change because the largest firm in the population no longer provides a good signal to follow.

Ahuja and Lampert (2001) define three traps that inhibit breakthrough inventions: (1) the familiarity trap (favoring the familiar), (2) the maturity trap (favoring the mature), and (3) the propinquity trap (favoring search for solutions near to existing solutions). They suggest that firms can overcome these traps and create breakthrough inventions by experimenting with novel technologies (e.g., those with which the firm lacks prior experience), emerging technologies (e.g., recent or newly developed in the industry), and (3) pioneering technologies (e.g., those that do not build on any existing technologies).

In this dissertation, I am interested in competency traps in the NPD process. In the following section, I attempt to conceptualize competency traps in a systematic way. 


\subsubsection{Competency Traps}

Competence (the power to do something) is the ability to sustain the coordinated deployment of assets in a way that helps a firm achieve its goal (O'Driscoll, Carson, and Gilmore 2001). Competence building is any process by which a firm achieves qualitative changes in its existing stock of assets and capabilities, including new abilities to coordinate and deploy new or existing assets and capabilities in ways that help the firm achieve its goal.

Competency traps occur when past favorable performance with an inferior procedure leads an organization to accumulate more experience with it, thus keeping experience with a superior procedure inadequate to make its use rewarding (Levinthal and March 1993). The problem of competency traps is that they likely lead to maladaptive specialization if newer routines are better than older ones. In the technology development process, new procedures are always after the old procedures. The old procedures may exhibit persistent tendency because learning inertia makes it difficult for a firm to move away from the competences that it has previously developed. The difference between the impact potential of alternatives and the impact of the older competence is strength of such persistence or inertia in inferior procedures.

How do competency traps act upon the organizational operation? How can firms identify whether they are in these traps? After a careful reading of existing literature, in this dissertation, I conceptualize the competency traps from three different perspectives-(1) cognition, (2) content, and (3) path of organizational learning - and rename them vision trap, technology trap, and routinization trap. 
Vision trap. First, what kind of cognition or vision do the firms in the competency traps have? From the cognitive perspective, competency traps may affect the cognition and visions of individuals and groups in firms. It is highly possible for firms to be overconfident with their existing competences because of past favorable performance. The inertia or persistence toward old procedures or competences is driven by favorable outcomes. Firms in competency traps are very confident of their ability to succeed in the future, which leads them to fail both to develop more creative alternatives and to give adequate thought to tradeoffs (Hammond, Keeney, and Raiffa 1999). The overconfidence makes firms find a comfortable zone to work on and avoid upsetting it. Such confidence may create a strong, self-perpetuating cognition, which leads to a discounting of weak signals in the environment, where those signals threaten the source of the confidence (Fiol and Lyles 1985; King and West 2002; Levinthal and March 1993; Levitt and March 1988). Success leads to arrogance, which triggers denial of the need to change and perhaps even failure (Levinthal and March 1993). Confidence traps firms into adhering to strategies or processes of fading value. Therefore, whether organizations are overconfident with their process or procedure is an important dimension of competency traps.

Technology trap. Second, what kind of content do the firms in competency traps work on, mature technology or new technology, familiar technology or unfamiliar technology? From an institutional perspective, firms in competency traps tend to rely on the legitimacy of current existing mature and familiar technologies. According to Levinthal and March (1993), organizations use specialization to facilitate learning from experience. Firms in competency traps become specialized in what they know and what they have. They become rigid to new and unfamiliar technology. 
Mature technologies are relatively well known in the industry (Ahuja and Lampert 2001). Because of their greater reliability, mature technologies are more likely to have an advantage in the short term than more recently developed and less tested approaches. In addition, the legitimacy of mature technologies makes the products easier to sell to customers. This short-term favorable outcome may lead firms to rely on mature technologies. Such reliance prevents the firms from identifying the significant opportunity of early emerging technologies, some of which may make fundamental breakthroughs later (Ahuja and Lampert 2001). Once the new emerging technologies take off, firms that rely on mature technologies will be trapped by inexperience and will lag behind firms with newly emerging technologies.

Firms in competency traps also tend to select and adhere to technologies that are familiar. Information in familiar forms can be processed more quickly and familiar technologies learned more quickly. What is familiar is usually efficient. New information or new technologies are less efficient. Then, pursuit of the new threatens normal levels of return. Increased specialization reduces the motivation to move other technology bases (Levinthal and March 1993; Levitt and March 1988). The self-reinforcing process crystallizes current practice and forestalls change (King and West 2002; Stinchcombe 1986). If a new technology emerges, firms may be trapped by this maladaptive specialization (Ahuja and Lampert 2001).

Therefore, the use of familiar and mature technology is another important dimension of competency traps.

Routinization trap. Third, from a path-dependence perspective, firms in competency traps tend to follow formalized and standardized processes, procedures, or routines. 
According to Levinthal and March (1993), organizations also use simplification to facilitate learning from experience. A means of increasing the effectiveness of learning is to simplify natural experience by inhibiting learning in one part of an organization in order to make learning more effective in another part. Formalized and standardized procedures simplify the routine and improve firms' competency, which leads to high efficiency and successful outcomes. However, in dynamic environments, formalized or standardized procedure or routine may be far from optimal (Arthur 1984; Levitt and March 1988). The inertia from fixed procedure may trap the firms in a changing environment. Therefore, routinized procedure is the third important dimension of competency traps.

In summary, a competency trap can be defined along three dimensions: (1) vision trap (bias or overconfidence that may lead to an inability to see weaknesses of NPD processes), (2) technology trap (persistence towards using mature and familiar technology in new product development), and (3) routinization (inertia of using formalized and standardized procedures or resistance to procedure change). The three dimensions are all interrelated.

\subsubsection{Summary}

Organizational learning is one of the most important activities that occurs within organizations. Bell, Whitewell, and Lukas (2002) review four schools of thought that pertain to organizational learning. They consider MO and NPD as two areas that have most fully embraced the organizational learning concept. Kohli and Jaworski (1990) and Jaworski and Kohli (1993) define MO from the marketing information-processing perspective. The marketing information processing in market-oriented firms includes: marketing information generation, dissemination, and responsiveness. Therefore, MO is inherently a learning 
orientation (Slater and Narver 1995). Bell, Whitwell, and Lukas (2002) list how informationprocessing capabilities affect invention and innovation — in other words, how MO affects new product innovation — as the most important future research topic. This dissertation intends to study this research question by understanding the role of competency traps in the new product learning process.

\subsection{Literature Review on Entrepreneurial Orientation}

\subsubsection{Entrepreneurship and Corporate Entrepreneurship}

Entrepreneurship has been linked with innovation in the literature (e.g., Damanpour and Evan 1984; Wiklund 1999; Zahra and Covin 1995) and referred to as the "parent of innovation" (e.g., Miles and Arnold 1991). Without entrepreneurship, business and society would be neither dynamic nor adaptive but stagnant. Entrepreneurship leads firms to seek innovative and flexible means to exploit opportunities and achieve desired objectives (e.g., Khandwalla 1977; Miles and Arnold 1991).

Schumpeter (1934) defines entrepreneurship as processes or activities designed to seize market opportunities through creative destruction. Harwood (1982) defines entrepreneurship as the process of assembling resources to create and build independent enterprises, which encompasses creativity, risk taking, and innovation. Therefore, the concept of entrepreneurship is related to new business entry and is concerned primarily with questions such as, what business do we enter? and how do we make the new business succeed? (e.g., Richard et al. 2004).

Despite general agreement on the effects of entrepreneurship, there is some debate regarding the definition and operationalization of entrepreneurship. The various 
conceptualizations include individual entrepreneurs or small firms, corporate venturing or intrapreneurship and strategic renewal (Stopford and Baden-Fuller 1994), and various types of behavior by established firms (Covin and Slevin 1991; Miller 1983).

Traditional entrepreneurship research emphasizes the individual-level entrepreneurs, such as traits of the individual and small firm (Baron and Markman 2000; Bhide 2000; Kets de Vries 1977; McGrath, MacMillan, and Scheinberg 1992). However, entrepreneurship research has increasingly extended to the firm level: corporate entrepreneurship (Barringer and Bluedorn 1999; Floyd and Lane 2000; Stopford and Baden-Fuller 1994). Entrepreneurs create and run their ventures to develop a market niche with new products or services or to substitute for established players by offering better quality, cheaper price, and so on. Corporate entrepreneurship seeks to encourage entrepreneurial behavior within established firms (Covin and Slevin 1991; Miller 1983; Zahra 1993a, b). To deal with problems, such as making changes in the marketplace to avoid stagnation and decline or perceived weakness in the traditional methods of corporate management (Kuratko, Nontagno, and Hornsby 1990), corporations to may seek to be entrepreneurial by running a new business within ongoing enterprises. Corporate entrepreneurship takes different formats, such as internal innovation; joint ventures or acquisitions; strategic renewal; product, process, and administrative innovations; and diversification (Dess et al. 2003).

Corporate entrepreneurship is defined as "the process whereby an individual or a, or instigate renewal or innovation within that organization" (Sharma and Chrisman 1999, p.18). The creation of corporate entrepreneurship activity is difficult since it involves radically changing internal organizational behavior patterns. Corporate entrepreneurship can be divided into three categories: (1) the creation of new businesses within an organization, or 
intrapreneurship; (2) the transformation or renewal of an existing organization, and (3) Schumpeterian changes in the rules of competition (Stopford and Baden-Fuller 1994).

At the corporate entrepreneurship level, entrepreneurial orientation is viewed as the most important and popular concept in the literature (Covin and Slevin 1991; Lee, Lee, and Pennings 2001; Lumpkin and Dess 1996). It is important for firms to be entrepreneurial oriented for the following reasons. First, as a unique business philosophy or culture, entrepreneurial orientation (EO) influences how firms perceive certain situations and what strategic decisions they take (Frese, Brantjes, and Hoorn 2002). An EO suggests that organizations must constantly seek to exploit the dynamics of their macroenvironment and task environments. Second, empirical evidence indicates that financially successful firms tend to exhibit an entrepreneurial posture in hostile environments (Covin and Slevin 1989). Thus, an EO may prepare firms for the appropriate strategic response to organizational crises caused by environmental turbulence (Khandwalla 1977).

In the following section, I review the literature on EO.

\subsubsection{Definition of Entrepreneurial Orientation}

Many scholars have defined EO; for example, (Morris and Paul 1987) define EO as "the propensity of a company's top management to take calculated risks, to be innovative, and to demonstrate proactiveness." However, the most influential definition is that of Lumpkin and Dess (1996), who define EO as the organizational process, methods, decisionmaking activities, and styles used to implement innovation or lead to new entry. Entrepreneurial orientation reflects how a firm operates rather than what it does, and it 
represents how a firm is organized in order to discover and exploit opportunities (Wiklund and Shepherd 2003).

Lumpkin and Dess (1996) build their definition based on two influential studies: those of Covin and Slevin (1991) and Miller (1983). These two studies first suggested innovation, risk taking, and proactiveness as key dimensions of entrepreneurial activity. Lumpkin and Dess (1996) incorporate two additional dimensions: (1) autonomy (propensity to act autonomously) and (2) competitive aggressiveness (tendency to act aggressively toward competitors).

Innovativeness is the tendency to actively engage in and support new ideas, experimental and creative process that may result in new products, services or technological processes (Lumpkin and Dess 1996). Risk taking concerns the willingness to take businessrelated chances with regard to strategic actions in the face of uncertainty (Lumpkin and Dess 1996). Proactiveness refers to forward-looking, first-mover-advantage-seeking efforts to shape the environment by introducing new products or processes ahead of competition (Lumpkin and Dess 1996). Autonomy is the ability and will to be self-directed in the pursuit of opportunities (Lumpkin and Dess 1996). Competitive aggressiveness is the tendency of firms to assume a combative posture toward rivals and to employ a high level of competitive intensity in attempts to surpass them (Lumpkin and Dess 1996). Therefore, an EO consists of process, structures, and/or behaviors that can be described as aggressive, innovative, proactive, risk taking, or autonomy seeking.

Among these five dimensions of EO, only the first three are most commonly cited in the literature: (1) innovativeness, (2) risk taking, and proactiveness. Entrepreneurial orientation is a process construct, grounded in the strategic-choice perspective, that promotes 
initiatives (Burgelman 1983). A strategic posture that emphasizes risk taking and proactiveness suggests that a management group needs high levels of trust and interpersonal communication. Both the risk taking and the proactiveness dimensions of EO require a firm to make quick decisions and to aggressively compete by implementing bold and risky strategies in the face of uncertainty (Richard et al. 2004).

\subsubsection{Measurement of Entrepreneurial Orientation}

Entrepreneurial orientation is a firm-level construct (Covin and Slevin 1991). Miller (1983) and Covin and Slevin (1989) suggest that entrepreneurial orientation is a onedimensional construct. All dimensions of EO are interrelated and overlapped. Therefore, they collapse the EO dimensions into one. However, Lumpkin and Dess (1996) argue that the EO dimensions can vary independently of one another, because it might be difficult to determine the sources of variability in a firm's EO and how those differences contribute to or detract from performance. A firm may be quite innovative and at the leading edge in its manufacturing operations but rather conventional in all of its other value activities (Lyon, Lumpkin, and Dess 2000). Lumpkin and Dess (1996) develop the two additional dimension scales and provide theoretical support and empirical evidence that EO dimensions may vary independently depending on the organizational and environmental context (Lyon, Lumpkin, and Dess 2000).

Several studies investigate the issues of validity, reliability, and triangulation in EO research. Lyon, Lumpkin, and Dess (2000) conduct a comprehensive review on a set of recent studies that employ different approaches to EO measurement. The studies include articles published between 1995 and 2000 in Academy of Management Journal, Journal of 
Management, Strategic Management Journal, Journal of Business Venturing, and Entrepreneurship Theory and Practice. According to their findings, the highest incidence of reliability testing (by Cronbach's alpha) occurs in studies that employ managerial perceptions to measure one or more EO dimension, which indicates good internal consistency reliability. The lowest incidence of testing for reliability was for constructs measured using resource allocations such as the percentage of scientist, R\&D intensity, and financial leverage. Therefore, a triangulation of methods is suggested to improve the measurement.

Kreiser, Marino, and Weaver (2002) use data from 1067 firms in six countries to clarify the psychometric properties of the EO measure. The results of a confirmatory factor analysis in LISREL supported three subdimensional models: (1) innovation, (2) proactiveness, and (3) risk taking. Correlation analysis revealed that the three subdimensions of EO can vary independently of one another in many situations. Kreiser, Marino, and Weaver's (2002) study and multicountry sample strongly support the cross-cultural validity of Covin and Slevin's EO scale.

\subsubsection{Entrepreneurial Orientation and Performance}

Entrepreneurship scholars have tried to explain performance by focusing on a firm's strategic EO (Wiklund and Shepherd 2003). Entrepreneurial orientation captures an important aspect of how a firm is organized, and it facilitates firm action on the basis of early signals from the internal and external environments (Lumpkin and Dess 1996). Therefore, EO can explain, in part, the managerial processes that enable some firms to be ahead of their competition. 
Previous empirical results provide support for a positive relationship between EO and performance (e.g., Wiklund 1999; Wiklund and Shepherd 2003; Zahra and Covin 1995). An EO can assist companies in many ways. The innovativeness dimension of EO leads firms to create and introduce new products and technologies, which may generate extraordinary economic performance; these have even been described as the engines of economic growth (Brown and Eisenhardt 1995). Proactive dimensions of EO can create first-mover advantages, target premium market segments, and skim the market ahead of competitors (Zahra and Covin 1995). Firms may have a chance to control the market by dominating distribution channels and establishing brand recognition. Risky strategies leading to performance variation may be more profitable in the long run (McGrath 2001).

However, the EO-performance relationship is contingent on the internal and external environments (e.g., Covin and Slevin 1989). The contingence relationship has been largely ignored in the literature. Lumpkin and Dess (1996) call for research to investigate how internal firm characteristics moderate and mediate the EO-performance relationship. Wiklund and Shepherd (2003) study how knowledge-based resources, applicable to the discovery and exploitation of opportunities, moderate the EO-performance relationship. They argue that EO captures a firm's organization toward entrepreneurship and can enhance other firm resources. Unless the firm is willing to grasp and enthusiastically pursue these opportunities, the knowledge-based resources are likely to be underused. They find support for the interaction between $\mathrm{EO}$ and knowledge-based resources.

In conclusion, entrepreneurship literature calls for research to explore the underlying processes of how entrepreneurial activity affects performance in established firms (Lumpkin 
and Dess 1996). This dissertation responds to that call by examining how EO can help firms achieve high innovative outcomes. 


\section{CHAPTER 3: THEORETICAL FRAMEWORK AND HYPOHTESES}

Figure 1 depicts the theoretical framework that will be studied and tested in this dissertation. The theoretical framework for this study draws on capability-rigidity, entrepreneurship, and network theories. Marketing literature suggests that a balance between radical innovation and incremental innovation (across a firm's portfolio of new product efforts) may lead to optimal new product success (e.g., Wind and Mahajan 1997). As posited in the model, because MO produces primarily adaptive learning insights, it increases incremental product innovation, which can increase NPD efficiency. Simultaneously, as with any other capability, MO can also lead to inertia and rigidity. In dynamic environments, this inertia and rigidity may create competency traps (e.g., relying on a previously successful NPD process rather than adopting new approaches), which in turn decrease new product creativity. Yet new product creativity is positively related to radical innovation. In order to reduce competency traps and enhance the firm's ability to develop innovative new products, this model proposes that firms should seek to enhance two complementary assets to MO: (1) entrepreneurial orientation and (2) network learning. These may help reduce MO's tendency to create learning traps by enhancing a firm's ability to recognize new opportunities and create novel perspectives, which can reduce competency traps and increase radical new product innovation. 
Figure 3.1 Research Model and Hypotheses

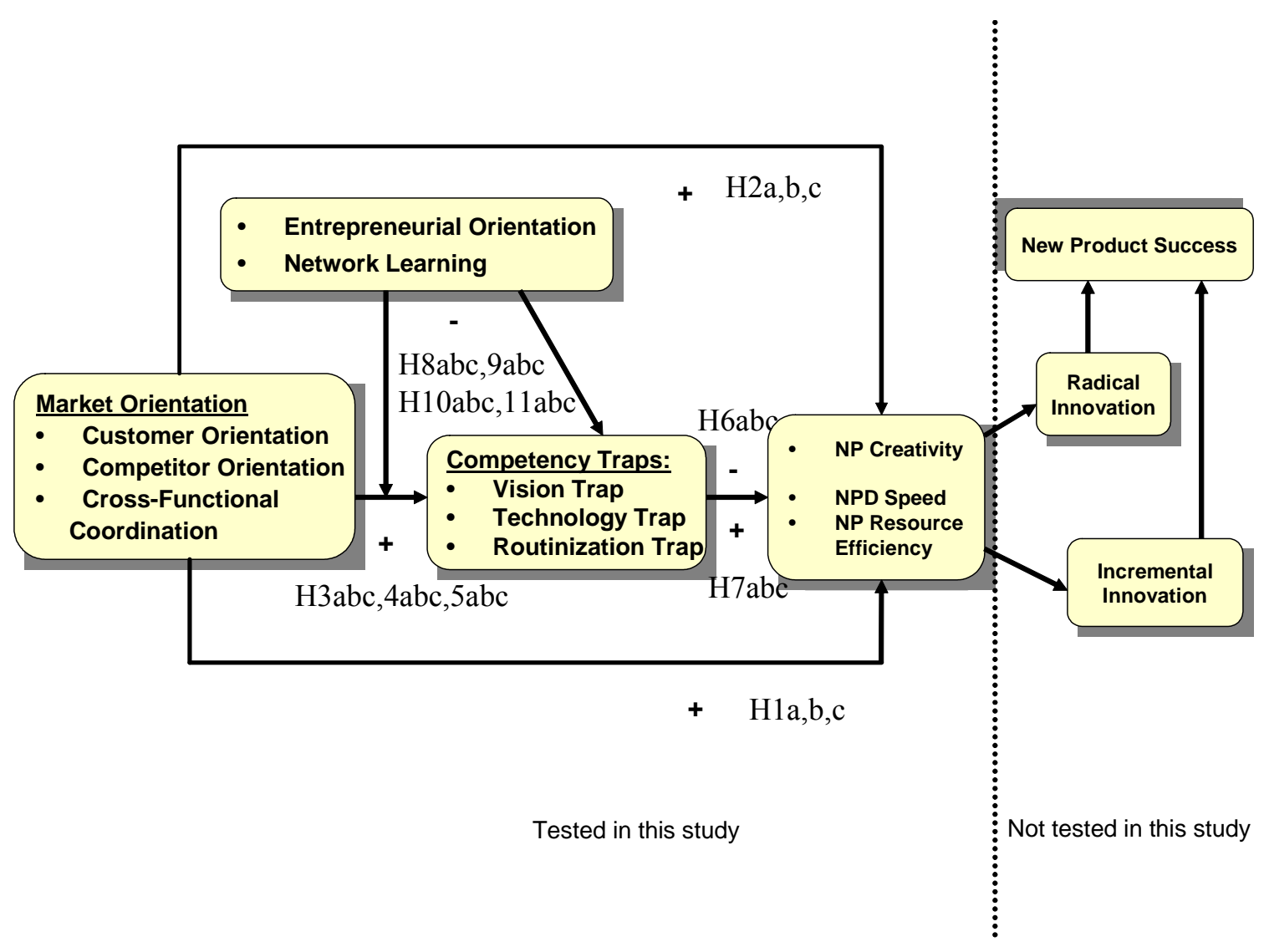




\subsection{Theoretical Framework}

\subsubsection{Capability-Rigidity and Institutional Theories}

According to section 2.3.3, the capability-rigidity framework introduces a paradox to the innovation literature. Leonard-Barton (1992) suggests that although organizational capabilities as a collection of knowledge sets enhance innovation, at the same time, they also hinder it. This negative side of organizational capabilities are rigidities (Leonard-Barton 1992). In order to be efficient and effective in innovation competition, organizations exploit existing capabilities (Quinn 1980). However, environmental and market changes trigger tension between a need for innovation and the certainty and efficiency of the status quo in NPD projects. Organizations therefore struggle with the question of whether to maintain, improve, or replace core capabilities.

The very same values, norms, and attitudes that support a capability can also constrain it. How does this happen? Because institutionalized capabilities may lead to incumbent inertia (Lieberman and Montgomery 1988). Prevailing operational routines may trap organizations into local search routines and limit an organization's ability to innovate, imitate, and implement process improvements (Dickson 1992). This is often because human behavior makes it difficult to shift mentally from a successful but inefficient habitual activity (i.e., from an opportunity-cost perspective relative to an optimal solution for a new set of circumstances) to a more efficient way of solving problems or achieving a goal (Luchins and Luchins 1970). Therefore, an organization may become functionally fixed as a result of mental inertia. Furthermore, changing routines within an organization may be resisted because it can provoke conflict between functions and factions that have learned to work together over time around a particular process organization (Nelson and Winter 1982). 
In this dissertation, I test capability-rigidity theory by examining whether $\mathrm{MO}$, as one particular organizational capability important in the NPD process, enhances new product efficiency but at the same time leads to competence traps—one type of inertia and rigidity— that inhibit new product creativity.

\subsubsection{Organizational Learning Theory}

According to section 2.3.1, organizational learning is particularly important for innovation and NPD in that the nature of NPD requires a departure from existing norms and routines, a shift that demands learning at the individual, team, and even organizational levels (Akgun, Lynn, and Reilly 2002; Bell, Whitewell, and Lukas 2002; Lynn, Skov, and Abel 1999; Methe, Toyama, and Miyabe 1997). From a cognitive perspective, organizational learning may occur in two ways: (1) single-loop learning and (2) double-loop learning (Arthur and Aiman-Smith 2001; Senge 1990; Slater and Narver 1995). Single-loop learning is a routine, incremental, conservative process that serves to maintain stable relations and sustain existing rules (Argyris and Schon 1978; Arthur and Aiman-Smith 2001; Hedberg, Nystrom, and Starbuck 1976). The outcome of single-loop learning is incremental change or adaptation carried out to further exploit existing technologies and processes in ways that do not alter underlying assumptions or values (Argyris and Schon 1978; Cyert and March 1963; March 1991; Mckee 1992; Sinkula 2002). However, according to capability-rigidity theory, when a capability is codified in information systems, operating procedures, mission statements, and routines, these memories may persist (Slater and Narver 1995). Unintended consequences may result. Capabilities may become rigidities that can inhibit innovation 
(Leonard-Barton 1992). In order to reduce or avoid such rigidities, double-loop learning can be a useful complement in organizations.

Double-loop learning concerns the search for and exploration of alternative routines, rules, technologies, goals, and purposes (Argyris and Schon 1978; Arthur and Aiman-Smith 2001; Hedberg, Nystrom, and Starbuck 1976; Mckee 1992). Second-order, or double-loop, learning sets new priorities and reexamines existing norms (Arthur and Aiman-Smith 2001). Double-loop learning enables organizations to break out of existing thought or behavior patterns by exploring qualitatively different ways of thinking and doing things. Double-loop learning is higher level and more cognitive than single-loop learning and aims at adjusting overall rules and norms rather than specific activities or behaviors (Foil and Lyles 1985; Mckee 1992). Therefore, double-loop learning is complementary to single-loop learning. According to March (1991), organizations must balance exploitation and exploration in their organizational learning because too much exploitation is unlikely to lead to doubleloop learning and too much exploration is too expensive. Very often organizations fall into competency traps as a result of inertia and rigidity in their organizational learning capabilities. Such inertia or rigidity leads the organization to become unwilling or unable to reject an existing capability even when a new capability may be more effective than existing ones. To reduce the prevalence of such adaptive learning traps, organizations must ensure that their networks include people with perspectives different from those of the dominant players in the organization (Slater and Narver 1995).

After integrating organizational learning theories and capability-rigidity theory, this dissertation argues that although MO as a capability fosters new product efficiency and incremental new product innovation, at the same time it leads to rigidities, which are 
competency traps that reduce new product creativity and radical innovation. In order to break inertia and rigidity, and thereby reduce competency traps, organizations should conduct double-loop learning for reorientation by developing other complementary capabilities, such as an EO and network learning. According to Slater and Narver (1995), MO may not encourage sufficient willingness to take risks. An EO not only increases a top management team's propensity for risk taking but also redirects the firm's information processes to be more sensitive to new opportunity recognition. In addition, MO may limit a company's focus to only the express needs of customers, which is only adaptive learning. In order to create double-loop learning, organizations must take advantage of other potential learning sources, such as suppliers, businesses in different industries, consultants, universities, and government agencies (Slater and Narver 1995). Such network learning extends a firm's search scope beyond customers and competitors to a wider range of external sources of information, which helps reduce the likelihood and impact of competency traps. Therefore, EO and network learning may reduce or negate the rigidity outcome of $\mathrm{MO}$ and enable an organization to engage in double learning that facilitates strategic reorientation.

\subsubsection{Dynamic Capabilities Theory}

Dynamic capabilities (DC) theory is built upon the theoretical foundations in economics provided by Schumpeter (1934), Penrose (1959), Nelson and Winter (1982), Teece (1988), and Teece, Pisano, and Shuen (1997). The theory develops a framework to explain whether distinctive and difficult-to-replicate advantages can be built, maintained, and enhanced; how firms first develop firm-specific capabilities; and how firms renew competences to respond to rapid shifts in the business environment. Dynamic refers to the 
capacity to renew competencies to achieve congruence with a changing business

environment (Eisenhardt and Martin 2000). Certain innovative responses are required when time-to-market and timing are critical to competitive success, the rate of technological change is rapid, and the nature of future competition and market are difficult to determine. Dynamic capabilities emphasize the key role of strategic management in appropriately adapting, integrating, and reconfiguring internal and external organizational skills, resources, and functional competences to match the requirements of a changing environment (Teece, Pisano, and Shuen 1997).

Dynamic capabilities theory is developed from the resource-based view (RBV) of the firm. Both theories posit that firms are heterogeneous in the strategic resources they control, but they approach resource mobility differently (firms can develop firm-specific capabilities, and they can keep renewing their competences to respond to rapid shifts in the business environment) (Teece, Pisano, and Shuen 1997). Because RBV theory posits that resources are stable and immobile, it cannot explain firm behavior and performance over time in a dynamic environment. According to DC theory, firms renew the capabilities required to acquired, develop, and reconfigure their resources, and this leads to resource mobility in the long run. Therefore, winners in dynamic market situations usually demonstrate timely responsiveness and rapid and flexible product innovation, coupled with management's ability to effectively coordinate and redeploy internal and external competences (Teece, Pisano, and Shuen 1997). The DC approach stresses the exploitation of existing internal and external firm-specific competences to address changing environments. As an emerging and potentially integrative approach, DC theory helps to understand the new sources of competitive advantage (Eisenhardt and Martin 2000). 
According to DC theory, firms' renewal capabilities lead to resource mobility in the long run (Teece, Pisano, and Shuen 1997). Managers contribute to renewal capabilities by building renewal mechanisms internally. If the mechanisms are distinctive and difficult to replicate, a firm can sustain superior profitability. If a business doesn't have distinctive capabilities and none of its rivals have a meaningful advantage, then the profits of the business will settle at the industry average (Porter 1980). At the same time, interdependency and complementarity between various firm resources and capabilities contribute to the inimitability of firm-specific resource bundles, which enhances the sustainability of any competitive advantage achieved (e.g., Helfat 1997).

Market orientation is viewed as an important knowledge-based capability that is rare, because of the difficulty and cost of obtaining such market-based knowledge, and potentially valuable. This is because it offers market-based insights that are not available to other firms (e.g., Hunt and Morgan 1995). However, complementary resources or capabilities are also required to enable the firm to gain maximum value and sustain innovation (Delmas 2002). Slater and Narver (1995, p. 71) suggest that EO and network learning are very important complementary capabilities to MO: "Market orientation without an entrepreneurial drive might focus the organization's efforts too narrowly and, at best, produce adaptive learning." Network learning may broaden the narrow construction of $\mathrm{MO}$ and enable a fresh perspective from strategic external partners. A failure to examine the impact of complementary resources and capabilities in the enabling of links between MO and NPP outcomes may explain why previous studies of the MO-NPP relationship have reported mixed empirical results.

Although Slater and Narver (1995) suggest that MO is insufficient to produce a learning organization and new product innovation if it is not complemented by 
entrepreneurship and network learning, there is no study that empirically tests this proposition. Therefore, this dissertation fills this research gap by providing empirical evidence concerning capabilities that are complementary to MO in the NPD process. Specially, the framework proposes that a combination of MO, EO, and network learning is a key driver of new product innovation. Entrepreneurial orientation and network learning are complementary capabilities to MO because they help market-oriented firms break the constraints of MO by providing the ability to recognize radical new opportunities and to create unique perspectives, which in turn reduces the risk of competency traps and increases new product innovation.

In the following section, I elaborate on the definitions and hypotheses.

\subsection{Hypotheses}

\subsubsection{Market Orientation}

Section 2.3.3.1 discusses the capability-rigidity theory of Leonard-Barton (1992). This theory argues that on the one hand, capabilities can have positive effects on NPD; on the other hand, they can also simultaneously create rigidities, which inhibit new product innovation. There is little empirical evidence available to test this theory and framework. This section develops arguments to support the capability-rigidity framework by selecting MO as a capability and elaborating on how MO can enhance incremental NPD and NPD efficiency, while also inhibiting radical NPD and new product creativity by facilitating the creation of competency traps. 


\subsubsection{The Positive Side of Market Orientation As a Capability}

Narver and Slater (1990) define MO from a cultural perspective as a combination of customer orientation, competitor orientation, and interfunctional coordination. Market orientation as a single-loop learning capability may lead to the exploitation of existing technologies, routines, and processes (Dickson 1992). In this dissertation, NPD efficiency is conceptualized in terms of NPD speed and the ratio of NPD resources consumed to outcomes achieved.

The link between customer orientation and NPD efficiency. Customer orientation occurs when firms engage in activities to understand their buyers in order to continually create superior value for them (Han, Kim, and Srivastava 1998; Narver and Slater 1990). From a learning perspective, highly customer-oriented firms may have well-defined learning boundaries and be able to search quickly, because customer preferences become internalized in both individual and organizational memories. According to behavioral economics (Cyert and March 1963), decision makers look in the "neighborhoods" of the past patterns when searching for information, because this kind of internal search is quicker than broader external searches. Therefore, a customer focus may constrain firms to search only within the boundary of "customers." Within the customer-bound search encouraged in the learning efforts of customer-oriented firms, managers are also more likely to focus on existing customers and to be bound by customers' ability to express needs and requirements (e.g., Slater and Narver 1998).

Products provided by highly customer-oriented firms may fit existing customer needs best. As a result, such firms' customer-directed goals and efforts to incorporate customer 
value in all value-offering decisions (Gatignon and Xuereb 1997; Griffin and Hauser 1993).

Highly customer-oriented firms should do a better job of identifying, structuring, prioritizing, and satisfying customers' needs than do less customer-oriented firms (Narver and Slater 1990). Such a customer focus may help firms capture existing market demands and reduce the potential risks of misfitting NPD resources to buyer needs (Li and Calantone 1998). Having a clear and superior understanding of customer expectations (Lee, Yang, and $\mathrm{Yu}$ 2001) helps customer-oriented firms set clear time and budget goals for NPD plans. It is less

likely that such firms waste time and NPD resources searching for inappropriate new product ideas and solutions. Their knowledge of customers should also enable customer-oriented firms to be more efficient in their test-marketing efforts. Therefore, customer orientation is positively associated with NPD efficiency because it enables managers to better focus NPD efforts and resource developments on the things that matter to customers. This leads me to posit that

\section{$H_{1 a}$ : A firm's customer orientation is positively associated with its NPD efficiency.}

The link between competitor orientation and NPD efficiency. Competitor orientation is the extent to which firms focus on learning about the resources, capabilities, motivations, and actions of their rivals, and it reflects their propensity to try to anticipate competitors' moves (Narver and Slater 1990). Highly competitor-oriented firms often deploy significant resources toward market scanning and competitor intelligence. Competitor-oriented firms make efforts to analyze competitors' strategies and identify their strengths and weakness (Han, Kim, and Srivastava 1998). Such efforts may increase firms' knowledge about 
competitors in terms of their resources, capabilities, strategies, and tactics (Katila 2002).

From a learning perspective, highly competitor-oriented firms may be able to search more quickly and efficiently, because knowledge about their competitors becomes internalized in both individual and organizational memories. When NPD search patterns established by a competitor-focus form the boundaries of search, this kind of internal search is quicker than external search.

Through competitor analyses, highly competitor-oriented firms may know, with respect to the competitors' product and service offerings, what works well for customers and where the competitors fail to meet customer requirements. They may therefore save time and resources in NPD activities by focusing only on elements of product offerings that seem to be important to customers, and thus avoid wasting time and resources engaging in NPD activities that target product elements that are less important to customers. Furthermore, since customer responses to new products are significantly affected by the available alternatives, firms with a deeper understanding of competitors are better able to develop and market new products that compare favorably to those of competitors. In addition, by understanding the benchmark of competitors' products, a firm with a strong competitor orientation is less likely to overengineer (relative to competitors' products) in its NPD efforts. A good understanding of competitive benchmarks is also likely to enable firms to achieve appropriate new product concepts quicker and to test-market new product prototypes more quickly and efficiently (Voss, Ahlstrom, and Blackmon 1997). Therefore, competitive intelligence and competitor knowledge may enable highly competitor-oriented firms to deploy NPD resources in ways that are more efficient than the industry average. 
Thus, I argue that competitor orientation is positively related to NPD speed and resource efficiency.

\section{$H_{1 b}$ : A firm's competitor orientation is positively associated with its NPD efficiency.}

The link between interdepartmental coordination and NPD efficiency. Interfunctional coordination is the coordinated use of company resources across departmental and functional boundaries in creating superior value for target customers (Narver and Slater 1990). In an NPD context, interfunctional coordination requires NPD teams to coordinate with many other functional area or departments (Lukas and Ferrell 2000; Menon and Lukas 2004).

Many previous studies indicate that coordination of NPD activities among employees and functional areas is associated with faster NPD (Gupta, Raj, and Wilemon 1986; Kessler and Chakrabarti 1996; Menon and Lukas 2004; Olson, Walker, and Ruekert 1995; Smith and Reinertsen 1991). Interdepartmental coordination requires the involvement of each function in order to serve customers' needs, such as marketing, sales, manufacturing, R\&D, finance, and accounting (Narver and Slater 1990). This kind of cross-functional involvement may significantly reduce NPD task-related errors and lead to early detection of mistakes (Kessler

and Chakrabarti 1996; Menon and Lukas 2004), thereby reducing the number of new product redesigns and respecifications and enhancing NPD efficiency by saving NPD time and expenditures (Im, Nakata, Park, and Ha 2003).

Interfunctional coordination also encourages each function to freely communicate information about its various customer experiences and the internal constraints within which new products will have to be developed and marketed (Narver and Slater 1990). The 
openness in communication and sharing information with different functions not only may enable every function to better understand other functions' time lines and budget plans (Im et al. 2003) but also may enhance problem-solving capabilities (Han, Kim, and Srivastava 1998) by providing a shared understanding for cooperation. Such shared understanding also reduces the occurrence and impact of strategy implementation barriers, further increasing relative NPD speed and resource utilization efficiency (e.g., Ruekert and Walker 1987). Furthermore, sharing resources with other functions in the interfunctional-coordinated firms (Narver and Slater 1990) may directly reduce duplicated budgets and any resource wasting, which is positively related to NPD efficiency. Thus, I suggest that

\section{$H_{1 c}$ : A firm's interdepartmental coordination is positively associated with its NPD efficiency.}

The link between customer orientation and NPD creativity. Customer-oriented firms make

efforts to understand customer needs and wants and systematically and frequently measure customer satisfaction (Narver and Slater 1990). Controversial arguments about the relationship between customer orientation and new product creativity exist in the literature. On the one hand, some scholars posit that input from customers will result in less novel ideas than are possible through technology- or engineering-driven innovation (e.g., Bennett and Cooper 1981). This argument posits that customers are often resistant to the idea of change, limited in their ability to provide creative input into the NPD process, and even unreliable in predicting which new product ideas ultimately will be embraced (Veryzer 1998; Voss and Voss 2000). Being customer focused can therefore lead to inertia in NPD (Christensen and Bower 1996). This viewpoint has some empirical support in the literature. For example, Im 
and Workman (2004) show that a customer orientation has a negative effect on new product novelty.

Meanwhile, other scholars believe that a customer orientation is more likely to provide innovative ideas (e.g., Im et al. 2003). This body of literature suggests that new product ideas can come from lead users' insights and suggestions (Brown and Eisenhardt 1995; von Hippel 1986). Traditional idea-generation techniques based on customer input usually collect information from a random or typical set of customers. A lead-user approach collects information about both needs and solutions from users at the leading edges of the target market as well as from users in other markets that face similar, but more extreme, problems. This approach assumes that lead users experience needs for a given innovation earlier than the majority of the target market. Lead users are also motivated to innovate, because they expect attractive innovation-related benefits from a solution to their needs (Lilien, Morrison, Searls, Sonnack, and von Hippel 2002). Compared with representative target-market users, lead users live in the future. Therefore, firms that see NPD through lead users' eyes are less likely to be myopically anchored on existing products in their NPD efforts (Slater and Narver 1998).

Intuition suggests that the better you understand your customers, the more likely you are to be able to identify lead users. Exposing new product teams to customers' needs and problems can motivate members to strive for more innovative solutions (Kanter 1989; Sethi, Smith, and Park 2001). Furthermore, if highly customer-oriented firms have low levels of competency traps, superior customer understanding should enable them to make any novel new product ideas meaningful to their target customers. Therefore, firms with a strong customer orientation will be more creative in their NPD and better able to market their new 
products such that customers will recognize and value their novelty. Therefore, I still argue that, absent competency traps,

\section{$\mathrm{H}_{2 \mathrm{a}}$ : A firm's customer orientation is positively associated with its NPD creativity.}

The link between competitor orientation and NPD creativity. Some researchers argue that a competitor focus may draw a firm's attention to the issue of relative cost efficiencies (Gatignon and Xuereb 1997), which may tempt a firm simply to adopt competitors' ideas and technology (Lukas and Ferrell 2000). However, if a firm does not exhibit competency traps, a highly competitor-oriented firm, with its superior knowledge of competitors, will have a better understanding of the benchmark products available to target customers as well as a better prediction of what competitors' future products will look like and competitors' likely product responses to the firm's new product launches. Such competitor knowledge may enable the firm make better decisions regarding what their new product needs to be different from (in terms of competitors' products), and how a product could deliver benefits to customers in ways that would be the most difficult for rivals to emulate. Knowing what competitors are and are likely to be doing, especially in terms of their strength and weaknesses, will therefore enable a firm to better understand what kind of NPD might be more novel and meaningful than that of their competitors in the market. Such competitororiented firms are highly likely to create new products that are differentiated from those of their competitors (Im and Workman 2004).

The objective of competitor-centered methods is to keep pace with or stay ahead of the rest of the field (Han, Kim, and Srivastava 1998). Therefore, such a competitive focus 
may provide firms with a motivation to search for novel new product ideas and facilitate new product innovation. Furthermore, from an evolutionary economics perspective, Dickson (1992) and Vorhies and Morgan (2005) argue that even though firms with a strong competitor orientation may be attempting to benchmark competitors' products and processes to engage in imitative learning, capability interdependence and the impact of different organizational contexts between a benchmarking firm and a competitor benchmark firm lead imitative learning attempts to result in novel learning outcomes for the benchmarking firm. This provides the capability basis for developing novel new products (Vorhies and Morgan 2005). Therefore, I suggest that, absent competency traps,

\section{$H_{2 b}$ : A firm's competitor orientation is positively associated with its NPD creativity.}

The link between interdepartmental coordination and NPD creativity. Interdepartmental coordination encourages cooperation and involvement from different functional areas and departments in order to create customer value (Narver and Slater 1990). The NPD literature suggests that different functions and departments that may be engaged in NPD have different sources of knowledge and different types of expertise, and often develop different "thoughtworlds" (Dougherty 1992). Such heterogeneity of viewpoints may increase the possibility discovering novel linkages and stimulate creativity of problem solving in NPD process (Im et al. 2003; Milliken and Martins 1996; Sethi, Smith, and Park 2001) . Therefore, absent competence traps, when different departments successfully coordinate these different knowledge bases and perspectives to create NPD process, the potential for novelty results from combining different areas of knowledge to create new knowledge. 
In addition, groups from different backgrounds and perspectives are more likely to engage in devil's advocacy and dialectical exchanges as they are forced to work together and to compromise and come up with agreements during the NPD process (e.g., Sethi, Smith, and Park 2001). This is likely to ensure that novel insights brought into the NPD process are also meaningful enough to persuade all areas involved of the likelihood of NPD success. Under such conditions, it is less likely that resultant new products are novel, because of the different perspectives brought to bear by different functional areas and departments, but are not meaningful to customers. Hence, I argue that interdepartmental coordination is associated with NPD creativity:

\section{$\mathrm{H}_{2 \mathrm{c}}$ : A firm's interdepartmental coordination is positively associated with its NPD creativity.}

\subsubsection{The Negative Side of Market Orientation As a Capability}

As capability-rigidity theory notes, it is also possible that MO as a capability may lead to rigidity, which this study refers to as competency traps. When strategic processes become routinized, commitment to established practices increases rigidity in behavior patterns and decreases both the volume and diversity of information processed (Fredrickson and Iaquinto 1989; Tushman and Romanelli 1985). This study argues that when a firm develops processes to facilitate its customer orientation, competitor orientation, and interfunctional coordination ( $\mathrm{Li}$ and Calantone 1998; Narver and Slater 1990), these processes may be negatively related to creative and radical new product innovation. Atuahene-Gima's (1996) study demonstrates that MO has a significant effect on product newness to customers but does not have a significant effect on product newness to the firm. 
A recent study by Zhou, Yim, and Tse (2005) also shows that MO facilitates innovations that use advanced technology and offer greater benefits to mainstream customers, but it inhibits innovations that target emerging market segments (e.g., lead users). These findings suggest that MO fosters incremental innovation, but at the same time it inhibits radical innovation.

Lukas and Ferrell (2000) argue that the three dimensions of MO should have different impacts on product innovation. Their findings show that (1) customer orientation increases the introduction of new-to-the-world products and reduces the launching of me-too products, (2) competitor orientation increases the introduction of me-too products and reduces the launching of line extensions and new-to-the-world products, and (3) interfunctional coordination increases the launching of line extensions and reduces the introduction of metoo products.

Drawing on the literature, $\mathrm{H}_{2 \mathrm{a}}-\mathrm{H}_{2 \mathrm{c}}$ also demonstrate that controversial arguments about the relationship among the three dimensions of $\mathrm{MO}$ and new product creativity exist in the literature. However, little insight is provided from available studies on how and why some dimensions of MO are associated with radical innovation and others are not. It is important for researchers and managers to understand the underlying rationale and processes of how organizational capabilities can lead to rigidity and inhibit innovation. In the following section, I attempt to map the processes of how the three dimensions of MO lead to competency traps.

The link between customer orientation and vision trap. According to section 2.3.5, a vision trap is a strong, self-perpetuating, cognitive inertia that leads firms to discount weak signals in the environment, where those signals threaten the source of a firm's confidence in its 
ability and actions. Three streams of literature provide a reason to expect a positive relationship between customer orientation and the degree to which a firm exhibits a vision trap.

The first stream proposes that persistency in customers' preferences can lead to inertia among customers that is internalized by customer-oriented firms. Most firms' existing customers are not, by definition, lead users. They often have strong preferences and may not value or seek new radically new or different features in a firm's new product offerings (Adner 2002; Im and Workman 2004). Close links with existing customers may therefore encourage a firm's NPD efforts to fine-tune its offering to its customers and commit the firm to its current customers only (Danneels 2003). Therefore, inertia among customers may lead firms that are close to their customers to have a limited vision with regard to their NPD (Christensen, Suarez, and Utterback 1999; Gatignon, Tushman, Smith, and Anderson 2002). This may explain why radical and innovative product ideas are most often marketed to totally new customer segments (Berthon, Hulbert, and Pitt 2004). If firms' resources are allocated to programs serving powerful, large, existing customers, firms may fail to lead in serving emerging customer segments, which may become mainstream over time (Christensen and Bower 1996). This stream of research therefore suggests that firms should ignore their existing customers (Chandy, Prabhu, and Antia 2003; Gatignon and Xuereb 1997; Hamel and Prahalad 1994) in order to resist NPD inertia. From this perspective, looser links with customers help a firm maintain its independence, its distinctiveness, and its selfdetermination (Danneels 2003; Orton and Weick 1990), which fosters its vision with respect to NPD. 
A second stream of literature criticizes the credibility of consumers' opinions as a source of new product ideas, even under the assumption that consumers' preference do change over time. Christensen and Bower (1996) argue that listening too carefully to customers will restrict firms' NPD vision to the familiar. Consumers are not perfectly informed about the latest market trends (Lukas and Ferrell 2000). They may not know enough about what new technologies are, or those that may become available, and they therefore lack foresight (Hamel and Prahalad 1994). They may not even be able to describe their requirements for a product that opens up entirely new markets and applications, limiting the innovation-driving benefits of the "voice of the customer" (O'Connor 1998). This stream in the literature therefore suggests that firms that are close to their customers and focus on customers in their NPD are less likely to acquire radical ideas and trigger creative NPD breakthroughs. Such firms are therefore more likely to have a constrained vision toward NPD.

The third stream of literature suggests that even if customers are not inert and possess foresight, the types of customers that make up the base of a customer-oriented firm may not change or vary greatly, making it difficult for a customer-oriented firm to hear very different and new voices. According to exit-voice theory (Hirschman 1970), when people are dissatisfied in relationships, they may engage in a number of behaviors including exit, voice, and loyalty. Customer dissatisfaction may come from a variety of causes, including customer preferences toward certain types of products and a desire for variety (Fornell and Wernerfelt 1987). Customer orientation leads to high customer satisfaction and increased customer loyalty (Jaworski and Kohli 1993, Narver and Slater 1990). Dissatisfied customers may voice their complaints or exit from the firm and switch to a competitor supplier (Fornell, Johnson, 
Anderson, Cha, and Bryant 1996). As a result, in a customer-oriented firm, the needs, requirements, and preferences of its customers may become more homogenous over timeeven if the firm operates in a relatively dynamic marketplace with heterogeneous customers across the marketplace. Therefore, the more a firm focuses on understanding and serving its existing customers, the less it may be able to envision things beyond the relatively narrow constraints of its current customers.

Therefore, I propose that

\section{$\mathrm{H}_{3 \mathrm{a}}$ : The higher a firm's customer orientation, the higher is the level of its vision trap.}

The link between customer orientation and technology trap. According to section 2.3.5, a firm in a technology trap tends to employ familiar and mature technologies in order to obtain legitimacy and operating efficiencies.

The literature suggests that customer orientation is negatively related to technological innovation. Technology is a powerful engine of economic progress (John, Weiss, and Dutta 1999). Technological knowledge accumulates as a function of technological experience, and radical new technologies incorporate substantially different and new knowledge (Nerkar and Roberts 2004). This type of knowledge can be sufficiently complex that it is difficult for competitors to imitate (Chandy and Tellis 1998; Dutta, Narasimhan, and Rajiv 1999; Wuyts, Dutta, and Stremersch 2004). However, because customers may have little professional knowledge about advanced technology, they may not be a good source of knowledge concerning the desirability of product benefits that may be available through the use of a new 
technology. It is therefore unlikely that customers can provide much constructive input concerning new technology selections for NPD. Even if a firm provides customers with technology options and lets customers make technology decisions, it is possible that customers may reject more advanced technology because they may be uncomfortable with the complexity of new functions. Since most customers are by definition not lead users, it is less likely that existing consumers will understand the complexity of radical technology and see the world through technological possibilities or that they will know enough about leading-edge technologies (Christensen and Bower 1996; Hamel and Prahalad 1994; Lukas and Ferrell 2000; Slater and Narver 2000). Therefore, listening to customers leads firms to focus on existing technologies and minor modifications to existing technologies.

In an environment of scarce resources, localized learning from existing customers is likely to be at the expense of learning from prospective customers. Existing customers may often have strong preferences for existing technology, and they may not value new, unfamiliar technology even if the new technology proves to make further development (Adner 2002; Im and Workman 2004). Customers with similar needs and requirements may be drawn to the same supplier, further reducing the variety encountered by the customer oriented firm in its NPD search efforts. Exit-voice theory suggests that this is likely to be exacerbated over time by increased switching behavior among customers of a firm that have different needs and requirements from those of a firm's mainstream customer base and that the firm may not meet as well (Hirschman 1970). A high customer orientation may therefore lead firms only to pursue new technologies that address the needs of their current customers and lock firms into existing mature and familiar technology (Adner 2002; Christensen and Bower 1996). A firm's choice of customer may therefore constrain its decisions concerning 
technology. Under such conditions, a customer orientation may be associated with firms that higher levels of technology traps. Therefore, I suggest the following:

\section{$H_{3 b}$ : The higher a firm's customer orientation, the higher is the level of its technology trap.}

The link between customer orientation and routinization trap. As described in section 2.3.5, a routinization trap refers to a situation in which firms tend to follow formalized and standardized processes, procedures, or routines for NPD.

Because customers may have relatively stable preferences, customer-oriented firms have little incentive to experiment with and change NPD routines. In addition, the literature suggests that customer-oriented firms have higher levels of customer satisfaction (e.g., Day 1994; Jaworski and Kohli 1993). Given that customer satisfaction is a key objective of customer-oriented firms, firms that are highly customer oriented and have high levels of customer satisfaction are less likely to seek to "fix what is not broken" in the NPD process. More likely, such firms will reinforce what may be a contributor to their success in satisfying customers by seeking to routinize their NPD procedures to minimize the likelihood of their working less well in future efforts to develop products that satisfy customer needs. Therefore, a customer orientation may lead firms to exhibit higher levels of routinization traps.

In addition, economic theory suggests that customers tend to seek new products with high utility (i.e., a relatively low price within a reasonable quality range) (e.g., Armstrong and Collopy 1996). In making trade-offs between cost and innovation in NPD, highly customer-oriented firms may therefore overweigh cost as compared with novelty. Adoption

of radical new ideas requires new and flexible procedures, which are difficult, costly, and 
risky (Hannan and Freeman 1977; Nelson and Winter 1982). Meanwhile, formalized NPD procedures carry out the repeated tasks of manufacturing and distributing large volumes of the products efficiently, and firms in price-sensitive and competitive markets are therefore likely to have an incentive to routinize rather than to use more-flexible NPD procedures (Hannan and Freeman 1977; Henderson and Clark 1990; Nelson and Winter 1982). Thus, a customer orientation may lead to a vested interest in the current NPD routines (Staw 1980).

Furthermore, exit-voice theory (Hirschman 1970) also suggests a negative consequence of customer orientation on firms' routinization behaviors. According to exitvoice theory, the exit of dissatisfied customers with needs and requirements that differ from those of the mainstream customer base may lead customer-oriented firms to have less variety in their customer population. This may be exacerbated over time by positive word-of-mouth recommendations from satisfied customers to prospective customers that may have similar needs. The resulting stability and lack of variety in a firm's customer population is less likely to create rapid changes in their needs, requirements, and preferences for new products. Therefore, the NPD processes required to serve customer needs are less likely to require significant and frequent changes in a highly customer-oriented firm.

\section{$H_{3 c}$ : The higher a firm's customer orientation, the higher is the level of its routinization trap.}

The link between competitor orientation and vision trap. Competitor orientation emphasizes knowledge search about competitors (Katila 2002). Although some literature argues that market- and learning-oriented small- and medium-sized enterprises facing strong competition tend to be more innovative (Sakavou, Baltas, and Lioukas 2004), the evidence linking 
competitor orientation with innovation is inconclusive. For example, Katila (2002) finds that firms that respond quickly to and build on their competitors' actions, may introduce more products, but that these new product introductions are often based on imitation and are often not unique.

The literature indicates that a focus on competitors can make managers think more about "beating the competitors" rather than "doing the best for my firm" (Armstrong and Collopy 1996). Social comparison theory (Suls 1977) suggests that when the information is available, people often judge their performance in comparison with that of others. In a highly competitor-oriented firm, providing managers with information concerning competitors may therefore lead firms to compare and contrast their products and processes with those of competitors. This type of benchmarking behavior is an imitative learning process (Voss, Ahlstrom, and Blackmon 1997) that constrains a firm's viewpoints and may limit a firm into local idea searches and block distant exploration in organizational learning. Thus, I argue the following:

\section{$H_{4 a}$ : The higher a firm's competitor orientation, the higher is the level of its vision trap.}

The link between competitor orientation and technology trap. A competitor focus should keep firms abreast of emergent competitive technologies or even promote a proactive engagement in developing one to "beat" rivals. Highly competitor-oriented firms therefore also often have a strong technological orientation (D’Aunno, Succi, and Alexander 2000). However, a decision to select an advanced technology that may be totally new to the market and the industry requires going against industry norms. According to institutional theory, 
firms tend to copy one another and converge toward competitive norms because of three types of pressures: (1) coercive pressures from legal mandates or influence from organizations they are dependent upon, (2) mimetic pressures to copy successful forms that arise during high uncertainty, and (3) normative pressures to homogeneity that arise from the similar attitudes and approaches of professional groups and associations brought into the firm through hiring practices (DiMaggio and Powell 1991; Meyer and Rowan 1977).

In the institutional environment, information about competitors' technology may therefore lead firms to mimic their competitors, adopt competitors' technology, and engage in refining the current similar technology rather than searching for and adopting leading-edge technology (Lukas and Ferrell 2000; Zahra, Nash, and Bickford 1995), because imitation may provide the legitimacy and certainty of the technology to the firms. In each industry, there are certain types of technologies that exist as a form of legitimacy or norm (e.g., Duguet and MacGarvie 2005; Wright 2000). A competitor-oriented firm may adhere to the established technology in order to obtain the legitimacy, because a competitor focus binds the firm to a local technology search rather than to a more widespread radical technology search in its organizational learning efforts.

\section{$H_{4 b}$ : The higher a firm's competitor orientation, the higher is the level of its technology trap.}

The link between competitor orientation and routinization trap. There are three reasons to expect that a competitor orientation may be positively associated with routinization traps as suggested in the literature. First, the availability of intelligence regarding competitors often leads firms to engage in competitive benchmarking of products, processes, and performance 
(Vorhies and Morgan 2005). In order to be competitive in terms of the price of new products and the cost of NPD, competitor-oriented firms are therefore likely to emphasize the efficient deployment of resources in their NPD efforts. In this situation, standardized routines, rather than constant and radical changes in NPD, may be preferred, because standardized routines require fewer inputs, enhance the benefits of experiential learning, and thereby help firms increase efficiency and reduce costs associated with their NPD (e.g., Clark, Amundson, and Cardy 2002).

Second, in focusing organizational learning search on competitors, firms often seek to imitate superior NPD routines from high-performing competitors. However, attempts at such imitative learning often fail, even within a single firm, when knowledge of the performance of a process is presumably greater than what a firm seeks to learn from a competitor (Szulanski 1996). The sticky nature of the information about competitor routines, procedures, and processes makes it very difficult and very costly to acquire and transfer that information (von Hippel 1994, 1998). Even if a competitor-oriented firm gains insight into a competitor's NPD processes, the difficulties in transforming the firm's own processes mean that most such attempts at imitative learning fail (Vorhies and Morgan 2005). As a result, existing NPD routines in competitor-oriented firms can become more inert.

Third, a strong competitor focus may itself be a source of legitimacy in an industry. This may be seen in the strong competitor orientations advocated by managers in particular industries, such as the semiconductor industry (Grove 1990). If competitors in an industry focus on one another, few radically new capabilities may be developed, thus reducing the likelihood of significant changes in NPD processes with an industry. Furthermore, in the institutional environment, certain types of NPD routines may serve as a source of legitimacy 
or form ingredients in industry recipes as to how tasks should be accomplished (e.g., Duguet and MacGarvie 2005; Wright 2000). In order to be competitive, a competitor-oriented firm may therefore tend to acquire legitimacy in its NPD routines and conduct only local searches in its organizational learning for process improvement. In this situation, incremental changes in NPD processes may be preferred to dramatic and frequent changes in NPD processes. Therefore, high competitor orientation may increase the possibility of falling into a routinization trap.

\section{$H_{4 c}$ : The higher a firm's competitor orientation, the higher is the level of its routinization trap.}

The link between interfunctional coordination and vision trap. The literature provides two reasons to believe that interfunctional coordination may lead to vision traps in firms' NPD efforts. First, the literature suggests that cognitive conflict is common in cross-functional teams, and such conflicts may undermine the production of novelty (Joshi and Sharma 2004). As a result of different languages and vocabularies in different functional areas (Dougherty 1992; Lovelace, Shapiro, and Weingart 2001), misunderstandings and disagreements often occur in cross-functional teams. Resultant difficulties in reaching agreements and finding integrative solutions for conflicts (Lovelace, Shapiro, and Weingart 2001) may lead teams to resort to simplifying heuristics or algorithmic problem solving (Andrews and Smith 1996; Im et al. 2003). As a result, conformity and groupthink may emerge as ways to reduce coordination costs and conflicts in groups of individuals from different functional areas and departments. Janis (1982) defines groupthink as the propensity of groups to respond to interpersonal pressure in such a manner that group members' strivings for unanimity override 
their motivation to analyze alternative courses of action realistically (see also Miranda and Saunders 1995).

Conformity and groupthink have been often observed in firms with high levels of interfunctional coordinated that encourage employees with different perspectives to work together with a focus on a single task (NPD), with a single superordinate goal (serving customers), and under time pressure (as is most often the case in NPD projects) (Adams, Day, and Dougherty 1998; Sarin and McDermott 2003). Although such groupthink minimizes conflicts, it may encourage free riding and stifle innovative ideas (Jehn and Mannix 2001). This may constrain firms' visions for NPD and reduce the questioning of NPD assumptions, such as the continued appropriateness of process and routines that have been successful in the past.

Second, in contrast to the other two elements of MO, interfunctional coordination is internally focused on relationships and processes within the firm (e.g., Shapiro 1988). The literature suggests that, ceteris paribus, a strong focus on interfunctional coordination is therefore more likely to lead a firm to compare its NPD processes and effectiveness with internal objectives and past performance than with external benchmarks (Greve 2003). This may constrain a firm's organizational learning search in NPD to the local environment inside the firm. Given resource scarcity for organizational learning (Vorhies and Morgan 2005), this is likely to limit more distant external information search and may prevent the firm from having a more open and questioning vision of its NPD capabilities.

Thus, I argue the following:

\section{$H_{5 \mathrm{a}}$ : The higher a firm's interdepartmental coordination, the higher is the level of its vision trap.}


The link between interdepartmental coordination and technology trap. Two areas highlighted in the literature indicate a potential relationship between interdepartmental coordination and technology traps. First, while the literature indicates that personnel with diverse backgrounds may potentially bring fresh perspectives to NPD (Beckman and Haunschild 2002), they may also cause conflicts among different functional areas. Different functions may have different ideas and suggestions on how to conduct novel and meaningful NPD, each of which may involve certain degrees of risk (Wind and Mahajan 1997). The increased difficulties associated with reaching agreements across different departments and different "thoughtworlds" leads firms to seek a way to minimize interdepartmental conflicts (Janis 1982; Miranda and Saunders 1995). Reliance on proven existing and established technologies in NPD is one way to aid coordination among different functions and provides a safe way to reduce uncertainty and minimize the political interfunctional arguments (Tyre and Hauptman 1992). Therefore, the pressure to make agreements and coordinate among different functions may lead firms to prefer to adopt and maintain existing and familiar technologies rather than leading-edge technologies in their NPD efforts (Argyris 1982; Carmel 1995; Crawford 1992; Lukas and Ferrell 2000).

Second, the management and marketing literature also suggest that the execution of strategies that requires the acquisition and deployment of new-to-the-firm resources is more difficult to achieve than those that are "tried-and-tested" within the firm (Moorman and Miner 1997; Ruekert and Walker 1987). This literature also indicates that a lack of effective interfunctional coordination is a key problem that undermines strategy execution (Jaworski and Kohli 1993; Walker and Ruekert 1987). To the extent that firms with a focus on 
interdepartmental coordination are seeking to smooth strategy implementation, they are therefore less likely to continually seek to incorporate new technologies in their NPD strategies, since this would increase likely strategy implementation problems. Therefore, this literature suggests that negotiation, consensus, compromise, and a stronger focus on implantation "realities" will increase the perceived coordination difficulties from any radical change and will lead firms to prefer incremental changes in technology in an NPD context (e.g., Ruekert and Walker 1987). Thus, I suggest the following:

\section{$H_{5 b}$ : The higher a firm's interdepartmental coordination, the higher is the level of its technology trap.}

The link between interfunctional coordination and routinization trap. Routines refer to processes or procedures for NPD. Organizational routines are tacit procedures that become embedded in NPD practice and serve to give employees a standardized, practical means to accomplish required tasks. Routinization becomes a method of getting things done, a sharing between organizational members of learning as a common understanding so as to exploit what is necessary to achieve the ends desired (Fiol 1994). Routines go beyond written manuals to include tacit procedures as well as explicit processes (Clark, Amundson, and Cardy 2002). These routines provide a map for people with different skills and knowledge across different areas to work together to achieve a common objective. The literature suggests two reasons to expect a positive relationship between interfunctional coordination and routinization traps.

First, firms with a strong interdepartmental orientation focus on maintaining strong coordination mechanisms (Maltz and Kohli 2000). Since the NPD process is a key 
coordinating process within most firms (Menon and Lukas 2004), firms seeking to maintain coordination will have less incentive to change their NPD routines. Moreover, as previously discussed interdepartmental orientation emphasizes local NPD learning within the firm and is less conducive to the conduct of extensive distant or external searches for potentially novel new NPD routines.

Second, the structure of interfunctional coordination may shift firms' focus from the external environment to internal coordination. According to Tushman and Romanelli (1985), internal requirements for coordinated activities and flows may lead to increased structural elaboration and social complexity. Such interdependent structural and social linkages in coordinated activities dispose individuals in the group against any radical change (in the routines) and increase individual and group commitments to the current status and routines (Houston et al. 2001; Miller and Friesen 1980). Therefore, high interdepartmental coordination is likely to increase cognitive inertia toward current new product routines and invites incremental modifications rather than radical changes in new product processes and procedures.

For these reasons I expect the following:

\section{$H_{5 c}$ : The higher a firm's interdepartmental orientation, the higher is the level of its routinization trap.}

\subsubsection{Competency Traps}

Nakata and Sivakumar (1996) define NPD as "the process of conceiving and creating a new product and the outcomes of that process." The objective of NPD is to combine available resources for creating value offerings that match the needs of the external 
environment. Strong organizational learning capabilities can lead to enhanced NPP and lead a firm to be highly innovative (Cohen and Levinthal 1990).

The link between vision trap and NPD efficiency. Firms engage in exploration and/or exploitation of knowledge through organizational learning to improve their ability to effectively and efficiently perform required tasks (e.g., Slater and Narver 1995). A vision trap represents a cognitive bias toward current NPD procedures that have already demonstrated favorable outcomes. Vision-trapped firms tend to believe that habitual activity or experiential learning (i.e., exploitation) is a more efficient way of solving NPD problems than exploration (Luchins and Luchins 1970). Firms immediately benefit from this kind of exploitation learning by having certain speed, proximity, and clarity of outcome (March 1991). A low level of vision trap indicates less cognitive inertia in the existing NPD process and a strong preference toward experimentation with new NPD procedures. However, the returns from this kind of exploration learning returns are uncertain, distant, and often negative. Low speed and high costs of experimentation are common features of exploration learning (March 1991). Thus, organizational learning theory suggests that

\section{$H_{6 a}$ : The level of vision trap in a firm's NPD process is positively associated with its NPD efficiency.}

The link between technology trap and NPD efficiency. Technology-trapped firms tend to rely on the legitimacy of familiar and current existing mature technologies. Familiar technology requires little new or additional learning in the firm's NPD process (Ahuja and Lampert 2001). Firms in technology traps become specialized in a familiar technology (Levinthal and March 1993; Levitt and March 1988). The experiential learning from familiar technology 
may shorten the time taken in NPD and increases the potential discovery of ways to use resources more productively in the NPD process. Mature technologies are also relatively well known in the industry (Ahuja and Lampert 2001). The legitimacy of mature technologies may also shorten NPD cycle times by increasing the speed of acceptance of new products among customers and channel intermediaries (Ahuja and Lampert 2001; Levinthal and March 1993; Levitt and March 1988). Products incorporating mature technology may therefore also enable a firm to expend relatively fewer resources convincing customers of their legitimacy (Ahuja and Lampert 2001). The relative reliability of mature technologies may also reduce new product failures during the NPD process, further saving time and other resources.

In contrast, firms with a low level of technology traps have to spend more time on learning new technologies, and they also expend more effort and deploy more resources to educate their customers on new technologies. Furthermore, many emerging technologies may make fundamental breakthroughs and achieve eventual success only after they have gone through a number of failures (Ahuja and Lampert 2001). New emerging technologies are therefore likely to require more time and greater resources than mature and familiar technology in NPD. Therefore, firms with a low level of technology traps may not be as efficient as firms with a high level of technology traps.

\section{$H_{6 b}$ : The level of technology traps in a firm's NPD process is positively associated with its NPD efficiency.}

The link between routinization trap and NPD efficiency. Firms in routinization traps tend to follow formalized/standardized rather than flexible/new NPD processes, procedures, or 
routines. Formalized and standardized procedures may facilitate experiential learning by simplifying and repeating the same routines over time (Clark, Amundson, and Cardy 2002). This kind of facilitated learning may shorten the NPD process and enable the firm to use its NPD resources very productively (Levinthal and March 1993). In contrast, firms with low level of routinization traps may use more flexible NPD procedures and tend to experiment with new NPD procedures (Arthur 1984; Levitt and March 1988). It takes time for firms to learn new procedures and make adjustment to different NPD procedures (DiMaggio and Powell 1991). Experimenting with new NPD procedures can be costly and may require that firms maintain underutilized resources to enable a switch in NPD procedures when the results of experimental learning indicate that a new NPD process may be beneficial (e.g., Dobrev, Kim, and Carroll 2003). Thus,

\section{$H_{6 c}$ : The level of routinization traps in a firm's NPD process is positively associated with its NPD efficiency.}

The link between vision trap and new product creativity. As noted in section 2.3.5, vision traps occur when organizations have a cognitive bias toward current NPD procedures and tend to deny the need to change their NPD processes. A higher level of vision trap indicates overconfidence in a firm's current NPD process. Such confidence may create a strong, selfperpetuating cognition, and lead firms stay within a comfort zone in their NPD processes that they believe have been successful in the past (Levinthal and March 1993; Levitt and March 1988). Firms with high levels of vision trap are less likely to search broadly, because they are satisfied with the performance of their existing NPD capabilities (e.g., Greve 2003; Miller 1990). Strong inertia in current NPD procedures therefore reduces their motivation to 
conduct intensive exploration learning and to search for greater creativity in their NPD efforts.

In contrast, a low level of vision trap indicates low cognitive inertia or bias in favor of the existing NPD processes. Firms with low cognitive inertia tend to look for opportunities and areas for improvement in their existing NPD processes and procedures. They are highly motivated to conduct distant exploration learning in order to develop more novel and meaningful new products than their existing products (Levinthal and March 1993; Levitt and March 1988). Therefore, firms with low levels of vision traps are more likely to seek and find creativity in their NPD efforts:

\section{$\mathrm{H}_{7 \mathrm{a}}$ : The level of vision traps in a firm's NPD process is negatively associated with its NPD creativity.}

The link between technology trap and new product creativity. Firms with higher levels of technology traps tend to rely on the legitimacy of familiar and current existing mature technologies. Although sticking with familiar and current existing mature technologies may require less time and effort in NPD, failure to incorporate new technologies may lead the firm to render its NPD capabilities obsolete over time (Afuah 2001). The nature of localized learning in NPD that draws on familiar and mature technologies may limit the possibilities for the development of creative new products. In addition, higher levels of technology traps are likely to be evident in firms that have a low technology orientation, which is often associated with a low R\&D orientation. Yet greater R\&D capabilities have been linked with more innovative NPD efforts (Cohen and Levinthal 1990). 
In contrast, lower levels of technology traps may be positively related to a high technological orientation. A technology-oriented firm tends to encourage employees to seek novel ideas and meaningful inventions (Zhou, Yim, and Tse 2005). Firms with a low level of technology traps are willing to incorporate early emerging technologies even though these new technologies may not be as efficient or may provide less certain returns (Levinthal and March 1993; Levitt and March 1988). However, the fresh perspective offered by new emerging technologies offers a greater likelihood of creativity in NPD. In order to be able to make fundamental breakthroughs later (Ahuja and Lampert 2001), firms with lower levels of technology traps are willing to trade legitimacy and efficiency benefits from mature or familiar technology for NPD creativity benefits that are potentially available from more recently developed and less-well-tested new technologies. Thus:

\section{$H_{7 b}$ : The level of technology traps in a firm's NPD process is negatively associated with its NPD creativity.}

The link between routinization trap and new product creativity. Firms with higher levels of routinization traps tend to follow formalized and standardized processes, procedures, or routines to develop new products. Formalized procedures are likely to produce routine solutions to problems, which discourages new-idea generation (Troy, Szymanski, and Varadarajan 2001). The inertia that often accompanies standardization of procedures may limit firms' NPD learning within a local domain. However, novel NPD ideas may require distant learning in order to obtain a very fresh perspective (Brockman and Morgan 2003; Cohen and Levinthal 1990). 
In contrast, firms with lower levels of routinization traps tend to use less formalized and standardized routines and as a result have more flexible NPD routines. In general, lowformalization and high-flexibility NPD routines permit openness and facilitate creative ideas (Damanpour 1991). Creativity in NPD often comes from greater risk taking and multiple experiments involving NPD procedures or processes (Wind and Mahajan 1997). It is intuitive that radical and creative new products are less likely to emerge from the same NPD procedure that produced a firm's existing products. Thus:

\section{$H_{7 \mathrm{c}}$ : The level of vision traps in a firm's NPD process is negatively associated with its NPD creativity.}

As elaborated above, MO as a capability may have a "dark-side" effect— the development of competence traps. In order to reduce the detrimental effects of competency traps, organizations may create double-loop learning systems by creating a complementary $\mathrm{EO}$ and by engaging in network learning. This dissertation proposes that EO and network learning are two important complementary assets to MO that may reduce both the level and the negative effects of competency traps in the NPD process.

\subsubsection{Entrepreneurial Orientation}

Entrepreneurial orientation concerns entrepreneurship behaviors at the firm level rather than at the individual level (Lee, Lee, and Pennings 2001). According to the literature reviewed in section 2.4.2, EO refers to a culture with high tolerance for risk, high innovation, and proactiveness (Covin and Slevin 1991; Lumpkin and Dess 1996; Lyon, Lumpkin, and Dess 2000; Richard et al. 2004). New product development teams may perceive higher psychological safety in their decision making in highly entrepreneurial-orientated firms than 
in low entrepreneurial-oriented firms, which may encourage them to search for novel new product ideas. Competency traps represent a tendency to maintain existing and familiar technologies and routines in NPD (Levinthal and March 1993). Firms with higher levels of competency traps tend to engage in excessive exploitation because the return of exploitation is more certain, quick, and precise than that of exploration (March 1991).

\section{The direct link between entrepreneurial orientation and vision trap}

In a direct way, an entrepreneurial culture that values innovativeness, risk taking, and proactiveness may change managers' perceptions of the risks involved in exploring the domain of the firm's NPD processes. According to Kirzner (1997), an entrepreneurial culture encourages a firm to discover new means-end relationships rather than to seek to optimize existing ones. Highly entrepreneurial-oriented firms are therefore more likely to proactively seek novel ideas for new products through experimental and creative NPD processes (e.g., Covin and Slevin 1991; Lumpkin and Dess 1996; Lyon, Lumpkin, and Dess 2000).

In contrast, a low EO may discourage the proactive risk taking and comfort with ambiguity and potential for failure that may be required to depart from existing NPD routines that are believed to have been successful in the past. Rather, a firm with a low EO is more likely to maintain less risky and more certain current NPD procedures or routines and to focus on the less ambiguous and more obvious benefits available from local exploitation learning in their NPD efforts. Therefore, a firm's EO may directly reduce vision traps by encouraging managers to focus on new opportunities and providing a strong motivation to move away from the firm's preexisting routines for developing new products.

Thus: 


\section{$H_{8 \mathrm{a}}$ : The higher a firm's EO, the lower is the level of its vision trap.}

The direct link between entrepreneurial orientation and technology trap. The innovativeness dimension of EO emphasizes the ability to implement experimentation and to develop original approaches to problem solving (Covin and Slevin 1991; Lumpkin and Dess 1996; Lyon, Lumpkin, and Dess 2000). Highly entrepreneurial-oriented firms may therefore tend to avoid using mature and familiar technologies and instead are more likely to value new and emerging technologies for NPD activities. The risk-taking dimension of EO promotes more risky and less certain behaviors in the NPD process (Covin and Slevin 1991; Lumpkin and Dess 1996; Lyon, Lumpkin, and Dess 2000). High-risk goals are usually preferred in such firms (Covin and Slevin 1991; Lumpkin and Dess 1996; Lyon, Lumpkin, and Dess 2000). In a highly entrepreneurial-oriented firm, it is less likely for NPD teams to "play it safe" and stick with technologies they already know in the NPD process. Although adopting new emerging technologies in NPD may risk increased problems in customer acceptance and lower reliability, the behaviors valued in highly entrepreneurial-oriented firms may lead managers to perceive the risk of sticking with new and familiar technologies as greater than the risk of missing new opportunities that may be afforded by new emerging technologies (Adner 2002; Gatignon et al. 2002; Slater and Narver 2000). The proactiveness dimension of EO fosters a forward-looking perspective and values the creation of a first-mover advantage (Covin and Slevin 1991; Lumpkin and Dess 1996; Lyon, Lumpkin, and Dess 2000). A highly entrepreneurial-oriented firm is therefore more likely to encourage its NPD teams to incorporate very new technologies in its NPD process that rivals may not yet have adopted. 
In contrast, low entrepreneurial-oriented firms may not value innovation and experimentation approaches very much, and they may not prioritize new emerging technology ahead of mature and familiar technology (Adner 2002; Gatignon et al. 2002). Low risk taking in low entrepreneurial-oriented firms may discourage broad NPD technology search and encourage only local technology search in NPD (Nerkar and Roberts 2004). In addition, the reactive posture associated with low levels of EO may only motivate the firm to engage in imitative learning as a way of seeking legitimacy (Covin and Slevin 1991; Lumpkin and Dess 1996; Lyon, Lumpkin, and Dess 2000). Mature and familiar technology is therefore more likely to be preferred in NPD efforts rather than new emerging technology in low entrepreneurial-oriented firms.

Therefore:

\section{$\mathrm{H}_{8 \mathrm{~b}}$ : The higher a firm's EO, the lower is the level of its technology traps.}

The direct link between entrepreneurial orientation and routinization trap. Highly entrepreneurial-oriented firms highly value experimentation and original approaches to problem solving (Covin and Slevin 1991; Lumpkin and Dess 1996; Lyon, Lumpkin, and Dess 2000). Such cultures may therefore encourage managers to experiment with new and different NPD procedures and routines. Highly entrepreneurial-oriented firms do not like to play it safe (Covin and Slevin 1991; Lumpkin and Dess 1996; Lyon, Lumpkin, and Dess 2000). Maintaining preexisting fixed and formalized NPD procedures is therefore not consistent with the characteristics of entrepreneurially oriented firms. Rather, such firms prefer to take greater risks and conduct broader searches in their organizational learning that may result in more significant and radical changes to the firm's NPD routines. The proactive 
nature of highly entrepreneurial-oriented firms drives them to chase potential new opportunities in a changing market (Lumpkin and Dess 1996). This makes it less likely that such firms will protect and maintain the same standardized or formalized NPD procedures over time.

In contrast, low entrepreneurial-oriented firms may be much more concerned with avoiding risk in their NPD activities, and they are therefore less likely to recognize a need for change in NPD processes and procedures that may have been proved over time. Rather, fixed and formalized NPD procedures may be valued by low entrepreneurial-oriented firms. The culture of firms with a low EO is likely to encourage process inertia (Covin and Slevin 1991; Lumpkin and Dess 1996; Lyon, Lumpkin, and Dess 2000), making them slow to recognize a need to change their NPD processes and limiting changes that are adopted once a need to do so is recognized. Local NPD learning is likely to be more encouraged than broader NPD learning, which discourages experimentation and the exploration of new and different ways to accomplish NPD tasks (Nerkar and Roberts 2004).

Thus, I suggest the following:

\section{$H_{8 c}$ : The higher a firm's EO, the lower is the level of routinization traps in its NPD}

Entrepreneurial orientation, market orientation, and competency traps. According to Slater and Narver (1995), an MO within a firm may not encourage a sufficient willingness to take risks. A market-oriented firm may not be able to envision opportunities for radical new products in new markets, because it focuses primarily on the express needs of its existing customers (Christensen and Bower 1996; Lukas and Ferrell 2000; Slater and Narver 1995). 
Therefore, an MO may lead to competency traps. In the following section, I propose that EO plays a moderating role in the link between $\mathrm{MO}$ and competency traps. This suggests that in addition to its direct negative effect on competency traps, a firm's EO may also weaken the relationship between its $\mathrm{MO}$ and competency traps.

In this moderating role, EO is suggested as a complement to MO (Slater and Narver 1995). By providing a motivational force against inertia and rigidity, entrepreneurial cultures may weaken the tendency of market-oriented firms to have a narrow focus on existing customers, competitors, and cross-functional relationships that facilitate the development of competency traps in the NPD process.

The moderating role of entrepreneurial orientation in the link between market orientation and vision trap. In highly entrepreneurial-oriented firms, an MO is less likely to create vision traps. As argued in earlier hypotheses, MO may be associated with vision traps. $\mathrm{H}_{3 \mathrm{a}}$ argues that customer orientation may limit firms' vision because of customers' preference inertia, the credibility of customers as a source of new product ideas, and the stability of customer populations in customer-oriented firms. However, an entrepreneurial culture values risk taking and proactive postures (Covin and Slevin 1991; Lumpkin and Dess 1996; Lyon, Lumpkin, and Dess 2000). This may help customer-oriented firms to overcome the relatively limited vision available from an existing customer perspective when the firm searches for new product ideas. Firms will be less likely to limit their learning search in NPD to only their existing customers. They may be more likely to also approach different potential future customer populations and even chase feedback from their existing unhappy or unsatisfied customers. Thus, an entrepreneurial culture may give firms the motivation to engage in a 
more widespread search for customer feedback and to target new and different customer populations to break through the limited vision that may be created by customer orientation alone.

Similarly, as argued in $\mathrm{H}_{4 a}$, a competitor orientation may also limit firms' NPD vision by promoting imitative learning. However, an entrepreneurial culture emphasizes risk taking and the use of original approaches to problem solving (Covin and Slevin 1991; Lumpkin and Dess 1996; Lyon, Lumpkin, and Dess 2000). Such a culture may discourage competitororiented firms from simply imitating in their learning behaviors and encourage them to also experiment with new NPD approaches that are different from those employed by their competitors. Thus, EO may weaken the relationship between competitor orientation and vision traps.

According to $\mathrm{H}_{5 \mathrm{a}}$, interfunctional coordination may also limit firms' vision by fostering conformity, groupthink, and an internal orientation. However, an entrepreneurial culture values risk taking and proactive perspectives (Covin and Slevin 1991; Lumpkin and Dess 1996; Lyon, Lumpkin, and Dess 2000). The risk taking aspect of entrepreneurial orientation may help reduce the danger of prioritizing the minimization of conflict in interdepartmental communication that can lead to groupthink. Furthermore, it is also less likely that a firm with both a focus on interfunctional coordination and an EO will choose less challenging projects in order to avoid potential functional conflicts between departments and functions. The proactive characteristic of EO (Covin and Slevin 1991; Lumpkin and Dess 1996; Lyon, Lumpkin, and Dess 2000) may also help managers recognize and plan ways to deal with the potential coordination challenge if interfunctional teams work on very 
new, and therefore more uncertain and risky, NPD projects. Therefore, an entrepreneurial culture may weaken the link between interfunctional coordination and vision traps.

Therefore:

\section{$\mathrm{H}_{9 \mathrm{a}}$ : A firm's EO weakens the positive relationship between its MO and vision traps in its NPD process.}

The moderating role of entrepreneurial orientation in the link between market orientation and technology trap. In highly entrepreneurial-oriented firms, $\mathrm{MO}$ is also less likely to create technology traps. According to $\mathrm{H}_{3 \mathrm{~b}}$, customer orientation may lead to technology traps, because little professional knowledge about advanced technology makes customers a poor source of information in making NPD technology-selection decisions. In addition, existing customers' preferences for existing technologies may lead customer-oriented firms to resist moving away from existing familiar or mature technologies (Adner 2002; Im and Workman 2004). However, an entrepreneurial culture may weaken or even break these links. Entrepreneurially oriented firms seek to be innovative, risk taking, and proactive. Such firms may therefore be more likely to avoid making technology-selection decisions solely on the basis of inputs from their existing customers.

Similarly, as argued in $\mathrm{H}_{4 \mathrm{~b}}$, a competitor orientation may also lead to technology traps because a firm focused on competitors may often engage in mimetic technology learning and seek to adopt competitors' technologies (Lukas and Ferrell 2000; Zahra, Nash, and Bickford 1995). However, EO may weaken this link by encouraging managers in competitor-oriented firms to emphasize risk taking and the use of original approaches to problem solving (Covin and Slevin 1991; Lumpkin and Dess 1996; Lyon, Lumpkin, and Dess 2000). This may lead 
managers in competitor-oriented firms to resist industry norms, ignore legitimacy threats, and test riskier new technologies in their NPD projects. Simple imitation of competitors' technology may therefore be strongly discouraged in highly entrepreneurial-oriented firms.

According to $\mathrm{H}_{5 \mathrm{~b}}$, interfunctional coordination may also lead to technology traps because the pressure to seek agreements among interfunctional members makes interfunctionally coordinated firms stick with familiar or mature technologies with which each functional area is already familiar (Argyris 1982; Carmel 1995; Crawford 1992; Lukas and Ferrell 2000). However, the risk-taking and proactiveness characteristics of an entrepreneurial culture may weaken this link. Risk taking may help firms focused on interfunctional coordination discount the danger of coordination difficulties and conflicts and promote consideration of whether technology options can lead to radical NPD innovation in the technology-selection process. Proactiveness may also help managers in firms focused on interdepartmental coordination expect and be prepared for potential interfunctional conflict. Therefore, this forward-looking posture in entrepreneurial culture may weaken the link between interfunctional coordination and technology traps.

Therefore:

\section{$\mathrm{H}_{9 \mathrm{~b}}$ : A firm's EO weakens the positive relationship between its MO and technology traps in its NPD process.}

The moderating role of entrepreneurial orientation in the link between market orientation and routinization trap. In highly entrepreneurial-oriented firms, MO is also less likely to create routinization traps. According to $\mathrm{H}_{3 \mathrm{c}}$, customer orientation may lead to routinization trap as a result of existing customers' relatively stable preferences, trade-offs between cost 
and innovation, and relatively stable customer populations in customer-oriented firms. However, by encouraging the development of very fresh and creative new solutions in the NPD processes, an entrepreneurial culture may weaken or even break these links.

Furthermore, such a culture will promote the change in rather than the exploitation of existing processes. As a result, entrepreneurially oriented firms are much more willing to take risks and to seek to be innovative in their NPD procedures and routines (Covin and Slevin 1991; Lumpkin and Dess 1996; Lyon, Lumpkin, and Dess 2000).

Similarly, as argued in $\mathrm{H}_{4 c}$, a competitor orientation may also lead to routinization traps, because it leads managers to focus on cost and efficiency, imitative learning, and threats to legitimacy. However, the value placed on innovation, risk taking, and proactiveness may enable a firm with an entrepreneurial culture to weaken these links (Covin and Slevin 1991; Lumpkin and Dess 1996; Lyon, Lumpkin, and Dess 2000). An EO may discount or offset the cost/efficiency focus of competitor orientation, promote exploration over imitative learning in the NPD process, and encourage risk taking and the use of original approaches to problem solving in NPD (Covin and Slevin 1991; Lumpkin and Dess 1996; Lyon, Lumpkin, and Dess 2000). These perspectives may motivate competitor-oriented firms to go against industry norms, ignore legitimacy threats, and experiment with and employ different new NPD routines. Therefore, EO may weaken the relationship between competitor orientation and routinization traps.

According to $\mathrm{H}_{5 \mathrm{c}}$, a focus on interfunctional coordination may also lead to routinization traps because its internal orientation and concern for minimizing conflicts and promoting harmony among different functions may tempt the firm to stick with existing NPD routines (Maltz and Kohli 2000), which then become more formalized over time. However, 
by promoting innovation, risk taking, and proactiveness, EO may weaken these links (Covin and Slevin 1991; Lumpkin and Dess 1996; Lyon, Lumpkin, and Dess 2000).

Entrepreneurially oriented firms are more willing to take risks and experiment with different NPD routines and procedures in order to be unique and innovative (Covin and Slevin 1991; Lumpkin and Dess 1996; Lyon, Lumpkin, and Dess 2000). Their proactive attitude enables them to be prepared for potential functional conflicts and coordination difficulties in advance, which reduces the priority placed on avoiding interfunctional conflict. It is therefore less likely that entrepreneurially oriented firms employ the same standardized NPD processes over time.

For these reasons, I expect the following:

\section{$\mathrm{H}_{9 \mathrm{c}}$ : A firm's EO weakens the positive relationship between its MO and routinization traps in its NPD process.}

\subsubsection{Network Learning}

Network relationships are an important aspect of a firm's social capital that determine the firm's ability to create value and achieve economic goals (Tsai 2000). This dissertation defines network learning as the willingness to build strong relationships with parties in the broader environment outside of the firm, such as suppliers, distributors, consultants, universities, and government agencies. Strategic network learning provides a firm with access to a diversity of knowledge (Cohen and Levinthal 1990) that may stimulate the creation of new knowledge within the firm and foster innovation (Tsai 2001). An NPD team is more likely to formulate creative decisions if it has speedy access to timely information; diverse ideas; and critical instrumental, political, and emotional resources from the firm's 
external connections with diverse groups (Ancona and Caldwell 1992; Milliken and Martins 1996). Furthermore, network learning may also reduce innovation uncertainty through communication and information sharing (Kraatz 1998), which may further reduce the occurrence of competency traps.

The direct link between network learning and vision trap. In a direct way, network learning may increase firms' broad external learning. According to Slater and Narver (1995), the development of long-term, stable relationships (e.g., Glazer 1991; Miles and Snow 1992; Mohr and Spekman 1994; Ruekert, Walker, and Roering 1985) with "learning partners" can lead to information sharing that benefits both partners. Networks of interfirm relationships may provide channels for sharing valuable information, experience, knowledge, connections, and resources (Luo 2003). In this situation, diverse information from outside the firm and its immediate environment may reduce the possibility that firms are overconfident in their existing NPD processes. Rather, firms with strong network learning systems in place will have a strong orientation to the broader environment that keeps them updated with novel ideas and new perspectives in the NPD process.

In addition, broad network learning may empower the firm with a broader NPD vision, because the firm's conception of what is normal, legitimate, and superior extends beyond its own industry. The diverse sources of information, knowledge, and experience from network partners outside of the firm's own industry may give firms an opportunity to view more dissimilar alternatives and to be aware of very novel fresh perspectives (YliRenko, Autio, and Sapienza 2001), which should provide firms with a less constrained vision. Successful examples of dissimilar NPD activities in other industries provide a strong 
motivation to move away from current conventional NPD processes and to experiment different new NPD process.

Thus, I propose the following:

\section{$\mathrm{H}_{10 \mathrm{a}}$ : A firm's network learning is negatively associated with the level of vision traps in its NPD processes.}

The direct link between network learning and technology trap. There are two main reasons to expect that network learning reduces the occurrence of technology traps. First, when firms experience uncertainty about the likelihood of technical success and its associated costs, they may expand their networks in order to learn about new practices and technologies (Powell, Koput, and Smith-Doerr 1996). Because such network partners may have different operational resources (e.g., production facilities, technologies, and distribution channels) network learning increases a firm's ability to discover and access different new technologies (Luo 2003). Second, network learning helps firms to see different new technologies as legitimate and therefore acceptable to incorporate in NPD efforts. Through diversity in firms' networks, technical uncertainty is more likely to be controllable (Beckman, Haunschild, and Phillips 2004). Diverse networks with others (e.g., organizations in other industries, universities, technology labs, outside consultants, suppliers) can help firms maintain or regain legitimacy. These types of network relationships can signal to external constituents that technical uncertainty is being recognized and dealt with, which may reduce the propensity to select familiar and mature technologies in order to alleviate legitimacy concerns of customers and investors in technology-trapped firms.

For these reasons, I expect the following: 


\section{$\mathrm{H}_{10 \mathrm{~b}}$ : A firm's network learning is negatively associated with the level of technology traps in its NPD processes.}

The direct link between network learning and routinization trap. There are two main reasons to expect that network learning may also reduce the occurrence of routinization traps. First, the broad external search involved in network learning is more likely to motivate firms to keep their NPD procedures updated and flexible over time. Broad network relationships provide firms with opportunities to share valuable information, experience, knowledge, resources, technology, and operation practices (Luo 2003). Through such network learning, firms may see very different NPD routines that may exist in other industries. This knowledge may motivate firms to experiment with new routines in their NPD process and discourage the kind of formalization that emerges from process inertia in NPD.

Second, the successful examples of different NPD routines that may be available from a broad network of learning partners may increase managers' willingness to go against industry norms and discount legitimacy threats in their NPD process management. Network learning extends firms' perceptions of what is normal and legitimate beyond its own industry (Beckman, Haunschild, and Phillips 2004). Network learning provides firms with unusual opportunities to see what others are doing with different NPD processes. When firms want to borrow the most successful NPD routines from their partners in other industries or markets, strong relationships may help firms be more successful in their process technology transfer efforts (Camp 1995). In this situation, managers may have the confidence to go against current industry norms and to experiment with novel NPD routines that competitors may not consider legitimate. 
Thus, I expect the following:

\section{$H_{10 c}$ : A firm's network learning is negatively associated with the level of routinization trap in its NPD processes.}

Creating superior customer value is the key objective of MO (Slater and Narver 1995). From this perspective, firms' ideas concerning how to create superior values are based on knowledge derived from customer and competitor analyses. However, a market-oriented firm should not underestimate the potential contributions of other learning sources, such as suppliers, businesses in different industries, consultants, universities, government agencies, and others that possess knowledge valuable to creating superior customer value (Dickson 1992; Slater and Narver 1995). For example, Vorhies and Morgan (2005) argue that marketoriented firms learning from outside their own industry are less prone to blind spots. Their results show that firms are better off benchmarking marketing capabilities across all firms rather than just focusing on peer firms in their own industries.

As previously argued, because of MO's focus on the proximate environment of customers and competitors, and internal orientation on interfunctional coordination, MO may not encourage broad external search and can therefore lead to competency traps. In the following section, I propose that network learning plays a moderating role in the link between MO and competency traps. In this moderating role, I suggest that external learning from the wider environment is a complement to MO that provides a broader external orientation (Slater and Narver 1995). By providing broad external search and diverse external knowledge, network learning may weaken the tendency of market-oriented firms to have a 
narrow focus on existing customers, competitors, and cross-functional relationships that facilitate the development of competency traps in the NPD process.

The moderating role of network learning in the link between market orientation and vision trap. In a moderating role, network learning is a valuable complementary asset to MO (Slater and Narver 1995). As argued in previous hypotheses, MO may lead to vision traps because it focuses on what existing customers want and what existing competitors are doing. According to $\mathrm{H}_{3 \mathrm{a}}$, customer orientation may limit firms' vision because of existing customers' preference inertia, the utility of customer opinions as a source of new product ideas, and the stability of existing customer populations. However, network learning may broaden the scope of customer orientation by opening firms to a new and fresh worldview from external learning partners, such as distributors, suppliers, alliance partners, universities, and others. Broad external search introduces very dissimilar NPD knowledge and different customer populations from external network partners (Powell, Koput, and Smith-Doerr 1996; YliRenko, Autio, and Sapienza 2001). This may enable firms to avoid the limiting visions available solely from a customer orientation and motivate firms to seek fresh ideas from outside their proximate market environment (Li and Rowley 2002; Nerkar and Roberts 2004). Therefore, when a firm has a high level of network learning, novel and diverse knowledge from network partners is likely to weaken the relationship between MO and vision traps.

Similarly, as argued in $\mathrm{H}_{4 \mathrm{a}}$, a competitor orientation may limit firms' NPD vision by promoting imitative learning from competitors. However, network learning emphasizes a focus beyond competitors in the industry, thereby broadening external learning and widening 
the conception of sources of legitimacy to those outside a firm's own industry. This external orientation may effectively reduce competitor-oriented firms' imitative learning behavior (Vorhies and Morgan 2005) and encourage them to experiment with new NPD approaches from outside the industry. Thus, network learning may weaken the relationship between competitor orientation and vision traps.

According to $\mathrm{H}_{5 \mathrm{a}}$, interfunctional coordination may limit firms' vision by fostering conformity, groupthink, and narrow internal orientation. However, network learning brings an external orientation beyond interdepartmental coordination and promotes broad external search in organizational learning. Furthermore, exemplars in other industries of how to smooth interdepartmental communication in challenging projects may also help firms with a focus on interfunctional coordination overcome the problems of conformity and groupthink. Therefore, network learning may weaken the link between interfunctional coordination and vision traps.

Thus, I argue:

\section{$H_{11 a}$ : A firm's network learning weakens the positive relationship between its MO and vision traps in its NPD processes.}

The moderating role of network learning in the link between market orientation and technology trap. In high network-learning firms, MO is less likely to create technology traps. According to $\mathrm{H}_{3 \mathrm{~b}}$, a customer orientation may lead to technology traps because of customers' limited technology knowledge and preferences for existing technologies (Adner 2002; Im and Workman 2004). Customer-oriented firms tend to make technology-selection decisions

on the basis of existing customers' feedback (e.g., Christensen, Suarez, and Utterback 1998). 
However, network learning may supplement customer feedback and thus broaden the firms' NPD vision by providing relevant information regarding technologies used and advocated by external learning partners and the preferences of their partners' customers in other industries (Vorhies and Morgan 2005). This information and knowledge from network learning may reduce customer-oriented firms' uncertainty regarding whether its customers would accept a new technology and provide insights regarding how customers may best be educated about a different new technology if it is adopted. In this situation, a customer-oriented firm is less likely to stick with technologies just because they are familiar and more certain for existing customers.

Similarly, as argued in $\mathrm{H}_{4 \mathrm{~b}}$, a competitor orientation may also lead to technology traps because it encourages the imitation of competitors' technologies (Lukas and Ferrell 2000; Zahra, Nash, and Bickford 1995). However, network learning may weaken this link by broadening the firm's knowledge of available and emerging technologies and enabling the firm to see these "in action" outside of the proximate industry environment. Network learning may also enable competitor-oriented firms to see different new technologies in other industries as legitimate, enabling them to control the uncertainty associated with new and emerging technologies (Beckman, Haunschild, and Phillips 2004). Therefore, network learning may weaken the relationship between competitor orientation and technology traps.

According to $\mathrm{H}_{5 \mathrm{~b}}$, a focus on interfunctional coordination may also lead to technology traps, because the pressures to avoid sources of conflict encourages the use of familiar technologies in NPD (Argyris 1982; Carmel 1995; Crawford 1992; Lukas and Ferrell 2000). However, network learning may provide opportunities for firms to discover very different new NPD routines that can be successfully implemented by cross-functional teams in other 
industries. Such successful examples from broad external search may decrease managers' fear of legitimacy threats and increase managers' confidence to go against industry norms in NPD.

For these reasons I expect the following:

\section{$H_{11 b}$ : A firm's network learning weakens the positive relationship between its MO and technology traps in its NPD processes.}

The moderating role of network learning in the link between market orientation and routinization trap. In firms with strong learning networks, $\mathrm{MO}$ is also less likely to create routinization traps. As argued in $\mathrm{H}_{3 c}$, customer orientation may lead to routinization traps because of customers' preference stability, trade-offs between cost and innovation, and relatively stable customer populations. However, network learning may weaken or break this link. Network learning introduces a broader external search and an orientation beyond the narrow focus of existing customers (Slater and Narver 1995). Broad network relationships may provide firms with opportunities to see different new NPD routines in other industries, how these are accepted by their partners' customers, and whether novel NPD routines produce benefits above and beyond their costs for their network partners. Successful examples may increase firms' confidence to abandon industry norms and to experiment with new routines in their NPD process (Camp 1995).

According to $\mathrm{H}_{4 \mathrm{c}}$, a competitor orientation may also lead to routinization traps because of its strong cost and efficiency focus, tendency toward imitative learning from competitors, and prioritization of threats to legitimacy. However, network learning may reduce or even sever this link. Network learning may broaden competitor-oriented firms' 
narrow competitor focus and supplement it with a broader external orientation (Slater and Narver 1995). Network partners' experiences with different new NPD routines may help the firm reduce any uncertainty toward the potential cost and benefit of experimentation in NPD efforts (Luo 2003). Successful examples of different new NPD routines in other industries may discourage the competitor-mimetic learning tendency in competitor-oriented firms. Furthermore, a wider conception of legitimacy and industry norms may motivate firms to follow the steps of partners outside the proximate industry environment and enable a firm to introduce radical new NPD routines to the industry.

According to $\mathrm{H}_{5 \mathrm{c}}$, a strong focus on interfunctional coordination may also lead to routinization traps because of its internal orientation and pressures to avoid sources of conflict that encourage the use of familiar NPD routines. However, network learning supplements the internal orientation of a focus on interfunctional coordination with a broader external orientation (Yli-Renko, Autio, and Sapienza 2001). Network partners may provide good examples of how cross-functional teams can be effectively coordinated in firms using different NPD processes. This kind of partnership help firms codify the coordination process of how cross-functional teams in successful learning partners in other industries reduce groupthink and enhance communication in challenging new NPD projects. In this situation, firms with a strong focus on interfunctional coordination are more likely to keep their NPD procedures updated and flexible over time.

For these reasons, I argue:

\section{$\mathrm{H}_{11 \mathrm{c}}$ : A firm's network learning weakens the positive relationship between MO and routinization traps in its NPD processes.}




\section{CHPATER 4: METHODOLOGY DESIGN}

This dissertation aims to model the up- and downside effects of market orientation (MO) on competency traps and new product innovation. Due to the exploratory nature of this study, new measurements, including competency traps and network learning, must be developed in order to test the model. On the basis of my research goals, I selected the fieldstudy method to collect data because this approach may enhance the external validity, applicability, and acceptability of results from empirical studies (Cook and Campbell 1979).

\subsection{Questionnaire Survey and Questionnaire Design}

Survey research has many advantages. First, survey research has relatively high levels of validity, because researchers can pose questions that directly address the underlying nature of a construct (Lyon, Lumpkin, and Dess 2000). Survey measures can gauge intent and depict the processes associated with firm strategies (Lyon, Lumpkin, and Dess 2000).

Second, to enhance content validity, surveys can be developed that contain a sufficiently comprehensive set of items to represent the subject matter of interest. Convergent and discriminant validity techniques can be used to determine the adequacy of such measures (Mason and Bramble 1989). Third, unlike measures that aggregate broadly across firms in an industry, perceptual measures are also useful for measuring current conditions within a firm with a high degree of specificity (Lyon, Lumpkin, and Dess 2000). Thus, multi-item scales 
and survey instruments ensure high construct validity. Scale items that have forced-choice responses can also contribute to greater measurement validity. Moreover, the survey approach enables the testing of theoretical relationships in this study in different industrial settings. Because this study is at the early stage of theory development, survey study is appropriate for the development of concepts, frameworks, and theories (Bonoma 1985; Eisenhardt 1989; Hirschman 1986; Zaltman, LeMasters, and Heffring 1982).

There are two practical reasons to use a questionnaire survey in this study. First, a questionnaire survey can efficiently generate large amounts of data that can be subjected to statistical analysis (Snow and Thomas 1994). Second, it is necessary to allow respondents maximum discretion in answering the questionnaire, since many organizations consider sensitive a discussion of the "darkside" effects of any strategies, competency traps, or compensation strategies.

I followed the following procedures to develop the questionnaire. First, previous studies related to each variable in the framework were reviewed. Most measures in the questionnaire were chosen from those that had been employed in previous research. If the variables had satisfying quality in previous literature variables, they were adopted. Second, on the basis of constitutive definitions of the constructs and relevant literature, new measures, which previous research did not provide, were created through pretest.

Third, in order to enhance the content validity of each scale, a panel with three researchers evaluated the instrument for problems with the content and wording of individual items prior to the administration. If one judge objected to an item, the item was either reworded to dismiss the objection or deleted from the final instrument. 
Fourth, one experienced researcher on the subject in China was hired to translate the original English questionnaire into Chinese. Another experienced researcher was hired to back-translate from Chinese to English. Back-translation enables the enhanced validity of the cross-cultural setting. The original questionnaire and back-translated questionnaire were compared in order to detect any misunderstanding due to translation. The errors were detected and corrected. (For the final questionnaire, see appendix A.)

\subsection{Sampling Method}

\subsubsection{The Cross-Sectional Field Study}

Cross-sectional data were chosen from different industries as a sample of new product innovation firms. The cross-sectional approach was chosen to enable the collection of relatively low-cost data from a large, diverse sample. Although the effectiveness of the conclusions regarding the causality of this approach may be challenged, it was adopted because of this study's exploratory nature.

\subsubsection{Sample Frame and Selection Process}

The data collection occurred in China rather than in the United States. The purpose of this study is to understand whether a capability may lead to a rigidity, which then causes competency traps. Rigidity happens in complex and dynamic environments with threats or crisis. China is experiencing a transitional economy, which is more unstable and dynamic but full of opportunities (Lau, Tse, and Zhou 2002) compared with the economy in the United

States. Competency traps should be more salient and important in Chinese companies than in 
American companies. Therefore, China is a more suitable setting to test my framework on the rigidity of competency traps.

The study sample derives from different industries in Beijing, Shanghai, Guangzhao, and Shenzhen in China. There are approximately five industries included in this study: (1) electronic information; (2) new energy; (3) new materials; (4) new pharmaceuticals, or bioengineering; and (5) integrated optical-mechanical and electronics. This relatively broad range of industries helps improve generalizability in the sample.

Only firms within the high-technology zone were included in the sample, because these firms were highly likely to have active NPD activities. The selection criteria included the following: (1) the firm produces new products, (2) the firm has an R\&D department or special engineers to develop new products, and (3) the new product has been sold in the market.

The sample frame was obtained from the management office of the high-technology zone. Around 600 firms with NPD projects were included in the first vision sample frame. The research assistant made a phone call to each firm and asked whether it was willing to participate in the research. In this study, the unit of analysis was designed at the firm level rather than the project level or the product level.

In order to reach valid conclusions about populations from samples, random sampling is the best way to reduce bias and gain the ability to generalize (Sekaran 1992). The disadvantage of this method is that the process is cumbersome and expensive. Because of time and budget limitations, this study adopted the availability sampling method, which is an alternative to random sampling (Keppel, Saufley, and Tokunaga 1992). This method collects 
data from the companies that are willing to participate in the research. Therefore, the subject is free to decide whether to participate in the research.

\subsubsection{Respondents}

Common-method variance problems occur when independent and dependent measures are collected from the same individuals (Rousseau 1978; Vecchio 1982). In order to reduce common-method bias, two respondents were chosen (one marketing manager and one R\&D manager, both of whom were deeply involved in NPD) from each firm to measure different constructs. There were 300 respondents from 150 firms that were expected to answer the questionnaires.

\subsection{Data Collection}

\subsubsection{Scale Development}

Before the major survey, the measurement development was conducted first. Given the rather novel nature of this research, two new scales were required for the key constructs of competency traps and network learning. In order to develop better measures, the procedure suggested by Churchill (1979) was followed. First, on the basis of a thorough literature review, the constructs were conceptualized to specify the construct domain and to generate the items for the constructs. Second, in order to establish face validity and content validity, a list of measure items with the definitions of the constructs was submitted to a panel of experienced academic researchers and practitioners. Through many rounds of modification, the new scales were well refined. Third, a pretest was conducted among MBA and EMBA students. In order to check discriminant validity, several similar constructs, such as willingness to cannibalize and balance 
between exploitation and exploration, were included in the pretest. In the pretest, 46

questionnaires were collected. Fourth, to purify the measures, a comprehensive analysis was conducted — including exploratory factor analysis, reliability assessment, and confirmatory factor analysis - to check the unidimensionality, reliability, construct convergent validity, and discriminant validity in SPSS and AMOS. Fifth, a panel with experienced academic researchers checked the pretest results and made decisions about the measures' revision and purification on the basis of the reliability and validity assessment.

\subsubsection{Data-Collection Procedures}

A major weakness of a questionnaire survey is nonresponse bias, which may lead to a poor sample and affect both the reliability of the research and the types of data analysis (Davis and Cosenza 1993; Emory and Cooper 1991; Neuman 1994). Nonresponse bias may be reduced through proper design of data-collection procedures, such as the avoidance of ambiguous questions, the provision of training to the research assistant, and the use of preliminary notification and follow-ups (Armstrong and Overton 1977; Churchill 1995).

A senior research assistant was hired for data collection. To overcome the difficulties of a low response rate and the high costs of survey research in China (e.g., Calantone, Schmidt, and Song 1996), an administered-on-site method was used to collect questionnaires. Snow and Thomas (1994) suggest the use of an administered-on-site method to improve the response rate. This method requires the research assistant to have a face-to-face interview and ask respondents to complete the questionnaire during the interview. In order to control quality, the research assistants were asked to bring back a business card from each 
respondent, the firm's brochure, and an official chop, or a signature of the respondent with the address on the questionnaire.

The questionnaire collection was implemented as follows. First, the research assistant explained the purpose of the study to the respondents of the selected firms. In order to get accurate information and minimize social desirability, a rich explanation of the significance of the research was presented in the beginning of the questionnaire. In order to reduce the complexity, ambiguity burden, and consistency for judgment, the informant was told to fill out the questionnaire based on simple facts rather than past opinions or beliefs formed from reading the introduction of the questionnaire. In order to improve the reliability and validity of the data by using a structured questionnaire, the respondents were instructed to answer each question in terms of the actual situation rather than the ideal situation. In addition, in order to assure the respondents of confidentiality, they were reminded that there were no right or wrong answers to the questions. The questionnaire also included the statement, "I guarantee confidentiality of all information, am honest about procedures, and am only interested in the general and scientific collection of data." The research assistant needed to fit the interviews into the respondents' schedules.

\subsection{Data Analysis and Measurements}

Structure equation modeling with measurement models and path models was used to test my hypotheses and framework. All constructs were measured by multi-items. I planned to collect both primary and secondary data to provide a multimethod approach for purposes of triangulation and measurement validation. All subjective measures were assessed by a 
seven-point Likert-type scale. All scales are available upon request. I briefly outline the key constructs below.

\subsubsection{Dependent Variables}

New product performance (NPP) is the dependent variable in this study. It was measured both subjectively and objectively.

$N P P$. Objective measures included (1) number of line extensions, me-too products, and newto-the-world products in the last three years (Lukas and Ferrell 2000), (2) percentage of sales of new products introduced in the last three years, (3) percentage of sales provided by new products less than three years old, (4) percentage of profits provided by new products less than three years old, (5) percentage of market share from new products less than three years old, and (6) percentage of sales growth from new products less than three years old.

Five dimensions were measured in subjective NPP.

First, for overall NPP (Moorman 1995), respondents were asked to rate the extent to which their new products had achieved the following outcomes relative to their original objectives during the first 12 months of their life in the marketplace: (1) market share, (2) sales, (3) profit margin, and (4) ROI.

Second, new product creativity (modified from Andrews and Smith 1996) was measured by the following: (1) is really "out of the ordinary," (2) can be considered revolutionary, (3) is stimulating, (4) reflects a customer perspective from industry norms, (5) is radically different from industry norms, and (6) shows an unconventional way of solving problems. 
Third, for NPD speed (modified from Rindfleisch and Moorman 2001), respondents were asked to circle a number that best indicates their assessment of NPD activities in their companies: (1) usually behind our time goals-usually ahead of our time goals, (2) slower than the industry average-faster than the industry average, (3) much slower than we expected-much faster than we expected, and (4) much slower than our competitors-much faster than our competitors.

Fourth, for new product advantage (modified from Li and Calantone 1998), respondents were asked to rate the extent to which their new product is superior to that of their largest competitor along the following dimensions: (1) reliability: our new products are free of errors compared with the competitor's products; (2) compatibility: our new products are compatible with other products and better than competitor's products; (3) uniqueness: our product offers unique benefits to customers that are not provided by the competitor's products; (4) ease of use: our new products are easier to learn and use than competitor's products; (5) productivity: our new products increase a customer's work efficiency more than competitor's products; (6) functionality: our new products solve problems customers have with competitor's products; and (7) quality: customers perceive the quality as significantly higher than that of competitor's products.

Fifth, for new product resource efficiency (new scale), respondents were asked to rate the resources consumed in NPD. (1) more than expected-less than expected, (2) far exceeded budget-well under budget, (3) many resources consumed-few resources consumed, and (4) exceeding plan-less than plan.

\subsubsection{Independent Variables}


Three types of independent variables were included: the independent variable of MO; the mediating variable of competency traps; and the moderating variables of EO, network learning, and environmental uncertainty. The MO measure was adapted from the work of Narver and Slater (1990). The EO measure was modified from the work of Matsuno, Mentzer, and Ozsomer (2002) and Liu, Luo and Shi (2002). Competency traps and network learning are new scales developed in this study. The environmental uncertainty (technology and demand uncertainty) measures were adapted from the work of Jaworski and Kohli (1993).

Market orientation. On the basis of Narver and Slater' (1990) study, MO has three dimensions. First is customer orientation, measured by six items: (1) We constantly monitor our level of commitment and orientation to serving customers needs, (2) Our business strategies are driven by our beliefs about how we can create greater value for our customers, (3) Our strategy for competitive advantage is based on our understanding of customers needs, (4) Our business objectives are driven primarily by customer satisfaction, (5) We measure customer satisfaction systematically and frequently, and (6) We give close attention to aftersales services.

Second is competitor orientation, measured by four items: (1) Our salespeople regularly share information within our business concerning competitor strategies, (2) We rapidly respond to competitive actions that threaten us, (3) Top managers regularly discuss competitors' strengths and strategies, and (4) We target customers where we have opportunities for competitive advantage. 
Third is interfunctional coordination, measured by five items: (1) Our top managers from every function regularly visit our current and prospective customers, (2) We freely communicate information about our successful and unsuccessful customer experiences across all business functions, (3) All of our business functions (e.g., marketing/sales, manufacturing, R\&D, finance/accounting) are integrated in serving the needs of our target markets, (4) All of our managers understand how everyone in our business can contribute to creating customer value, and (5) We share resources with other business units.

Competency traps. Competency traps have three dimensions: (1) vision trap, (2) technology traps, and (3) routinization traps. Competency traps have three dimensions and 18 items: vision trap, technology trap, and routinization trap. Each dimension includes six items.

Vision traps. The respondents were asked to think about how the company develops new products and indicate the extent to which they agreed with the following statements: (1) Our confidence in our NPD process is based on its past success rather than its current performance; (2) We believe that the past success of our NPD process makes it the best approach for the future; (3) Because of its past success, people tend to ignore current weaknesses in our NPD approach; (4) Our pride in the past success of our NPD processes blinds us to opportunities for improvement; (5) Despite contrary indications, people still believe our NPD approach is better than that of our rivals; and (6) The past success of our NPD process inhibits attempts to experiment with new approaches.

Technology traps. With respect to the new products developed in the past year, respondents were asked to consider the following statements: (a) We have incorporated a lot 
of technology that is new to the industry, (b) We have only used technologies already proved in the marketplace, (c) The technologies we have used are well known in this industry, (d) We have used tried and tested methods, (e) We have tended to stick with what we know, and (f) The technologies we have incorporated have all been mature.

Routinization traps. With respect to NPD, respondents were asked to consider the following statements: (a) We have well-understood "rules," (b) Our procedures are highly formalized, (c) Our procedures can be easily changed, (d) We never relax our standard procedures, (e) Our procedures are not very standardized, and (f) We follow formalized procedures.

EO (modified). Matsuno, Mentzer and Özsomer (2002) and Liu, Luo and Shi (2002) developed the scales for EO, and these scales were modified to fit the research setting. This scale has three dimensions: (1) innovativeness, (2) risk-taking propensity, and (3) proactiveness.

(1) Innovativeness. (a) When it comes to problem solving, we value creative new solutions more than the solutions of conventional wisdom; (b) We encourage the development of innovative marketing strategies, even knowing well that some will fail; (c) Relative to our competitors, our company has higher ability to implement experimentation and original approaches to problems; and (d) Relative to our competitors, our company has higher level of innovation and R\&D.

(2) Risk taking. (a) We value the orderly and risk-reducing management process much more highly than leadership initiatives for change; (b) We like to play safe; (c) We like to implement plans only if they are very certain that they will work; (c) Relative to our 
competitors, our company has higher propensity to take risks; and (d) Relative to our competitors, our company has a strong proclivity for high-risk goals with chances of high returns.

(3) Proactiveness. (a) We firmly believe that a change in market creates a positive opportunity for us; (b) We tend to talk more about opportunities rather than problems; (c) Relative to our competitors, our company has a higher tendency to engage in strategic planning activities;(d) Relative to our competitors, our company has a higher ability to identify new opportunities; and (e) Relative to our competitors, our company has a higher ability to persevere in making our visions of the business a reality.

Network learning. Two methods were used to measure network learning. The first measurement was developed on the basis of the works of Gatignon and Xuereb (1997) and Rindfleisch and Moorman (2001). The respondents were asked about the extent to which they agreed with the following statements about their companies' relationships with outside companies and organizations (e.g., suppliers, distributors, consultants, retailers, banks, government contacts, university contacts, employment agencies, technology search firms): (1) We put substantial effort into learning from outside companies and organizations; (2) We have strong relationships with companies and organizations outside of our industry, (3) We benefit from close contacts with companies and organizations outside of our industry, (4) We have learned a lot from interactions with companies and organizations outside of our industry, (5) We have gained significant knowledge from companies and organizations outside of our industry, and (6) We have partners from a wide variety of different industries. 
For the second measurement, respondents were asked how much insight or knowledge their companies gain from relationships with the following in their NPD efforts: (1) suppliers, (2) distributors, (3) consultants, (4) retailers, (5) peer companies outside of our industry, (6) government contacts, and (7) university contacts.

Technology uncertainty. The technology uncertainty measurement from the work of Jaworski and Kohli (1993) was modified as follows: (1) The technology in our industry was changing quite rapidly, (2) Technological changes provided big opportunities in our industry, (3) A large number of new product ideas have been made possible through technological breakthroughs in our industry, (4) There have been major technological developments in our industry, and (5) It is very difficult to predict where the technology in our industry will be in the next two or three years.

Demand uncertainty. The demand uncertainty from Jaworski and Kohli (1993) was adopted: (1) Our customers tend to look for new products all the time, (2) The product preferences of our customers change quite rapidly, (3) We are witnessing demand for our product from customers who never bought from our firm before, (4) New customers tend to have product needs that are quite different from existing customers, (5) Demand is hard to forecast in this product industry.

\subsubsection{Control Variables}

To prevent model misspecification error and to control the potential confounding effects, several control variables are included in this dissertation: strategy types (Matsuno and 
Mentzer 2000), balance between exploitation and exploration (Kim and Atuahene-Gima 2004); competition intensity (Jaworski and Kohli 1993), past performance (Geletkanycz 1997), perceived industry dominance (Chandy, Prabhu, and Antia 2003), willingness to cannibalize (Chandy and Tellis 1998), firm size and age, and so on.

Strategy types. The strategy-type scale was adopted from the work of Matsuno and Mentzer (2000).

(1) Defender. This type of business unit attempts to locate and maintain a secure niche in a relatively stable product or service area. The business unit tends to offer a more limited range of products and services than its competitors, and it tries to protect its domain by offering higher quality, superior service, lower price, and so forth. Often this business unit is not at the forefront of development in the industry, and it tends to ignore industry changes that have no direct influence on current areas of operation and concentrates instead on doing the job possible in a limited area.

(2) Prospector. This type of business unit typically operates within a broad productmarket domain that undergoes periodic definition. The business unit values being "first in" in new product and market areas, even if not all of these efforts prove to be highly profitable. This organization responds rapidly to early signals concerning the area of opportunity, and these responses often lead to a new round of competitive actions. However, this business unit may not maintain market strength in all of the areas it enters.

(3) Analyzer. This type of business unit attempts to maintain a stable, limited line of products or services while at the same time moving quickly to follow a carefully selected set of the more promising new developments in the industry. This organization is seldom "first in" with new product and services. However, by carefully monitoring the action of major 
competitors in areas compatible with its stable product-market base, this business can carefully be "second in" with more cost-efficient product or services.

(4) Reactor. This type of business unit does not appear to have consistent productmarket orientation. This organization is usually not as aggressive in maintaining established products and markets as some of its competitors, nor is it willing to take as many risks as other competitors. Rather this type of business unit responds in those areas where it is forced to by environmental pressures.

Balance between exploitation and exploration in NPD (new scales). Based on the works of March (1991) and Levinthal and March (1993), Kim and Atuahene-Gima (2004) develop a scale for exploitation and a scale for exploration. In this dissertation, those scales were modified by combining them in one scale with two poles. Respondents were asked to circle a number that best indicated their assessments of NPD activities in their companies for each of the following statement pairs: (1) We frequently undertake novel NPD projects that we are far from certain we can successfully complete versus We usually undertake NPD projects that we are certain we can successfully complete; (2) We often develop new product ideas for emerging or anticipated market needs versus We only develop new product ideas that meet existing market needs; (3) Most of our NPD projects require us to develop new knowledge and areas of expertise versus Most of our NPD projects tap our existing areas of knowledge and expertise; (4) We are always experimenting with new ways of developing new products versus We always use tried and tested NPD approaches; and (5) We frequently undertake NPD projects that let us experiment with new technologies versus We only undertake NPD projects where we can exploit existing technologies. 
Competition intensity. Six items were adapted from Jaworski and Kohli (1993) to measure this construct: (1) Competition in this product industry is cutthroat; (2) There are many promotion wars in this product industry; (3) One hears of a new competitive move almost every day; (4) Price competition is a hallmark of this product industry; (5) Anything that one competitor can offer, others can match readily; and (6) Competitors are relatively weak.

Past performance. Based on the work of Hambrick, Geletkanycz, and Fredrickson (1993) and Geletkanycz (1997), respondents perceptions of their firm's performance was captured by asking them to describe their organization's profitability on a four-item scale, where 1 = unprofitable, 2 = breaking even, $3=$ moderately profitable, and $4=$ very profitable.

Perceived industry dominance. Based on the work of Chandy, Prabhu, and Antia (2003) five items were developed to measure the construct of perceived industry dominance:

(1) Our performance so far has been better than that of everyone else in our industry, (2) We have had few serious threats to our position as industry leaders so far, (3) We had led the market from the start, (4) We have control in our industry, and (5) Other firms try to follow us in the technology. 


\section{CHAPTER 5: DATA ANALYSES AND DISCUSSION}

This chapter outlines the characteristics of the sample, including participating firms and respondents, measurement development, and the major findings in this study. The first section introduces the characteristics of the sample, including participating firms and respondents. The second section discusses the measurement development, including reliability and validity issues of the constructs. Then the results of this study are presented. The last section presents the findings of the hypotheses testing.

\subsection{Characteristic of the Sample}

\subsubsection{Response Rates}

A total of 600 firms were invited to participate in the final survey between July 2004 and September 2004. Two respondents were required for each firm's participation. A total of 302 usable questionnaires from 151 firms were received, representing a $25.17 \%$ response rate. This response rate is acceptable in marketing. Given the on-site data collection, a test of response bias by comparison of early and late respondents was not appropriate. 


\subsubsection{Characteristics of Firms and Respondents}

Before providing the data description of firms and respondents, I explain the careful screening of the missing data. If some characteristics of firms and respondents were missing in the questionnaires but are available from the secondary sources provided, I checked the secondary sources (e.g., brochures, Web sites) and filled in the missing data with the located information. In addition, outliers were also checked and screened by matching the information from secondary sources.

A major concern for the sample frame was the selection of appropriate managers as primary informants. My original plan was to get one marketing manager and one $\mathrm{R} \& \mathrm{D}$ manager from each firm in order to reduce common-method bias. However, the actual sample frame (302 usable questionnaires from 151 firms) from the data collection included 158 marketing managers and only $34 \mathrm{R} \& \mathrm{D}$ managers. The rest of the respondents included $36 \mathrm{CEOs,} 15$ from manufacturing departments, 15 from finance and accounting departments, 37 from administration departments, and 7 from unknown departments. In this situation, the original plan to reduce common-method bias could not be implemented by this sample frame. Therefore, I decided to only use the questionnaire of one marketing manager from each firm to test the hypotheses. When two marketing managers from the same firm answered the questionnaires, I chose the questionnaire from the manager who indicated him- or herself as having a longer experience in the firm or in the position and as having better knowledge about NPD. As a result, 113 marketing managers' questionnaires were selected for the final data analysis.

This section summarizes the major characteristics of 113 firms and respondents. Table 5.1 provides the descriptive statistics for the major characteristics of firms and 
respondents in the final survey. The mean firm age is 12.53 , and the standard deviation (STD) is 10.31 . The mean firm size is 930.35 and STD is 1954.93. A total of 113 marketing respondents in this survey have worked in their companies for approximately five years $($ mean $=5.32, \mathrm{STD}=2.73)$ and have been in the same job position for approximately three years $($ mean $=3.57, \mathrm{STD}=1.98)$. Their knowledge of NPD activities over the past year is high $($ mean $=6.15, \mathrm{STD}=1.85$; on a ten-point scale $)$.

\section{Table 5. 1 Characteristics of Firms and Respondents}

\begin{tabular}{|l|l|l|}
\hline Variable & \multicolumn{1}{|c|}{ Mean } & \multicolumn{1}{c|}{ STD } \\
\hline Firm's age & 12.53 & 10.31 \\
\hline Firm's size & 930.35 & 1954.93 \\
\hline & & \\
\hline Respondents' experience in the firm & 5.32 & 2.73 \\
\hline Respondents' experience in the position & 3.57 & 1.98 \\
\hline Respondents' knowledge about NPD & 6.15 & 1.85 \\
\hline
\end{tabular}

Table 5.2 reports the industry type of the participating firms. As noted previously, the firms were sampled from a high-tech industrial zone in China. According to the first respondent, the major industries in the sample include electronics and information technology $(10$, or $8.8 \%)$, computer and software $(2$, or $1.8 \%)$, telecommunications $(5$, or $4.4 \%)$, integrated optical mechanical and electronic (26, or $23 \%)$, chemical, pharmaceutical, or biotechnology $(11$, or $9.7 \%)$, new energy and materials $(44$, or $38.9 \%)$, and other $(12$, or $10.6 \%)$. Three companies did not indicate their industry type. The profile of industry types provides evidence that the sample includes a broad variety of industries. Thus, research findings of this study can be generalized to most high-tech industries. 


\section{Table 5. 2 Types of Business for Participating Firms}

\begin{tabular}{|l|l|l|}
\hline Variable & Number & Percentage \\
\hline 1. Electronics and information technology & 10 & $8.8 \%$ \\
\hline 2. Computer and software & 2 & $1.8 \%$ \\
\hline 3. Telecommunications & 5 & $4.4 \%$ \\
\hline 4. Integrated optical mechanical and electronic & 26 & $23 \%$ \\
\hline 5. Chemical/pharmaceutical/biotechnology & 11 & $9.7 \%$ \\
\hline 6. New energy and materials & 44 & $38.9 \%$ \\
\hline 7. Other & 12 & $10.6 \%$ \\
\hline Missing & 3 & $2.7 \%$ \\
\hline Total & 113 & $100 \%$ \\
\hline
\end{tabular}

Table 5.3 reports the ownership o the participating firms. Four types of ownership are included: (1) state-owned company $(10$, or $8.8 \%),(2)$ private company $(56$, or $49.6 \%),(3)$ collectively owned company (3, or $2.7 \%)$, and (4) joint venture and foreign company (38, or 33.6\%). Six companies did not indicate their ownership.

\section{Table 5. 3 Ownership of Participating Firms}

\begin{tabular}{|l|l|l|}
\hline Variable & Number & Percentage \\
\hline 1. State-owned company & 10 & $8.8 \%$ \\
\hline 2. Private company & 56 & $49.6 \%$ \\
\hline 3. Collectively owned company & 3 & $2.7 \%$ \\
\hline 4. Joint venture and foreign company & 38 & $33.6 \%$ \\
\hline Missing & 6 & $5.3 \%$ \\
\hline Total & 113 & $100 \%$ \\
\hline
\end{tabular}

\subsection{Measurement Development}

The development of valid and reliable measures was a first major step before hypotheses testing. One of the main challenges of this dissertation is to develop a new measure for competency traps and network learning, because there is no available measure for these in the existing literature. 
To determine whether the empirical responses to measure items are consistent with the hypothesized conceptual constructs, researchers must identify scale items that map the empirical data on the hypothesized measurement model. The evaluation of scale items and composite scales sometimes produces results that require the model's respecification. In this section, I discuss the procedures for measurement development before going into the detail about two new measures: (1) competency traps and (2) network learning. Then, I review and respecify measurement models for the other major constructs on the basis of an empirical analysis of the collected data. For most of the other constructs, existing measures were tested for validity and reliability prior to their adoption in the study. In the end, I discuss the results of the confirmatory factor analysis and tests of convergent and discriminant validity.

\subsubsection{General Procedure for Measure Development}

To develop valid and reliable measures for constructs is critical to theory testing. Churchill (1979) suggests the following steps for measure development: (1) specification of the construct domain on the basis of a literature review, (2) generation of a pool of items on the basis of a literature review and an exploratory survey and interview, (3) data collection, (4) purification of the measure using coefficient alpha and exploratory factor analysis, and (5) assessment of reliability and validity. These steps involve an iterative process. At each stage, the researchers evaluate the results and decide whether to proceed to the next step or to modify the measure and repeat the same procedure. This study follows the above iterative steps through pretest and final survey. Section 4.3.1 shows the steps that were completed before the final survey. Table 5.4 summarizes the pretest 


\section{Table 5. 4 Summary for Measurements Before and After Pretest $(\mathrm{N}=46)$}

\begin{tabular}{|c|c|c|c|c|c|}
\hline Construct & $\begin{array}{l}\text { Original } \\
\text { Item No. }\end{array}$ & $\begin{array}{l}\text { Retained } \\
\text { Item No. }\end{array}$ & $\begin{array}{l}\text { Modified } \\
\text { Scale } \\
\text { Property }\end{array}$ & $\begin{array}{c}\text { Decisions } \\
\text { for Final } \\
\text { Survey }\end{array}$ & Sources \\
\hline \multicolumn{6}{|c|}{ Dependent Variables } \\
\hline Objective NPP: 1 & 3 & $\mathrm{~N} / \mathrm{A}$ & N/A & & $\begin{array}{l}\text { Lukas and Ferrel } \\
(2000)\end{array}$ \\
\hline Objective NPP: 2 & 5 & N/A & N/A & & N/A \\
\hline Overall subjective NPP & 5 & 4 & $\begin{array}{l}\alpha=0.84 \\
\chi^{2}=4.98 \\
\text { d.f. }=2 \\
p=0.083\end{array}$ & $\begin{array}{l}\text { Delete } 1 \\
\text { item }\end{array}$ & Moorman (1995) \\
\hline New product creativity & 7 & 4 & $\begin{array}{l}\alpha=0.84 \\
\chi^{2}=1.907 \\
\text { d.f. }=2 \\
p=0.385\end{array}$ & $\begin{array}{l}\text { Delete } 1 \\
\text { item }\end{array}$ & $\begin{array}{l}\text { Andrews and } \\
\text { Smith (1996) }\end{array}$ \\
\hline NPD speed & 6 & 4 & $\begin{array}{l}\alpha=0.88 \\
\chi^{2}=2.46 \\
\text { d.f. }=2 \\
p=0.292\end{array}$ & $\begin{array}{l}\text { Delete } 2 \\
\text { item }\end{array}$ & $\begin{array}{l}\text { Rindfleisch and } \\
\text { Moorman (2001) }\end{array}$ \\
\hline New product advantage & 7 & 5 & $\begin{array}{l}\alpha=0.89 \\
\chi^{2}=8.44 \\
\text { d.f. }=5 \\
p=0.133\end{array}$ & & $\begin{array}{l}\text { Li and Calantone } \\
\text { (1998) }\end{array}$ \\
\hline $\begin{array}{l}\text { New product resources } \\
\text { efficiency }\end{array}$ & 4 & 4 & $\begin{array}{l}\alpha=0.71 \\
\chi^{2}=2.844 \\
\text { d.f. }=2 \\
p=0.241\end{array}$ & & New \\
\hline \multicolumn{6}{|c|}{ Independent variables } \\
\hline $\mathrm{MO}$ & & & $\begin{array}{l}\alpha=0.83 \\
\chi^{2}=45.98 \\
\text { d.f. }=32 \\
p=0.052\end{array}$ & & $\begin{array}{l}\text { Narver and Slater } \\
(1990)\end{array}$ \\
\hline Customer orientation & 6 & 3 & & & \\
\hline Competitor orientation & 4 & 4 & & & \\
\hline $\begin{array}{r}\text { Interfunctional } \\
\text { coordination }\end{array}$ & 5 & 3 & & & \\
\hline EO & & & $\begin{array}{l}\alpha=0.89 \\
\chi^{2}=44.90 \\
\text { d.f. }=32 \\
p=0.065\end{array}$ & & $\begin{array}{l}\text { Matsuno, Mentzer, } \\
\text { and Ozsomer } \\
\text { (2002), Liu, Luo, } \\
\text { and Shi (2002) }\end{array}$ \\
\hline Innovativeness & 4 & 3 & & & \\
\hline Risk taking & 5 & 3 & & & \\
\hline Proactiveness & 5 & 4 & & & \\
\hline Network learning1 & 6 & 5 & $\begin{array}{l}\alpha=0.93 \\
\chi^{2}=7.779 \\
\text { d.f. }=5 \\
p=0.169\end{array}$ & & $\begin{array}{l}\text { Gatignon and } \\
\text { Xuereb (1997), } \\
\text { Rindfleisch and } \\
\text { Moorman (2001) } \\
\end{array}$ \\
\hline Network learning2 & 7 & 5 & $\begin{array}{l}\alpha=0.61 \\
\chi^{2}=5.24 \\
\text { d.f. }=5 \\
p=0.388\end{array}$ & & $\begin{array}{l}\text { Gatignon and } \\
\text { Xuereb (1997), } \\
\text { Rindfleisch and } \\
\text { Moorman (2001) }\end{array}$ \\
\hline
\end{tabular}




\begin{tabular}{|c|c|c|c|c|c|}
\hline \multicolumn{6}{|c|}{ Control Variables } \\
\hline Technology uncertainty & 5 & 5 & $\begin{array}{l}\alpha=0.93 \\
\chi^{2}=2.003 \\
\text { d.f. }=5 \\
p=0.849\end{array}$ & & $\begin{array}{l}\text { Jaworski and Kohli } \\
\text { (1993) }\end{array}$ \\
\hline Demand uncertainty & 5 & 4 & $\begin{array}{l}\alpha=0.76 \\
\chi^{2}=5.414 \\
\text { d.f. }=2 \\
p=0.067\end{array}$ & & $\begin{array}{l}\text { Jaworski and Kohli } \\
\text { (1993) }\end{array}$ \\
\hline Strategy types & 6 & 5 & $\begin{array}{l}\alpha=0.39 \\
\chi^{2}=23.21 \\
\text { d.f. }=5 \\
p=0.00\end{array}$ & $\begin{array}{l}\text { Delete } 2 \\
\text { items }\end{array}$ & $\begin{array}{l}\text { Matsuno and } \\
\text { Mentzer (2000) }\end{array}$ \\
\hline $\begin{array}{l}\text { Balance between } \\
\text { exploitation and } \\
\text { exploration in NPD }\end{array}$ & 5 & 4 & $\begin{array}{l}\alpha=0.70 \\
\chi^{2}=3.185 \\
\text { d.f. }=2 \\
p=0.203\end{array}$ & & New \\
\hline Willingness to cannibalize & 6 & 4 & $\begin{array}{l}\alpha=0.65 \\
\chi^{2}=1.47 \\
\text { d.f. }=2 \\
p=0.479\end{array}$ & & $\begin{array}{l}\text { Chandy and Tellis } \\
\text { (1998) }\end{array}$ \\
\hline Competition intensity & 6 & 4 & $\begin{array}{l}\alpha=0.82 \\
\chi^{2}=5.347 \\
\text { d.f. }=2 \\
p=0.069\end{array}$ & $\begin{array}{l}\text { Delete 2 } \\
\text { items }\end{array}$ & $\begin{array}{l}\text { Jaworski and Kohli } \\
\text { (1993) }\end{array}$ \\
\hline Past performance & 4 & & & & $\begin{array}{l}\text { Hambrick, } \\
\text { Geletkanycz, and } \\
\text { Fredrickson } \\
\text { (1993); } \\
\text { Geletkanycz } \\
\text { (1997) }\end{array}$ \\
\hline $\begin{array}{l}\text { Perceived industry } \\
\text { dominance }\end{array}$ & 5 & 4 & $\begin{array}{l}\alpha=0.81 \\
\chi^{2}=1.855 \\
\text { d.f. }=2 \\
p=0.396\end{array}$ & & $\begin{array}{l}\text { Chandy, Prabhu, } \\
\text { and Antia (2003) }\end{array}$ \\
\hline
\end{tabular}

instruments in terms of the number of original items, the number of retained items, decisions done after pretest for the final survey, and source of the measures.

The following sections focuses on new measure development: competency traps. In the measure-validation process, Gerbing and Anderson (1988) recommend that unidimensionality should be included, except for reliability and validity assessment. Therefore, coefficient alpha, item-to-total correlation, exploratory factor analysis, and 
confirmatory factor analysis in structural equation modeling are used for measure validation process in this study.

\subsubsection{Development of Competency Traps: Pretest Study Validation}

In the pretest, a total of 24 items collected from the literature review and exploratory interviews were initially proposed for 4 dimensions of competency traps: (1) confidence, (2) familiarity, (3) maturity, and (4) routinization. Each dimension has six items. Table 5.5 summarizes the results from this pretest with 46 respondents.

First, coefficient alpha was examined for all four dimensions to examine internal consistency. The results show that all the dimensions have good internal consistency, as reflected in a high coefficient alpha for each dimension ( 0.89 for confidence traps, 0.87 for familiarity traps, 0.82 for maturity traps, and 0.83 for routinization traps).

Second, a corrected item-to-total correlation represents the correlation of a single item with the sum of all other items. "Alpha if item deleted" shows what the scale's alpha value would be if that single item is removed. "Item-to-total" and "alpha if deleted" values are used to help remove poor items from scales. According to "alpha if deleted" values, none of the items should be deleted in order to improve the scale's alpha.

Third, confirmatory factor analyses were conducted for each dimension of competency traps, on the basis of the pretest data, to examine the fit of the measurement model. The measurement model examines the relationship of observed indicators to their underlying dimension of competency traps and provides a confirmatory assessment of convergent validity. 
The chi-square statistic shows an overall assessment of model fit by testing the hypotheses that all of the differences between the observed and implied covariances are zero simultaneously. Familiarity trap and routinization trap have good model fits with the data. Confidence trap and maturity trap do not have very desirable model fits with the data, maybe because of the relatively small sample size in the pretest. When competency traps were tested as a high-order construct, a problem was identified. The other three subdimensions of competency traps are positively related to high-order construct competency traps, but not confidence traps $(\mathrm{r}=-0.58)$, which means that respondents perceive the items in confidence traps as positive confidence rather than dysfunctional confidence or overconfidence. In other words, items of confidence traps do not really measure "traps." Therefore, this dimension had to be rewritten in order to correctly measure the dysfunctional rather than the functional cognition. In the final survey, this dimension was renamed "vision traps."

Fourth, an exploratory factor analysis was performed with the principal axis extraction method to test the appropriateness of each item. After several rounds of deletion, a three-factor solution (see table 5.5) was derived on the basis of the eigenvalue rule (eigenvalue $>1$ ) and the visual examination of the scree plot for competency traps. The three factors explain a substantial amount of variance: $61.84 \%$. Three distinguishing dimensions can be found in the rotated factor matrix without any cross-loadings, which suggests that competency traps have three dimensions rather than four. Among four dimensions of competency traps, the respondents had no problem distinguishing confidence traps and routinization traps. But the respondents could not distinguish 


\section{Table 5. 5 Measure of Competency Traps Before and After Pretest $(\mathrm{N}=46)$}

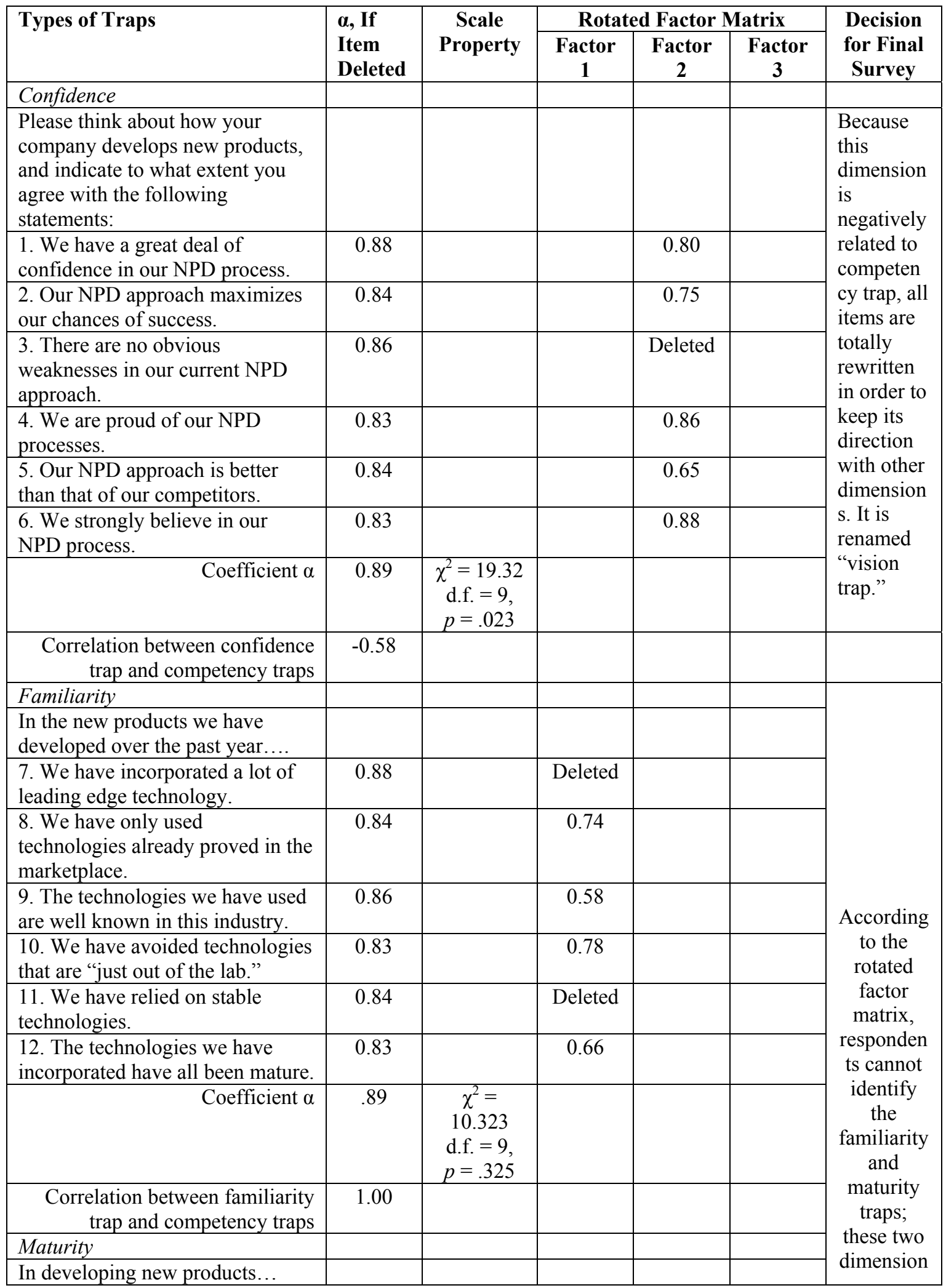




\begin{tabular}{|c|c|c|c|c|c|}
\hline 13. We use a familiar process. & 0.81 & & Deleted & & \multirow{8}{*}{$\begin{array}{c}\text { s are } \\
\text { combined } \\
\text { in the } \\
\text { final } \\
\text { survey } \\
\text { and } \\
\text { renamed } \\
\text { "technolo } \\
\text { gy trap." }\end{array}$} \\
\hline $\begin{array}{l}\text { 14. We use tried and tested } \\
\text { methods. }\end{array}$ & 0.81 & & Deleted & & \\
\hline $\begin{array}{l}\text { 15. We tend to stick with what we } \\
\text { know. }\end{array}$ & 0.77 & & 0.55 & & \\
\hline $\begin{array}{l}\text { 16. We incorporate familiar } \\
\text { technologies }\end{array}$ & 0.77 & & 0.80 & & \\
\hline $\begin{array}{l}\text { 17. We avoid technologies we } \\
\text { have not dealt with before. }\end{array}$ & 0.78 & & 0.77 & & \\
\hline $\begin{array}{l}\text { 18. We are not comfortable with } \\
\text { unfamiliar NPD methods. }\end{array}$ & 0.81 & & Deleted & & \\
\hline Coefficient $\alpha$ & 0.82 & $\begin{array}{c}\chi^{2}=30.41 \\
\text { d.f. }=9 \\
p=.00\end{array}$ & & & \\
\hline $\begin{array}{r}\text { Correlation between maturity trap } \\
\text { and competency traps }\end{array}$ & 0.85 & & & & \\
\hline \multicolumn{5}{|l|}{ Routinization } & \multirow{9}{*}{$\begin{array}{l}\text { No big } \\
\text { change in } \\
\text { this } \\
\text { dimension }\end{array}$} \\
\hline $\begin{array}{l}\text { 19. We have well-understood } \\
\text { "rules." }\end{array}$ & 0.80 & & & 0.68 & \\
\hline $\begin{array}{l}\text { 20. Our procedures are highly } \\
\text { formalized. }\end{array}$ & 0.78 & & & 0.78 & \\
\hline $\begin{array}{l}\text { 21. Our procedures can be } \\
\text { changed without formal approval. }\end{array}$ & 0.82 & & & Deleted & \\
\hline $\begin{array}{l}\text { 22. We never relax our standard } \\
\text { procedures. }\end{array}$ & 0.83 & & & Deleted & \\
\hline $\begin{array}{l}\text { 23. Our procedures are not very } \\
\text { standardized. }\end{array}$ & 0.83 & & & 0.53 & \\
\hline $\begin{array}{l}\text { 24. We closely follow formalized } \\
\text { procedures. }\end{array}$ & 0.75 & & & 0.84 & \\
\hline Coefficient $\alpha$ & 0.83 & $\begin{array}{c}\chi^{2}=12.78 \\
\text { d.f. }=9 \\
p=.17\end{array}$ & & & \\
\hline $\begin{array}{r}\text { Correlation between routinization } \\
\text { trap and competency traps }\end{array}$ & 0.52 & & & & \\
\hline
\end{tabular}

between familiarity traps and maturity traps, which led to the decision to combine the two dimensions, which were renamed "technology traps" after the pretest.

Thus, after the pretest, a 19-item Likert-type scale was used to measure 3 dimensions of competency traps in the final survey: 7 items for vision traps, 6 items for technology traps, and 6 items for routinization traps. 


\subsection{Data Analyses}

A total of 113 firms were included in the final study. A two-stage approach was employed to analyze the data and test the hypotheses. In the first stage, confirmatory factor analysis measurement models were assessed using AMOS. Once a suitable measurement model was obtained, a path model was identified using the structural models in the second stage. This two-stage approach has two advantages (Anderson and Gerbing 1988). First, it requires a smaller sample size because of the reduced model at each stage. The parameter estimates are more accurate and reliable, with a good ratio of the number of cases in sample frame per indicator or per latent variable when the sample size is relatively small. Second, it can avoid the potential confounding effect between the structural model and the measurement model. This section discusses the measurement model and structural model in confirmatory factory analysis. Table 5.6 provides the descriptive statistics and correlations. The correlation matrix is derived from the measurement model.

\subsubsection{Measurement Models}

Confirmatory factor analysis was used to estimate a measurement model. Five measurement models were estimated: (1) dependent variables (new product creativity, NPD speed, and NPD efficiency), (2) high-order MO (including customer orientation, competitor orientation, and cross-functional coordination), (3) high-order EO (innovativeness, risk taking, and proactiveness), (4) low-order competency traps (vision trap, technology trap, and routinization trap), and (5) network learning and control variables (technology uncertainty and competition intensity). Table 5.7 provides the fit 
Table 5. 6 Descriptive Statistics and Correlations of the Study Constructs $(a=0.001, b=0.05)$

\begin{tabular}{|c|c|c|c|c|c|c|c|c|c|c|c|c|c|c|c|}
\hline Construct & Mean & STD & 1 & 2 & 3 & 4 & 5 & 6 & 7 & 8 & 9 & 10 & 11 & 12 & 13 \\
\hline $\begin{array}{l}\text { 1. New product } \\
\text { creativity }\end{array}$ & 4.65 & 1.32 & - & & & & & & & & & & & & \\
\hline 2. NPD speed & 4.75 & 0.98 & $0.32^{\mathrm{a}}$ & - & & & & & & & & & & & \\
\hline $\begin{array}{l}\text { 3. New product } \\
\text { resource efficiency }\end{array}$ & 4.07 & 0.71 & 0.05 & $0.40^{\mathrm{a}}$ & - & & & & & & & & & & \\
\hline 4. MO & 4.84 & 1.01 & $0.40^{\mathrm{a}}$ & $0.50^{\mathrm{a}}$ & $0.31^{\mathrm{a}}$ & - & & & & & & & & & \\
\hline 5. Vision traps & 3.87 & 1.10 & -0.16 & 0.09 & 0.16 & 0.09 & - & & & & & & & & \\
\hline 6. Technology traps & 5.08 & 0.86 & 0.04 & $0.33^{\mathrm{a}}$ & 0.22 & $0.25^{\mathrm{a}}$ & 0.04 & - & & & & & & & \\
\hline 7. Routinization traps & 5.20 & 1.00 & $0.29^{\mathrm{a}}$ & $0.51^{\mathrm{a}}$ & $0.34^{\mathrm{a}}$ & $0.49^{\mathrm{a}}$ & 0.09 & 0.31 & - & & & & & & \\
\hline 8. EO & 4.75 & 0.96 & $0.33^{\mathrm{a}}$ & $0.58^{\mathrm{a}}$ & $0.40^{\mathrm{a}}$ & $0.70^{\mathrm{a}}$ & 0.15 & $0.25^{\mathrm{a}}$ & $0.40^{\mathrm{a}}$ & - & & & & & \\
\hline 9. Network learning & 4.95 & 1.10 & $0.31^{\mathrm{a}}$ & $0.43^{\mathrm{a}}$ & $0.19^{\mathrm{b}}$ & $0.48^{\mathrm{a}}$ & 0.12 & $0.40^{\mathrm{a}}$ & $0.45^{\mathrm{a}}$ & $0.38^{\mathrm{a}}$ & - & & & & \\
\hline $\begin{array}{l}\text { 10. Technology } \\
\text { uncertainty }\end{array}$ & 5.20 & 1.19 & $0.32^{\mathrm{a}}$ & $0.39^{\mathrm{a}}$ & $0.26^{\mathrm{a}}$ & $0.43^{\mathrm{a}}$ & 0.15 & $0.30^{\mathrm{a}}$ & $0.30^{\mathrm{a}}$ & $0.54^{\mathrm{a}}$ & $0.52^{\mathrm{a}}$ & - & & & \\
\hline $\begin{array}{l}\text { 11. Competition } \\
\text { intensity }\end{array}$ & 4.02 & 1.70 & $0.35^{\mathrm{a}}$ & $0.22^{b}$ & 0.11 & $0.57^{\mathrm{a}}$ & 0.01 & $-0.20^{b}$ & $0.30^{\mathrm{a}}$ & $0.27^{\mathrm{a}}$ & $0.23^{\mathrm{b}}$ & $0.19^{b}$ & - & & \\
\hline 12. Firm size & 930 & 1955 & $\begin{array}{l}-0.03 \\
\end{array}$ & 0.09 & -0.02 & 0.10 & -0.00 & 0.04 & -0.02 & 0.13 & 0.03 & 0.13 & 0.06 & - & \\
\hline 13. Firm age & 12.5 & 10.31 & -0.17 & 0.08 & 0.07 & 0.00 & -0.08 & 0.11 & 0.11 & -0.04 & 0.12 & 0.03 & 0.09 & $0.25^{\mathrm{a}}$ & - \\
\hline
\end{tabular}


indices of measurement models and the reliability of each construct. As indicated in Table 5.7, all measurement models exhibit acceptable fit indices. Each factor loading is positive and significant. The coefficient alpha, composite reliability, and average variance extracted also provide satisfactory evidence of reliability (coefficient alpha greater than 0.60 (composite reliability greater than 0.70 , according to Churchill 1979; average variance extracted greater than 0.50, according to Fornell and Larcker (1981).

\section{Table 5. 7 Measurement Models (from 113 Marketing Managers)}

\begin{tabular}{|c|c|c|}
\hline Constructs and Items & $\begin{array}{c}\text { Standardized } \\
\text { Coefficient }\end{array}$ & $t-$ Value $^{\mathrm{b}}$ \\
\hline \multicolumn{3}{|c|}{$\begin{array}{c}\text { Model 1: Dependent Variables } \\
\text { Model fit: } \chi_{(24)}^{2}=31.94, p=0.13 ; \mathrm{CFI}=.998 ; \mathrm{TLI}=.996 ; \mathrm{IFI}=.998 ; \mathrm{RMSEA}=.054\end{array}$} \\
\hline $\begin{array}{l}\text { Subjective new product creativity (Cronbach } \alpha=0.90 ; \text { composite reliability }= \\
0.90 ; \text { average variance extracted }=0.75 \text { ) }\end{array}$ & & scaling \\
\hline NPC2: fresh-routine & 0.818 & scaling \\
\hline NPC4: novel-predictable & 0.961 & 11.414 \\
\hline NPC6: unique-ordinary & 0.806 & 10.001 \\
\hline \multicolumn{3}{|l|}{$\begin{array}{l}\text { Subjective NPD speed (Cronbach } \alpha=0.92 ; \text { composite reliability }=0.92 \text {; average } \\
\text { variance extracted }=0.79) \\
\text { For each pair of statements below, please circle a number that best indicates your } \\
\text { assessment of the speed of the NPD activities in your company over the past } 12 \\
\text { months: }\end{array}$} \\
\hline NPS2: slower than the industry average-faster than the industry average & 0.884 & scaling \\
\hline NPS3: much slower than we expected-much faster than we expected & 0.896 & 12.957 \\
\hline NPS4: much slower than our competitors-much faster than our competitors & 0.878 & 12.583 \\
\hline \multicolumn{3}{|l|}{$\begin{array}{l}\text { Subjective NPD resource efficiency (Cronbach } \alpha=0.65 \text {; composite reliability }= \\
0.69 ; \text { average variance extracted }=0.44 \text { ) } \\
\text { Please consider your NPD efforts over the past } 12 \text { months. For each pair of } \\
\text { adjectives below, please circle a number that best indicates your assessment of the } \\
\text { resources consumed in NPD: }\end{array}$} \\
\hline NPE1: more than expected-less than expected & 0.572 & scaling \\
\hline NPE3: many resources consumed-few resources consumed & 0.531 & 4.184 \\
\hline NPE4: exceeding plan-less than plan & 0.837 & 4.260 \\
\hline \multicolumn{3}{|c|}{$\begin{array}{c}\text { Model 2: } \text { High Order Construct: } \text { EO } \\
\text { Model fit: } \chi_{(24)}^{2}=29.245, p=0.211 ; \mathrm{CFI}=.998 ; \mathrm{TLI}=.997 ; \mathrm{IFI}=.998 ; \mathrm{RMSEA}=.044\end{array}$} \\
\hline $\begin{array}{l}\text { Please indicate to what extent you agree with the following statements about your } \\
\text { company: }\end{array}$ & & \\
\hline $\begin{array}{l}\text { Customer orientation }(C T)(\text { Cronbach } \alpha=0.82 ; \text { composite reliability }=0.83 \text {; } \\
\text { average variance extracted }=0.63)\end{array}$ & 0.807 & scaling \\
\hline
\end{tabular}




\begin{tabular}{|c|c|c|}
\hline $\begin{array}{l}\text { CM3: Our strategy for competitive advantage is based on our understanding of } \\
\text { customers needs. } \\
\text { CM5: We measure customer satisfaction systematically and frequently. } \\
\text { CM6: We give close attention to after-sales service. }\end{array}$ & $\begin{array}{l}0.872 \\
0.864 \\
0.619\end{array}$ & $\begin{array}{r}7.004 \\
\text { scaling }\end{array}$ \\
\hline $\begin{array}{l}\text { Competitor orientation }(C P)(\text { Cronbach } \alpha=0.79 ; \text { composite reliability }=0.80 ; \\
\text { average variance extracted }=0.58)\end{array}$ & 1.087 & 4.471 \\
\hline $\begin{array}{l}\text { CP1: Our salespeople regularly share information within our business concerning } \\
\text { competitor strategies. }\end{array}$ & 0.753 & 6.358 \\
\hline $\begin{array}{l}\text { CP2: We rapidly respond to competitive actions that threaten us. } \\
\text { CP4: We target customers where we have opportunities for competitive advantage. }\end{array}$ & $\begin{array}{l}0.885 \\
0.613\end{array}$ & $\begin{array}{c}6.998 \\
\text { scaling }\end{array}$ \\
\hline $\begin{array}{l}\text { Cross-functional coordination }(C C)(\text { Cronbach } \alpha=0.81 ; \text { composite reliability }= \\
0.69 ; \text { average variance extracted }=0.44)\end{array}$ & 0.650 & 4.713 \\
\hline $\begin{array}{l}\text { CC3: All of our business functions (e.g., marketing/sales, manufacturing, R\&D, } \\
\text { finance/accounting) are integrated in serving the needs of our target markets. } \\
\text { CC4: All of our managers understand how everyone in our business can contribute } \\
\text { to creating customer value. } \\
\text { CC5: We share resources with other business units. }\end{array}$ & $\begin{array}{l}0.731 \\
0.766 \\
0.816\end{array}$ & $\begin{array}{r}7.208 \\
\text { scaling } \\
7.789 \\
\end{array}$ \\
\hline \multicolumn{3}{|c|}{$\begin{array}{c}\text { Model 3: High-Order Construct: EO } \\
\text { Model fit: } \chi_{(24)}^{2}=34.736, p=0.072 ; \mathrm{CFI}=.997 ; \mathrm{TLI}=.994 ; \mathrm{IFI}=.997 ; \mathrm{RMSEA}=.063\end{array}$} \\
\hline \multicolumn{3}{|l|}{ To what extent do the following statements describe your company? } \\
\hline $\begin{array}{l}\text { Innovativeness }(I N N)(\text { Cronbach } \alpha=0.90 ; \text { composite reliability }=0.88 \text {; average } \\
\text { variance extracted }=0.71)\end{array}$ & 1.000 & scaling \\
\hline $\begin{array}{l}\text { INN1: When it comes to problem solving, we value creative new solutions more } \\
\text { than the conventional wisdom. }\end{array}$ & 0.749 & scaling \\
\hline $\begin{array}{l}\text { INN3: Relative to our competitors, our company has a higher ability to implement } \\
\text { experimentation and original approaches to problems. }\end{array}$ & 0.949 & 10.489 \\
\hline INN4: Relative to our competitors, our company has higher levels of innovation. & 0.909 & 10.164 \\
\hline $\begin{array}{l}\text { Risk taking }(R T)(\text { Cronbach } \alpha=0.91 \text {; composite reliability }=0.91 \text {; average } \\
\text { variance extracted }=0.78)\end{array}$ & 0.515 & 3.641 \\
\hline $\begin{array}{l}\text { RT2: Top managers in this business unit do not like to "play it safe." } \\
\text { RT3: Top managers around here are happy to implement plans even if they are }\end{array}$ & $\begin{array}{l}0.875 \\
0.949\end{array}$ & $\begin{array}{l}\text { scaling } \\
13.809\end{array}$ \\
\hline uncertain that they will work. & & \\
\hline $\begin{array}{l}\text { RT4: Top managers around here are happy to implement plans even if they are } \\
\text { uncertain that they will work. }\end{array}$ & 0.822 & 11.333 \\
\hline $\begin{array}{l}\text { Proactiveness (Pro) }(\text { Cronbach } \alpha=0.74 ; \text { composite reliability }=0.74 \text {; average } \\
\text { variance extracted }=0.49)\end{array}$ & 0.743 & 3.643 \\
\hline $\begin{array}{l}\text { Pro2: Top managers in this business are proactive in seeking to create new } \\
\text { opportunities. }\end{array}$ & 0.610 & scaling \\
\hline $\begin{array}{l}\text { Pro3: Members of this business unit tend to talk more about opportunities rather } \\
\text { than problems. }\end{array}$ & 0.708 & 5.534 \\
\hline $\begin{array}{l}\text { Pro4: Relative to our competitors, our company has higher ability to generate new } \\
\text { opportunities. }\end{array}$ & 0.782 & 5.793 \\
\hline \multicolumn{3}{|c|}{$\begin{array}{c}\text { Model 4: Competency Traps } \\
\text { Model fit: } \chi_{(24)}^{2}=21.217, p=0.626 ; \mathrm{CFI}=1.000 ; \mathrm{TLI}=1.002 ; \mathrm{IFI}=1.001 ; \mathrm{RMSEA}=.000\end{array}$} \\
\hline $\begin{array}{l}\text { Vision traps }(V I S) \text { (Cronbach } \alpha=0.71 \text {; composite reliability }=0.75 \text {; average } \\
\text { variance extracted }=0.53) \\
\text { Please think about how your company develops new products, and indicate to what } \\
\text { extent you agree with the following statements: }\end{array}$ & & \\
\hline
\end{tabular}




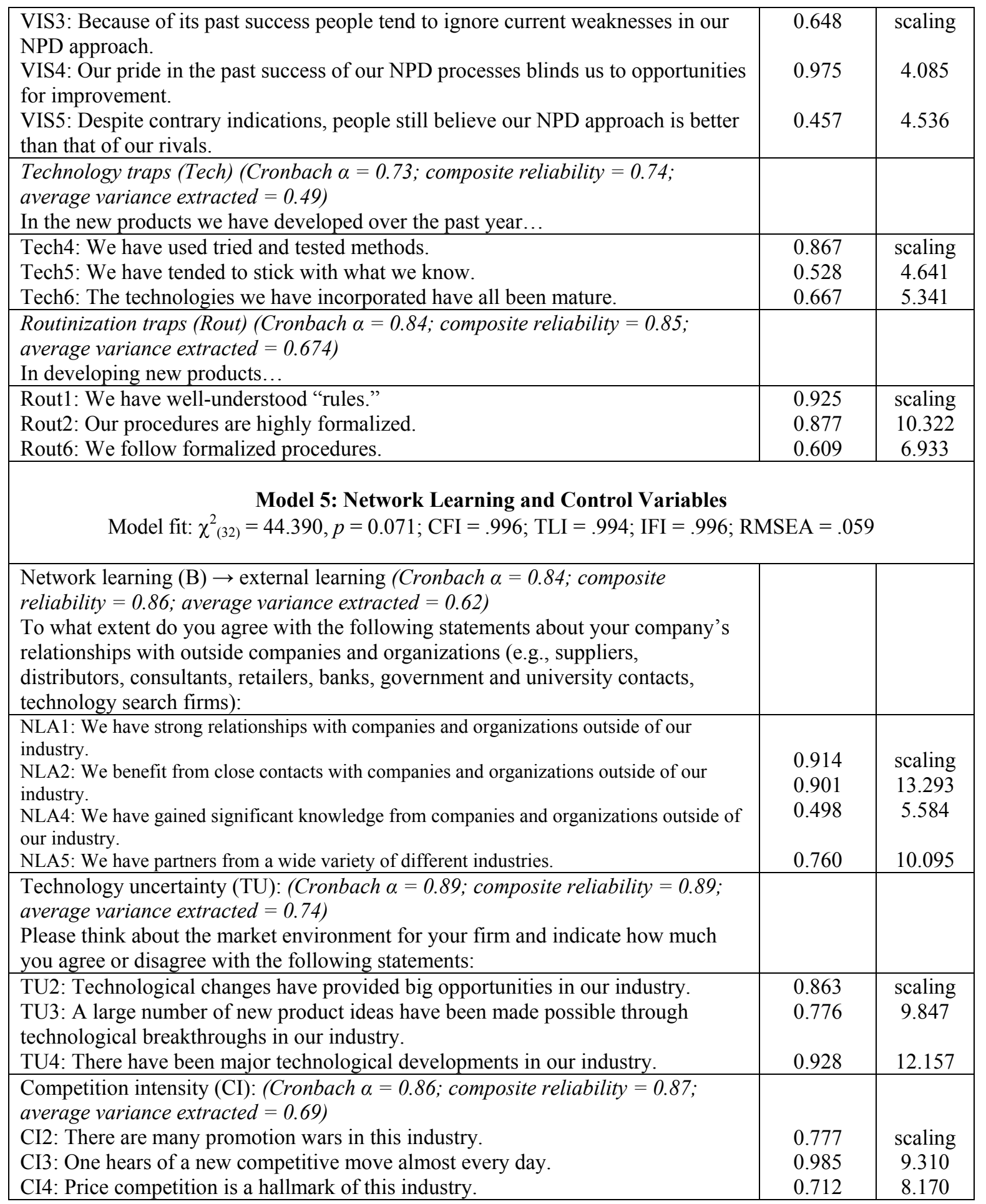




\section{Table 5. 8 Summary of Measurement Models}

\begin{tabular}{|c|c|c|c|}
\hline \multicolumn{4}{|l|}{ Dependent Variables } \\
\hline $\begin{array}{l}\text { New product creativity } \\
\text { NPD speed } \\
\text { NPD resource efficiency }\end{array}$ & $\chi^{2}=31.94($ d.f. $=24)$ & N.S. & $\begin{array}{l}\alpha=0.90, \\
\alpha=0.92, \\
\alpha=0.65\end{array}$ \\
\hline \multicolumn{4}{|l|}{ Independent Variables } \\
\hline $\begin{array}{l}\text { MO (high order) } \\
\text { Customer orientation } \\
\text { Competitor orientation } \\
\text { Cross-functional coordination }\end{array}$ & $\chi^{2}=21.25$ (d.f. $\left.=24\right)$ & N.S. & $\begin{array}{l}\alpha=0.82, \\
\alpha=0.79, \\
\alpha=0.88\end{array}$ \\
\hline EO (high order) & $\chi^{2}=35.71$ (d.f. $\left.=25\right)$ & N.S. & $\begin{array}{l}\alpha=0.90, \\
\alpha=0.91, \\
\alpha=0.74\end{array}$ \\
\hline Competency traps (low order) & $\chi^{2}=21.22$ (d.f. $\left.=24\right)$ & N.S. & $\begin{array}{l}\alpha=0.71, \\
\alpha=0.73, \\
\alpha=0.84\end{array}$ \\
\hline $\begin{array}{l}\text { Network learning } \\
\text { Technology uncertainty } \\
\text { Competitive intensity }\end{array}$ & $\chi^{2}=44.39$ (d.f. $\left.=32\right)$ & N.S. & $\begin{array}{l}\alpha=0.84, \\
\alpha=0.89, \\
\alpha=0.86\end{array}$ \\
\hline
\end{tabular}

\subsubsection{Structural Models}

This section reports the findings of the research. Two sets of relationships are included in this section. The first shows the results of the directional relationships $\left(\mathrm{H}_{1 \mathrm{a}-\mathrm{c}}-\mathrm{H}_{7 \mathrm{a}-}\right.$ c). The second demonstrates the moderating effects of EO and network learning $\left(\mathrm{H}_{8 \mathrm{a}-\mathrm{c}}-\mathrm{H}_{11 \mathrm{a}-}\right.$ c). Path analysis is used to assess the hypothesized model. Using structural question modeling methodology makes it possible to simultaneously test all the hypothesized relationships among constructs. Item-factor scores are averaged to form the factor scores for path analysis. When the moderations are tested, the independent variables are mean-centered for the interaction testing. 


\title{
5.3.2.1 Results of Hypotheses Testing: Direct Relationships $\left(\mathrm{H}_{1 \mathrm{a}-\mathrm{c}}-\mathrm{H}_{7 \mathrm{a}-\mathrm{c}}\right)$
}

In the first path model (see figure 5.1), the first 21 hypotheses are tested. The chisquare is 17.85 and not significant with $p$-values of 0.21 , which indicates a good overall model fit. Other fit indices of comparative fit index, Tucker Lewis index, incremental fit index, and root mean square error of approximation are respectively $0.999,0.995,0.999$, and 0.05. All the indices together suggest a very good model fit. In addition, the model attempts to control some confounding variables. Two important control variables are included: (1) firm age and (2) technology uncertainty. Firm age has a positive and significant association with new product creativity ( $b=0.22$, significant). Technology uncertainty has a positive and significant relationship with new product resource efficiency and new product creativity $(b=$ 0.18 , significant; and $\mathrm{b}=0.28$, significant, respectively). $\mathrm{H}_{1 \mathrm{a}-\mathrm{c}}-\mathrm{H}_{7 \mathrm{a}-\mathrm{c}}$ were tested after controlling for these two important, confounding variables.

\section{Figure 5.1 Direction Relationship}

\author{
Model Fit: Path Analysis \\ $\chi^{2}(14)=17.85, p=.21 ;$ CFI $=.999 ;$ TLI $=.995 ;$ IFI $=.999 ;$ RMSEA $=.05$
}

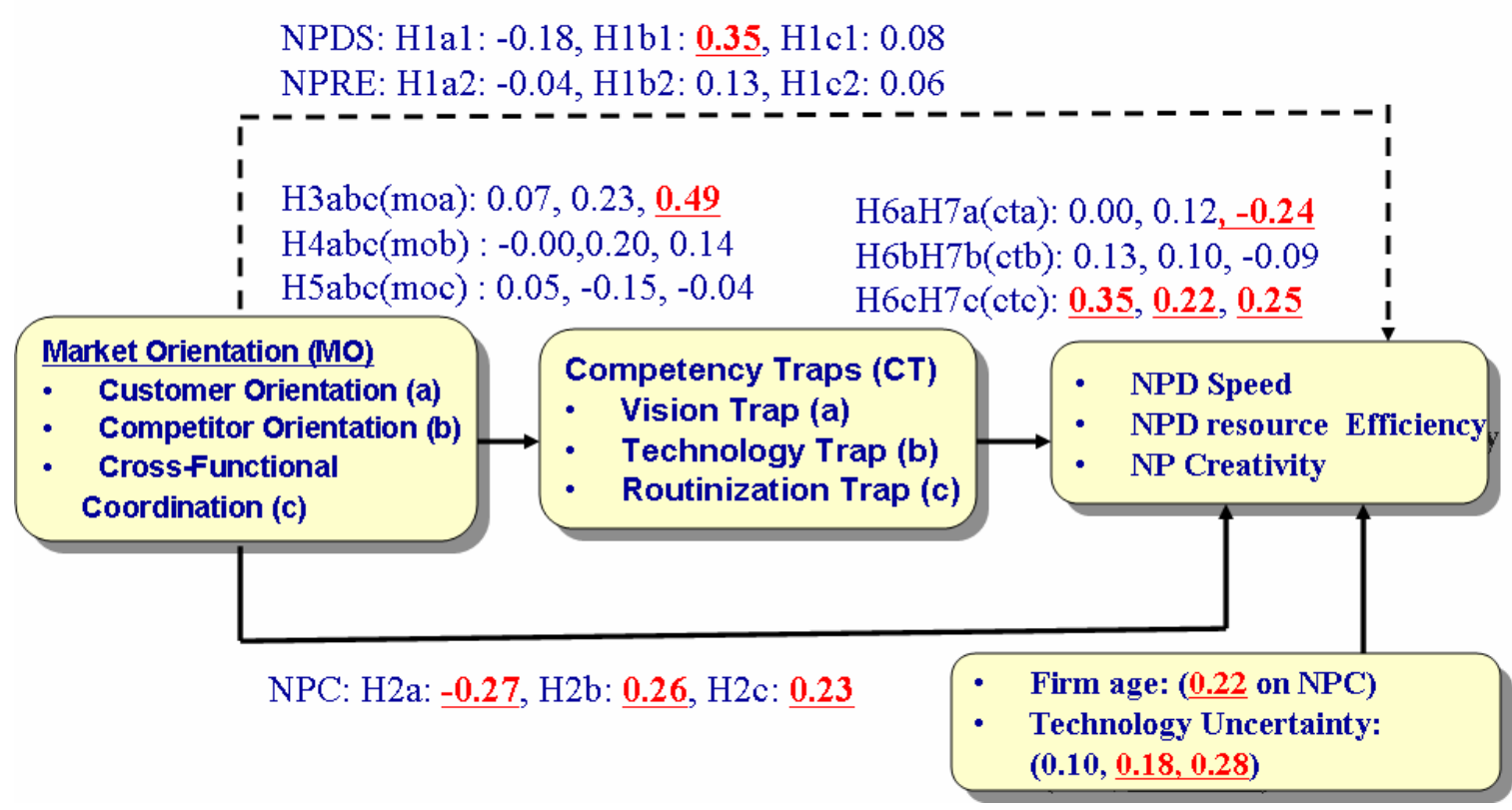


$\mathrm{H}_{1 \mathrm{a}}$ suggests that a firm's customer orientation is positively associated with its NPD efficiency, which includes two components: (1) NPD speed and (2) NPD resource efficiency. The path coefficients are negative and not significant (N.S.) between customer orientation and NPD speed and NPD resource efficiency $(b=-0.18$, N.S.; and $b=-0.04$, N.S., respectively). Therefore, $\mathrm{H}_{1 \mathrm{a}}$ is not supported.

$\mathrm{H}_{1 b}$ suggests that a firm's competitor orientation is positively associated with its NPD efficiency. The path coefficients are positive on NPD speed and NPD resource efficiency. However, only the relationship between competitor orientation and NPD speed is significant $(b=0.35$, significant), while the relationship between competitor orientation and NPD resource efficiency is not significant ( $b=0.13$, not significant). Therefore, $\mathrm{H}_{1 b}$ is partially supported.

$\mathrm{H}_{1 \mathrm{c}}$ states that a firm's interdepartmental coordination is positively associated with its NPD efficiency. This hypothesis is rejected by the data since the path coefficients are not significant on NPD speed and NPD resource efficiency $(b=0.08$, N.S.; and $b=0.06$, N.S., respectively).

$\mathrm{H}_{2 \mathrm{a}}$ proposes that a firm's customer orientation is positively associated with its NPD creativity. This hypothesis is refuted, since the path coefficient is negative rather than positive, although it is significant $(b=-0.27$, significant).

$\mathrm{H}_{2 \mathrm{~b}}$ suggests that a firm's competitor orientation is positively associated with its NPD creativity. This hypothesis is supported by the data. The path coefficient is positive and significant $(b=0.26$, significant $)$. 
$\mathrm{H}_{2 \mathrm{c}}$ suggests that a firm's interdepartmental coordination is positively associated with its NPD creativity. This hypothesis is supported by the data. The path coefficient is positive and significant $(b=0.23$, significant).

$\mathrm{H}_{3 \mathrm{a}}$ states that the higher a firm's customer orientation, the higher is the level of its vision trap. This hypothesis is not supported by the data. The path coefficient is positive but not significant $(b=0.07$, N.S.). Customer orientation does not have a significant relationship with vision trap.

$\mathrm{H}_{3 \mathrm{~b}}$ states the higher a firm's customer orientation, the higher is the level of its technology trap. This hypothesis is not supported by the data. The path coefficient is positive but not significant $(b=0.23$, N.S.). Customer orientation does not have a significant relationship with technology trap.

$\mathrm{H}_{3 \mathrm{c}}$ states the higher a firm's customer orientation, the higher is the level of its routinization trap. This hypothesis is supported by the data. The path coefficient is positive and significant $(\mathrm{b}=0.49$, significant). Customer orientation has a significant positive relationship with routinization trap.

$\mathrm{H}_{4 \mathrm{a}}$ states the higher a firm's competitor orientation, the higher is the level of its vision trap. This hypothesis is not supported by the data. The path coefficient is not significant $(b=-0.00$, N.S.). Competitor orientation does not have a significant relationship with vision trap.

$\mathrm{H}_{4 \mathrm{~b}}$ proposes the higher a firm's competitor orientation, the higher is the level of its technology trap. This hypothesis is not supported by the data. The path coefficient is positive but not significant $(b=0.20$, N.S.). Competitor orientation does not have a significant relationship with technology trap. 
$\mathrm{H}_{4 \mathrm{c}}$ suggests the higher a firm's competitor orientation, the higher is the level of its routinization trap. This hypothesis is not supported by the data. The path coefficient is positive and significant $(b=0.14$, N.S.). Competitor orientation does not have a significant, positive relationship with routinization trap.

$\mathrm{H}_{5 \mathrm{a}}$ states that the higher a firm's interdepartmental coordination, the higher is the level of its vision trap. This hypothesis is not supported by the data. The path coefficient is positive but not significant $(b=0.05$, N.S.). Interdepartmental coordination does not have a significant relationship with vision trap.

$\mathrm{H}_{5 \mathrm{~b}}$ proposes the higher a firm's interdepartmental coordination, the higher is the level of its technology trap. This hypothesis is not supported by the data. The path coefficient is negative and not significant $(b=-0.15$, N.S.). Interdepartmental coordination does not have a significant relationship with technology trap.

$\mathrm{H}_{5 \mathrm{c}}$ suggests that the higher a firm's interdepartmental orientation, the higher is the level of its routinization trap. This hypothesis is not supported by the data. The path coefficient is negative and not significant $(b=-0.04$, N.S.). Interdepartmental coordination does not have a significant, positive relationship with routinization trap.

$\mathrm{H}_{6 \mathrm{a}}$ states that the level of vision trap in a firm's NPD process is positively associated with its NPD efficiency. This hypothesis is not supported by the data. New product development efficiency includes two components: (1) NPD speed and (2) NPD resource efficiency. The path coefficient is not significant for both dependent components $(b=0.00$, N.S.; and $b=0.12$, N.S., respectively). Thus, vision trap does not have a significant relationship with either NPD speed or NPD resource efficiency. 
$\mathrm{H}_{6 \mathrm{~b}}$ states that the level of technology trap in a firm's NPD process is positively associated with its NPD efficiency. This hypothesis is not supported by the data. The path coefficient of technology trap is positive but not significant for both dependent components $(b=0.13$, N.S.; and $b=0.10$, N.S., respectively). Technology trap does not have a significant relationship with either NPD speed or NPD resource efficiency.

$\mathrm{H}_{6 \mathrm{c}}$ suggests that the level of routinization trap in a firm's NPD process is positively associated with its NPD efficiency. This hypothesis is partially supported by the data. The path coefficients of routinization trap on both NPD speed and NPD resource efficiency are significant and positive $(b=0.35$, significant; and $b=0.22$, significant, respectively).

$\mathrm{H}_{7 \mathrm{a}}$ states that the level of vision trap in a firm's NPD process is negatively associated with its NPD creativity. This hypothesis is supported by the data. The path coefficient is significant and negative $(b=-0.24$, significant). Vision trap has a significant, negative effect on NPD creativity.

$\mathrm{H}_{7 \mathrm{~b}}$ argues that the level of technology trap in a firm's NPD process is negatively associated with its NPD creativity. This hypothesis is rejected by the data. The path coefficient is not significant $(b=-0.09$, N.S.). Technology trap does not have a significant relationship with NPD creativity.

$\mathrm{H}_{7 \mathrm{c}}$ states that the level of routinization trap in a firm's NPD process is negatively associated with its NPD creativity. This hypothesis is refuted by the data. The path coefficient is significant and positive $(b=0.25$, significant). Thus, routinization trap has significant, positive relationship with NPD creativity. 


\title{
5.3.2.2 Results of Hypotheses Testing: Moderating Relationships $\left(\mathrm{H}_{8 \mathrm{a}-\mathrm{c}}-\mathrm{H}_{11 \mathrm{a}-\mathrm{c}}\right)$
}

In the second path model, the rest of the 12 hypotheses are tested. A best-fitting model is found and provided in Figure 5.2. The chi-square is 11.82 and not significant with the $p$-value of 0.38 , which indicates a good overall model fit. Other fit indices of comparative fit index, Tucker Lewis index, incremental fit index, and root mean square error of approximation are respectively $1.000,0.998,1.000$, and 0.026 . All the indices together suggest a very good model fit. Moreover, this model attempts to control some confounding variables. $\mathrm{H}_{8 \mathrm{a}-\mathrm{c}}-\mathrm{H}_{11 \mathrm{a}-\mathrm{c}}$ were tested after controlling for the negative effect of firm size. $\mathrm{H}_{8 \mathrm{a}-\mathrm{c}}$ suggest that the higher a firm's EO, the lower are the levels of its vision, technology, and

\section{Figure 5.2 Moderating Relationship}

\author{
Best Fitting Model: Path Analysis \\ $\chi^{2}(11)=11.82, p=.38 ;$ CFI $=1.00 ;$ TLI $=.998 ;$ IFI $=1.00 ;$ RMSEA $=.026$
}

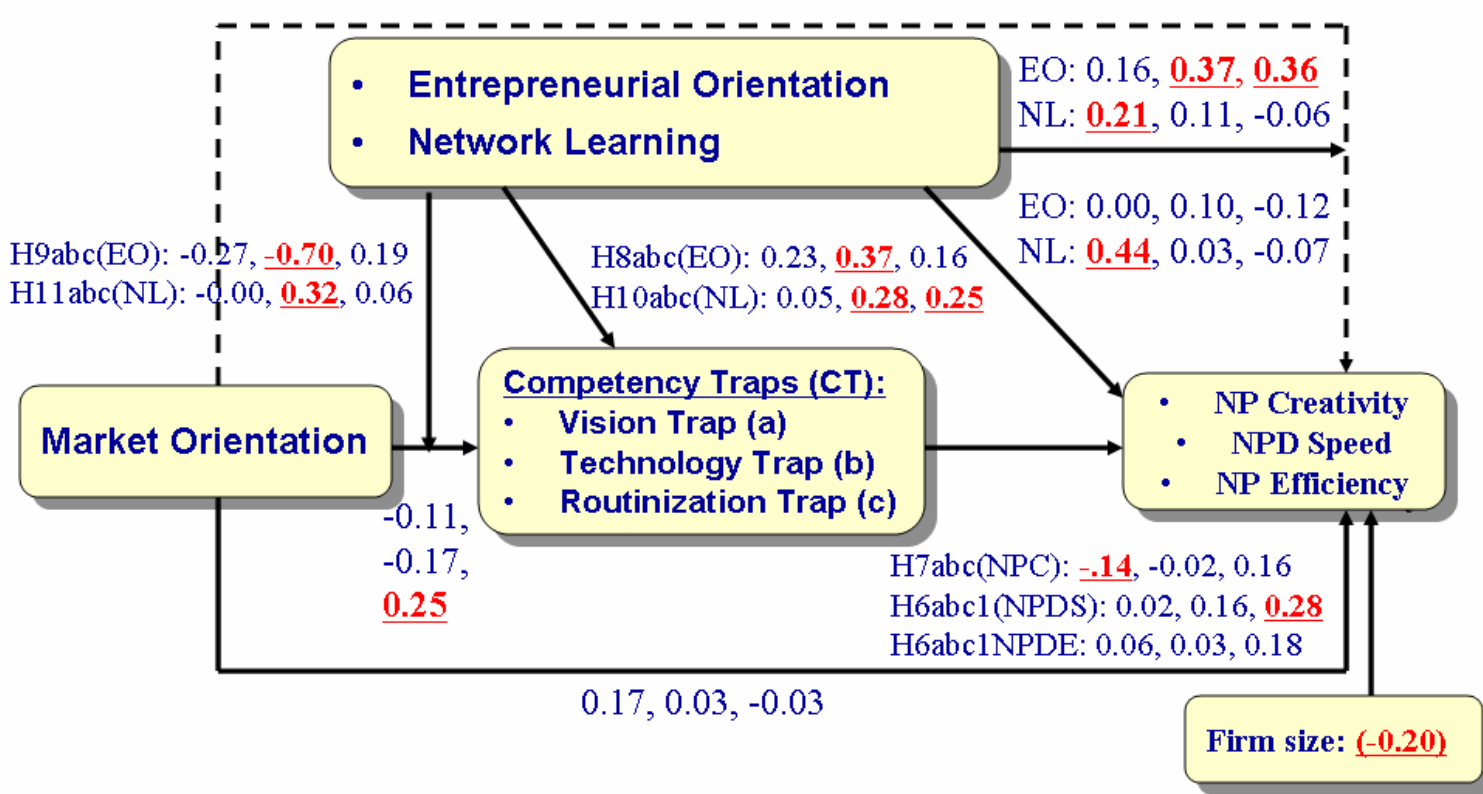


routinization traps in its NPD process. The data refute $\mathrm{H}_{8 \mathrm{~b}}$ and reject $\mathrm{H}_{8 \mathrm{a}}$ and $\mathrm{H}_{8 \mathrm{c}}$. The path coefficients of EO are positive and significant for technology trap $(b=0.37$, significant $)$ but not significant for vision trap and routinization trap $(b=0.23$, N.S.; and $b=0.16$, N.S., respectively). Therefore, a firm's EO has a positive relationship with technology trap but no significant relationship with vision or routinization traps.

$\mathrm{H}_{9 \mathrm{a}-\mathrm{c}}$ suggest that a firm's EO weakens the positive relationship between its $\mathrm{MO}$ and the vision, technology, and routinization traps in its NPD process. The data only support $\mathrm{H}_{9 b}$ and reject $\mathrm{H}_{9 \mathrm{a}}$ and $\mathrm{H}_{9 \mathrm{c}}$. The interaction effect between $\mathrm{MO}$ and $\mathrm{EO}$ is negatively related to technology trap $(b=-0.70$, significant $)$ but has no association with vision trap and routinization trap $(b=-0.27$, N.S.; and $b=0.19$, N.S., respectively).

$\mathrm{H}_{10 \mathrm{a}-\mathrm{c}}$ suggest that a firm's network learning is negatively associated with the levels of vision, technology, and routinization traps in its NPD process. The data support $\mathrm{H}_{10 \mathrm{~b}}$ and $\mathrm{H}_{10 \mathrm{c}}$ but reject $\mathrm{H}_{10 \mathrm{a}}$. The path coefficients of network learning are positive and significant for technology trap and routinization trap $(b=0.28$, significant; and $b=0.25$, significant, respectively) but not significant for vision trap $(b=0.05$, N.S.). Therefore, a firm's network learning has a positive relationship with technology trap and routinization trap but not with vision trap.

$\mathrm{H}_{11 \mathrm{a}-\mathrm{c}}$ suggest that a firm's network learning weakens the positive relationship between its MO and the vision, technology, and routinization traps in its NPD processes. The data only support $\mathrm{H}_{11 \mathrm{~b}}$ and reject $\mathrm{H}_{11 \mathrm{a}}$ and $\mathrm{H}_{11 \mathrm{c}}$. The interaction effect between $\mathrm{MO}$ and network learning is positively related to technology trap $(b=0.32$, significant $)$ but has no association with vision trap and routinization trap $(b=-0.00$, N.S.; and $b=0.06$, N.S., respectively). 


\subsection{Discussion of the Results}

This section discusses the empirical findings presented in the previous sections in detail in terms of the literature. The results indicate that (1) a firm's competitor orientation is positively associated with its NPD resource efficiency but not with its NPD speed; (2) a firm's customer orientation is negatively associated with its NPD creativity; (3) a firm's competitor orientation is positively associated with its NPD creativity; (4) a firm's interdepartmental coordination is positively associated with its NPD creativity; (5) the higher a firm's customer orientation, the higher is the level of its routinization trap; (6) the level of routinization trap in a firm's NPD process is positively associated with its NPD efficiency; (7) the level of vision trap in a firm's NPD process is negatively associated with its NPD creativity; (8) the level of routinization trap in a firm's NPD process is positively associated with its NPD creativity; (9) the higher a firm's EO, the higher is the level of its technology trap; (10) a firm's EO weakens the positive relationship between its $\mathrm{MO}$ and technology trap in its NPD process; (11) a firm's network learning is positively associated with the level of technology trap in its NPD processes; (12) a firm's network learning is positively associated with the level of routinization trap in its NPD processes; and (13) a firm's network learning strengthens the positive relationship between its MO and technology trap in its NPD processes (see table 5.9). 


\section{Table 5.9 Summary of Findings}

\begin{tabular}{|c|c|c|c|}
\hline & Context of Hypotheses & & Findings \\
\hline 1. & $\begin{array}{l}\mathrm{H}_{1 \mathrm{a}} \text { : A firm's customer orientation is positively associated with its NPD } \\
\text { efficiency }\end{array}$ & + & Not Supported \\
\hline 2. & $\begin{array}{l}\mathrm{H}_{1 \mathrm{~b}} \text { : A firm's competitor orientation is positively associated with its NPD } \\
\text { efficiency }\end{array}$ & + & 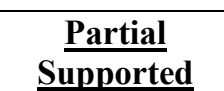 \\
\hline 3. & $\begin{array}{l}\mathrm{H}_{1 \mathrm{c}} \text { : A firm's interdepartmental coordination is positively associated with its } \\
\text { NPD efficiency }\end{array}$ & + & Not Supported \\
\hline 4. & $\begin{array}{l}\mathrm{H}_{2 \mathrm{a}} \text { : A firm's customer orientation is positively associated with its NPD } \\
\text { creativity }\end{array}$ & + & $\underline{\text { Refuted }}$ \\
\hline 5. & $\begin{array}{l}\mathrm{H}_{2 \mathrm{~b}} \text { : A firm's competitor orientation is positively associated with its NPD } \\
\text { creativity }\end{array}$ & + & Supported \\
\hline 6. & $\begin{array}{l}\mathrm{H}_{2 \mathrm{c}} \text { : A firm's interdepartmental coordination is positively associated with its } \\
\text { NPD creativity }\end{array}$ & + & Supported \\
\hline 7. & $\begin{array}{l}\mathrm{H}_{3 \mathrm{a}} \text { : The higher a firm's customer orientation, the higher is the level of its } \\
\text { vision trap }\end{array}$ & + & Not Supported \\
\hline 8. & $\begin{array}{l}\mathrm{H}_{3 \mathrm{~b}} \text { : The higher a firm's customer orientation, the higher is the level of its } \\
\text { technology trap }\end{array}$ & + & Not Supported \\
\hline 9. & $\begin{array}{l}\mathrm{H}_{3 \mathrm{c}} \text { : The higher a firm's customer orientation, the higher is the level of its } \\
\text { routinization trap }\end{array}$ & + & Supported \\
\hline 10. & $\begin{array}{l}\mathrm{H}_{4 \mathrm{a}} \text { : The higher a firm's competitor orientation, the higher is the level of its } \\
\text { vision trap }\end{array}$ & + & Not Supported \\
\hline 11. & $\begin{array}{l}\mathrm{H}_{4 b} \text { : The higher a firm's competitor orientation, The higher is the level of its } \\
\text { technology trap }\end{array}$ & + & Not Supported \\
\hline 12. & $\begin{array}{l}\mathrm{H}_{4 \mathrm{c}} \text { : The higher a firm's competitor orientation, the higher is the level of its } \\
\text { routinization trap }\end{array}$ & + & Not Supported \\
\hline 13. & $\begin{array}{l}\mathrm{H}_{5 \mathrm{a}} \text { : The higher a firm's interdepartmental coordination, the higher is the level } \\
\text { of its vision trap }\end{array}$ & + & Not support \\
\hline 14. & $\begin{array}{l}\mathrm{H}_{5 \mathrm{~b}} \text { : The higher a firm's interdepartmental coordination, the higher is the level } \\
\text { of its technology trap }\end{array}$ & + & Not Supported \\
\hline 15. & $\begin{array}{l}\mathrm{H}_{5 \mathrm{c}} \text { : The higher a firm's interdepartmental orientation, the higher is the level } \\
\text { of its routinization trap }\end{array}$ & + & Not Supported \\
\hline 16. & $\begin{array}{l}\mathrm{H}_{6 \mathrm{a}} \text { : The level of vision trap in a firm's NPD process is positively associated } \\
\text { with its NPD efficiency }\end{array}$ & - & Not Supported \\
\hline 17. & $\begin{array}{l}\mathrm{H}_{6 \mathrm{~b}} \text { : The level of technology trap in a firm's NPD process is positively } \\
\text { associated with its NPD efficiency }\end{array}$ & - & Not Supported \\
\hline 18. & $\begin{array}{l}\mathrm{H}_{6 c} \text { : The level of routinization trap in a firm's NPD process is positively } \\
\text { associated with its NPD efficiency }\end{array}$ & - & Supported \\
\hline 19. & $\begin{array}{l}\mathrm{H}_{7 \mathrm{a}} \text { : The level of vision trap in a firm's NPD process is negatively associated } \\
\text { with its NPD creativity }\end{array}$ & + & Supported \\
\hline 20. & $\begin{array}{l}\mathrm{H}_{7 \mathrm{~b}} \text { : The level of technology trap in a firm's NPD process is negatively } \\
\text { associated with its NPD creativity }\end{array}$ & + & Not Supported \\
\hline 21. & $\begin{array}{l}\mathrm{H}_{7 \mathrm{c}} \text { : The level of routinization trap in a firm's NPD process is negatively } \\
\text { associated with its NPD creativity }\end{array}$ & + & $\underline{\text { Refuted }}$ \\
\hline 22. & $\mathrm{H}_{8 \mathrm{a}}$ : The higher a firm's EO, the lower is the level of its vision trap & - & Not supported \\
\hline 23. & $\mathrm{H}_{8 \mathrm{~b}}$ : The higher a firm's EO, the lower is the level of its technology trap & - & Refuted \\
\hline 24. & $\begin{array}{l}\mathrm{H}_{8 \mathrm{c}} \text { : The higher a firm's EO, the lower is the level of routinization trap in its } \\
\text { NPD }\end{array}$ & - & Not Supported \\
\hline 25. & $\begin{array}{l}\mathrm{H}_{9 \mathrm{a}} \text { : A firm's EO weakens the positive relationship between its MO and } \\
\text { vision trap in its NPD process }\end{array}$ & - & Not Supported \\
\hline 26. & $\begin{array}{l}\mathrm{H}_{9 b} \text { : A firm's EO weakens the positive relationship between its MO and } \\
\text { technology trap in its NPD process }\end{array}$ & - & Supported \\
\hline 27. & $\mathrm{H}_{9 \mathrm{c}}$ : A firm's EO weakens the positive relationship between its MO and & - & Not Supported \\
\hline
\end{tabular}




\begin{tabular}{|c|l|c|c|}
\hline & routinization trap in its NPD process & & Not supported \\
\hline 28. & $\begin{array}{l}\mathrm{H}_{10 \mathrm{a}}: \text { A firm's network learning is negatively associated with the level of } \\
\text { vision trap in its NPD processes }\end{array}$ & - & Refuted \\
\hline 29. & $\begin{array}{l}\mathrm{H}_{10 \mathrm{~b}}: \text { A firm's network learning is negatively associated with the level of } \\
\text { technology trap in its NPD processes }\end{array}$ & - & $\underline{\text { Refuted }}$ \\
\hline 30. & $\begin{array}{l}\mathrm{H}_{10 \mathrm{c}}: \text { A firm's network learning is negatively associated with the level of } \\
\text { routinization trap in its NPD processes }\end{array}$ & - & Not supported \\
\hline 31. & $\begin{array}{l}\mathrm{H}_{11 \mathrm{a}}: \text { A firm's network learning weakens the positive relationship between its } \\
\text { MO and vision trap in its NPD processes }\end{array}$ & - & $\underline{\text { Refuted }}$ \\
\hline 32. & $\begin{array}{l}\mathrm{H}_{11 \mathrm{~b}}: \text { A firm's network learning weakens the positive relationship between its } \\
\text { MO and technology trap in its NPD processes }\end{array}$ & - & Not Supported \\
\hline 33. & $\begin{array}{l}\mathrm{H}_{11 \mathrm{c}}: \text { A firm's network learning weakens the positive relationship between its } \\
\text { MO and routinization trap in its NPD processes }\end{array}$ & - & \\
\hline
\end{tabular}

\subsubsection{Discussion of Results: Direct Relationships $\left(\mathrm{H}_{1 a-c}-\mathrm{H}_{7 a-c}\right)$}

As indicated previously, according to the capability-rigidity theory of Leonard-Barton (1992), MO as a capability can enhance incremental NPD and NPD efficiency while at the same time inhibiting radical NPD and new product creativity by facilitating the creation of competency traps. Little empirical evidence is available to test this theory and framework. This study attempts to test this capability-rigidity theory.

$\mathrm{H}_{\mathrm{a}-\mathrm{c}}$ state that three components of $\mathrm{MO}$ (customer orientation, competitor orientation, and interdepartmental coordination) are positively related to NPD efficiency. The results only partially support $\mathrm{H}_{1 b}$. Contrary to expectations, customer orientation and interdepartmental coordination have no significant relationship with NPD efficiency $\left(\mathrm{H}_{1 \mathrm{a}}\right.$, $\mathrm{H}_{1 \mathrm{c}}$ ). But the data suggest that competitor orientation is positively related to NPD speed $\left(\mathrm{H}_{1 \mathrm{~b} 1}\right)$ but not to NPD resource efficiency $\left(\mathrm{H}_{1 \mathrm{~b} 2}\right)$. Therefore, highly competitor-oriented firms may be able to develop new products more quickly than low competitor-oriented firms because their knowledge about competitors facilitates the NPD search.

$\mathrm{H}_{2 \mathrm{a}-\mathrm{c}}$ state that three components of $\mathrm{MO}$ (customer orientation, competitor orientation, and interdepartmental coordination) are positively related to new product creativity. The results refute $\mathrm{H}_{2 \mathrm{a}}$ but support $\mathrm{H}_{2 \mathrm{~b}}$ and $\mathrm{H}_{2 \mathrm{c}}$. Contrary to expectations, customer 
orientation is negatively related to new product creativity $\left(\mathrm{H}_{2 \mathrm{a}}\right)$. These findings do not support von Hippel's (1986) leader-user theory but are consistent with the view of Christensen and Bower (1996) and with the results of Im and Workman (2004). Consistent with expectations, competitor orientation is positively related to new product creativity. Highly competitor-oriented firms are more likely to create new products that are different from those of their competitors (Im and Workman 2004). Consistent with expectations, interdepartmental coordination is positively related to new product creativity. Firms with interdepartmental coordination are more likely to generate novel new product ideas than are firms without interdepartmental coordination, because of the heterogeneity of viewpoints from different functions.

$\mathrm{H}_{3 \mathrm{a}-\mathrm{c}}$ attempt to check whether customer orientation leads to three types of competency traps (vision, technology, and routinization). $\mathrm{H}_{4 \mathrm{a}-\mathrm{c}}$ attempt to check whether competitor orientation leads to three types of competency traps (vision, technology, and routinization). $\mathrm{H}_{5 \mathrm{a}-\mathrm{c}}$ attempt to check whether interdepartmental coordination leads to three types of competency traps (vision, technology, and routinization). The results reject all the hypotheses except for $\mathrm{H}_{3 \mathrm{c}}$ : customer orientation may lead to routinization traps. An explanation for these results may be that the relationship between MO and competency traps is indirect rather than direct. It is possible that $\mathrm{MO}$ and competency traps coexist in firms, interact with each other, and then impact new product innovation performance. However, the findings suggest that customer orientation does have direct relationship with routinization traps. A high customer orientation may lead firms to follow standardized and formalized routines and procedures. 
As the proposed framework indicates, the competency traps represent a type of inertia and rigidity in the organizational learning. Competency traps may encourage exploitation learning (NPD efficiency) and discourage exploration learning (new product creativity). $\mathrm{H}_{6 \mathrm{a}-\mathrm{c}}$ attempt to check whether three different types of competency traps (vision, technology, and routinization) are positively associated with NPD efficiency. The data support only $\mathrm{H}_{6 \mathrm{c}}$ and reject $\mathrm{H}_{6 a}$ and $\mathrm{H}_{6 b}$. The findings suggest that routinization trap encourages experiential learning, which shortens NPD speed and enables the firm to use its resources very productively. Therefore, routinization trap is positively associated with NPD efficiency.

$\mathrm{H}_{7 \mathrm{a}-\mathrm{c}}$ attempt to check whether three different types of competency traps (vision, technology, and routinization) are negatively associated with NPD creativity. According to this data set, $\mathrm{H}_{7 \mathrm{a}}$ is supported, $\mathrm{H}_{7 \mathrm{~b}}$ is rejected, and $\mathrm{H}_{7 \mathrm{c}}$ is refuted. Therefore, vision trap discourages exploration learning and is negatively associated with NPD creativity. Contrary to expectations, technology trap has no relationship with new product creativity. In addition, routinization trap encourages rather than discourages exploration learning: it is positively related to new product creativity.

To summarize these results above, the capability-rigidity theory of Leonard-Barton (1992) is only partial supported. The positive effect of MO on NPD is only supported by the positive relationship between competitor orientation and NPD speed. Contrary to expectations, $\mathrm{MO}$ also has positive rather than negative effects on new product creativity: competitor orientation and interdepartmental coordination are positively related to new product creativity. The negative effect of MO on NPD is only supported by the negative relationship between customer orientation and new product creativity. 
Furthermore, I predicted that the negative effect of MO on new product creativity derived from the rigidity-competency traps generated by MO. In other words, MO causes competency traps, and competency traps reduce new product creativity. According to the results, among the three competency traps, only customer orientation creates routinization traps. Contrary to expectations, routinization traps increase rather than decrease new product creativity. In addition, routinization traps also increase NPD speed and NPD resource efficiency. Although vision traps decrease new product creativity, there is no link between vision trap and any of the dimensions of MO.

Therefore, it is difficult to say that the reason MO inhibits new product creativity is because of competency traps. Not all competency traps are harmful for new product innovation. In some situations, firms may benefit from some forms of rigidity, such as routinization traps.

\subsubsection{Discussion of Results: Moderating Relationships $\left(\mathrm{H}_{8 a-c}-\mathrm{H}_{11 a-c}\right)$}

As indicated previously, organizational learning theory and DC theory suggest that complementary capabilities to $\mathrm{MO}$ are required in order to reduce the rigidity and increase new product innovation performance.

$\mathrm{H}_{8 \mathrm{a}-\mathrm{c}}$ state that EO may reduce three different types of competency traps (vision, technology, and routinization). The results only suggest that EO is significantly related to technology traps $\left(\mathrm{H}_{8 \mathrm{~b}}\right)$. However, this relationship is positive rather than negative.

$\mathrm{H}_{9 \mathrm{abc}}$ state that EO may weaken the relationship between MO and three different types of competency traps (vision, technology, and routinization). The results suggest that EO only weakens the relationship between $\mathrm{MO}$ and technology trap $\left(\mathrm{H}_{9 b}\right)$. 
Combining $\mathrm{H}_{8 \mathrm{~b}}$ and $\mathrm{H}_{9 \mathrm{~b}}$, I expected that a firm's EO weakens the positive relationship between its MO and technology traps in its NPD process. But the results show that a firm's EO strengthens the negative relationship between its MO and technology traps in its NPD process. To facilitate interpretation, this interaction was plotted in Figure 5.3. As shown in Figure 5.3, MO has a stronger negative effect on technology traps in high-entrepreneurialoriented firms than in low-entrepreneurial-oriented firms. In low-market-oriented firms, entrepreneurial culture does not have much influence on firms' technology decisions. But in high-market-oriented firms, entrepreneurial culture does influence firms' technology decisions. When the high-market-oriented firms employ high entrepreneurial culture, they are less likely to fall into technology traps and stick with mature and familiar technology. When the high-market-oriented firms employ low entrepreneurial culture, they are more likely to fall into technology traps and stick with mature and familiar technology.

Therefore, consistent with expectations, EO is the remedy for market-oriented firms to reduce their level of technology traps. This finding demonstrates the importance of entrepreneurship in business practice. Entrepreneurial activities can provide market-oriented firms an additional ability to recognize new opportunities and to create unique perspectives, which reduces rigidity and sustains innovation performance.

$\mathrm{H}_{10 \mathrm{a}-\mathrm{c}}$ state that network learning may reduce three different types of competency traps (vision, technology, and routinization). Contrary to expectations, the results show that network learning is positively rather than negatively related to technology traps and routinization traps $\left(\mathrm{H}_{10 \mathrm{~b}}, \mathrm{H}_{10 \mathrm{c}}\right)$.

$\mathrm{H}_{11 \mathrm{a}-\mathrm{c}}$ state that network learning may weaken the relationship between $\mathrm{MO}$ and three different types of competency traps (vision, technology, and routinization). Contrary to 


\section{Figure 5.3 Interaction Between MO and EO on Technology Traps}

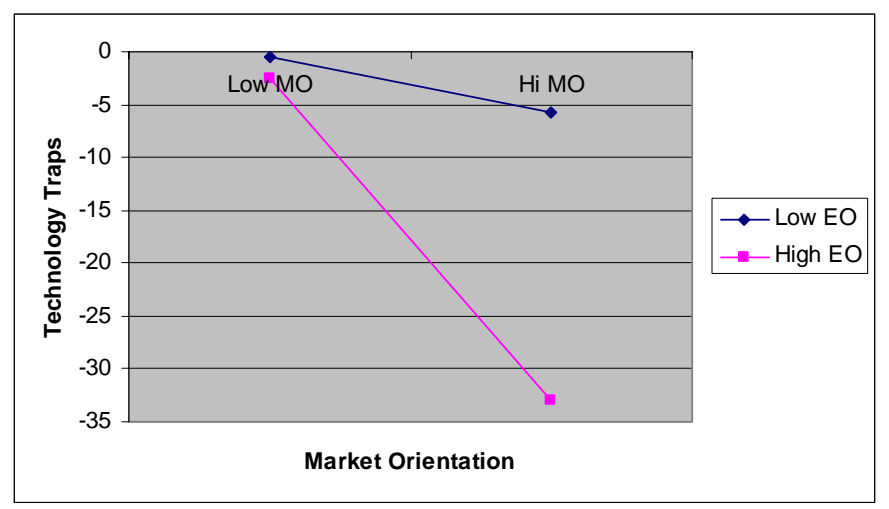

expectations, the results show that network learning fosters rather than weakens the relationship between $\mathrm{MO}$ and technology traps as well as routinization traps $\left(\mathrm{H}_{11 \mathrm{~b}}\right)$.

In combining $\mathrm{H}_{10 \mathrm{~b}}$ and $\mathrm{H}_{11 \mathrm{~b}}$, I expected that a firm's network learning weakens the positive relationship between its MO and technology traps in its NPD processes. But the results show that that a firm's network learning strengthens the positive relationship between its MO and technology traps in its NPD processes. Figure 5.4 illustrates this interaction, indicating that MO has a stronger positive effect on the level of technology trap when network learning is high rather than low. Network learning does not much influence the level of technology traps in low-market-oriented firms. But network learning does make a big difference for high-market-oriented firms. When high-market-oriented firms employ high network learning, they are more likely to fall into technology traps and less likely to use new emerging technologies. When high-market-oriented firms employ low network learning, they are less likely to fall into technology traps and stick with mature and familiar technology. Therefore, contrary to expectations, network learning cannot reduce the level of technology 
traps for market-oriented firms. This finding suggests that network learning may still create groupthink for firms at the industry level. Industry "recipes" generated by network learning might guide market-oriented firms toward sticking with mature and familiar technology.

Figure 5.4 Interaction Between Market Orientation and Network Learning on Technology Traps

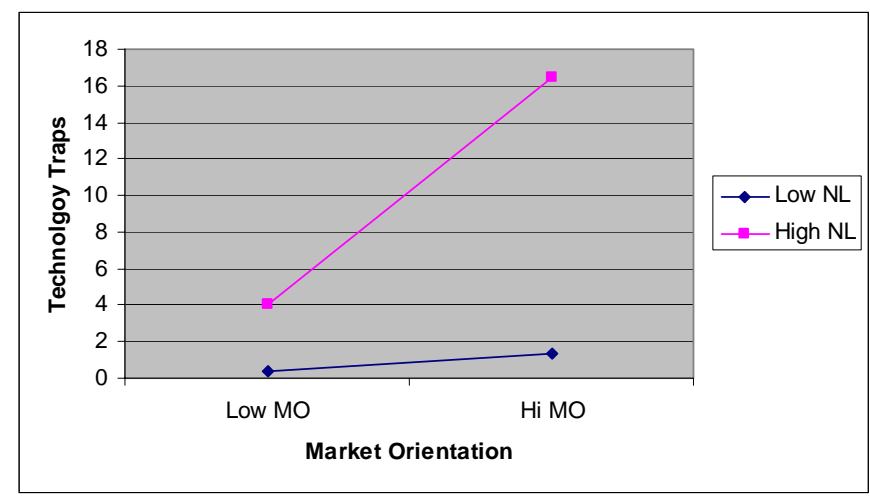




\section{CHAPTER 6: IMPLICATIONS, LIMITATIONS, CONCLUSIONS}

This chapter is the final chapter. It reviews the study's potential implications in light of the research questions and the theoretical models presented in chapters 1 and 2, respectively. It also addresses the limitations of the current study and offers directions for future research. I review the objectives, research questions, and contributions of the study before offering the implications.

\subsection{Review of the Research Questions in the Study}

Learning traps are a dangerous zone that firms should not step into. Competency traps, one type of learning trap, lead firms to unconsciously fall into a vicious cycle of adherence to inferior routines and denial of the need for change (Fiol and Lyles 1985; King and West 2002; Levinthal and March 1993; Levitt and March 1988). Both the marketing and the management literatures call for an integrated conceptual framework for identifying competency traps, their antecedents, and the consequences for firms' innovation outcomes. This dissertation attempts to fill this important research gap with its three objectives. The first objective is to conceptualize competency traps and develop new scales for competency traps. The second objective is to investigate the relationship between MO, competency traps, and new product innovation in the capability-rigidity theory framework. The third objective is to 
examine whether the relationship between MO and competency traps depends on EO and network learning, as suggested by DC theory.

On the basis of these objectives, this study aims to answer three questions.

What are competency traps and how to define and measure them? Although the notion of competency traps is important for both academics and practitioners, little is known about how to conceptualize and operationalize competency traps. The development of a competency-trap scale should enable firms to identify competency traps and stimulate muchneeded empirical research. This study classifies competency traps into three types: (1) vision, (2) technology, and (3) routinization. The scales developed in this study for vision, technology, and routinization traps have demonstrated reasonably good validities and reliabilities.

What kind of relationship exists among MO, competency traps, and new product innovation? Why and how does a firm competence such as MO lead to competency traps? What are the consequences of competency traps for new product innovation? Marketing and management scholars have debated the role of a firm's customer orientation in innovation. Christensen and Bower (1996) suggest that close customer ties deter product and service innovation. A customer orientation may contribute to imitation and to more conservative NPD (e.g., Bennett and Cooper 1979, 1981). In contrast, Slater and Narver (1998) argue that a marketoriented philosophy (customer orientation, competitor orientation, and interfunctional coordination) consists of more than being customer led and is essential to success in terms of NPD. 
The findings of this study answered the debate in the following way: consistent with the suggestions of Christensen and Bower (1996), a firm's customer orientation is negatively associated with its NPD creativity. Consistent with Slater and Narver's (1998) arguments that market orientation goes beyond being customer led, a firm's competitor orientation and interfunctional coordination are positively associated with its NPD creativity. In addition, a firm's competitor orientation is positively associated with its NPD resource efficiency.

Capability-rigidity theory suggests that $\mathrm{MO}$, as a capability or a learning mechanism, may create competency traps and decrease new product creativity while directly increasing NPD efficiency. The findings of this study showed that a firm's customer orientation does create routinization traps. However, contrary to expectations, not all competency traps are harmful for NPD. Although vision traps in a firm's NPD process are negatively associated with NPD creativity, routinization traps in a firm's NPD process are positively associated with its NPD creativity and NPD resource efficiency.

How can firms reduce the occurrence and negative consequences of competency traps? Why and how does this work? On the basis of organizational learning theory and DC theory, EO and network orientation are suggested as complements to $\mathrm{MO}$ to reduce competency traps and to enhance creativity in new product innovation. According to the results of this study, consistent with predictions, EO is more likely to help high-market-oriented firms rather than low-market-oriented firms reduce technology traps. However, contrary to expectations, network learning is more likely to lead high-market-oriented firms rather than low-marketoriented firms to increase rather than reduce the level of technology traps.

In the subsequent section, I discuss the theoretical and managerial implications of the findings of this study in detail. 


\subsection{Implications for the Literature}

This dissertation attempts to make significant contributions to the marketing and the management literatures and practices in five ways.

The major contribution of this study is the first step toward conceptualizing and developing scales for competency traps. Although the notion of competency traps was suggested by the management literature more than a decade ago, the concept remains undeveloped. The new scales conceptualized and developed in this dissertation provide a foundation for future research on competency traps. Thus, this research may stimulate muchneeded empirical research in the future.

Second, the findings of this dissertation include empirical evidence that contributes to the debate about whether customer power has adverse effect on radical innovation and new product creativity. The findings support the work of Christensen and Bower (1996) and partially support the work of Slater and Narver $(1998,1999)$. Consistent with the work of Christensen and Bower (1996), a firm that only has a focus customer orientation is harmful to new product creativity. Consistent with the suggestions of Slater and Narver $(1998,1999)$, competitor orientation and interfunctional coordination are positively associated with NPD creativity. A firm's competitor orientation is positively associated with its NPD resource efficiency. The conflict effects from different dimensions of MO (customer orientation, competitor orientation, and interfunctional coordination) on new product creativity have confirmed why previous literature has documented mixed results in the MO-NPP relationship. 
Third, this study advances understanding of competency traps. Not all types of competency traps are definitely harmful to NPD. Although vision traps in a firm's NPD process are negatively associated with NPD creativity, routinization traps in a firm's NPD process are positively associated with NPD creativity and NPD resource efficiency.

Fourth, the findings of this study provide some empirical evidence for capabilityrigidity theory. Capability-rigidity theory suggests that MO may enhance and inhibit NPD at the same time. According to the results, some dimensions of MO do enhance NPD. Competitor orientation and cross-functional coordination enhance new product creativity, and competitor orientation also enhances NPD speed. Some dimensions of MO do inhibit NPD. Customer orientation inhibits new product creativity.

How does MO inhibit and enhance NPD at the same time? To advance capabilityrigidity theory, this study hypothesizes that competency traps are the rigidity created by MO, and in return competency traps reduce new product creativity. However, the results do not support this hypothesized framework. According to the results, customer orientation creates routinization trap. But contrary to expectations, routinization traps enhance, not reduce, new product creativity, NPD speed, and NPD resource efficiency. Although vision traps are negatively associated with NPD creativity, there is no link between any dimensions of MO and vision trap.

Therefore, the results of this study demonstrate a much more complex relationship than what the theory and framework predict. These complex relationships not only increase understanding but also provide an opportunity for future research to advance capabilityrigidity theory. 
Fifth, the study found that EO and network learning play moderating roles in the relationship between $\mathrm{MO}$ and technology trap. Entrepreneurial orientation is more likely to reduce technology traps in high-market-oriented firms than in low-market-oriented firms. However, contrary to expectations, network learning is more likely to create technology traps in high-market-oriented firms than in low-market-oriented firms. Thus, EO but not network orientation is the remedy for technology traps.

\subsection{Implications for Practitioners}

The findings of this study should help managers better understand how to identify and manage the level of competency traps in order to improve NPP. This study has four managerial implications for managers and practitioners.

First, the new scale developed in this dissertation may help managers diagnose the existence and level of competency traps.

Second, it is dangerous for firms to be only customer oriented. It is important to be competitor oriented and have interfunctional coordination in order to have a high level of new product creativity.

Third, managers should be aware that different types of competency traps may have different effects on new product innovation. Vision traps may harm new product creativity. However, routinization trap as a form of rigidity may help a firm's NPD process in terms of new product creativity and NPD efficiency. Therefore, firms should take advantage of good competency traps, such as routinization, and reduce bad competency traps, such as vision, in order to improve their new product innovation rate. 
Fourth, managers in high-market-oriented firms should employ EO to reduce technology traps. However, managers in high-market-oriented firms should not be network oriented, because network learning may still lead to groupthink and make the firms stick with industry norms.

\subsection{Limitations and Directions for Future Research}

Although this study provides some meaningful results for research and practice, there are several limitations. These limitations might threaten the internal and external validity of the research, but they also provide opportunities for future research:

First, the sample size (113) in this study is relatively small, which may limit the generalizability of the findings. In addition, competency traps as a type of rigidities may occur in all kinds of contexts beyond marketing and NPD. In order to prove the generalizability of these new constructs, it is necessary to test these constructs in other functions and contexts of a firm, such as management, manufacturing, operations, finance, administration, and service. Furthermore, this study is conducted in China, which may limit the extent to which the results can be applied to firms in other countries with different cultural contexts. Thus, future studies should use larger samples in order to gain more confidence in these results. Also, a clear conclusion can be drawn if this study would be replicated with other samples in other functional domains and different countries.

Second, the use of an availability-sampling method can easily be challenged for its generalizability. The study adopted availability sampling rather than random sampling, which may present some biases in the data. The companies that were willing to participate in the research may be different from those that were not willing to participate. Therefore, the 
representativeness of this nonrandom sample is in doubt. Future studies should attempt to study this content with randomized samples.

Third, the cross-sectional approach may not lead to effective conclusions regarding causality. Lack of sufficient causality may make it difficult to apply the conclusions to all industries. Although the current research accessed firms from several industries, the limited sample size did not allow for industry comparisons. Furthermore, because MO, competency traps, and new product innovation are all dynamic factors, it is difficult to use the crosssectional data to reflect ongoing transformations in relationships. Therefore, it is important to incorporate longitudinal research designs in the future to enable better capturing of the dynamism of the constructs and better understanding of the learning process in NPD.

Fourth, this study originally aimed to have one marketing manager and one R\&D manager from each firm in order to avoid various biases. Unfortunately, although the actual sample frame (302 usable questionnaires from 151 firms) had two respondents from each firm, most respondents were marketing managers (158 marketing managers and only 34 R\&D managers). The rest of the respondents are CEOs and managers from manufacturing, finance and accounting, and administrative departments. As a result, the original plan could not be implemented by this sample frame. Therefore, only 113 marketing managers' questionnaires were selected to test the hypotheses. Future studies should attempt to collect data from multiple respondents, which allows for reliability checks of data and avoids various biases, such as position, vested interests, and common method.

Future research should further conceptualize other important types of learning traps and develop new scales for them. For example, power trap occurs when organizations use their power to impose environments, which likely results in an atrophied ability to respond to 
change in the long run. Failure trap occurs when organizations are turned into frenzies of experimentation, change, and innovation by a dynamic of failure. New ideas and technologies fail and are replaced by other new ideas and technologies, which in turn fail (Levinthal and March 1993).

Moreover, further study is needed to investigate other important mediators and moderators in the relationship among MO, competency traps, and NPD innovation, such as competitive behavior versus collaborating behavior and output control versus process control. For example, competitive behavior may help market-oriented firms address the rigidity generated by competency traps and increase NPD creativity, while collaborating behavior may foster competency traps in market-oriented firms and decrease NPD creativity.

Furthermore, because of the lack of mature measurements for radical innovation and incremental innovation, this research indirectly studied the relationship between $\mathrm{MO}$ and NPD creativity and efficiency. Future studies should attempt to search for or develop measurements for radical and incremental innovation and investigate the direct evidence for the debate.

\subsection{Conclusions}

The main purpose of this study was to conceptualize and develop scales for competency traps, to obtain empirical evidence in the debate between the management and marketing literatures as to the relationship between $\mathrm{MO}$ and innovation, and to understand the role of competency traps in the relationship between MO and new product innovation. 
This study used data from 46 MBA students for pretest and 113 marketing managers in high-tech industry zone in China for the final study. Structural equation modeling and reliability tests were used for data analysis.

Three types of competency traps were conceptualized in this study: (1) vision, (2) technology, and (3) routinization. The newly developed scales demonstrated reasonably good validity and reliability.

Moreover, the data showed that a firm's customer orientation is negatively associated with NPD creativity, but its competitor orientation and interdepartmental coordination are positively associated with NPD creativity. In addition, a firm's competitor orientation is also positively associated with NPD resource efficiency.

Furthermore, the findings indicated that customer orientation may lead to routinization trap. Among the three types of competency traps, only the level of vision trap in a firm's NPD process is negatively associated with its NPD creativity. The level of routinization trap in a firm's NPD process is positively associated with its new product creativity and NPD efficiency. No significant, direct relationship was found in the relationship between technology trap and new product innovation.

The relationship between technology trap and new product innovation is indirect and moderated by EO and network learning. Entrepreneurial orientation, playing a positive moderating role, is more likely to help high-market-oriented firms rather than low-marketoriented firms reduce technology traps. However, network learning, playing a negative moderating role, is more likely to lead high-market-oriented firms rather than low-marketoriented firms increase the level of technology traps. 
This study is a pioneering research attempt to explore the existence and role of competency traps in the relationship between $\mathrm{MO}$ and new product innovation. This study also provides insights into the debate between the marketing and management literatures. In particular, this study investigates how to help firms reduce competency traps and improve new product innovation. Thus, it contributes to the marketing and management literatures by studying the relationship among rigidity-competency traps, $\mathrm{MO}$, and new product innovation. Although some useful results have been discovered, the findings should be considered tentative, given the issues examined and the limitations of the study. Future studies are needed to refine this work and to provide additional insights into the literature and practice. 


\section{APPENDIX}

\section{A SURVEY OF NEW PRODUCT DEVELPMENT}

We'd like to ask you to help us with this survey of new product development practices. Your complete response is very important to the accuracy of the research. The survey uses a fixed-response format so that you will be able to complete it easily and quickly-less than $\mathbf{2 0}$ minutes. This is not a "test" and there are no correct or incorrect answers. Companies perform various activities in different ways, and no one way is better than others. We simply want your opinion based on your knowledge and experience of practice in your firm. To ensure reliable and valid measures, some of the items you see may appear similar, while others look very different from one another. It is important to respond to every item, even if the wording for a question is not exactly what you might have used. Simply read each question carefully and then circle the response that best matches your opinion. In answering the questions in this survey, please focus on the new products you have developed and launched over the past 12 months.

\section{SECTION I: GENERAL PRACTICES IN YOUR COMPANY}

\begin{tabular}{|c|c|c|c|c|c|c|c|}
\hline $\begin{array}{l}\text { Please indicate to what extent you agree with the following statements about } \\
\text { your company: }\end{array}$ & \multicolumn{3}{|c|}{$\begin{array}{l}\text { Not } \\
\text { At All }\end{array}$} & & \multicolumn{3}{|c|}{$\begin{array}{l}\text { Great } \\
\text { Extent }\end{array}$} \\
\hline $\begin{array}{l}\text { We constantly monitor our level of commitment and orientation to serving } \\
\text { customers needs }\end{array}$ & 1 & 2 & 3 & 4 & 5 & 6 & 7 \\
\hline $\begin{array}{l}\text { Our business strategies are driven by our beliefs about how we can create greater } \\
\text { value for our customers }\end{array}$ & 1 & 2 & 3 & 4 & 5 & 6 & 7 \\
\hline $\begin{array}{l}\text { Our strategy for competitive advantage is based on our understanding of customers } \\
\text { needs }\end{array}$ & 1 & 2 & 3 & 4 & 5 & 6 & 7 \\
\hline Our business objectives are driven primarily by customer satisfaction & 1 & 2 & 3 & 4 & 5 & 6 & 7 \\
\hline We measure customer satisfaction systematically and frequently & 1 & 2 & 3 & 4 & 5 & 6 & 7 \\
\hline We give close attention to after-sales service & 1 & 2 & 3 & 4 & 5 & 6 & 7 \\
\hline $\begin{array}{l}\text { Our salespeople regularly share information within our business concerning } \\
\text { competitor strategies }\end{array}$ & 1 & 2 & 3 & 4 & 5 & 6 & 7 \\
\hline We rapidly respond to competitive actions that threaten us & 1 & 2 & 3 & 4 & 5 & 6 & 7 \\
\hline Top managers regularly discuss competitors' strengths and strategies & 1 & 2 & 3 & 4 & 5 & 6 & 7 \\
\hline We target customers where we have opportunities for competitive advantage & 1 & 2 & 3 & 4 & 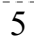 & 6 & 7 \\
\hline $\begin{array}{l}\text { Our top managers from every function regularly visit our current and prospective } \\
\text { customers }\end{array}$ & 1 & 2 & 3 & 4 & 5 & 6 & 7 \\
\hline $\begin{array}{l}\text { We freely communicate information about our successful and unsuccessful } \\
\text { customer experiences across all business functions }\end{array}$ & 1 & 2 & 3 & & & 6 & 7 \\
\hline $\begin{array}{l}\text { All of our business functions (e.g., marketing/sales, manufacturing, R\&D, } \\
\text { finance/accounting, etc) are integrated in serving the needs of our target markets. }\end{array}$ & 1 & 2 & 3 & 4 & 5 & 6 & 7 \\
\hline $\begin{array}{l}\text { All of our managers understand how everyone in our business can contribute to } \\
\text { creating customer value }\end{array}$ & 1 & 2 & 3 & 4 & 5 & 6 & 7 \\
\hline We share resources with other business units & 1 & 2 & 5 & & & 6 & 7 \\
\hline
\end{tabular}

To what extent do the following statements describe your company?

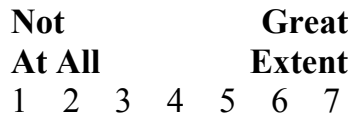

When it comes to problem solving, we value creative new solutions more than the conventional wisdom 
Top managers here encourage the development of innovative marketing strategies, $\quad \begin{array}{lllllllll}1 & 2 & 3 & 4 & 5 & 6 & 7\end{array}$ knowing well that some will fail

Relative to our competitors, our company has a higher ability to implement experimentation and original approaches to problems

Relative to our competitors, our company has higher levels of innovation

We value leadership initiatives for change more highly than risk-reducing

management process

Top managers in this business unit do not like to "play it safe"

$\begin{array}{lllllllllll}\text { Top managers around here are happy to implement plans even if they are uncertain } & 1 & 2 & 3 & 4 & 5 & 6 & 7\end{array}$ that they will work

Relative to our competitors, our company has a strong proclivity for high-risk goals $\quad 1 \quad \begin{array}{lllllll}2 & 2 & 4 & 5 & 6 & 7\end{array}$ with chances of high returns

$\begin{array}{lllllllllllllll}\text { Relative to our competitors, our company has a higher propensity to take risks } & 1 & 2 & 3 & 4 & 6 & 7\end{array}$

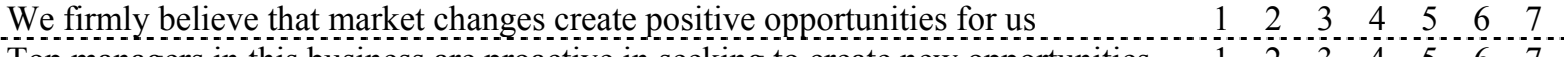

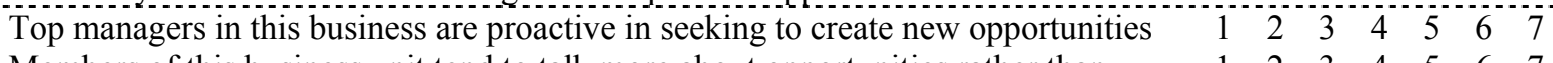

Members of this business unit tend to talk more about opportunities rather than $\quad \begin{array}{llllllll} & 1 & 2 & 3 & 4 & 5 & 6 & 7\end{array}$

problems

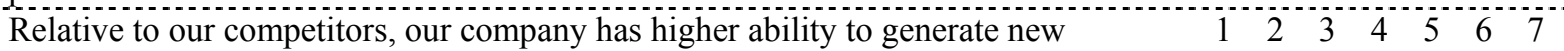
opportunities

To what extent do you agree with the following statements about your company's relationships with outside companies and organizations (e.g., suppliers, distributors, consultants, retailers, banks, government and

\section{Strongly \\ Strongly} Disagree

Agree university contacts, technology search firms, etc.).

We have strong relationships with companies and organizations outside of our industry

We benefit from close contacts with companies and organizations outside of our industry

We have learned a lot from interactions with companies and organizations outside $\quad \begin{array}{lllllll}1 & 2 & 3 & 4 & 5 & 6 & 7\end{array}$ of our industry

We have gained significant knowledge from companies and organizations outside of our industry

We have partners from a wide variety of different industries $\begin{array}{lllllll}1 & 2 & 3 & 4 & 5 & 6 & 7\end{array}$

$\begin{array}{lllllll}1 & 2 & 3 & 4 & 5 & 6 & 7\end{array}$

123345567

$\begin{array}{lllllll}1 & 2 & 3 & 4 & 5 & 6 & 7\end{array}$

\section{SECTION II: NEW PRODUCT DEVELOPMENT (NPD) PRACTICES}

\begin{tabular}{|c|c|c|c|c|c|}
\hline $\begin{array}{l}\text { In your new product development }(\mathrm{NPD}) \text { efforts over the past } 12 \text { months, how } \\
\text { much insight or knowledge has your company gained from your relationships }\end{array}$ & $\begin{array}{l}\text { None } \\
\text { At All }\end{array}$ & & & & $\begin{array}{l}\text { Great } \\
\text { nount }\end{array}$ \\
\hline Our suppliers & 123 & 3 & & & 67 \\
\hline Our distributors & 123 & 3 & & & 67 \\
\hline Our consultants & 123 & 3 & 4 & 5 & 67 \\
\hline Our retailers & 123 & 3 & 4 & 5 & 67 \\
\hline Our contacts in universities and government & 123 & 3 & $t$ & 5 & 67 \\
\hline Companies outside of our industry & 123 & & & & 67 \\
\hline $\begin{array}{l}\text { Please think about how your company develops new products, and indicate to } \\
\text { what extent you agree with the following statements: }\end{array}$ & \multicolumn{3}{|c|}{$\begin{array}{l}\text { Strongly } \\
\text { Disagree }\end{array}$} & \multicolumn{2}{|c|}{$\begin{array}{r}\text { Strongly } \\
\text { Agree }\end{array}$} \\
\hline $\begin{array}{l}\text { Our confidence in our NPD process is based on its past success rather than its } \\
\text { current performance }\end{array}$ & 123 & & & & 67 \\
\hline $\begin{array}{l}\text { We believe that the past success of our NPD process makes it the best approach for } \\
\text { the future }\end{array}$ & 123 & 3 & & & 67 \\
\hline
\end{tabular}




$\begin{aligned} & \text { Because of its past success people tend to ignore current weaknesses in our NPD } \\ & \text { approach }\end{aligned}$
$\begin{aligned} & \text { Our pride in the past success of our NPD processes blinds us to opportunities for } \\ & \text { improvement }\end{aligned}$
$\begin{aligned} & \text { Despite contrary indications, people still believe our NPD approach is better than } \\ & \text { that of our rivals }\end{aligned}$
$\begin{aligned} & \text { The past success of our NPD process inhibits attempts to experiment with new } \\ & \text { approaches }\end{aligned}$

In the new products we have developed over the past year....

...we have incorporated a lot of technology that is new to the industry $\quad \begin{array}{lllllll}1 & 2 & 3 & 4 & 5 & 6 & 7\end{array}$

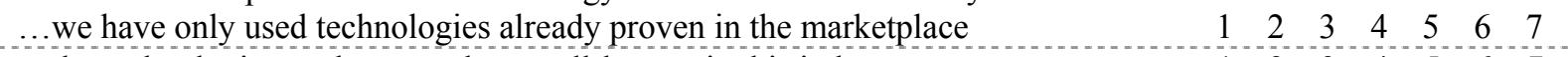

$\begin{array}{llllllll}\text {...the technologies we have used are well-known in this industry } & 1 & 2 & 3 & 4 & 5 & 6 & 7\end{array}$

$\ldots$ we have used tried and tested methods $\quad \begin{array}{lllllll}1 & 2 & 3 & 4 & 5 & 6 & 7\end{array}$

$\begin{array}{lllllllll} & \text {..we have tended to stick with what we know } & 1 & 2 & 3 & 4 & 5 & 6 & 7\end{array}$

...the technologies we have incorporated have all been mature $\quad \begin{array}{lllllll}1 & 2 & 3 & 4 & 5 & 6 & 7\end{array}$

In developing new products...

$\begin{array}{lllllll}\text {...We have well-understood "rules" } & 1 & 2 & 3 & 4 & 5 & 6\end{array}$

$\ldots$ our procedures are highly formalized $\quad \begin{array}{lllllll}1 & 2 & 3 & 4 & 5 & 6 & 7\end{array}$

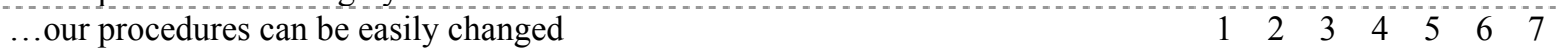

$\ldots$ we never relax our standard procedures $\quad \begin{array}{lllllll}1 & 2 & 3 & 4 & 5 & 6 & 7\end{array}$

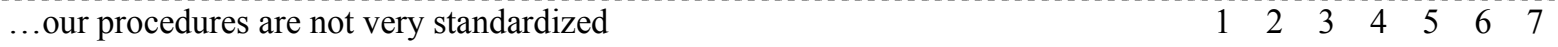

$\begin{array}{llllllll}\text {...we follow formalized procedures } & 1 & 2 & 3 & 4 & 5 & 6 & 7\end{array}$

Now we ask that you switch gears and first examine each of the opposite statements below. For each pair of statements, please circle the number that best indicates your assessment of new product development activities in your company.

We frequently undertake NPD projects $\quad \begin{array}{lllllllll}1 & 2 & 3 & 4 & 5 & 6 & 7 & \text { We usually undertake NPD }\end{array}$ that we are uncertain we can projects that we are certain we can successfully complete

We often develop new product ideas $\begin{array}{llllllll}1 & 2 & 3 & 4 & 5 & 6 & 7 & \text { We only develop new product }\end{array}$

for

emerging or anticipated market needs

Most of our NPD projects require us to

$$
\text { develop }
$$

new knowledge and areas of expertise

We are always experimenting with new

ways of developing new products

We frequently undertake NPD projects that require us to experiment with new ideas that meet existing market needs

$\begin{array}{llllllll}1 & 2 & 3 & 4 & 5 & 6 & 7 & \text { Most of our NPD projects tap our }\end{array}$ existing areas of knowledge and expertise

$\begin{array}{lllllllll}1 & 2 & 3 & 4 & 5 & 6 & 7 & \text { We always use tried and tested }\end{array}$ new product development approaches

$\begin{array}{llllllll}1 & 2 & 3 & 4 & 5 & 6 & 7 & \text { We only undertake NPD projects }\end{array}$ where we can exploit existing technologies technologies

\footnotetext{
Please indicate to what extent you agree with the following statement about your company's new product development:

We support NPD projects even if they could potentially take away from sales of

Strongly Disagree $\begin{array}{lllllll}1 & 2 & 3 & 4 & 5 & 6 & 7\end{array}$ existing products.

We are willing to sacrifices sales of existing products in order to improve sales of new products.

We often develop new products that compete with our existing products.

Our investments in current technologies make switching to new technologies easy.

We rely too much on our current technologies to switch focus to new
} 
technologies.

We are reluctant to cannibalize our investments in our current technologies.

$\begin{array}{lllllll}1 & 2 & 3 & 4 & 5 & 6 & 7\end{array}$

\section{SECTION III: NEW PRODUCT DEVELOPMENT OUTCOMES}

Please rate the extent to which your new products have achieved planned

Not Great

objectives during the first 12 months of their life in the marketplace in terms of: At All Extent

Market share

Sales

$\begin{array}{lllllll}1 & 2 & 3 & 4 & 5 & 6 & 7\end{array}$

Profit margin

Return on investment

$\begin{array}{lllllll}1 & 2 & 3 & 4 & 5 & 6 & 7\end{array}$

$12-3-5-6-7$

Compared with your largest competitor's product(s), to what extent have your new product(s) over the past 12 months been superior in following dimensions:

Reliability: our new products are free of errors compared with the competitor's products

Compatibility: our new products are more compatible with other products than competitor's products

Uniqueness: our product offers unique benefits to customers not provided by

competitors

Productivity: our new products increase a customer's work efficiency more than competitor's products

Ease of use: our new products are easier to learn and use than competitor's products

Not

Great

Functionality: our new products solve problems customers have with competitor products

Quality: Customers perceived the quality as significantly higher than competitor

products

Now we ask that you switch gears and first examine each of the opposite statements below. For each pair of statements

please circle a number that best indicates your assessment of the new products developed by your company over the past 12 months compared to existing products in the marketplace.

\begin{tabular}{rllllllll} 
Dull & 1 & 2 & 3 & 4 & 5 & 6 & 7 & Exciting \\
Fresh & 1 & 2 & 3 & 4 & 5 & 6 & 7 & Routine \\
\hline Conventional & 1 & 2 & 3 & 4 & 5 & 6 & 7 & Unconventional \\
Novel & 1 & 2 & 3 & 4 & 5 & 6 & 7 & Predictable \\
\hline Usual & 1 & 2 & 3 & 4 & 5 & 6 & 7 & Unusual \\
Unique & 1 & 2 & 3 & 4 & 5 & 6 & 7 & Ordinary \\
\hline Commonplace & 1 & 2 & 3 & 4 & 5 & 6 & 7 & Original
\end{tabular}

For each pair of statements below, please circle a number that best indicates your assessment of the speed of the new product development activities in your company over the past 12 months.

$\begin{array}{llllllll}\text { Usually behind our time goals } & 1 & 2 & 3 & 4 & 5 & 6 & 7\end{array}$ Usually ahead of our time goals

Slower than the industry average $\begin{array}{llllllllll}1 & 2 & 3 & 4 & 5 & 6 & 7 & \text { Faster than the industry average }\end{array}$

Much slower than we expected $\quad \begin{array}{lllllllll}1 & 2 & 3 & 4 & 5 & 6 & 7 & \text { Much faster than we expected }\end{array}$

Much slower than our competitors $\begin{array}{llllllllll}1 & 2 & 3 & 4 & 5 & 6 & 7 & \text { Much faster than our competitors }\end{array}$

Please consider your new product development efforts over the past 12 months. For each pair of adjectives below, please circle a number that best indicates your assessment of the resources consumed in new product development.

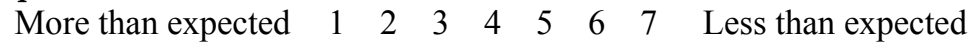

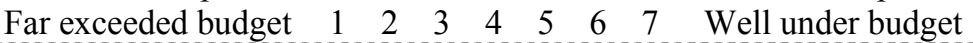


Many resources consumed $1 \begin{array}{llllllll}1 & 2 & 3 & 4 & 5 & 6 & 7 & \text { Few resources consumed }\end{array}$

Exceeding plan $11 \quad 2 \quad 3 \quad 4 \quad 5 \quad 5 \quad 6 \quad 7$ Less than plan

\section{SECTION IV: YOUR FIRM'S MARKETPLACE AND POSITION}

The following set of questions refers to your company's overall position in the marketplace. For each pair of descriptions, please circle a number that best indicates your assessment of your business's position in its major market.

$\begin{array}{llllllllll}\text { Our prices are usually lower } & 1 & 2 & 3 & 4 & 5 & 6 & 7 & \text { Our prices are usually higher }\end{array}$ than the industry average

Our quality tends to be lower than the industry average

Our service tends to be worse than the industry average

We have lower costs than the industry average

Our products/services tend to have little or no differentiation
than the industry average
$\begin{array}{llllllll}1 & 2 & 3 & 4 & 5 & 6 & 7 & \text { Our quality tends to be higher }\end{array}$ than the industry average

$\begin{array}{llllllll}1 & 2 & 3 & 4 & 5 & 6 & 7 & \text { Our service tends to be better }\end{array}$ than the industry average

$\begin{array}{llllllll}1 & 2 & 3 & 4 & 5 & 6 & 7 & \text { We have higher costs }\end{array}$ than the industry average

$\begin{array}{llllllll}1 & 2 & 3 & 4 & 5 & 6 & 7 & \text { Our products/services tend to be }\end{array}$ highly differentiated

The following descriptions characterize four equally effective strategies that organizations can use to position themselves relative to their competition. Please read through each of the descriptions and check the box next to the one description that most closely resembles your business.

This organization typically operates within a broad product market domain that undergoes periodic redefinition. It values being "first in" with new services and products even if not all these efforts prove to be highly profitable. This organization responds rapidly to early signals concerning areas of opportunity, and these responses often lead to a new round of competitive actions. However, this organization may not maintain market strength in all areas it enters.

This organization typically attempts to locate and maintain a secure niche in a relatively stable product or service area. It tends to offer a more limited range of products or services than competitors, and tries to protect its domain by offering higher quality, superior service, lower prices, and so forth. This organization is not at the forefront of developments in the industry. It tends to ignore changes that have no direct influence on current areas of operation, and concentrates instead on doing the best job possible in a limited area.

- This organization attempts to maintain a stable, limited line of products or services, while at the same time moving quickly to follow a carefully selected set of the more promising new developments in the industry. It is seldom "first in" with new products and services. However, by carefully monitoring the actions of major competitors in areas compatible with its stable productmarket base, this organization can frequently be "second in" with a more cost-efficient product or service.

- This organization does not appear to have a consistent product-market orientation. It is not as aggressive in maintaining established products and markets as some of its competitors, nor is it willing to take as many risks as competitors. Rather, the organization responds in those areas where it is forced to by environmental pressures.

Now please think about the market environment for your firm and indicate how much you agree or disagree with the following statements:
Strongly Disagree
Strongly

Agree 
The technology in our industry changes quite rapidly

$\begin{array}{lllllll}1 & 2 & 3 & 4 & 5 & 6 & 7\end{array}$

Technological changes have provided big opportunities in our industry

A large number of new product ideas have been made possible through

$\begin{array}{lllllll}1 & 2 & 3 & 4 & 5 & 6 & 7\end{array}$

technological breakthroughs in our industry

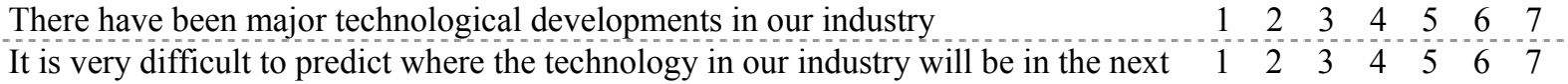

12345667

2 or 3 years

Competition in this industry is cutthroat

There are many promotion wars in this industry

One hears of a new competitive move almost every day

Price competition is a hallmark of this industry

Anything that one competitor can offer, others can readily match

$\begin{array}{llllllll}1 & 2 & 3 & 4 & 5 & 6 & 7\end{array}$

$\begin{array}{lllllll}1 & 2 & 3 & 4 & 5 & 6 & 7\end{array}$

$\begin{array}{lllllll}1 & 2 & 3 & 4 & 5 & 6 & 7\end{array}$

Now, for each pair of statements below, please circle a number that best describe the market for your new products over the past 12 months:

\begin{tabular}{|c|c|c|c|c|c|c|c|c|}
\hline $\begin{array}{l}\text { Predictable } \\
\text { Stable market shres }\end{array}$ & 1 & 2 & 3 & 4 & $\begin{array}{l}5 \\
5\end{array}$ & 6 & 7 & $\begin{array}{l}\text { Unpredictable } \\
\text { Volatile market shares }\end{array}$ \\
\hline Easy to monitor trends & 1 & 2 & 3 & 4 & 5 & 6 & 7 & Difficult to monitor trends \\
\hline Stable industry volume & 1 & 2 & 3 & 4 & 5 & 6 & 7 & Unstable industry volume \\
\hline Certain the selling effort will pay off & 1 & 2 & 3 & 4 & 5 & 6 & 7 & Uncertain the selling effort will pay off \\
\hline $\begin{array}{r}\text { Sales forecasts are likely to be } \\
\text { accurate }\end{array}$ & 1 & 2 & 3 & 4 & 5 & 6 & 7 & Sales forecasts are likely to be inaccurate \\
\hline $\begin{array}{r}\text { Sufficient information for marketing } \\
\text { decisions }\end{array}$ & 1 & 2 & 3 & 4 & 5 & 6 & 7 & $\begin{array}{l}\text { Insufficient information for marketing } \\
\text { decisions }\end{array}$ \\
\hline $\begin{array}{r}\text { Confident of results of marketing } \\
\text { actions }\end{array}$ & 1 & 2 & 3 & 4 & 5 & 6 & 7 & Unsure of results of marketing actions \\
\hline
\end{tabular}

Please indicate how much you agree or disagree with the following statements: Strongly Strongly

Disagree Agree

Our performance over past years has been better than that of everyone else in our $\quad \begin{array}{llllllll}1 & 2 & 3 & 4 & 5 & 6 & 7\end{array}$

industry

We have had few serious threats to our position as industry leaders so far

$\begin{array}{lllllll}1 & 2 & 3 & 4 & 5 & 6 & 7\end{array}$

We have a control in our industry

$\begin{array}{llllllll}1 & 2 & 3 & 4 & 5 & 6 & 7\end{array}$

Other firms try to follow us in the technology

$\begin{array}{lllllll}1 & 2 & 3 & 4 & 5 & 6 & 7\end{array}$

\section{General Questions}

1. Number of full time employees in your firm

2. Please indicate how many new products your firm has introduced during the past three years using the descriptions below:

Number of "line extensions" (products not very new to your organization but new to your

market)

market)

Number of "me-too" products (products new to your organization but not new to your

$\overline{\text { your market) }}$

Number of "new-to-the-world" products (products new to your organization and new to

3. Last year's sales for your firm $\$$

million

Percentage of sales provided by new products less than 3 years old

Percentage of profits provided by new products less than 3 years old

Percentage of market share from new products less than 3 years old

Percentage of sales growth from new products less than 3 years old 


\title{
Please describe your company's profitability last year:
}

\author{
1. Unprofitable 2. Breaking even 3. Moderately profitable 4. Very profitable
}

4. Please rate your knowledge of new product development activities in your firm over the past year: $\begin{array}{lllllllllllll}\text { Little knowledge } & 0 & 1 & 2 & 3 & 4 & 5 & 6 & 7 & 8 & 9 & 10 & \text { Very High knowledge }\end{array}$

How long have you worked in this firm?

What is your job title in this firm

How long have you held this position?

5. Your firm's main industry is

When was your firm founded?

6. Is your firm an independent venture $\square$ or a subsidiary of a corporation $\square$ ?

Please indicate the type of ownership of your firm

Thank you again for your valuable inputs to this important research! 


\section{REFERENCES}

Achrol, Ravi S. (1991), "Evolution of the Marketing Organization: New Forms for Turbulent Environments," Journal of Marketing, 55 (October), 77-93.

and Louis W. Stern (1988), "Environmental Determinants of Decision-Making Uncertainty in Marketing Channels," Journal of Marketing Research, 25 (February), 36-50.

Adams, Marjorie E., George S. Day, and Deborah Dougherty (1998), "Enhancing New Product Development Performance: An Organizational Learning Perspective," Journal of Product Innovation Management, 15, 403-22.

Adner, Ron (2002), "When Are Technologies Disruptive? A Demand-Based View of the Emergence of Competition," Strategic Management Journal, 23, 667-88.

Afuah, Allan (2001), "Dynamics Boundaries of the Firm: Are Firms Better Off Being Vertically Integrated in the Face of Technological Change?" Academy of Management Journal, 44 (6), 1211-28.

Agarwal, S., M.K. Erramilli, and C.S. Dev (2003), "Market Orientation and Performance in Service Firms: Role of Innovation,” Journal of Services Marketing, 17 (1), 68-82.

Ahuja, G. and C.M. Lampert (2001), "Entrepreneurship in the Large Corporation: A Longitudinal Study of How Established Firms Create Breakthrough Inventions," Strategic Management Journal, 22, 521-43.

Akgun, Ali E., Gary S. Lynn, and Richard Reilly (2002), "Multi-Dimensionality of Learning in New Product Development Teams," European Journal of Innovation Management, $5(2), 57-72$.

Ancona, Deborah G. and David F. Caldwell (1992), "Bridging the Boundary: External Activity and Performance in Organizational Teams," Administrative Science Quarterly, 37 (4), 634-65.

Anderson, P. and M.L. Tushman (2001), "Organizational Environments and Industry Exit: The Effects of Uncertainty, Munificence and Complexity," Industrial and Corporate Change, 10, 675-711. 
Anderson, J. C. and D. W. Gerbing (1988), "Structural Equation Modeling in Practice: A Review and Recommended Two-Step Approach," Psychological Bulletin, 103 (3), 411-23.

Andrews, Jonlee and Daniel C. Smith (1996), "In Search of the Marketing Imagination: Factors Affecting the Creativity of Marketing Programs for Mature Products," Journal of Marketing Research, 33 (May), 174-87.

Appiah-Adu, Kwaku (1997), "Market Orientation and Performance: Do the Findings Established in Large Firms Hold in the Small Business Sector?” Journal of Euromarketing, 6 (3), 1-26.

and A. Ranchhod (1998), "Market Orientation in Biotechnology Industry: An Exploratory Empirical Analysis," Technology Analysis and Strategic Management, $10(2), 197-210$.

Argyris, Chris (1982), "The Executive Mind and Double-Loop Learning," Organizational Dynamics, 11 (Autumn), 5-22. (1999), On Organizational Learning (2d ed.). Malden, MA: Blackwell Publishers. and D.A. Schon (1978), Organizational Learning II: Theory, Method, and Practice. Reading, MA: Addison-Wesley.

Armstrong, J. Scott and Fred Collopy (1996), "Competitor Orientation: Effects of Objectives and Information on Managerial Decisions and Profitability," Journal of Marketing Research, 33 (May), 1988-99. and Terry S. Overton (1977), "Estimating Nonresponse Bias in Mail Surveys," Journal of Marketing, 14 (August), 396-402.

Arnould, Eric J. and Melanie Wallendorf (1994), "Market-Oriented Ethnography: Interpretation Building And Marketing Strategy Formulation," Journal of Marketing Research, 31 (November), 484-504.

Arthur, Jeffrey B. and Lynda Aiman-Smith (2001), "Gainsharing and Organizational Learning: An Analysis of Employee Suggestions over Time," Academy of Management Journal, 44 (4), 737-54.

Arthur, W.B. (1984), “Competing Technologies and Economic Prediction,” IIasa Options, 2, $10-13$. 
Atuahene-Gima, K. (1995), “An Exploratory Analysis of the Impact of Market Orientation on New Product Performance," Journal of Product Innovation Management, 12, 27593.

(1996), "Market Orientation and Innovation," Journal of Business Research, 35, 93 103.

and Haiyang Li (2004), "Strategic Decision Comprehensiveness and New Product Outcomes in New Technology Ventures," Academy of Management Journal, 47 (4), 583-97.

Autio, E., H. J. Sapienza, and J.G. Almeida (2000), "Effects of Age at Entry, Knowledge Intensity, and Imitability on International Growth," Academy of Management Journal, 43 (5), 909-24.

Baker, Thomas L., Penny M. Simpson, and Judy A. Siguaw (1999), "The Impact of Suppliers' Perceptions of Reseller Market Orientation on Key Relationship Constructs," Journal of Academy of Marketing Science, 27 (1), 50-57. and James M. Sinkula (1999a), "Learning Orientation, Market Orientation, and Innovation: Integrating and Extending Models of Organizational Performance," Journal of Market-Focused Management, 4, 295-308. and - (1999b), "The Synergistic Effect of Market Orientation and Learning Orientation on Organizational Performance," Journal of Academy of Marketing Science, 27 (4), 411-27.

Baker, W.E. and J.M. Sinkula (2002), "Market Orientation, Learning Orientation and Product Innovation: Delving into the Organization's Black Box," Journal of Market-Focused Management, 5, 5-23.

Barkerma, H.G., O. Shenkar, F. Vermeulen, and J.H.J. Bell (1997), "Working Abroad, Working with Others: How Firms Learn to Operate International Joint Ventures," Academy of Management Journal, 40 (2), 426-42.

Barnett, Carole and Michael Pratt (2000), "From Threat-Rigidity to Flexibility: Toward a Learning Model of Autogenic Crisis in Organizations," Journal of Organizational Change Management, 13 (1), 74-88. 
Baron, R.A. and G.D Markman (2000), "Beyond Social Capital: How Social Skills Can Enhance Entrepreneurs' Success," Academy of Management Executive, 14 (1), 10616.

Barringer, Bruce R. and Allen C. Bluedorn (1999), “The Relationship Between Corporate Entrepreneurship and Strategic Management," Strategic Management Journal, 20, $421-44$.

Beckman, Christine M. and Pamela R. Haunschild (2002), "Network Learning: The Effects of Partners' Heterogeneity of Experience on Corporate Acquisitions," Administrative Science Quarterly, 47, 92-124.

$\longrightarrow,-$, and Damon J. Phillips (2004), "Friends or Strangers? Firm-Specific Uncertainty, Market Uncertainty, and Network Partner Selection," Organization Science, 15 (3), 259-75.

Bell, Simon J., Gregory J. Whitewell, and Bryan A. Lukas (2002), "Schools of Thought in Organizational Learning," Journal of the Academy of Market Science, 30 (1), 70-86.

Bennett, Roger C. and Robert G. Cooper (1979), "Beyond the Marketing Concept," Business Horizons, 22 (3), 76-83.

— and (1981), "The Misuse of Marketing: An American Tragedy," Business Horizons, 24 (6), 51-61.

Berthon, Pierre, James Mac Hulbert, and Leyland Pitt (2004), "Innovation or Customer Orientation? An Empirical Investigation," European Journal of Marketing, 38 (9-10), 1065-90.

Bhide, A.V. (2000), The Origin and Evolution of New Business. New York: Oxford Press.

Bhuian, Shahid N. (1997), "Exploring Market Orientation in Banks: An Empirical Examination in Saudi Arabia," Journal of Services Marketing, 11 (5), 317-28.

Bigne, E., I. Kuster, and F. Toran (2003), "Market Orientation and Industrial Salesforce: Diverse Measure Instruments," Journal of Business \& Industrial Marketing, 18 (1), 59-81.

Bonoma, Thomas V. (1985), "Case Research in Marketing: Opportunities, Problems, and a Process," Journal of Marketing Research, 22 (May), 199-208. 
Booz Allen Hamilton (1982), New Products Management for the 1980's. New York: Booz Allen Hamilton.

Brockman, Beverly K. and Robert M. Morgan (2003), "The Role of Existing Knowledge in New Product Innovativeness and Performance," Decision Sciences, 34 (2), 385-419.

Brown, A.D. and K. Starkey (2000), "Organizational Identity and Learning: A

Psychodynamic Perspective," Academy of Management Review, 25 (1), 102-20.

Brown, Shona L. and Kathleen M. Eisenhardt (1995), "Product Development: Past Research, Present Findings, and Future Directions," Academy of Management Review, 20 (2), $343-78$.

Burgelman, R.A. (1983), "Corporate Entrepreneurship and Strategic Management: Insights from a Process Study," Management Science, 29, 1349-64.

Burt, R.S. (1992), Structural Holes: The Social Structural of Competition. Cambridge, MA: Harvard University Press.

Cadogan, John W., Adamantios Diamantopoulos, and Judy A. Siguaw (2002), "Export Market-Oriented Activities: Their Antecedents and Performance Consequences," Journal of International Business Studies, 33 (3), 615-26.

Calantone, Roger J., Jeffrey B. Schmidt, and X. Michael Song (1996), "Controllable Factors of New Product Success: A Cross-National Comparison.," Marketing Science, 38 (2), $157-69$.

Camp, Robert C. (1995), Business Process Benchmarking: Finding and Implementing Best Practices. Milwaukee: ASQC Quality Press.

Cardinal, L.B. (2001), "Technological Innovation in the Pharmaceutical Industry: The Use of Organizational Control in Managing Research and Development," Organization Science, 12 (1), 19-36.

Carmel, Erran (1995), “Cycle Time in Packaged Software Firms," Journal of Product Innovation Management, 12 (2), 110-33.

Caruana, Albert, B. Ramaseshan, and Michael T. Ewing (1999), "Market Orientation and Performance in the Public Sector: The Role of Organizational Commitment," Journal of Global Marketing, 12 (3), 59-79. 
Celly, Kirti Sawhney and Gary L. Frazier (1996), "Outcome-Based and Behavior-Based Coordination Efforts in Channel Relationships," Journal of Marketing Research, 33 (May), 200-10.

Celuch, K.G., C.J. Kasouf, and V. Peruvemba (2002), "The Effects of Perceived Market and Learning Orientation on Assessed Organizational Capabilities," Industrial Marketing Management, 31, 545-54.

Cervera, A., A. Molla, and M. Sanchez (2001), "Antecedents and Consequences of Market Orientation in Public Organisations," European Journal of Marketing, 35 (11-12), $1259-86$.

Chandy, Rajesh K., J.C. Prabhu, and Kersi Antia (2003), "What Will the Future Bring? Dominance, Technology Expectations, and Radical Innovation," Journal of Marketing, 67 (July), 1-18.

and Gerard J. Tellis (1998), "Organizing for Radical Product Innovation: The Overlooked Role of Willingness to Cannibalize," Journal of Marketing Research, 35 (November), 474-87.

Chang, Tung-Zong and Su-Jane Chen (1998), "Market Orientation, Service Quality and Business Profitability: A Conceptual Model and Empirical Evidence," Journal of Services Marketing, 12 (4), 246-64.

Christensen, Clayton M. and Joseph L. Bower (1996), "Customer Power, Strategic Investment, and the Failure of Leading Firms," Strategic Management Journal, 17 (March), 197-218.

and Michael E. Raynor (2003a), “Creating A Killer Product," Forbes, 172 (8), 82. and - (2003b), "What Customers Really Want Is for You to Do Their Jobs; To Make Innovative Products That Drive Growth, Companies Must Forget About Demographics, Product Attributes and Market Size Data, and Focus on the Specific Jobs Customers Need to Get Done," CIO, 17 (4), 1.

— , F. Suarez, and J. Utterback (1998), "Strategies for Survival in Fast Changing Industries," Management Science, 44 (12), 207-20.

Churchill, Gilbert A. (1995), Marketing Research: Methodological Foundations. London: Dryden Press. 
(1979), "A Paradigm for Developing Better Measures of Marketing Constructs," Journal of Marketing Research, 16 (February), 64-73.

Clark, Mark A., Susan D. Amundson, and Robert L. Cardy (2002), "Cross-Functional Team Decision-Making and Learning Outcomes: A Qualitative Illustration," Journal of Business and Management, 8 (3), 217-36.

Cohen, W.M. and D.A. Levinthal (1990), "Absorptive Capacity: A New Perspective on Learning and Innovation," Administrative Science Quarterly, 35, 128-52.

Cook, Thomas D. and Donald T. Campbell (1979), Quasi-Experimentation: Design and Analysis Issues for Field Settings. Boston: Houghton Mifflin.

Cooper, R.G. (1994), "New Products: The Factors That Drive Success," International Marketing Review, 11 (1), 60-76.

Covin, J.G. and D.P. Slevin (1989), "Strategic Management of Small Firms in Hostile and Benign Environments," Strategic Management Journal, 10 (1), 75-87.

and - (1991), "A Conceptual Model of Entrepreneurship as Firm Behavior," Entrepreneurship Theory and Practice, 15, 7-25.

Cravens, David W. (1998), "Implementation Strategies in the Market-Driven Strategy Era," Journal of Academy of Marketing Science, 26 (3), 237-41.

, Gordon Greenley, Nigel F. Piercy, and Stanley F. Slater (1998), "Mapping the Path to Market Leadership: Effectively Combining Various Dimensions of Strategy into an Integrated Process of Strategic Analysis and Action Maps the Path to Market Leadership," Marketing Management, 7 (3), 29-39.

Crawford, C. Merle (1992), "The Hidden Costs of Accelerated Product Development," Journal of Product Innovation Management, 9 (September), 188-99.

and C. Anthony Di Benedetto (2000), New Product Management. Boston: Irwin/McGraw-Hill.

Crossan, M.M., H.W. Lane, and R.E. White (1999), “An Organizational Learning Framework: From Intuition to Institution," Academy of Management Review, 24 (3), $522-37$. 
Cyert, R.M. and J.G. March (1963), A Behavioral Theory of the Firm. Englewood Cliffs, NJ: Prentice-Hall.

and J.R. Williams (1993), "Organizations, Decision Making and Strategy: Overview and Comment," Strategic Management Journal, 14, 5-10.

Damanpour, Fariborz (1991), "Organizational Innovation: A Meta-Analysis of Effects of Determinants and Moderators," Academy of Management Journal, 34 (3), 555-90.

and William M. Evan (1984), "Organizational Innovation and Performance: The Problem of 'Organizational Lag'," Administrative Science Quarterly, 29 (3), 392409.

Danneels, Erwin (2003), "Tight-Loose Coupling with Customers: The Enactment of Customer Orientation," Strategic Management Journal, 24, 559-76.

D'Aunno, Thomas, Melissa Succi, and Jeffrey A. Alexander (2000), "The Role of Institutional and Market Forces in Divergent Organizational Change," Administrative Science Quarterly, 45 (4), 679-703.

Davis, D. and R.M. Cosenza (1993), Business Research for Decision Making. Belmont, California: Wadsworth Publishing Company.

Day, George S. (1994), “The Capabilities of Market-Driven Organization," Journal of Marketing, 58 (October), 37-52.

(1990), Market-Driven Strategy: Process for Creating Value. New York: Free Press. and Robin Wensley (1988), “Assessing Advantage: A Framework for Diagnosing Competitive Superiority,” Journal of Marketing, 52 (April), 1-20.

Delmas, Magali A. (2002), "Innovating Against European Rigidities: Institutional Environment and Dynamic Capabilities," Journal of High Technology Management Research, 13, 19-43.

Deng, S. and J. Dart (1994), "Measuring Market Orientation: A Multi-Factor, Multi-Item Approach," Journal of Marketing Management, 10 (8), 725-42.

Deshpandé, R. and J.U. Farley (1999), "Executive Insights: Corporate Culture and Market Orientation: Comparing Indian and Japanese Firms," Journal of International Marketing, 7 (4), 111-27. 
and - (1998), “The Market Orientation Construct: Correlations, Culture, and Comprehensiveness," Journal of Market-Focused Management, 2, 237-39.

— Innovativeness in Japanese Firms: A Quadrad Analysis," Journal of Marketing, 57 (January), 23-27.

Dess, Gregory G., R. Duane Ireland, Shaker A. Zahra, Steven W. Floyd, Jay J. Janney, and Peter J. Lane (2003), "Emerging Issues in Corporate Entrepreneurship," Journal of Management, 29 (3), 351-78.

Dewar, Robert D. and Jane E. Dutton (1986), "The Adoption of Radical and Incremental Innovations: An Empirical Analysis,” Management Science, 32 (11), 1422-33.

Dickson, Peter Reid (1992), “Toward a General Theory of Competitive Rationality,” Journal of Marketing, 56 (January), 69-83.

DiMaggio, Paul J. and Walter W. Powell (1991), "Introduction," in The New Institutionalism in Organizational Analysis, Walter W. Powell and Paul J. DiMaggio, Eds. Chicago, IL: University of Chicago Press.

Dobrev, Stanislav, Tai-Young Kim, and Glenn R. Carroll (2003), "Shifting Gears, Shifting Niches: Organizational Inertia and Change in the Evolution of the U.S. Automobile Industry, 1885-1981," Organization Science, 14 (3), 264-82.

Dougherty, Deborah (1992), "Interpretive Barriers to Successful Product Innovation in Large Firms," Organization Science, 3 (2), 179-202.

Duguet, Emmanuel and Megan MacGarvie (2005), "How Well Do Patent Citations Measure Flows of Technology? Evidence from French Innovation Surveys," Economics of Innovation and New Technology, 14 (5), 375-93.

Dutta, Shantanu, Om Narasimhan, and Surendra Rajiv (1999), "Success in High-Technology Markets: Is Marketing Capability Critical?” Marketing Science, 18 (4), 547-68.

Dyer, Jeffrey H. and Harbir Singh (1998), "The Relational View: Cooperative Strategy and Sources of Interorganizational Competitive Advantage," Academy of Management Review, 23 (4), 660-79. 
Egeren, Marsha Van and Stephen O'Conner (1998), "Drivers of Market Orientation and Performance in Service Firms," Journal of Services Marketing, 12 (1), 39-58.

Eisenhardt, Kathleen M. (1989), "Building Theories from Case Study Research," Academy of Management Review, 14 (4), 532-50.

and Jeffrey A. Martin (2000), “Dynamic Capabilities: What Are They?" Strategic Management Journal, 21 (10-11), 1105-21.

Emory, C.W. and D.R. Cooper (1991), Business Research Methods. Homewood, IL: Irwin.

Ettlie, John E., William P. Bridges, and Robert D. O’Keefe (1984), “Organization Strategy and Structural Differences for Radical Versus Incremental Innovation," Management Science, 30 (6), 682-95.

Farrell, M.A. (2000), "Developing a Market-Oriented Learning Organisation," Australian Journal of Management, 25 (2), 201-22. and E. Oczkowski (2002), “Are Market Orientation and Learning Orientation Necessary for Superior Organizational Performance?” Journal of Market-Focused Management, 5, 197-217.

Farrelly, Francis and Pascale Quester (2003), "The Effects of Market Orientation on Trust and Commitment: The Case of the Sponsorship Business-to-Business Relationship," European Journal of Marketing, 37 (3-4), 530-53.

Fiol, C.M. (1994), “Consensus, Diversity, and Learning in Organizations," Organization Science, 5 (3), 403-20. and M.A. Lyles (1985), “Organizational Learning," Academy of Management Review, 10, 803-13.

Fisher, S.R. and M.A. White (2000), "Downsizing in A Learning Organization: Are There Hidden Costs?” Academy of Management Review, 25 (1), 244-51.

Floyd, S.M. and P.J. Lane (2000), "Strategizing Throughout the Organization: Management Role Conflict in Strategic Renewal," Academy of Management Review, 25, 154-77.

Foil, C. Marlene and Marjorie A. Lyles (1985), "Organizational Learning," Academy of Management Review, 10 (4), 803-13. 
Fornell, Claes, Michael D. Johnson, Eugene W. Anderson, Jaesung Cha, and Barbara Everitt Bryant (1996), "The American Customer Satisfaction Index: Nature, Purpose, and Findings," Journal of Marketing, 60 (October), 7-18. and David F. Larcker (1981), "Evaluating Structural Equation Models with Unobservable Variables and Measurement Error," Journal of Marketing Research, 18 (1), 39-50.

and Birger Wernerfelt (1987), "Defensive Marketing Strategy by Customer Complaint Management: A Theoretical Analysis," Journal of Marketing Research, 24 (November), 337-46.

Fredrickson, James W. and Anthony L. Iaquinto (1989), "Inertia and Creeping Rationality in Strategic Decision Process," Academy of Management Journal, 32 (3), 516-42.

Frese, Michael, Anouk Brantjes, and Rogier Hoorn (2002), "Psychological Success Factors of Small Scale Business in Namibia: The Roles of Strategy Process, Entrepreneurial Orientation and the Environment," Journal of Development Entrepreneurship, 7 (3), $259-82$.

Gainer, Brenda and Paulette Padanyi (2002), "Applying the Marketing Concept to Cultural Organisations: Am Empirical Study of the Relationship Between Market Orientation and Performance," International Journal of Nonprofit and Voluntary Sector Marketing, 7 (2), 182-93.

Galbraith, J.R. (1977), Organization Design. Reading, MA: Addison-Wesley.

Gatignon, Hubert, Michael Tushman, Wendy Smith, and Philip Anderson (2002), “A Structural Approach to Assessing Innovation: Construct Development of Innovation Locus, Type, and Characteristics," Management Science, 48 (9), 1103-22. and Jean-Marc Xuereb (1997), "Strategic Orientation of the Firm and New Product Performance," Journal of Marketing Research, 34 (February), 77-90.

Geletkanycz, M.A. (1997), “The Salience of Culture's Consequences: The Effects of Cultural Values on Top Executive Commitment to the Status Quo," Strategic Management Journal, 18 (8), 615-34.

Gerbing, David W. and James C. Anderson (1988), "An Updated Paradigm for Scale Development Incorporating Unidimensionality and Its Assessment," Journal of Marketing Research, 25 (May), 186-92. 
Gersick, C.J.G. (1991), "Revolutionary Change Theories: A Multilevel Exploration of the Punctuated Equilibrium Paradigm," Academy of Management Review, 16 (1), 10-36.

Glazer, Rashi (1991), "Marketing in an Information-Intensive Environment: Strategic Implications of Knowledge as an Asset," Journal of Marketing, 55 (October), 1-18.

Goebel, Daniel J., Greg W. Marshall, and William B. Locander (1998), "Activity-Based Costing: Accounting for a Market Orientation," Industrial Marketing Management, 27 (6), 497-510.

Golder, Peter N. and Gerard J. Tellis (1993), "Pioneer Advantage: Marketing Logic or Marketing Legend?” Journal of Marketing Research, 30 (May), 158-70.

Gray, B., S. Matear, C. Boshoff, and P. Matheson (1998), "Developing a Better Measure of Market Orientation," European Journal of Marketing, 32 (9-10), 884-903.

Greenley, G.E. (1995), "Market Orientation and Company Performance: Empirical Evidence from UK Companies," British Journal of Management, 6, 1-13.

Gresov, Christopher, Heather A. Haveman, and Terence A. Oliva (1993), "Organizational Design, Inertia and the Dynamics of Competitive Response," Organizational Science, 4 (2), 181-208.

Greve, Henrich R (2003), “A Behavioral Theory of R\&D Expenditures and Innovations: Evidence from Shipbuilding," Academy of Management Journal, 46 (6), 685-702.

Grewal, Rajdeep, James M. Comer, and Raj Mehta (2001), “An Investigation into the Antecedents of Organizational Participation in Business-to-Business Electronic Markets," Journal of Marketing, 65 (July), 17-33. and P. Tansuhaj (2001), "Building Organizational Capabilities for Managing Economic Crisis: The Role of Market Orientation and Strategic Flexibility," Journal of Marketing, 65 (April), 67-80.

Griffin, Abbie and John R. Hauser (1993), "The Voice of the Customer," Marketing Science, $12(1), 1-28$.

Griffin, Mark A., Paul E. Tesluck, and Rick R. Jacobs (1995), "Bargaining Cycles and WorkRelated Attitudes: Evidence for Threat-Rigidity Effects," Academy of Management Journal, 38 (6), 1709-25. 
Grove, Andrew S. (1990), "The Future of the Computer Industry," California Management Review, 33 (1), 148-60.

Gulati, Ranjay, Nitin Nohria, and Akbar Zaheer (2000), "Strategic Networks," Strategic Management Journal, 21, 203-15.

Gupta, A.K., S.P. Raj, and D. Wilemon (1986), "A Model for Studying R\&D-Marketing Interface in the Product Innovation Process," Journal of Marketing, 50 (April), 7-17.

Hambrick, D.C. (1981), "Environment, Strategy, and Power Within Top Management Teams," Administrative Science Quarterly, 26, 253-76.

Hambrick, D.C., M.A. Geletkanycz, and J.W. Fredrickson (1993), “Top Executive Commitment to the Status Quo: Some Tests of Its Determinants," Strategic Management Journal, 14 (6), 401-18.

Hamel, Gary (1991), "Competition for Competence and Inter-Partner Learning Within International Strategic Alliances," Strategic Management Journal, 12, 83-103. and C.K. Prahalad (1994), "Seeing the Future First," Fortune, September (5), 64-70.

Hammond, John S., Ralph L. Keeney, and Howard Raiffa (1999), Smart Choices: A Practical Guide to Making Better Decisions. Boston: Harvard Business School Press.

Han, J.K., N. Kim, and R.K. Sirvastava (1998), "Market Orientation and Organizational Performance: Is Innovation a Missing Link?" Journal of Marketing, 62 (October), $30-45$.

Hannan, Michael T. and John Freeman (1977), "The Population Ecology of Organizations," American Journal of Sociology, 82, 929-64. and - (1984), "Structural Inertia and Organizational Change," American Sociological Review, 49 (2), 149-64. and - (1989), Organizational Ecology. Cambridge, MA: Harvard University Press.

Harrington, Robert, David Lemak, and K.W. Kendall (2002), "The Threat-Rigidity Thesis in Newly Formed Teams: An Empirical Test," Journal of Business and Management, 8 (2), 127-45. 
Harris, Lloyd C. (1999), "Barriers to Developing Market Orientation," Journal of Applied Management Studies, 8 (1), 85-101.

(2002), "Measuring Market Orientation: Exploring a Market Oriented Approach," Journal of Market-Focused Management, 5, 239-70.

and E. Ogbonna (2001), "Leadership Style and Market Orientation: An Empirical Study," European Journal of Marketing, 35 (5-6), 744-64.

- and - (1999), "Developing a Market Oriented Culture: A Critical Evaluation," The Journal of Management Studies, 36 (2), 177-96.

— and - (2000), "The Responses of Front-Line Employees to Market-Oriented Culture Change," European Journal of Marketing, 34 (3-4), 318-40.

Harwood, E. (1982), “The Sociology of Entrepreneurship," in Encyclopedia of Entrepreneurship, C. Kent and D. Sexton and Versper K., eds. Englewood Cliffs, NJ: Prentice Hall.

Hedberg, B.L., P.C. Nystrom, and W.H. Starbuck (1976), "Camping on Seesaws: Prescription for a Self-Designing Organization," Administrative Science Quarterly, $21,41-65$.

Helfat, Constance E. (1997), "Know-how and Asset Complementarity and Dynamic Capability Accumulation: The Case of R\&D," Strategic Management Journal, 18 (5), $339-60$.

Henard, David H. and David M. Szymanski (2001), "Why Some New Products Are More Successful Than Others," Journal of Marketing Research, 38 (August), 362-75.

Henderson, Rebecca M. and Kim B. Clark (1990), “Architectural Innovation: The Reconfiguration of Existing," Administrative Science Quarterly, 35 (1), 9-30.

Hirschman, Albert O. (1970), Exit, Voice, and Loyalty—Responses to Decline in Firms, Organizations, and States. Cambridge, MA: Harvard University Press.

Hirschman, Elizabeth C. (1986), "Humanistic Inquiry in Marketing Research: Philosophy, Method, and Criteria," Journal of Marketing Research, 23 (August), 237-49.

Hitt, M.A., R.D. Ireland, and R.E. Hoskisson (1999), Strategic Management: Competitiveness and Globalization. Cincinnati: South-Western College Publishing. 
Hlavacek, James D. and Victor A. Thompson (1973), "Bureaucracy and New Product Innovation," Academy of Management Journal, 1973 (16), 361-72.

Homburg, C. and C. Pflesser (2000), "A Multiple-Layer Model of Market-Oriented Organizational Culture: Measurement Issues and Performance Outcomes," Journal of Marketing Research, 37 (November), 449-62.

Hooley, Graham, John Fahy, Gordon Greenly, Jozsef Beracs, Fonfara Krzysztof, and Boris Snoj (2003), "Market Orientation in the Service of the Transition Economies of Central Europe," European Journal of Marketing, 37 (1-2), 86-106.

Horng, Shun-Ching and Arthur Cheng-Hsui Chen (1998), "Market Orientation of Small and Medium-Sized Firms in Taiwan," Journal of Small Business Management, 36 (3), 79-85.

Houston, Franklin S. (1986), "The Marketing Concept: What It Is and What It Is Not," Journal of Marketing, 50 (April), 81-87.

Houston, Mark B., Beth A. Walker, Michael D. Hutt, and Peter H. Reingen (2001), "CrossUnit Competition for a Market Charter: The Enduring Influence of Structure," Journal of Marketing, 65 (April), 19-34.

Huber, G.P. (1991), "Organizational Learning: The Contributing Processes and the Literatures," Organization Science, 2 (1), 88-115.

Hult, G.T. and D.J. Ketchen Jr. (2001), "Does Market Orientation Matter? A Test of the Relationship Between Positional Advantage and Performance," Strategic Management Journal, 22 (9), 899-906.

Hunt, Shelby and Robert M. Morgan (1995), “The Comparative Advantage Theory of Competition," Journal of Marketing, 59 (April), 1-15.

Hurley, R.F. and G.T.M. Hult (1998), "Innovation, Market Orientation, and Organizational Learning: An Integration and Empirical Examination," Journal of Marketing, 42 (July), 42-54.

Im, Subin, Cheryl Nakata, Heungsoo Park, and Young-Won Ha (2003), "Determinants of Korean and Japanese New Product Performance: An Interrelational and Process View," Journal of International Marketing, 11 (4), 81-112. 
and John Workman (2004), "Market Orientation, Creativity, and New Product Performance in High-Technology Firms," Journal of Marketing, 68 (April), 114-32.

Ireland, R. Duane, Michael A. Hitt, Richard A. Bettis, and Deborah Auld Porras (1987), "Strategy Formulation Processes: Differences in Perceptions of Strength and Weakness Indicators and Environmental Uncertainty by Managerial Level," Strategic Management Journal, 8, 469-85.

Janis, I.L. (1982), Groupthink: Psychological Studies on Policy Decisions and Fiascoes. Boston: Houghton Mifflin.

Jaworski, Bernard J. and Ajay K. Kohli (1993), "Market Orientation: Antecedents and Consequences," Journal of Marketing, 57 (July), 53-70.

- and - (1996), "Market Orientation: Review, Refinement and Roadmap," Journal of Market-Focused Management, 1 (2), 119-35.

— - - and Arvind Sahay (2000), "Market-Driven Versus Driving Markets," Journal of the Academy of Market Science, 28 (1), 45-54.

Jehn, Karen and Elizabeth A. Mannix (2001), "The Dynamic Nature of Conflict: A Longitudinal Study of Intragroup Conflict and Group Performance," Academy of Management Journal, 44 (2), 238-51.

John, George, Allen M. Weiss, and Shantanu Dutta (1999), "Marketing in TechnologyIntensive Markets: Toward a Conceptual Framework," Journal of Marketing, 63 (Special Issue), 78-91.

Joshi, Ashwin W. and Sanjay Sharma (2004), "Customer Knowledge Development: Antecedents and Impact on New Product Performance," Journal of Marketing, 68 (October), 47-59.

Kahn, Kenneth B. (2001), "Market Orientation, Interdepartmental Integration, and Product Development Performance," Journal of Product Innovation Management, 18, 31423.

Kanter, R.M. (1989), When Giants Learn to Dance. New York: Touchstone.

Katila, Riitta (2002), "New Product Search over Time: Past Ideas in Their Prime?” Academy of Management Journal, 45 (5), 995-1010. 
Kelly, Dawn and Terry L. Amburgey (1991), "Organizational Inertia and Momentum: A Dynamic Model of Strategic Change," Academy of Management Journal, 34 (3), 591-613.

Keppel, G., W.H. Saufley, and H. Tokunaga (1992), Introduction to Design Analysis: A Student's Handbook. New York: W.H. Freeman.

Kessler, E.H. and A.K. Chakrabarti (1996), "Innovation Speed: A Conceptual Model of Context, Antecedents, and Outcomes," Academy of Management Review, 21 (4), 1143-91.

Kets de Vries, M. (1977), "The Entrepreneurial Personality: A Person at the Crossroads," Journal of Management Studies, 14, 34-57.

Khandwalla, P.N. (1977), The Design of Organizations. New York: Harcourt Brace Jovanovich.

Kim, Namwoon and Kwaku Atuahene-Gima (2004), "The Impact of Market Learning on New Product Performance: The Mediating Role of New Product Positional Advantages," AMA Winter Educators' Conference Proceedings, 15, 104-105.

King, John Leslie and Joel West (2002), "Ma Bell's Orphan: U.S. Cellular Telephony, 19471996," Telecommunications Policy, 26 (3-4), 189-203.

Kirzner, Israel M. (1997), "Entrepreneurial Discovery and the Competitive Market Process: An Austrian Approach," Journal of Economic Literature, 35 (1), 60-85.

Kohli, Ajay K. and Bernard J. Jaworski (1990), "Market Orientation: The Construct, Research Propositions, and Managerial Implications," Journal of Marketing, 54 (April), 1-18.

— , and A. Kumar (1993), "MAKOR: A Measure of Market Orientation," Journal of Marketing Research, 30 (November), 467-77.

Kraatz, M.S. (1998), "Learning by Association? Interorganizational Networks and Adaptation to Environmental Change," Academy of Management Journal, 41 (6), $621-43$.

Kreiser, Patrick, Louis D. Marino, and K. Mark Weaver (2002), "Assessing the Psychometric Properties of the Entrepreneurial Orientation Scale: A Multi-Country Analysis," Entrepreneurship Theory and Practice, 26 (4), 71-94. 
Krepapa, Areti, Pierre Berthon, Dave Webb, and Leyland Pitt (2003), "Mind the Gap: An Analysis of Service Provider Versus Customer Perceptions of Market Orientation and the Impact on Satisfaction," European Journal of Marketing, 37 (1-2), 197-217.

Kuratko, Donald F., Ray V. Nontagno, and Jeffrey S. Hornsby (1990), "Developing an Intrapreneurial Assessment Instrument for an Effective Corporate Entrepreneurial Environment," Strategic Management Journal, 11, 49-58.

Langerak, Fred (2001), "The Relationship Between Consumer and Supplier Perceptions of the Manufacturer's Market Orientation and Its Business Performance," International Journal of Market Research, 4 (1), 43-62.

—_ Erik Jan Hultink, and Henry S.J. Robben (2004), "The Impact of Market Orientation, Product Advantage, and Launch Proficiency on New Product Performance and Organizational Performance," The Journal of Product Innovation Management, 21 (2), 79-94.

Lant, T.K. and S.J. Mezias (1990), "Managing Discontinuous Change: A Simulation Study of Organizational Learning and Entrepreneurship," Strategic Management Journal, 11 (summer), 147-79.

Larson, A. (1992), "Network Dyads in Entrepreneurial Settings: A Study of the Governance of Exchange Relationships," Administrative Science Quarterly, 37, 76-104.

Lau, Chung Ming, David K. Tse, and Nan Zhou (2002), "Institutional Forces and Organizational Culture in China: Effects on Change Schemas, Firm Commitment and Job Satisfaction," Journal of International Business Studies, 33 (3), 533-50.

Lee, Ching Chyi, Jie Yang, and Li Ming Yu (2001), "The Knowledge Value of Customers and Employees in Product Quality," Journal of Management Development, 20 (7-8), 691-705.

Lee, Choonwoo, Kyungmook Lee, and Johannes M. Pennings (2001), "Internal Capabilities, External Networks, and Performance: A Study on Technology-Based Ventures," Strategic Management Journal, 22 (6-7), 615-40.

Lees-Marshment, Jennifer (2001), "The Product, Sales and Market-Oriented Party: How Labour Learnt to Market the Product, not Just the Presentation," European Journal of Marketing, 35 (9-10), 1074-84. 
Leifer, Richard, Christopher M. McDermott, Gina Colarelli O’Connor, Lois S. Peters, Mark P. Rice, and Robert W. Veryzer (2000), Radical Innovation: How Mature Companies Can Outsmart Upstarts. Boston: Harvard Business School Press.

Leonard-Barton, Dorothy (1992), "Core Capabilities and Core Rigidities: A Paradox in Managing New Product Development," Strategic Management Journal, 13 (summer), $111-25$.

Levinthal, D. and J.G. March (1993), "The Myopia of Learning," Strategic Management Journal, 14, 95-112.

Levitt, Barbara and James G. March (1988), “Organizational Learning,” Annual Review of Sociology, 14, 319-40.

Li, Stan Xiao and Timothy J. Rowley (2002), "Inertia and Evaluation Mechanisms in Interorganizational Partner Selection: Syndicate Formation Among U.S. Investment Banks," Academy of Management Journal, 45 (6), 1104-19.

Li, Tiger and Roger J. Calantone (1998), "The Impact of Market Knowledge Competence on New Product Advantage: Conceptualization and Empirical Examination," Journal of Marketing, 62 (October), 13-29.

Lieberman, M. and D.B. Montgomery (1988), "First-Mover Advantages," Strategic Management Journal, 9 (summer), 41-58.

Liebeskind, J.P., A.L. Oliver, L. Zucker, and M. Brewer (1996), "Social Networks, Learning, and Flexibility: Sourcing Scientific Knowledge in New Biotechnology Firms," Organization Science, 7 (4), 428-43.

Lilien, Gary L., Pamela D. Morrison, Kathleen Searls, Mary Sonnack, and Eric von Hippel (2002), "Performance Assessment of the Lead User Idea-Generation Process of New Product Development," Management Science, 48 (8), 1042-59.

Liu, Sandra S., Xueming Luo, and Yi-Zheng Shi (2002), "Integrating Customer Orientation, Corporate Entrepreneurship, and Learning Orientation in Organizations-in-Transition: An Empirical Study," International Journal of Research in Marketing, 19, 367-82.

Lovelace, Kay, Debra L. Shapiro, and Laurie R. Weingart (2001), "Maximizing CrossFunctional New Product Teams' Innovativeness and Constraint Adherence: A Conflict Communications Perspectives," Academy of Management Journal, 44 (4), 779-93. 
Luchins, Abraham and Edith H. Luchins (1970), Wertheimer's Seminars Revisited: Problem Solving and Thinking. Albany: State University of New York.

Lukas, Bryan A. (1999), "Strategic Type, Market Orientation, and the Balance Between Adaptability and Adaptation," Journal of Business Research, 45 (2), 147-56. and O.C. Ferrell (2000), "The Effect of Market Orientation on Product Innovation," Journal of the Academy of Market Science, 28 (2), 239-47.

Lumpkin, G.T. and G.G. Dess (1996), "Clarifying the Entrepreneurial Orientation Construct and Linking It to Performance," Academy of Management Review, 21 (1), 135-72.

Luo, Yadong (2003), "Industrial Dynamics and Managerial Networking in an Emerging Market: The Case of China," Strategic Management Journal, 24 (13), 1315-27.

Lynn, Gary S., Richard B. Skov, and Kate D. Abel (1999), "Practices That Support Team Learning and Their Impact on Speed to Market and New Product Success," The Journal of Product Innovation Management, 16 (5), 439-54.

Lyon, Douglas W., G.T. Lumpkin, and Gregory G. Dess (2000), "Enhancing Entrepreneurial Orientation Research: Operationalizing and Measuring a Key Strategic Decision Making Process," Journal of Management, 26 (5), 1055-85.

Maltz, Elliot and Ajay K. Kohli (2000), "Reducing Marketing's Conflict with Other Functions: The Differential Effects of Integrating Mechanisms," Journal of the Academy of Market Science, 28 (4), 479-92.

March, J.G. (1991), "Exploration and Exploitation in Organizational Learning," Organizational Science, 2 (1), 71-87.

Martin, J.H., B.A. Martin, and B. Grbac (1998), "Employee Involvement and Market Orientation in a Transition Economy: Importance, Problems, and a Solution," Journal of Managerial Issues, 5 (1), 485-502.

Mason, E.J. and W.J. Bramble (1989), Understanding and Conducting Research. New York: McGraw-Hill.

Matear, S., P. Osborne, T. Garrett, and B. Gray (2002), "How Does Market Orientation Contribute to Service Firm Performance? An Examination of Alternative Mechanisms," European Journal of Marketing, 36 (9-10), 1058-75. 
Matsuno, Ken and John T. Mentzer (2000), "The Effects of Strategy Type on the Market Orientation-Performance Relationship," Journal of Marketing, 64 (October), 1-16.

_ _ - and Ayşegül Özsomer (2002), “The Effects of Entrepreneurial Proclivity and Market Orientation on Business Performance," Journal of Marketing, 66 (July), $18-32$.

Mavondo, Felix Tinoziva (1999), "Market Orientation: Scale Invariance and Relationship to Generic Strategies Across Two Countries," Journal of Market-Focused Management, $4(2), 125-42$.

McCarthy, E. Jerome and William D. Perreault (1990), Basic Marketing. Homewood, IL: Irwin.

McGrath, R.G. (2001), “Exploratory Learning, Innovative Capacity, and Managerial Oversight," Academy of Management Journal, 44 (1), 118-31.

I.C. MacMillan, and S. Scheinberg (1992), "Elitists, Risk Takers and Rugged Individualists? An Exploratory Analysis of Differences Between Entrepreneurs and Non-entrepreneurs," Journal of Business Venturing, 7, 115-35.

Mckee, Daryl (1992), "An Organizational Learning Approach to Product Innovation," Journal of Product Innovation Management, 9, 232-45.

Menguc, Bulent (1996), "The Influence of the Market Orientation of the Firm on Sales Force Behavior and Attitudes: Further Empirical Results," International Journal of Research in Marketing, 13 (3), 277-91.

Menon, Ajay and Bryan A. Lukas (2004), “Antecedents and Outcomes of New Product Development Speed,” European Journal of Marketing, 38 (1-2), 209-23.

Methe, David T., Ryoko Toyama, and Junichiro Miyabe (1997), "Product Development Strategy and Organizational Learning: A Tale of Two PC Makers," Journal of Product Innovation Management, 14, 323-36.

Meyer, John W. and Brian Rowan (1977), "Institutionalized Organizations: Formal Organizations As Myth and Ceremony," American Journal of Sociology, 83, 340-63.

Miles, M.P. and D.R. Arnold (1991), "The Relationship Between Marketing Orientation and Entrepreneurial Orientation," Entrepreneurship Theory and Practice, 15 (summer), 49-65. 
Miles, Raymond E. and Charles C. Snow (1992), "Causes of Failure in Network Organizations," California Management Review, 34 (4), 53-72.

Miller, Danny (1983), "The Correlates of Entrepreneurship in Three Types of Firms," Management Science, 29, 770-91.

(1990), The Icarus Paradox: How Exceptional Companies Bring About Their Own Downfall: New Lessons in the Dynamics of Corporate Success. New York: HarperBusiness.

and Ming-Jer Chen (1994), "Sources and Consequences of Competitive Inertia: A Study of the U.S. Airline Industry," Administrative Science Quarterly, 39, 1-23.

and Peter H. Friesen (1980), "Momentum and Revolution in Organizational Adaptation," Academy of Management Journal, 23 (4), 591-614.

and - (1984), "A Longitudinal Study of the Corporate Life Cycle," Management Science, 30, 1161-83.

Miller, Kent D. (1993), "Industry and Country Effects on Managers' Perceptions of Environmental Uncertainties," Journal of International Business Studies, 24 (4), 693 714.

Milliken, Frances J. (1987), "Three Types of Perceived Uncertainty About the Environment: State, Effect, and Response Uncertainty," Academy of Management Review, 12 (1), $133-43$.

and Luis L. Martins (1996), "Searching for Common Threads: Understanding the Multiple Effects of Diversity in Organizational Groups," Academy of Management Review, 21 (2), 402-33.

Miranda, Shaila M. and Carol Saunders (1995), "Group Support Systems: An Organization Development Intervention to Combat Groupthink," Public Administration Quarterly, 19 (2), 193-216.

Mohr, Jakki and Robert Spekman (1994), "Characteristics of Partnership Success: Partnership Attributes, Communication Behavior, and Conflict Resolution Techniques," Strategic Management Journal, 15 (2), 135-52. 
Montoya-Weiss, Mitzi and Roger J. Calantone (1994), "Determinants of New Product Performance: A Review and Meta-Analysis," Journal of Product Innovation Management, 11, 397-417.

Moorman, Christine (1995), “Organizational Market Information Process: Cultural Antecedents and New Product Outcomes," Journal of Marketing Research, 32 (May), $318-35$

and Anne S. Miner (1997), "The Impact of Organizational Memory on New Product Performance and Creativity," Journal of Marketing Research, 34 (February), 91-106.

and Roland T. Rust (1999), "The Role of Marketing," Journal of Marketing, 63 (Special Issue), 180-97.

Morgan, R.E., C.S. Katsikeas, and K. Appiah-Adu (1998), "Market Orientation and Organizational Learning Capabilities," Journal of Marketing Management, 14, 353 81.

Morris, M.H. and G.W. Paul (1987), “The Relationship Between Entrepreneurship and Marketing in Established Firms," Journal of Business Venturing, 2, 247-59.

Nakata, K. and K. Sivakumar (1996), "National Culture and New Product Development: An Integrative Review," Journal of Marketing, 60 (January), 61-72.

Narver, J.C. and S.F. Slater (1990), "The Effect of a Market Orientation on Business Profitability," Journal of Marketing, 54 (October), 20-35.

Narver, J., S.F. Slater, and B. Tietje (1998), “Creating a Market Orientation,” Journal of Market-Focused Management, 2, 241-55.

Nelson, R.R. and S.G. Winter (1982), An Evolutionary Theory of Economic Change. Cambridge, MA: Belknap Press.

Nerkar, Atul and Peter W. Roberts (2004), "Technological and Product-Market Experience and the Success of New Product Introductions in the Pharmaceutical Industry," Strategic Management Journal, 25, 779-99.

Neuman, W.L. (1994), Social Research Methods: Qualitative and Quantitative Approaches. Boston: Allyn \& Bacon. 
Noble, C.H., R.K. Sinha, and A. Kumar (2002), "Market Orientation and Alternative Strategic Orientation: A Longitudinal Assessment of Performance Implications," Journal of Marketing, 66 (October), 24-39.

O'Cass, Aron (2001a), "The Internal-External Marketing Orientation of A Political Party: Social Implications of Political Party Marketing Orientation," Journal of Public Affairs, 1 (2), 136-52.

(2001b), "Political Marketing: An Investigation of the Political Marketing Concept and Political Market Orientation in Australian Politics," European Journal of Marketing, 35 (9-10), 1003-25.

O'Connor, Gina Colarelli (1998), "Market Learning and Radical Innovation: A Cross Case Comparison of Eight Radical Innovation Projects," Journal of Product Innovation Management, 15, 151-66.

O’Driscoll, Aidan, David Carson, and Audrey Gilmore (2001), "The Competence Trap: Exploring Issues in Winning and Sustaining Core Competence," Irish Journal of Management, 22 (1), 73-90.

Olson, Eric M., O.C. Walker, and Robert W Ruekert (1995), "Organizing for Effective New Product Development: The Moderating Role of Product Innovativeness," Journal of Marketing, 59 (January), 48-62.

Orton, J.D. and K.E. Weick (1990), "Loosely Coupled Systems: A Reconceptualization," Academy of Management Review, 15 (2), 203-23.

Pelham, Alfred M. (1997a), "Mediating Influences on the Relationship Between Market Orientation and Profitability in Small Industrial Firms," Journal of Marketing Theory and Practice, 5 (3), 55-76.

(1997b), "Market Orientation and Performance: the Moderating Effects of Product and Customer Differentiation," The Journal of Business \& Industrial Marketing, 12 (5), 276-97. and D.T. Wilson (1996), "A Longitudinal Study of the Impact of Market Structure, Firm Structure, Strategy, and Market Orientation Culture on Dimensions of SmallFirm Performance," Journal of the Academy of Marketing Science, 24 (1), 27-43.

Penrose, E.T. (1959), The Theory of the Growth of the Firm. New York: John Wiley \& Sons. 
Perry, Monica L. and Alen T. Shao (2002), "Market Orientation and Incumbent Performance in Dynamic Market," European Journal of Marketing, 36 (9-10), 1140-53.

Pitt, Leyland, Albert Caruana, and Pierre R. Berthon (1996), "Market Orientation and Business Performance: Some European Evidence," International Marketing Review, $13(1), 5-18$.

Porter, Michael E. (1980), Competitive Strategy: Techniques for Analyzing Industries and Competitors. New York: Free Press.

Powell, Walter W. (1990), "Neither Market nor Hierarchy: Network Forms of Organization," Research in Organizational Behavior, 12, 295-336.

— Kenneth W. Koput, and Laurel Smith-Doerr (1996), "Interorganizational Collaboration and the Locus of Innovation: Networks of Learning in Biotechnology," Administrative Science Quarterly, 41 (1), 116-45.

Pulendran, Sue, Richard Speed, and Robert E. Widing II (2003), "Marketing Planning, Market Orientation and Business Performance," European Journal of Marketing, 37 (3-4), 467-97.

Quinn, J.B. (1980), Strategies for Change: Logical Incrementalism. Homewood, IL: Richard D. Irwin.

Rajagopalan, N. and G.M. Spreitzer (1996), "Toward a Theory of Strategic Change: A MultiLens Perspective and Integrative Framework," Academy of Management Review, 22 (1), 48-79.

Raju, P.S. and Subhash C. Lonial (2001), "The Impact of Quality Context and Market Orientation on Organizational Performance in a Service Environment," Journal of Service Research, 4 (2), 140-54.

Reagans, Ray and Bill McEvily (2003), "Network Structure and Knowledge Transfer: The Effects of Cohesion and Range," Administrative Science Quarterly, 48 (2), 240-67.

Richard, Orlando C., Tim Barnett, Sean Dwyer, and Ken Chadwick (2004), "Cultural Diversity in Management, Firm Performance, and the Moderating Role of Entrepreneurial Orientation Dimensions," Academy of Management Journal, 47 (2), $255-66$. 
Rindfleisch, Aric and Christine Moorman (2001), "The Acquisition and Utilization of Information in New Product Alliances: A Strength-of-Ties Perspective," Journal of Marketing, 65 (April), 1-18.

Roberts, E.B. (1988), "What We've Learned Managing Invention and Innovation," Research Technology Management, 31 (1), 11-29.

Romanelli, Elaine and Michael L. Tushman (1994), "Organizational Transformation As Punctuated Equilibrium: An Empirical Test," Academy of Management Journal, 37 (5), 1141-66.

Rousseau, D.M. (1978), "Characteristics of Departments, Positions, and Individuals: Contexts for Attitudes and Behavior," Administrative Science Quarterly, 23 (4), 52140.

Rowley, Tim, Dean Behrens, and David Krackhardt (2000), "Redundant Governance Structures: An Analysis of Structural and Relational Embeddedness in the Steel and Semiconductor Industries," Strategic Management Journal, 21, 369-86.

Ruekert, Robert W. (1992), "Developing a Market Orientation: An Organizational Strategy Perspective," International Journal of Research in Marketing, 9, 225-45. and Orville C. Walker Jr. (1987), "Marketing's Interaction with Other Functional Units: A Conceptual Framework and Empirical Evidence," Journal of Marketing, 51 (January), 1-19.

— _ _ and Kenneth J. Roering (1985), "The Organization of Marketing Activities: A Contingency Theory of Structure and Performance," Journal of Marketing, 49 (January), 13-25.

Sakavou, H., G. Baltas, and S. Lioukas (2004), "Organisational Innovation in SMEs: The Importance of Strategic Orientation and Competitive Structure," European Journal of Marketing, 38 (9-10), 1091-1112.

Sarin, Shikhar and Christopher McDermott (2003), "The Effect of Team Leader Characteristics on Learning, Knowledge Application, and Performance of CrossFunctional New Product Development Teams," Decision Sciences, 34 (4), 707-39.

Sawyerr, Olukemi O. (1993), "Environmental Uncertainty and Environmental Scanning Activities of Nigerian Manufacturing Executives: A Comparative Analysis," Strategic Management Journal, 14, 287-99. 
Schulz, M. (2001), “The Uncertain Relevance of Newness: Organizational Learning and Knowledge Flows," Academy of Management Journal, 44 (4), 661-81.

Schumpeter, J.A. (1934), The Theory of Economic Development. Cambridge, MA: Harvard University Press.

Sekaran, U. (1992), Research Methods for Business: A Skill Building Approach. New York: John Wiley \& Sons.

Senge, P.M. (1990), The Fifth Discipline: The Art and Practice of the Learning Organization. New York: Doubleday.

Sethi, Rajesh, Daniel C. Smith, and C. Whan Park (2001), "Cross-Functional Product Development Teams, Creativity, and the Innovativeness of New Consumer Products," Journal of Marketing Research, 38 (February), 73-85.

Shapiro, Benson P. (1988), "What the Hell Is 'Market Oriented'?, " Harvard Business Review, 66 (6), 119-125.

Sharfman, M.P. and J.W. Dean (1997), “The Effects of Context on Strategic Decision Making Processes and Outcomes," in Strategic Decisions, V. Papadakis and P. Barwise, eds. Boston: Kluwer Academic Publishers.

Sharma, P. and J.J. Chrisman (1999), "Toward a Reconciliation of the Definitional Issues in the Field of Corporate Entrepreneurship," Entrepreneurship Theory and Practice, 23 (3), 11-27.

Siguaw, Judy A., Gene Brown, and Robert E. Widing II (1994), "The Influence of the Market Orientation of the Firm on Sales Force Behavior and Attitudes," Journal of Marketing Research, 31 (February), 106-16.

and A. Diamantopoulos (1995), "Measuring Market Orientation: Some Evidence on Narver and Slater's Three Component Scale," Journal of Strategic Marketing, 3, 7788.

— Orientation on Distributor Market Orientation and the Channel Relationship: The Distributor Perspective," Journal of Marketing, 62 (July), 99-111.

Sin, Leo Y.M., Alen C.B. Tse, Oliver H.M. Yau, Raymond Chow, and Jenny S.Y. Lee (2003), "Market Orientation and Business Performance: A Comparative Study of 
Firms in Mainland China and Hong Kong," European Journal of Marketing, 37 (56), 910-36.
$-\frac{-}{-},-\frac{}{-}$, and - (2005), "Market Orientation, Relationship Marketing Orientation, and Business Performance: The Moderating Effects of Economic Ideology and Industry Type.," Journal of International Marketing, 13 (1), $36-57$.

Sinkula, J.M. (1994), "Market Information Processing and Organizational Learning,” Journal of Marketing, 58 (January), 34-45.

_ (2002), "Market-Based Success, Organizational Routines, and Unlearning," Journal of Business and Industrial Marketing, 17 (4), 253-69.
— W. E. Baker, and T. Noordewier (1997), “A Framework for Market-Based Organizational Learning: Linking Values, Knowledge, and Behavior," Journal of the Academy of Marketing Science, 25 (4), 305-18.

Sitkin, S.B., K.M. Sutcliffe, and R.G. Schroeder (1994), "Distinguishing Control from Learning in Total Quality Management: A Contingency Perspective," Academy of Management Review, 19 (3), 537-64.

Siu, N.Y.M. and R.M.S. Wilson (1998), "Modelling Market Orientation: An Application in the Education Sector," Journal of Marketing Management, 14 (4), 293-323.

Slater, Stanley F. and John C. Narver (1994), "Does Competitive Environment Moderate the Market Orientation-Performance Relationship?” Journal of Marketing, 46 (January), 46-55.

and - (1995), "Market Orientation and the Learning Organization," Journal of Marketing, 59 (July), 63-74.
— and - (1998), "Customer-Led and Market-Oriented: Let's Not Confuse the Two,” Strategic Management Journal, 19, 1001-6. and - (1999), "Market-Oriented Is More Than Being Customer-Led," Strategic Management Journal, 20, 1165-68.

and - (2000), "Intelligence Generation and Superior Customer Value," Journal of the Academy of Market Science, 28 (1), 120-27. 
Smith, P.G. and D.G. Reinertsen (1991), Developing Products in Half the Time. New York: Van Nostrand Reinhold.

Snow, Charles C. and James B. Thomas (1994), "Field Research Methods in Strategic Management: Contributions to Theory Building and Testing," Journal of Management Studies, 3 (4), 457-80.

Song, X. Michael and Mark E. Parry (1997), "A Cross-National Comparative Study of New Product Development Processes: Japan and the United States," Journal of Marketing, 61 (April), 1-18.

Song, X. Michael and Mitzi M. Montoya-Weiss (1998), "Critical Development Activities for Really New Versus Incremental Products," Journal of Product Innovation Management, 15, 124-35.

Sorescu, Alina, Rajesh K. Chandy, and Jaideep C. Prabhu (2003), "Sources and Financial Consequences of Radical Innovation: Insights from Pharmaceuticals," Journal of Marketing, 82 (October), 82-102.

Stan, Simona, Kenneth R. Evans, and Dan Cernusca (2000), "Collectivism and Market Orientation in a Privatizing Economy: An Exploratory Study of Retailing in Romania," Winter AMA Educators' Conference Proceedings, 11, 278-79.

Staw, Barry M. (1980), "The Escalation of Commitment to a Course of Action," Academy of Management Review, 6 (4), 577-87.

— L Lance E. Sandelands, and Jane E. Dutton (1981), "Threat Rigidity Effects in Organizational Behavior: A Multilevel Analysis," Administrative Science Quarterly, $26,501-24$.

Steinman, Christine, Rohit Deshpandé, and John U. Farley (2000), "Beyond Market Orientation: When Customers and Suppliers Disagree," Journal of the Academy of Market Science, 28 (1), 109-19.

Stinchcombe, Arthur L. (1986), "Reason and Rationality," Sociological Theory, 4 (fall), 15166.

Stopford, J.M. and C.W. Baden-Fuller (1994), "Creating Corporate Entrepreneurship," Strategic Management Journal, 15, 521-36. 
Suls, J.M. (1977), "Social Comparison Theory and Research: An Overview from 1954," in Social Comparison Processes: Theoretical and Empirical Perspectives, J.M. Suls and R.L. Miller, eds. Washington, DC Wiley-Halsted.

Szulanski, Gabriel (1996), "Exploring Internal Stickness: Impediments to the Transfer of Best Practice Within the Firm," Strategic Management Journal, 17, $27-43$.

Tadepalli, R. and R.A. Avila (1999), "Market Orientation and the Marketing Strategy Process," Journal of Marketing Theory and Practice, 7 (2), 69-82.

Tauber, Edward M. (1974), "How Marketing Discourages Major Innovation,” Business Horizons, 17 (June), 22-26.

Teece, David J. (1988), "Technological Change and the Nature of the Firm," in Technical Change and Economic Theory, Dosi Giovanni, Chistopher Freeman, Richard Nelson, Gerald Silverberg and Luc Soete, eds. London: Pinter Publishers.

_, Gary Pisano, and Amy Shuen (1997), "Dynamic Capabilities and Strategic Management," Strategic Management Journal, 18, 509-33.

Troy, Lisa C., David M. Szymanski, and P. Rajan Varadarajan (2001), "Generating New Product Ideas: An Initial Investigation of the Role of Market Information and Organizational Characteristics," Journal of the Academy of Market Science, 29 (1), 84-101.

Tsai, Wenpin (2001), "Knowledge Transfer in Intraorganizational Networks: Effects of Network Position and Absorptive Capacity on Business Unit Innovation and Performance," Academy of Management Journal, 44 (5), 996-1004. (2000), "Social Capital, Strategic Relatedness and the Formation of Intraorganizational Linkages," Strategic Management Journal, 21, 925-39.

Tushman, M.L. and P. Anderson (1986), "Technological Discontinuities and Organizational Environments," Administrative Science Quarterly, 31 (3), 439-65. and E. Romanelli (1985), "Organizational Evolution: A Metamorphosis Model of Convergence and Reorientation," in Research in Organizational Behavior, Vol. 7, L.L. Cummings and B. Staw, eds. Greenwich, CT: JAI Press.

Tyre, Marcie and Oscar Hauptman (1992), "Effectiveness of Organizational Responses to Technological Change in the Production Process," Organization Science, 3 (3), 30120. 
Van de Ven, Andrew H. (1986), "Central Problems in the Management of Innovation," Management Science, 32 (5), 590.

Varadarajan, P. Rajan and Satish Jayachandran (1999), "Marketing Strategy: An Assessment of the State of the Field and Outlook," Journal of Academy of Marketing Science, 27 (2), 120-43.

Vazquez, Rodolfo, Luis Ignacio Alvarez, and Maria Leticia Santos (2002), "Market Orientation and Social Services in Private Non-Profit Organisations," European Journal of Marketing, 36 (9-10), 1022-46.

Vecchio, R.P. (1982), “ A Further Test of Leadership Effects due to Between-Group Variation and Within-Group Variation," Journal of Applied Psychology, 67, 200-8.

Veryzer, Robert W., Jr. (1998), "Discontinuous Innovation and the New Product Development Process," The Journal of Product Innovation Management, 15 (4), 304 21.

von Hippel, Eric (1986), "Lead Users: A Source of Novel Product Concepts," Management Science, 32 (7), 791-805. (1989), “New Product Ideas From 'Lead Users'," Research Technology Management, 32 (3), 24-27.

(1994), “'Sticky Information' and the Locus of Problem Solving: Implications for Innovation," Management Science, 40 (4), 429-39.

(1998), "Economics of Product Development by Users: The Impact of 'Sticky' Local Information," Management Science, 44 (5), 629-44.

Vorhies, Douglas W. and Neil A. Morgan (2005), "Benchmarking Marketing Capabilities for Sustainable Competitive Advantage," Journal of Marketing, 69 (January), 80-94.

Voss, Christopher A., Par Ahlstrom, and Kate Blackmon (1997), "Benchmarking and Operational Performance: Some Empirical Results," International Journal of Operations \& Production Management, 17 (10), 1046-58.

Voss, Glenn B. and Zannie Giraud Voss (2000), "Strategic Orientation and Firm Performance in an Artistic Environment," Journal of Marketing, 64 (January), 67-83. 
Walker, Orville C., Jr., and Robert W. Ruekert (1987), "Marketing's Role in the Implementation of Business Strategies: A Critical Review and Conceptual Framework," Journal of Marketing, 51 (July), 15-33.

Webster, Frederick E., Jr. (1992), “The Changing Role of Marketing in the Corporation," Journal of Marketing, 56 (October), 1-16.

Wei, Yinghong (2004), "Congruence Between Market Orientation and Compensation Strategy: Implications for New Product Performance in a Transitional Economy," working paper.

and Neil A. Morgan (2004), "The Supportiveness of Organizational Climate, Market Orientation, and New Product Performance in Chinese Firms," Journal of Product Innovation Management, 21, 375-88.

Wiklund, Johan (1999), “The Sustainability of the Entrepreneurial Orientation-Performance Relationship," Entrepreneurship Theory and Practice, 24, 37-48.

and Dean Shepherd (2003), "Knowledge-Based Resources, Entrepreneurial Orientation, and the Performance of Small and Medium-Sized Business," Strategic Management Journal, 24, 1307-14.

Wind, Jerry and Vijay Mahajan (1997), "Issues and Opportunities in New Product Development: An Introduction to the Special Issue," Journal of Marketing Research, 34 (February), 1-12.

Wrenn, Bruce (1997), “The Market Orientation Construct: Measurement and Scaling Issues," Journal of Marketing Theory and Practice, 5 (summer), 31-54.

Wright, Benjamin (2000), “Technology File: Laws Guide Uniformity for E-signatures,” Credit Union Executive Journal, 40 (6), 17.

Wuyts, Stefan, Shantanu Dutta, and Stefan Stremersch (2004), "Portfolios of Interfirm Agreements in Technology-Intensive Markets: Consequences of Innovation and Profitability," Journal of Marketing, 68 (April), 88-100.

Yli-Renko, Helena, Erkko Autio, and Harry J. Sapienza (2001), "Social Capital, Knowledge Acquisition, and Knowledge Exploitation in Young Technology-Based Firms," Strategic Management Journal, 22, 587-613. 
Young, Gary J., Martin P. Charns, and Stephen M. Shortell (2001), “Top Manager and Network Effects on the Adoption of Innovative Management Practices: A Study of TQM in a Public Hospital System," Strategic Management Journal, 22, 935-51.

Zahra, Shaker A. (1993a), "Environment, Corporate Entrepreneurship and Company Performance: A Taxonomic Approach," Journal of Business Venturing, 8, 319-40. (1993b), "A Conceptual Model of Entrepreneurship As Firm Behavior: A Critique and Extension," Entrepreneurship Theory and Practice, 16, 5-21. and J.G. Covin (1995), "Contextual Influences on the Corporate EntrepreneurshipPerformance Relationship: A Longitudinal Analysis," Journal of Business Venturing, $10,43-58$.

__, Sarah Nash, and Deborah J. Bickford (1995), "Transforming Technological Pioneering into Competitive Advantage," Academy of Management Executive, 9 (February), 17-31.

Zaltman, Gerald, Karen LeMasters, and Michael Heffring (1982), Theory Construction in Marketing. New York: John Wiley \& Sons.

Zhou, Kevin Zheng, Chi Kin (Bennett) Yim, and David K. Tse (2005), "The Effects of Strategic Orientations on Technology- and Market-Based Breakthrough Innovations," Journal of Marketing, 69 (April), 42-60.

Zucker, Lynn G. (1977), "The Role of Institutionalization in Cultural Persistence," American Sociology Review, 42, 726-43. 